\title{
AVALIAÇÃO DA MEDIAÇÃO DE CONFLITOS NO CONTEXTO ESCOLAR: UM ESTUDO DE CASO NO DISTRITO FEDERAL
}

BÁRBARA SILVA DINIZ 


\title{
AVALIAÇÃO DA MEDIAÇÃO DE CONFLITOS NO CONTEXTO ESCOLAR: UM ESTUDO DE CASO NO DISTRITO FEDERAL
}

\author{
Dissertação de mestrado submetida ao Programa \\ de Pós-Graduação em Direitos Humanos e \\ Cidadania do Centro de Estudos Avançados \\ Interdisciplinares da Universidade de Brasília - \\ UNB como parte dos requisitos necessários para a \\ obtenção do Grau de Mestre em Direitos \\ Humanos e Cidadania. \\ Área de concentração: Educação em Direitos \\ Humanos e Cultura de Paz. \\ Orientadora: Dra. Vanessa Maria de Castro
}


Autorizo a reprodução e divulgação total ou parcial deste trabalho, por qualquer meio convencional ou eletrônico, para fins de estudo e pesquisa, desde que citada a fonte.

FICHA CATALOGRÁFICA

DINIZ, Bárbara Silva.

Avaliação de mediação de conflitos no contexto escolar: um estudo de caso no Distrito Federal. / Bárbara Silva Diniz. Orientadora Vanessa Maria de Castro. - Brasília, 2014. $249 f l$

Dissertação (Mestrado) - Universidade de Brasília, 2014.

Avaliação. Mediação de Conflitos. Escola. Direitos Humanos. 
Nome: DINIZ, Bárbara Silva.

Título: Avaliação da mediação de conflitos no contexto escolar: um estudo de caso no Distrito Federal

Dissertação de mestrado submetida ao Programa de PósGraduação em Direitos Humanos e Cidadania do Centro de Estudos Avançados Interdisciplinares da Universidade de Brasília - UNB como parte dos requisitos necessários para a obtenção do Grau de Mestre em Direitos Humanos e Cidadania

Aprovado em:

\section{BANCA EXAMINADORA}

Prof. Dra. Vanessa Maria de Castro - Universidade de Brasília

Prof. Dr. Cristovam Buarque - Universidade de Brasília

Prof. Dr. Wellington Lourenço de Almeida - Universidade de Brasília

Prof. Dra. Cleria Botelho da Costa - Universidade de Brasília (suplente) 
À Clarice 


\section{AGRADECIMENTOS}

O desenvolvimento deste trabalho só foi possível graças ao inestimável auxílio de diversas pessoas, em diversos âmbitos.

Dentro da Universidade de Brasília, um agradecimento especial à professora Dra. Vanessa Maria de Castro, minha orientadora, que tornou essa experiência prazerosa e gratificante, uma imersão num tema tão novo e o aprendizado do que, afinal, é pesquisa. Esse, de fato, foi um processo educativo em grande medida graças a ela.

À professora Nair Heloísa Bicalho de Sousa. Eu não teria condições de continuar no mestrado nem me dedicar como me dediquei se não fosse sua luta pela extensão das bolsas de estudo. Minha permanência no mestrado deu-se em razão disso.

A todos os integrantes do projeto de extensão e ação contínua "Estudar em Paz”, pelo seu apoio e colaboração.

Ao Daniel Barbosa, da Psicologia, por sua cordialidade, disposição e empenho em me auxiliar na tabulação dos dados. Eu só conheci o Iramutek, N’Vivo e o Alceste graças a sua atuação.

Agradeço ainda a todos os membros da escola pesquisada pelo acolhimento e disponibilidade para colaborar.

No âmbito pessoal, um grande, enorme, inestimável agradecimento a Ana Diniz, minha mãe, que revisou meus textos, discutiu comigo, auxiliou na construção dos instrumentos, na tabulação e na análise dos dados, e ainda por cima cuidou da Clarice enquanto eu trabalhava. Todo esse trabalho é, definitivamente, a quatro mãos.

Ao José Geraldo, pela sua infinita compreensão, seu senso de partilha, pelo companheirismo e por me apoiar em todos os sentidos nessa caminhada. Seria impossível sequer iniciar essa aventura se não fosse ele aceitando todos os encargos que isso representou, mesmo com as máquinas dessa modernidade fragmentada.

A D. Genoveva, que partilhou os cuidados de Clarice, deixando-me tranqüila para escrever esse trabalho. Ao meu pai, Adailton, meus irmãos, Diniz e Najara, meu sogro, José, e demais familiares e amigos, que partilharem de todo esse período.

Por fim, não poderia deixar de agradecer às pessoas anônimas e as instituições que organizam e tornam acessível a informação mundial na Internet. Muitas das obras, livros e artigos pesquisados só foram possíveis de ser acessados a partir dos sites de busca. Muito obrigada! 
A prática da violência, como toda ação, transforma o mundo, mas a transformação mais provável é em um mundo mais violento.

(ARENDT, 2004, p.51). 


\section{RESUMO}

O objetivo deste trabalho é avaliar o Projeto "Estudar em Paz: mediação de conflitos no contexto escolar", no período de 2010 a 20013, como uma ação de educação para os direitos humanos e uma cultura da paz. Os pressupostos teóricos que fundamentaram este trabalho foram Focault, Arendt e Weber, no que se refere à instituição escolar; Wieviorka, Charlot e Debarbieux quanto à violência no contexto escolar. Em relação à mediação de conflitos, adotou-se a posição da mediação social, de origem francesa, tendo-se como teóricos de trabalho Bush e Folger, Warat e Six. Esta avaliação caracterizou-se como um estudo de caso, pelo qual se buscou compreender o objeto estudado por meio da avaliação de sua implementação e de seus impactos numa escola do Distrito Federal. Para a construção dos dados fez-se uso de entrevistas, grupo focal e nota de campos bem como de pesquisa documental. Para análise e interpretação dos dados fez-se uso da análise de conteúdo, tendose o auxílio do software QSR N’Vivo ${ }^{\circledR}$ 10.0. Os resultados mostraram que o Projeto Estudar em Paz contempla uma proposta de educação para os direitos humanos e cultura de paz. $\mathrm{Na}$ escola pesquisada a formação em mediação social contribuiu para que os alunos participantes desenvolvessem habilidades para lidar de forma pacífica e dialogada com os conflitos e violências no contexto escolar e no cotidiano diário, bem como aumentou sua conscientização sobre as diversas violências, em especial as estruturais. No entanto, observou-se que o Projeto ainda encontra dificuldades para se efetivar como ação permanente dentro do sistema escolar.

\section{Palavras-chave: Avaliação. Mediação de Conflitos. Escola. Direitos Humanos.}




\begin{abstract}
This dissertation aims to evaluate the program "Estudar em Paz: mediação de conflitos no contexto escolar" (Study in Peace: conflict mediation in the school context) during the years 2010 to 2013, as educational program towards human rights and peace education. This research is based upon works of Focault, Arendt e Weber concerning the educational institution; of Wieviorka, Charlot e Debarbieux concerning violence in the school environment. Concerning the conflict mediation, the research worked with the concept of social mediation, which is of french origin, based upon the works of Bush and Folger, Six and Warat. This evaluation was characterized as a case study, as it aimed to comprehend the object of study evaluating its implementation and impact in one of the schools that implemented the project in the Brazilian Federal District. The research data was built through interviews, focus groups, field notes and documental research. To analyze and interpret the data, The analysis and interpretation of the research data was made by content analys, with the assistance of QSR N'Vivo 10.0 software. The results show that the "Estudar em Paz" program contemplates a proposal of educating towards human rights and a culture of peace. At school researched, the course of social conflicts mediation contributed to the development of skills for the students to deal peacefully and through dialogue with conflicts and violence in the school and daily routine as well increased their awareness of the various types of violence, especially structural violence. However, it was observed that the "Estudar em Paz" program still faces difficulties to be effective as a permanent action within the school system.
\end{abstract}

Key words: Evaluetion. Conflict Mediation. School. Human Rights. 


\section{LISTA DE TABELAS, GRÁFICOS e IMAGENS}

Tabela 1 - Percentual total de escolares frequentando o 9o ano do ensino fundamental por

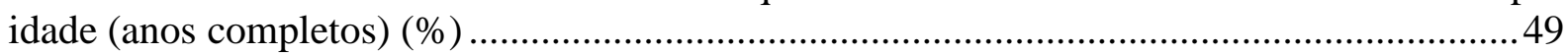

Tabela 2 - Comparativo da estimativa percentual por dependência administrativa com indicação do intervalo de confiança de $95 \%$ acerca da situação das escolas no Brasil............49

Tabela 3 - Comparativo da estimativa percentual por dependência administrativa com indicação do intervalo de confiança de $95 \%$ acerca da situação das escolas no Distrito Federal.

Tabela 4 - Como estudantes se sentem no ambiente escolar ................................................55

Tabela 5 - Vitimização de bullying e maus tratos, por frequência, duração e região................57

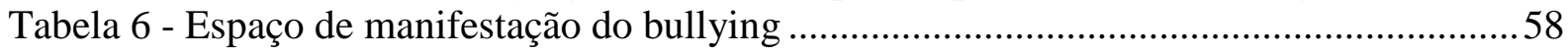

Tabela 7 - Fatores de risco para violência entre crianças e adolescentes .................................60

Tabela 8 - Quantitativo total e por segmento de entrevistados............................................. 106

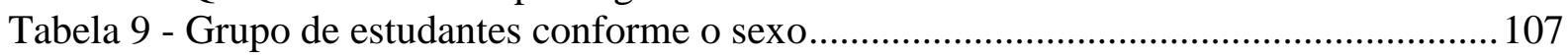

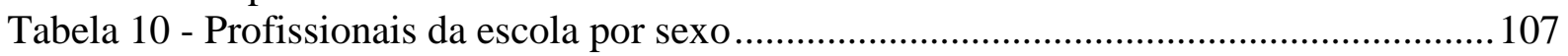

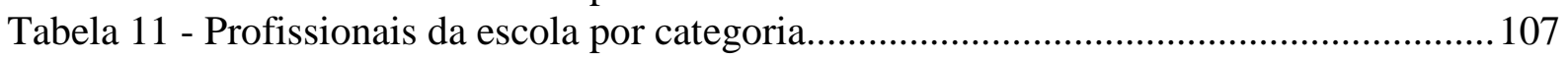

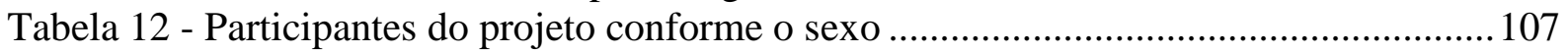

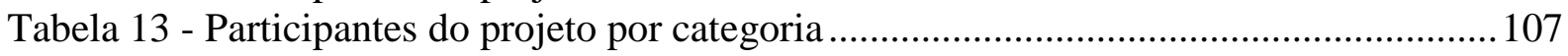

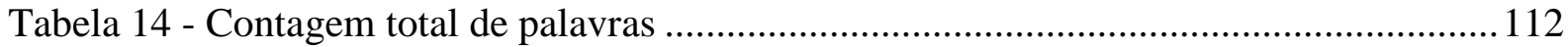

Tabela 15 - Situação do projeto ao final de 2013 em relação às escolas atendidas................. 120

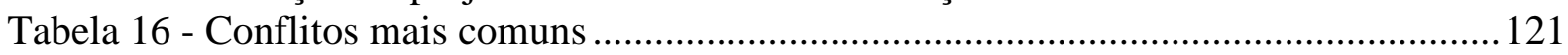

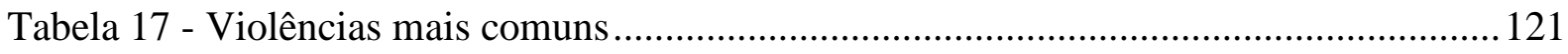

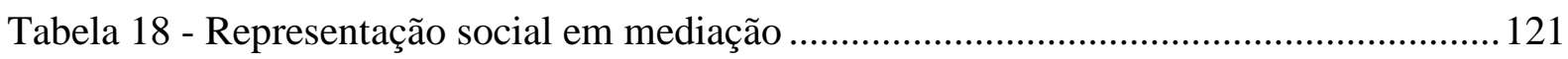

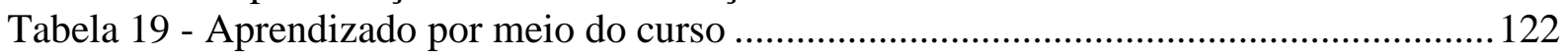

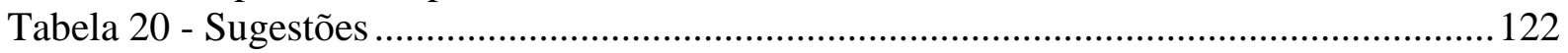

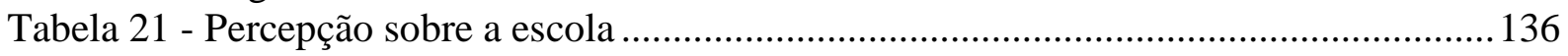

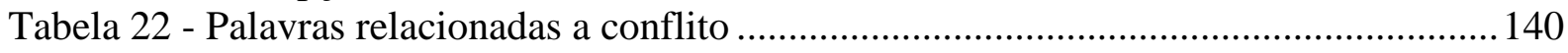

Tabela 23 - Dificuldades para a efetivação do Projeto ............................................................. 182

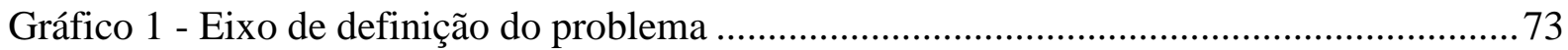

Gráfico 2 - Proporção do quantitativo total de entrevistados por segmento ........................... 106

Gráfico 3 - Gráfico nuvem apresentando as palavras de maior incidência ............................ 111

Gráfico 4 - Demonstração da proporção entre percepção positiva, negativa e intermediária 136

Gráfico 5 - Comparação entre a percepção de violência entre alunos e professor ................. 141

Imagem 1 - Classificação de famílias por grupos de vulnerabilidade social......................... 125 


\section{LISTA DE ABREVIATURAS E SIGLAS}

AC - Análise de Conteúdo

ADR - Alternative Dispute Resolution (práticas alterantivas de resolução de conflitos)

CCRC - Children's Creative Response to Conflitc

CDIS - Classe de Defasagem Idade-Série

CEAM - Centro de Estudos Avançados Multidisciplinares

CODEPLAN - Companhia de Planejamento do Distrito Federal

CRAS - Centro de Referência de Assistência Social

DEX - Decanato de Extensão

DIEESE - Departamento Intersindical de Estatística e Estudos Socioeconômicos

DIV - Delegação Interministerial para a Cidade (Délégation Interministérielle à la Ville

EDH - Educação para os Direitos Humanos

EJA - Educação de Jovens e Adultos

HSBC - Healthy Behavior in School Aged

IBGE - Instituto Brasileiro de Geografia e Estatística

IDH - Índice de Desenvolvimento Humano

NEP - Núcleo de Estudos para a Paz e os Direitos Humanos

OMS - Organização Mundial de Saúde

ONG - Organização não Governamental

PDAD - Pesquisa Distrital por Amostra de Domicílios

PEAC - Projeto de Extensão e Ação Contínua

PeNSE - Pesquisa Nacional de Saúde do Escolar

PMFC - Pró-Mulher, Família e Criança

PNDH - Plano Nacional de Direitos Humanos

PNEDH - Plano Nacional de Educação em Direitos Humanos

PNUD - Programa das Nações Unidas para o Desenvolvimento

PPP - Projeto Político Pedagógico

RA - Região Administrativa

TCLE - Termo de Consentimento Livre e Esclarecido

UCB - Universidade Católica de Brasília

UNB - Universidade de Brasília

UNESCO - Organização das Nações Unidas para a Educação, a Ciência e a Cultura ZUS - Zonas Urbanas Sensíveis 


\section{SUMÁRIO}

INTRODUÇÃO .........................................................................................................13

PARTE I - REFERENCIAL TEÓRICO...................................................................................... 18

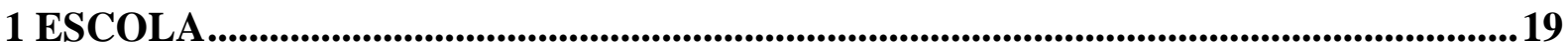

1.1 A instituição e a escola ...............................................................................................................21

1.2 A Educação ......................................................................................................................................23

1.3 Socialização ...............................................................................................................................2

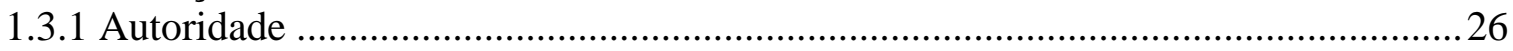

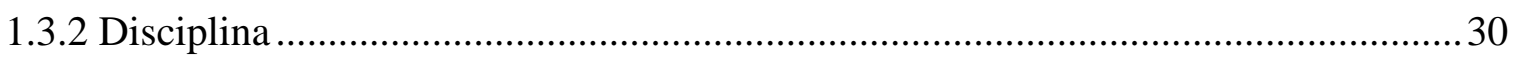

1.3.3 A escola dos paradoxos..........................................................................................

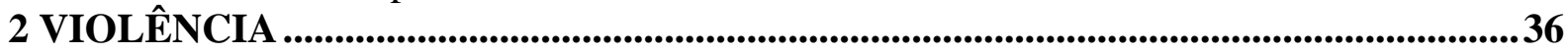

2.1. Concepções acerca da violência ...........................................................................................37

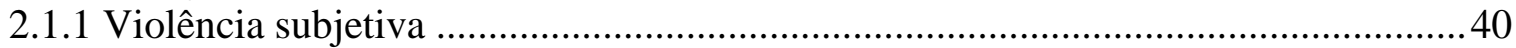

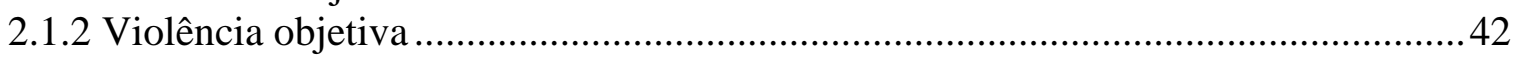

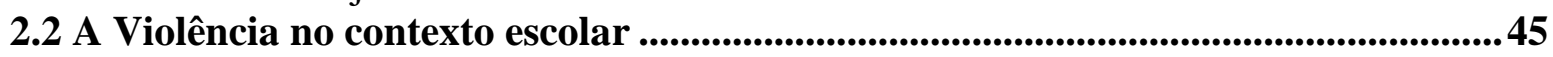

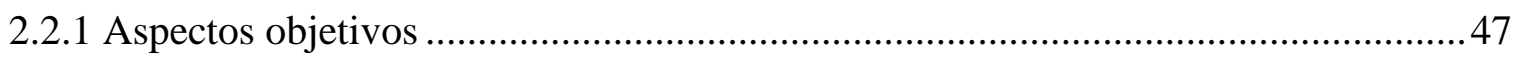

2.2.2 Aspectos subjetivos..................................................................................... 51

2.2.3 A convivência na escola...................................................................................54

2.4 Formas de prevenir e lidar com a violência no contexto escolar ...................................58

3 DO CONFLITO...................................................................................................................61

3.1 Uma concepção acerca do conflito.....................................................................62

3.2 Elementos e Dinâmica do Conflito.....................................................................................66

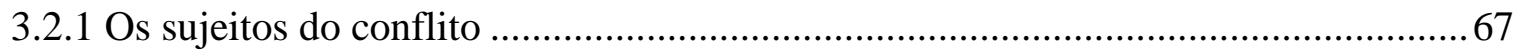

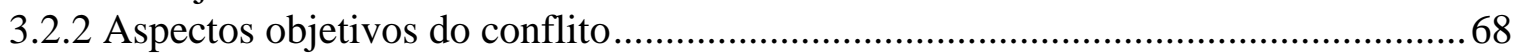

3.3 Conflito e Democracia...................................................................................................70

3.3 Transformação dos conflitos na escola........................................................................72

3.4.1 Educação para os direitos humanos (EDH) .........................................................73

4 MEDIAÇÃO DE CONFLITOS .....................................................................................................77

4.1 Mais uma história da mediação ................................................................................................78

4.2 Concepções.......................................................................................................................................83

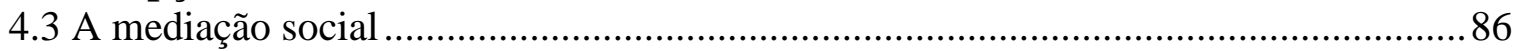

4.4 A mediação no contexto escolar ..........................................................................................89

PARTE II - ASPECTOS TEÓRICO-METODOLÓGICOS ................................................................94

5 ASPECTÓS TEÓRICO-METODOLÓGICOS.........................................................95

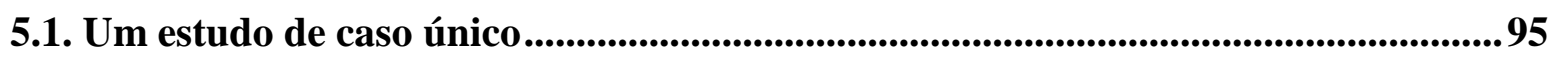

5.2 A geração dos dados ..........................................................................................97

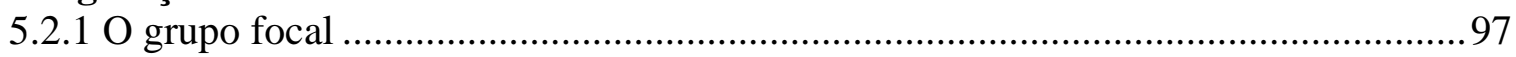

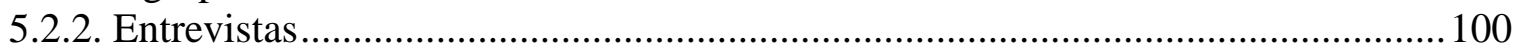

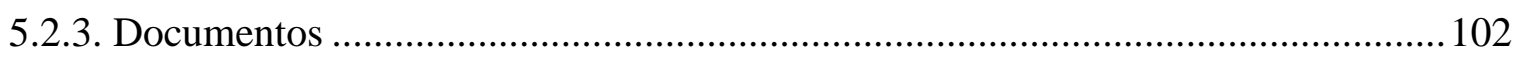

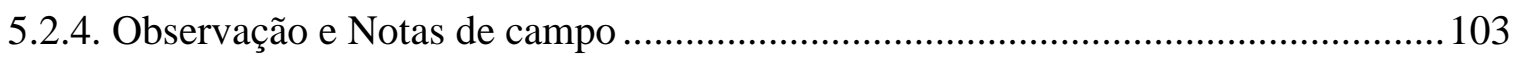

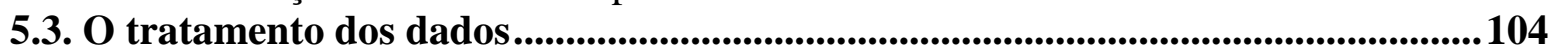

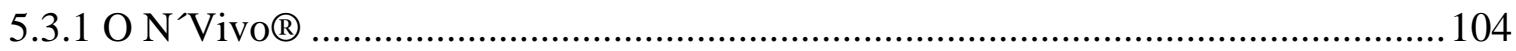

5.4. Qualidade política e ética...................................................................................................106

5.5. Apresentando o campo …..................................................................................108

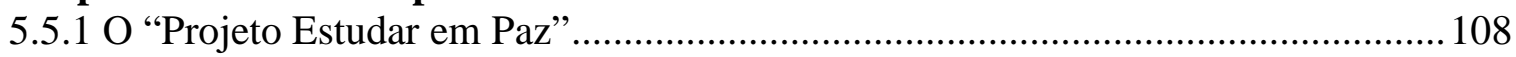

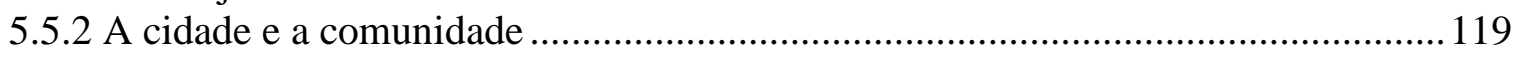

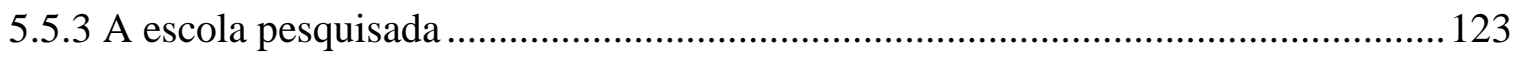


PARTE III -_ANÁLISE DOS DADOS E CONCLUSÃO ............................................................125

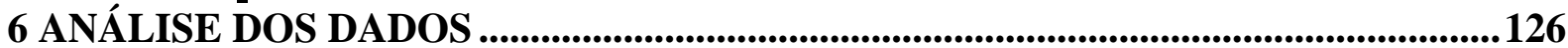

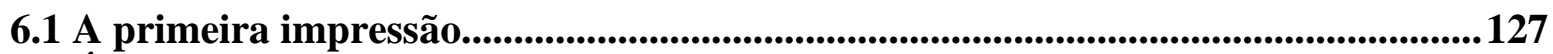

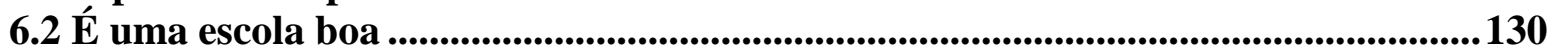

6.3 Conceitos gerais de conflito e de violência ................................................................... 133

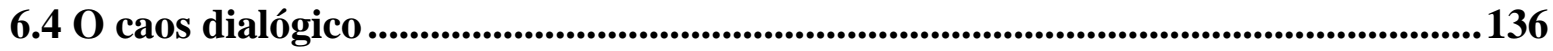

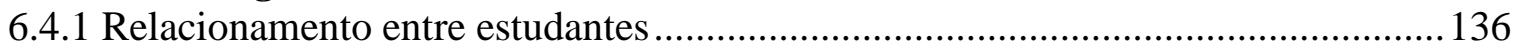

6.4.1.1 Começa com uma brincadeirinha e quando vê, vira um conflito ........................137

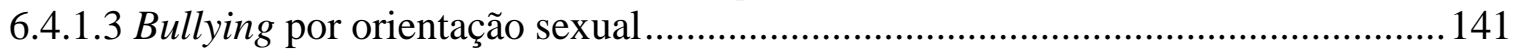

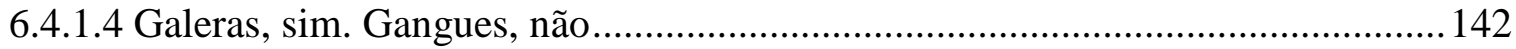

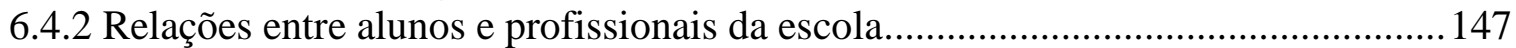

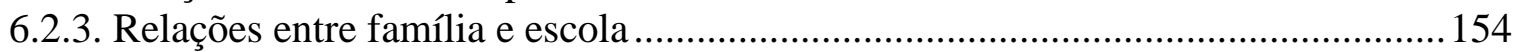

6.5 Violência? Tem muito não. Tem lá fora....................................................................... 156

6.5.3 O lanche é ruim, o banheiro é sujo e há falta de professor .................................... 161

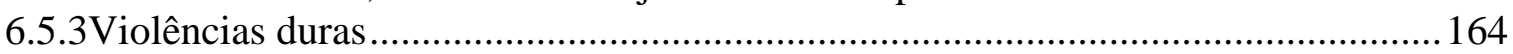

6.6 Uma escola que vigia, conversa e pune..............................................................167

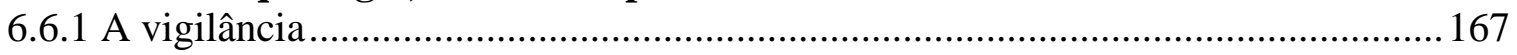

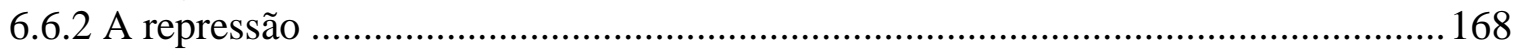

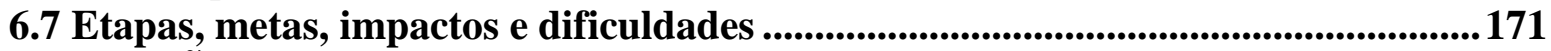

CONCLUSÃO

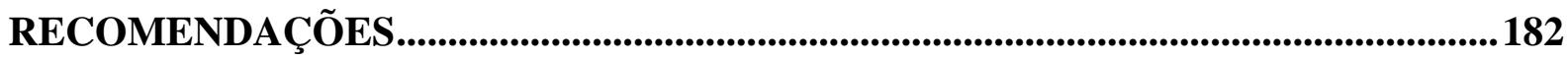

REFERÊNCIAS BIBLIOGRÁFICAS ..............................................................184

APENDICE A - ROTEIRO PARA GRUPO FOCAL ....................................................203

APÊNDICE B - ROTEIRO DE ENTREVISTA .............................................................204

ANEXO A - RELATÓRIO FINAL de COORDENADOR 2011 ...................................206

ANEXO B - RELATÓRIO FINAL de COORDENADOR 2012 .....................................217

ANEXO C - RELATÓRIO PARCIAL de COORDENADOR 2014...................................232 


\section{INTRODUÇÃO}

A relação entre direitos humanos e mediação de conflitos, para mim, sempre foi muito próxima. Eu já pensava nela mesmo antes de minha graduação em Direito, e nisso já se vão mais de 10 anos, tendo buscado atuar em conformidade com essa relação tanto na vida profissional quanto pessoal. Nesse sentido, a mediação, como processo de transformação de conflitos por meio do diálogo intermediado por um terceiro, era mais uma forma de luta e de conquista de direitos humanos, era uma técnica a mais junto aos movimentos sociais e também um modo de vida e de lidar com os conflitos do dia a dia.

Daí não haver me causado estranhamento quando fui convidada para, junto com uma amiga, apresentar uma oficina de mediação social e cidadania para alunos do ensino médio numa escola pública do Distrito Federal. Também não houve surpresa quando essa oficina transformou-se num curso de formação de mediadores sociais no contexto escolar e, mais tarde, já após meu afastamento dessas ações, no Projeto de Extensão e Ação Contínua da (PEAC) da Universidade de Brasília (UnB), vinculado ao Núcleo de Estudos para a Paz e os Direitos Humanos (NEP), que atua hoje em outras escolas públicas do Distrito Federal.

Se não houve surpresa, houve, porém, uma grande curiosidade de verificar essa relação empiricamente, em especial no contexto escolar. Foi aí que surgiu a oportunidade do mestrado em Direitos Humanos e Cidadania da UnB. Mas eis que um desafio a mais surgiu: a escola, a partir de então o meu locus de pesquisa, não tinha relação com minha área de formação inicial. Bem, a escola faz parte da minha vida como pessoa escolarizada que sou, porém não como conceito acadêmico, não como campo de estudo, de reflexão e de discussão.

Assim, enveredar por esse caminho e descobrir uma escola que, além de espaço de relações, de convivência e de educação formal, é um processo de formatação que se dá entre professor e aluno mediado por um currículo direcionado à ocupação de trabalhadores no sistema capitalista e à manutenção de um sistema de desigualdade e opressão (ILLICH, 1983. SHIPMAN, 1975) talvez tenha sido o grande desafio desse período. Isso porque ele permitiu aprofundar questionamentos que vinha fazendo parte de minhas reflexões acerca de nossa situação de seres humanos na modernidade.

Nesse sentido, esse processo de escolarização de massas, iniciado com as revoluções burguesas e intensificado após a II Guerra Mundial (MOSÉ, 2013; SHIPMAN, 1975), parece causar, ele próprio, parte das contradições do mundo atual, bem como é também por elas produzido. 
Assim, se a escola se coloca como um dos espaços de educação, vista essa como o processo de reflexão, de aprendizado, de aquisição e de produção de conhecimento no âmbito da vida, a chamada educação formal, ela também se coloca como espaço de crise.

Isso porque, por ser plural, a convivência aparece como uma questão do contexto escolar: como unir os mais diversos grupos étnicos, credos, orientações sexuais, num lugar ainda fundado sob as bases da autoridade e da disciplina num momento em que a sociedade como um todo expressa a quebra dessas relações em todas as suas instituições (ARENDT, 2013). Ou ainda como unir uma educação "de qualidade", o que quer que isso possa significar conforme as ideologias envolvidas, quando essa mesma "qualidade" pode ser influenciada pelas relações existentes dentro do âmbito escolar e mesmo pelo contexto social, principalmente quando considerados os aspectos da violência.

Violência, aqui, é qualquer ação que "deteriora ou destrói aquilo a que se aplica" (BLACKBURN, 1997, p. 405). Nesse sentido, e agora falando especificamente do Brasil, ela pode ser percebida, por exemplo, pelo número de mortes anuais por armas de fogo superior a de países em conflitos armados ou guerras declaradas ao redor do mundo (WEISELFISZ, 2014). No contexto escolar, por sua vez, pode envolver tanto a violência do entorno que ingressa na escola quanto a violência à escola (CHARLOT, 2002) ou ainda a violência da própria escola ao ser responsável pela reprodução de um sistema baseado no privilégio e na desigualdade (BOURDIEU, 1989. BOURDIEU e PASSERON, 1975).

Em qualquer contexto, pesquisas sobre o tema, desenvolvidas desde a década de 1980, mas principalmente após os anos 1990, indicam que "a violência tornou-se uma forma de comunicação urbana" (NJAINE e MINAYO, 2003, p. 121) e que a escola reflete essas violências no seu cotidiano.

Além disso, pesquisas como "Bullying escolar no Brasil" (FISCHER, 2010); "O que pensam os jovens de baixa renda sobre a escola pública" (TORRES et al. 2012), e a "Pesquisa Nacional de Saúde do Escolar" (BRASIL, 2013), apresentam a realidade da escola brasileira, em especial a pública, com um cotidiano repleto de violências (brigas, lesões corporais, porte de armas, ameaças), fragilidade de estudantes de escolas públicas em relação aos de escolas privadas, desorganização e insegurança escolar.

Outras pesquisas, por sua vez, indicam que essa violência diminui a proficiência de alunas e alunos em todas as disciplinas, refletindo diretamente na qualidade da atuação do professor no processo de ensino-aprendizagem (TEIXEIRA e KASSOUF, 2011; SEVERNINI, 2007; FISCHER, 2010). A UNESCO, por exemplo, desde 2003, apresenta dados sobre a percepção dos estudantes quanto aos efeitos da violência na escola: $45 \%$ não 
conseguem se concentrar nos estudos, $32 \%$ se sentem nervosos e $31 \%$ perderam o interesse em estudar (ABRAMOVAY, 2005). Esses dados são corroborados pelo Programme for International Student Assessment (Pisa) que, desde 2009, considera que salas de aulas com problemas disciplinares ensinam menos (BRASIL, 2011).

Enquanto isso, entre os desafios da educação brasileira está o de melhorar a proficiência de seus alunos. O país está na $55^{\mathrm{a}}$ posição em leitura, $58^{\mathrm{a}}$ em matemática e $59^{\circ}$ em ciências, tendo havido piora no ranking em relação a 2009 (BRASIL, 2012). Diante disso, é que em todas as metas estabelecidas no Plano Nacional de Educação (BRASIL, 2014) para a melhoria da educação estão previstas ações estratégicas que permitam o "combate à violência" a fim de estabelecer condições adequadas para o ensino e a aprendizagem.

Diante disso, surge a necessidade do estudo de ações que possam lidar com as violências e os conflitos no ambiente escolar, entre elas a mediação de conflitos.

A mediação de conflitos no contexto escolar não é um tema novo. Ela existe desde 1968 nos Estados Unidos. Desde então, já foi indicada pela UNESCO como estratégia educativa de prevenção da violência e de melhoria da convivência no contexto escolar (ORTEGA e DEL REY, 2002. JARES, 2002 e 2007).

Além disso, ela também integra as ações de políticas públicas, no Brasil, tanto no Plano Nacional de Direitos Humanos - 3 - (PNDH-3 - Objetivo Estratégico I, Diretriz n. 18, alínea e), como no Plano Nacional de Educação em Direitos Humanos (PNEDH).

Já no plano local o "Plano de (com)vivência escolar: construção em rede", política pública distrital intersetorial da Coordenação Educacional de Direitos Humanos $(\mathrm{COEDH})$, com o objetivo de construir medidas para enfrentamento de conflitos e de amparo às populações de risco ou de vulnerabilidade, prevê a instauração de núcleos de mediação de conflito nas escolas da rede pública de ensino (DISTRITO FEDERAL, 2012).

Assim, a existência da mediação de conflitos no contexto escolar é uma realidade, pelo menos desde as primeiras experiências registradas no Brasil, ainda em 2001. No Distrito Federal, uma das experiências, surgida em 2009, é o PEAC da UnB anteriormente mencionado nesta Introdução, chamado a partir de agora apenas de "Projeto Estudar em Paz".

O "Projeto Estudar em Paz" já foi implantado em cinco escolas no Distrito Federal entre 2009 e 2013 e, de acordo com a literatura acerca dele, vem demonstrando ser uma ferramenta eficaz na promoção de formas não violentas de se lidar com conflitos, com a conscientização das violências estruturais e com a melhoria das relações na escola. 
Diante disso, a pergunta orientadora deste estudo é: diante da realidade da violência na escola as ações desenvolvidas pelo "Projeto Estudar em Paz" podem contribuir para o desenvolvimento de uma cultura de paz e de direitos humanos?

Assim, o objetivo geral dessa pesquisa foi avaliar a implementação e os impactos do "Projeto Estudar em Paz" como uma ação de educação para os direitos humanos e cultura da paz em uma escola pública do Distrito Federal.

Como objetivos específicos foram enunciados:

a) analisar as relações entre escola, violência e conflito;

b) analisar os conflitos e as violências presentes no contexto escolar e encontrados pelo "Projeto Estudar em Paz";

c) analisar a mediação de conflitos como ferramenta de educação para os direitos humanos e uma cultura de paz no contexto escolar.

Cabe esclarecer, nesse ponto, que a proposta é usar a grafia "educação para os direitos humanos" (EDH) para enfatizar seu aspecto transversal e sua relação com o currículo oculto. Parte-se da concepção de que a vivência escolar deve ser ela mesma uma busca por uma cultura de direitos humanos, enfatizando-se a coerência entre meios e fins. Sabe-se que documentos oficiais, normativos e muitas das fontes pesquisadas para esse trabalho dão prioridade à expressão "educação em direitos humanos". Todavia, neste trabalho utilizou-se a enunciação dada Freire (2001), Claude (2005) e Bittar (2005).

Para atingir os objetivos da pesquisa, a dissertação encontra-se estruturada em três partes: referencial teórico, aspectos teórico-metodológicos e análise e conclusão.

A primeira parte é formada por quatro capítulos envolvendo os temas escola, violência, conflitos e mediação de conflitos.

No primeiro capítulo são apresentados os fundamentos nos quais se baseia a escola atual, como o poder disciplinar de Focault e a autoridade expressas por Arendt e Weber; sua função social, relacionada à educação formal, e o seu currículo oculto.

No capítulo dois a violência é apresentada como uma ação complexa, que deve ser compreendida tanto em seu aspecto subjetivo quanto objetivo e conforme o contexto histórico-social em que se encontra. No contexto escolar atual, é a reprodução de uma violência que perpassa toda a sociedade, daí a importância da contribuição de Arendt, Drawin, Wieviorka e Galtung, bem como, no contexto escolar, Bourdieu, Charlot e Derbabieux.

No capítulo três adota-se uma concepção de conflito como motor de mudança histórica e base para a democratização das instituições, tendo-se como aporte teórico pensadores antigos, como Lao Tzu e Heródoto, ou da idade moderna, como Maquiavel bem 
como Rancière, Lefort e Arendt. Utilizou-se, também como referência os estudos de Deutsch e Entelman dentro da teoria geral.

No quarto capítulo, com base nos estudos de Bush e Folger, Six e Warat, a mediação de conflitos se apresenta como uma ferramenta para lidar com os conflitos interpessoais e de transformação social, fortalecimento de grupos e comunidades e promoção dos direitos humanos.

A segunda parte do trabalho refere-se aos aspectos teórico-metodológicos, no qual são descritas as escolhas realizadas ao longo da pesquisa e é apresentado o campo. Apresentam-se ainda os motivos de escolha de uma abordagem qualitativa, do estudo de caso único (YIN, 2001) e da triangulação (BELL, 2004), estruturada em grupo focal, entrevistas semi-estruturadas, pesquisa documental bem como observação e notas de campo, além da forma de tratamento dos dados, que teve o auxílio do software N’Vivo 10.0. Também é nesse capítulo que as questões éticas são explicitadas, em especial quanto ao sigilo de identificação dos entrevistados, da escola pesquisada e mesmo da Região Administrativa (RA) onde essa se localiza. Diante disso, cabe adiantar que todos os nomes mencionados ao longo do trabalho são pseudônimos escolhidos aleatoriamente.

Por fim, a terceira parte consta da análise e discussão dos achados e a conclusão, contando ainda recomendações e sugestões. Em relação à análise, são feitas correlações dos achados com outras pesquisas referentes aos temas estudados, conforme o referencial teórico deste trabalho. 
PARTE I -

REFERENCIAL TEÓRICO 


\section{ESCOLA}

Para compreender e avaliar o "Projeto Estudar em Paz" foi necessário antes compreender o seu locus de atuação: a escola. Assim, as questões que me levaram ao longo deste capítulo foram: compreender que escola é essa, qual o currículo escolar e como ele se relaciona na formação para uma cultura de paz e de direitos humanos na atualidade.

Daí minha busca haver iniciado por sua etimologia, havendo, com surpresa, verificado que sua origem, do grego skholê, conforme o Dicionário Etimológico (2012), relaciona-se ao descanso, ao repouso, ao lazer, enfim, ao prazer. Tal concepção não pareceu ser a ideia que a escola traz hoje, principalmente quando me encontrei diante das minhas próprias lembranças e dos relatos qui fui ouvindo e apreendendo ao longo do mestrado.

Apesar desse princípio relaciodo com o prazer e a pluralidade essa escola inicial surge de uma sociedade dividida e desigual. Ou seja, esse espaço de pluralidade só surgiu quando um grupo de pessoas, em razão do seu trabalho, seja como escravo, seja como servo, libera um outro grupo para que, esse sim, possa usufruir da skholê (CÂNDIDO, 1977. AZEVEDO, 1977. SAVIANI).

Nesse sentido, a escola é, originalmente, um espaço elitizado (SAVIANI, 2005. OTTAWAY, 1962), de forma que me pareceu inicialmente difícil pensar numa continuidade temporal. Isso porque a escola que hoje existe, onde se desenvolve a educação formal, massificada, não é a mesma skholê. Mas em que momento houve essa dissociação?

Durante toda a idade antiga, entre diversos povos, a escola foi um local de pluralidade direcionado à elite. Na idade média, contudo, surgiu a universidade:

[...] uma zona franca para descobrir e discutir idéias novas e velhas. Mestres e alunos se reuniam para ler textos de outros mestres, já de há muito tempo mortos; as palavras vivas dos mestres falecidos traziam novas perspectivas aos sofismas de então. A universidade era, pois, uma comunidade de pesquisa acadêmica e inquietude endêmica (ILICH, 1985, p. 49).

É fato que a universidade não é uma escola. Assim como não é a skholê, mas ela integra o processo histórico de formação da escola da atualidade ao se constituir numa experiência anterior de educação formal, ainda que apenas para adultos. A escolarização de jovens e de crianças, por sua vez, surge na idade moderna, com a Companhia de Jesus. Isso não significa que não existissem antes escolas secundárias ou instrução infantil. A instrução existia dentro de processos informais do cotidiano, nas relações com os mais velhos, tendo as escolas infantis surgido já no século XII (ILLICH, 1985. SAVIANI, 2005). 
Contudo, é com o ensino jesuíta, da Contra Reforma, que o padrão do ensino escolar (um professor e vários alunos, organizados conforme seu conhecimento em uma sala de aula, em função da matéria a ser ensinada) se institucionaliza dentro de uma proposta de alfabetizar para o desenvolvimento moral e religioso. Ler e escrever eram secundários, necessários apenas na medida em que permitiam o objetivo principal: moralizar (TEIXEIRA, 1956. SHIPMAN, 1975. RIBEIRO, 1977. BASTOS, 1997). É então que escola perde seu caráter de espaço de prazer e passa a se relacionar à religião e à autoridade tradicional.

Com as revoluções dos séculos XVIII surge a concepção de uma escola estatal, laica, voltada às massas e com foco na criança. Até então a infância era compreendida apenas dentro de um aspecto de fragilidade: as crianças eram adultos em miniaturas, mais frágeis, mas sem processos de pensamento ou moral diferenciados (SINGER, 2010). Rousseau (1995) muda essa concepção ao considerar que a infância possui processos próprios que podem ser condicionados para a construção de uma nova sociedade. Daí a importância de a educação ser voltada para pessoas mais jovens.

A obra de Rousseau, que critica diretamente o antigo regime e suas instituições, entre elas a escolar, influencia o sistema educacional francês pós-revolução (PAIVA, 2011). Contudo, ao invés de uma educação voltada à autonomia, como desejava Rousseau (1975), a escola é instituída no ideal do mestre que leva ao ignorante o saber:

Fazendo passar os conhecimentos que possui para o cérebro daquele que os
ignoram, segundo uma sábia progressão adaptada ao nível das inteligências
limitadas, o mestre era, ao mesmo tempo, um paradigma filosófico e o agente
prático da entrada do povo na sociedade e na ordem governamental moderna. Esse
paradigma pode servir para pedagogos mais ou menos rígidos, ou para liberais. Mas
estas diferenças não desmerecem em nada a lógica do conjunto do modelo, que
atribui ao ensino a tarefa de reduzir tanto quanto possível a desigualdade social,
reduzindo a distância entre os ignorantes e o saber (RANCIÈRE, 2005, p. 11).

Assim, a escola surge como um local de desigualdade, com a função de treinamento moral com a finalidade de acabar com a revolução e transformar as instituições do antigo regime (RANCIÈRE, 2005. TEIXEIRA, 1956).

Com a Revolução Industrial a escola torna-se um espaço de instrução técnica e científica a fim de formar trabalhadores para a sociedade industrial. Daí ser essencial que a juventude soubesse ler, escrever e que estivesse adaptada ao trabalho hierarquizado e segmentado das fábricas (MOSÉ, 2013. RANCIÈRE, 2005. SHIPMAN, 1975). Surge, então, a escola com a instituição da modernidade.

Para tanto, foi fundamental o método desenvolvido em 1827, pelo quaker inglês Joseph Lancaster (RIBEIRO, 1977), voltado a uma rápida escolarização, mesmo com poucos professores. Por meio da autoridade e da disciplina, um único professor, sob um 
estrado, poderia supervisionar centenas de alunos num único local (BASTOS, 1997).

Essa escola tem como objetivo a massificação da escolarização e se baseia em modelos religiosos e militares (FOCAULT, 1984). É ela que se efetiva nos países desenvolvidos após a II Guerra Mundial e depois da abertura democrática na América Latina. Em outras palavras, é essa a escola que se torna o "processo que requer assistência de tempo integral a um currículo obrigatório, em certa idade e com a presença de um professor" (ILLICH, 1985, p. 40), ou seja, o modelo da escola atual.

A ideia de uma escola como processo refere-se a uma concepção relacionada à historicidade e transitoriedade das instituições (ILLICH, 1985). A escola, como instituição, é um processo permanente de transformação, como verificado da skholè à escola atual.

\subsection{A instituição e a escola}

Derivada do latim institutionis, a palavra instituição possui uma variedade de significados, como "ato de instruir, de educar" e ainda "estruturas material e humana que serve à realização de ações de interesse social ou coletivo" (HOUAISS 2001, p.1267).

Dentro desse sentido Saviani (2005), Teixeira (1956), Cândido (1977) e Gentili (2009) mencionam a escola como instituição por ser um local de organização de pessoas, onde ocorrem relações e práticas humanas, tornadas rotineiras e criadas para satisfazer determinadas necessidades. Nas palavras de Saviani:

[...] a palavra "instituição" guarda a idéia comum de algo que não estava dado e que é criado, posto, organizado, constituído pelo homem [...] para atender a determinada necessidade humana, mas não qualquer necessidade. Trata-se de necessidade de caráter permanente (2005, p. 28).

A finalidade da instituição é a modelação da conduta humana, ou seja, "a programação da conduta individual imposta pela sociedade" (BERGER e BERGER, 1980, p 193). Focault (1999) também vai tratar a instituição como o locus em que se apresentam a distribuição e os mecanismos de relações de poder sobre o indivíduo que visam à adaptação do indivíduo à sociedade.

A instituição, assim, transforma o corpo em força útil e produtiva à sociedade e, portanto, submisso. Contudo, essa relação deve ocorrer sem que o poder exercido seja percebido "como poder de alguns sobre alguns, mas como reação imediata de todos em relação a cada um" (FOCAULT, 1999, p. 149) a fim de que as resistências sejam mínimas.

Nesse sentido, as instituições podem ser condicionantes de alienação que, no dizer de Castoriadis (1982), exprimem e sancionam uma estrutura de classe. Alienação, aqui, é fazer e realizar, tomar decisões e ser apenas conforme o determinado pelo Outro, no caso, a 
instituição, sem se considerar os reais desejos e anseios dos indivíduos.

Isso significa que as necessidades que fazem surgir a instituição não são exatamente as necessidades de quem é a ela submetido, no caso aqui o aluno, e sim as necessidades da própria instituição de definir, de forma rápida e sem questionamentos, o que fazer, como agir e de que forma alcançar seu objetivo (FOCAULT, 1984).

Para tanto, as instituições possuem certa autonomia na reprodução de suas condições de produção, (SAVIANI, 2005), o que significa que detêm força coercitiva, ou seja, poder de fazer com que o indivíduo haja de determinada forma, sob pena de repreensão moral. É o que Berger e Luckmann (1976) chamam de controle social. Contudo, elas não são imutáveis.

Por ser processo, toda instituição detém historicidade e muda constantemente. Ela é o resultado de processos difusos, de fatos históricos, das ações de inúmeros indivíduos (ILLICH, 1985. BERGER e LUCKMAN, 1976. SAVIANI, 2005). Todavia, tal mudança é para perpetuar suas funções: moldar o comportamento humano, realizando a socialização (BERGER e BERGER, 1980a) ou, conforme Saviani (2005), a educação.

Para a escola realizar tais funções é certo que um conjunto de condições deve ser criado, como métodos e técnicas, currículos e profissionais para mediar o processo de aprendizagem. Daí Illich (1985) considerar que a escola é formada pelos alunos e professores, cuja relação é permeada por um currículo ou pela prática pedagógica (MOSÉ, 2013).

A ideia de currículo, assim, não é apenas o que se ensina na escola, o programa oficial, como também "o ambiente escolar, a sala de aula e os tipos de relação que se dão nestes espaços" (SILVA, M.J.L 1996, sp). Nesse sentido, ele pode ser expresso como um terreno de tradição simbólica, relacionado a um processo de "produção e criação de sentidos, de significações, de sujeitos". Ele é "um terreno de produção e de política cultural, no qual os materiais existentes funcionam como matéria-prima de criação, recriação e, sobretudo, de contestação e transgressão" (MOREIRA e SILVA, 2002, p. 27). Para Illich (1985) é o próprio ritual de escolarização.

O currículo é, assim, o aspecto ideológico que permeia a relação entre alunos e professores, que varia no tempo e no espaço, conforme o momento histórico vivido, as lutas e as construções sociais que se fizerem. É a partir dele que se dá a apropriação dos conhecimentos sistematizados, das práticas e habilidades cognitivas, da percepção do mundo bem como a aquisição de modos de agir e as convicções que levam a um posicionamento frente às demandas cotidianas (LIBANEO, 1992 e SHIPMAN, 1975).

O currículo é, por isso, um espaço de luta de ideologias (MOREIRA e SILVA, 
2002), daí a possibilidade de mudança institucional e, até mesmo, social. É por meio dele que as funções e os objetivos da instituição escolar, expressos no controle e na formatação social desejada pela sociedade, são realizados. Para compreender esse processo, é necessário compreender o currículo da escola da atualidade, mas antes o próprio conceito de educação.

\subsection{A Educação}

A atividade educativa se dá nas mais diversas esferas da vida social (família, grupos, instituições educacionais), daí haver concepções plurais. Nesse sentido, por exemplo, pode-se encontrar uma concepção relacionada à transmissão de cultura, ideia compartilhada por Teixeira (1956) e Freire (1996), sendo cultura aqui o mundo contrário à natureza, o mundo humano.

Essa é também a ideia de Arendt (2013, p. 235) quando diz que, pela educação, os pais assumem "a responsabilidade, ao mesmo tempo, pela vida e desenvolvimento da criança e pela continuidade do mundo".

A educação também é vista como processo de socialização. Essa é a concepção encontrada, por exemplo, em Mannheim (1977, p. 89) ao considerar a educação como uma técnica social de formação "do tipo desejado de cidadão" e em Durkheim (1977), ao conceituar educação como a socialização das novas gerações:

\section{A educação é a ação exercida pelas gerações adultas sobre as gerações que não se encontram ainda preparadas para a vida social; tem por objeto suscitar $e$ desenvolver, na criança, certo número de estados físicos, intelectuais e morais, reclamados pela sociedade política no seu conjunto e pelo meio especial a que a criança, particularmente se destine (DURKHEIM, 1977, p. 42 - itálico no original).}

Há, porém, quem conceitue educação como o produto da escola. Nesse sentido, Harris (1979) considera educação as experiências de aprendizado sancionadas pelo Estado e transmitidas em espaços institucionalizados. Ou seja, é a chamada educação formal ou escolar, com objetivo de ministrar uma compreensão do mundo. Esse também parece ser o conceito apresentado por Gentili (2009) quando considera a escola o aparato social com objetivo de garantir a educação, essa vista como direito social.

Mesmo Russel (1956a. 1956b), que menciona duas acepções de educação, uma educação da vida, permanente, e outra a educação estatal, formal, considera que, no mundo atual, a educação é principalmente a ministrada pelo Estado, por meio dos funcionários públicos, os professores, nas escolas.

Tal concepção é comum, a ponto de Mannheim e Stwart (1977, p. 131) declararem que a instituição escolar leva as pessoas a crerem que "a educação deve equivaler 
às instituições que proporcionam instrução formal", e Illich (1985) considerar que a escola traz como consequência a ideia de que educação é o que dela advém.

Diante disso, de um lado, ao se relacionar educação à transmissão de cultura ou socialização, forma-se um conceito a partir apenas de seus objetivos, que não diz o que algo é, mas para que serve. De outro lado, há uma confusão entre educação e obtenção de graus escolares, ensino e aprendizagem, processo e substância. Daí Gribble (1970), a partir de uma concepção da filosofia, considerar educação sob outro ponto de vista: como processo que implica a realização de três critérios.

O primeiro é a realização de uma atividade valiosa em si mesma, isto é, sem um objetivo específico, como passar numa prova ou adquirir uma habilidade. A educação é uma atividade que é um fim em si mesmo, assim como a saúde, a paz ou a felicidade. Assim, não se transmuta em educação a simples escolarização para se atingir graus maiores de ensino, tal como fazer um ensino médio apenas para se alcançar o ensino superior.

Além disso, a educação se dá a partir de um relacionamento prévio com outras experiências, havendo uma correlação com maneiras diversas de compreender e experimentar o mundo. Em outras palavras, não existe processo educativo em meio à fragmentação e dissociação dos temas. Em tudo deve haver uma contextualização e uma correlação.

Por fim, os envolvidos no processo educacional consideram que ela vale a pena por si só e, por isso, sentem-se preocupados com seu desenvolvimento (GRIBBLE, 1980). Há, então, um processo natural de interesse e curiosidade do próprio educando, o que faz com que a educação possua sempre uma conotação positiva. É nesse sentido que Peters (1973, p. 45) conceitua educação como o processo de desenvolvimento de conhecimento e compreensão (the development to know ledge and understanting in people).

Tal conceito vai ao encontro do expresso no Plano Nacional de Educação em Direitos Humanos - PNEDH (BRASIL, 2007), no qual a educação é o processo de reflexão e aprendizado, aquisição e produção de conhecimento, que se dá em todas as dimensões da vida e que se chama formal quando ocorre na escola.

Diante disso, a educação não é transitória, limitada ao período escolar, mas permanente, surgindo como possibilidade de transformação e de mudança, de nós mesmos e do mundo (FREIRE, 1996). Ela é um processo individual, interno, mas realizado, em grande parte, na relação com o outro, o que significa que ela também possui senso político. Em outras palavras, o processo educativo que se dá também na escola, por meio de instrução e ensino, consiste na assimilação de conhecimentos e experiências acumulados pelas gerações anteriores. Contudo, tal processo "está condicionado pelas relações sociais em cujo interior se 
desenvolve; e as condições sociais, políticas e econômicas, aí existentes influenciam decisivamente o processo de ensino-aprendizagem" (LIBANEO, 1993, p. 24).

Assim, a escola pode ou não ser um local de educação, ainda que formal, de forma que ela só o será quando alcançar os pressupostos de Grimbble (1980) e Peters (1972) acima mencionados. Ainda assim, a escola também pode ser um espaço de socialização.

\subsection{Socialização}

Socialização é o "processo por meio do qual o indivíduo aprende a ser um membro da sociedade" (BERGER e BERGER, 1980a, p. 204). Durkheim (1977) relaciona-o ao aprendizado de hábitos e costumes. Assim, pode-se dizer que é o processo que se desenvolve a partir das experiências com o ambiente e o outro, com fim de adaptação social.

A socialização, para Berger e Berger (1980a, p. 205), é a forma que uma criança tem de se desenvolver e expandir a fim de atingir a plena realização de seu potencial.

Focault (1984), por outro lado, trabalha o termo socializar e (ou) socialização em relação com o que se torna social, coletivo, responsável pela coletividade, mas que se dá por meio do controle sobre os indivíduos, por meio da consciência, da ideologia e também do corpo. O objetivo, no caso, ao integrar o indivíduo à sociedade, é tornar corpos e mentes dóceis e capazes de obedecer, sem resistência, em razão de um poder que se manifesta como uma reação imediata de todos contra um. É, então, um processo contínuo de alienação.

Qualquer que seja o caso, esse processo não é passivo. É, ao contrário, ativo e complexo, integrando todos os elementos presentes no ambiente, inclusive o sujeito à socialização. Nas palavras de Berger e Berger (1980):

[...] a socialização é um processo de configuração ou moldagem. A criança é configurada pela sociedade, e por ela moldada de forma a fazer dela um membro reconhecido e participante. Mas é importante que não se veja nisso um processo unilateral. Mesmo no início da vida, a criança não é uma vítima passiva da socialização. Resiste à mesma, dela participa e nela colabora de forma variada. A socialização é um processo recíproco, visto que afeta não apenas o indivíduo socializado, mas também os socializantes (BERGER E BERGER, 1980, p. 206).

Assim, a resistência, manifestada na escola pela desobediência de estudantes, integra o processo de socialização. Por isso, na modernidade, tal processo tem se dado de forma cada vez mais sutil, a fim de diminuir aquelas e facilitar a adaptação social. O que não significa, porém, que resistências não existam (FOCAULT, 1999 e 1984).

Dessa forma, a socialização não é uma via de mão única, uma imposição de um sistema sob um indivíduo solitário. É um processo que não é nem homogêneo nem massificado plenamente, mas relacionado às diversas experiências e relações sociais pelas 
quais cada indivíduo passa ao longo da vida. Daí ela também ser um permanente, ocorrendo em diversas instituições, como a família, a religião, a mídia ou a escola.

Ao permear diversas instituições, a socialização pode ocorrer por meio de valores contraditórios entre si. Ou seja, certas instituições podem transmitir valores não compartilhados pelas demais, gerando rejeição nos indivíduos a ela submetidos e maior capacidade de resistência (SHIPMAN, 1975. FOCAULT, 1984).

Assim, se a socialização é um processo de alienação, de produção de docilidade e de obediência, ou se, ao contrário, direciona-se à autonomia, isto é, à capacidade de o indivíduo perceber o que é verdadeiro, quais são seus desejos e suas reais aspirações (CASTORIADIS, 1982), enfim, se ela enseja mais ou menos resistências, vai depender das lutas ideológicas travadas dentro de cada instituição e, no caso da escola, de seu currículo (ILLICH, 1985. MOREIRA e SILVA, 2002).

$\mathrm{Na}$ atualidade, o currículo escolar reflete uma sociedade moderna, urbana, industrial, baseada na necessidade de trabalho segmentado, em larga escala e desigual, isto é, estruturada em classes e em prestígio (SHIPMAN, 1975). Nesse sentido, é um espaço marcado pela necessidade de obediência por meio da autoridade e do poder disciplinar, dois fundamentos sobre os quais se comentará a seguir.

\subsubsection{Autoridade}

A autoridade é a capacidade de se fazer obedecido de forma voluntária, a partir da percepção de quem se submete de que há algum tipo de legitimidade. Tal concepção é compartilhada por Blackburn (1997) e Stoppino (1995), para quem autoridade é o poder legítimo, com base em um sistema de normas prévias que afirma e aceita essa mesma autoridade. Pensamento também presente em Weber (2004) e Arendt (2013).

Peters (1973), por outro lado, conceitua a autoridade como o simples poder que alguém tem de dizer o que e como devemos fazer ou agir. Nesse sentido, não há uma base de legitimação desse poder, salvo a necessidade de convivência social e o fato de que as sociedades humanas, com maior ou menor intensidade, baseiam-se em relações de autoridade.

No entanto, esse conceito, ao enfatizar a obediência em detrimento da legitimidade, desconsidera que as relações de desigualdade nas sociedades humanas podem se fundar em diversos aspectos: na coação, na violência, na tradição ou mesmo no carisma do líder que é alçado ao posto de autoridade.

Contudo, Arendt (2013) salienta que coação ou violência não devem ser confundidos com a autoridade, sendo atos excepcionais usados normalmente quando a 
autoridade em si falhou. Ou seja, violência, coação ou ameaça, são distintos de autoridade. Quando as primeiras surgem numa relação, é justamente porque a autoridade perdeu sua legitimidade.

Pelo mesmo motivo, apesar de o nome autoridade remeter à palavra como autoritário ou autoritarismo, a confusão que possa surgir com essas palavras, não significa, em si, autoridade. O simples fato de que essas ações cumprem a função da autoridade, isto é, fazem as pessoas obedecerem, não significa que o sejam:

É como se eu tivesse o direito de chamar o salto de meu sapato de martelo porque, como a maioria das mulheres, o utilizo para enfiar pregos na parede (ARENDT, 2013, p. 124)

Para Weber (2004) o poder da autoridade é apenas o poder que detém legitimidade, seja por tradição, pelo carisma ou pela lei. Dessa forma, a autoridade não é apenas o poder de mando, o domínio puro e simples, ou a capacidade de se fazer obedecer, ao que se pode chamar arbitrariedade ou tirania. A autoridade possui pressupostos só compreendidos por uma análise histórica de sua vivência.

Peters (1973) considera que, tradicionalmente, a autoridade sempre existiu nas sociedades humanas, em menor ou maior grau, mesmo em sociedades igualitárias. Apesar de não se poder generalizar tais considerações, pode-se considerar que, pelo mesmo desde a fundação da sociedade patriarcal ocidental, há relações de autoridade (MOSÉ, 2013).

Em Platão (1999) e Aristóteles (1999) encontram-se a autoridade entre os jovens e os velhos, entre o médico e paciente, entre o comandante e seu exército. Neles, a autoridade é uma relação privada, de superioridade e de submissão, seja pela experiência, seja pelo conhecimento. Em qualquer dos casos, pelas circunstâncias, é uma relação que prescreve uma submissão, se não espontânea, ao menos voluntária e sem contestação.

Coulanges (2006), ao tratar da autoridade na república romana, relaciona-a ao poder do pai, do pater famílias, por ser o pai o sumo sacerdote do lar, único representante na terra dos deuses domésticos, origem de sua autoridade. Assim, ao morrer, o próprio pater se transformará num "ser divino, que os descendentes invocarão" (COULANGES, 2006, p. 74). Relacionada à divindade, a autoridade, não admite contestação e a submissão advém da compreensão de se estar diante de algo muito maior, que é a própria fundação da cidade, da família, da religião, enfim, da tradição.

A legitimidade dessas formas de autoridade se assentam em dois modelos. $\mathrm{O}$ primeiro, que ocorre na relação com o pater ou entre os velhos e os jovens, refere-se, conforme Weber (2004, p. 234) à: 
[...] a submissão pessoal ao senhor que garante a legitimidade das regras por este instituídas e somente o fato e os limites de seu poder de mando têm, por sua vez, sua origem em "normas", mas em normas não-estatuídas, sagradas pela tradição. Mas sempre prevalece na consciência dos submetidos, sobre todas as demais ideias, o fato de que este potentado concreto é o 'senhor'; na medida em que seu poder não está limitado pela tradição ou por poderes concorrentes, ele o exerce de forma ilimitada e arbitrária e, sobretudo, sem compromisso com regras.

O segundo modelo de autoridade, a carismática, é baseada no senso de liderança e carisma do líder, existente entre os generais e seus soldados ou entre médico e paciente. Sua legitimidade vem do reconhecimento do grupo quanto a suas qualidades, a partir de traços pessoais. Em qualquer um dos casos, isto é, tanto nessa forma, quanto na anterior, o poder é ilimitado e arbitrário, sendo norma apenas o que a autoridade diz que é.

A diferença entre esses modelos, no entanto, repousa na estabilidade. Ao ser baseada na tradição, a autoridade do primeiro tipo só é rompida por uma mudança nas bases da sociedade, ao passo que a segunda baseia-se no reconhecimento dado pelo grupo, de forma que se esse cessa, a autoridade não existe mais. Em qualquer um dos casos, porém, Weber (2004) considera que esses modelos não podem subsistir como centrais numa democracia, na vida em pluralidade, na diversidade. Para o autor, a racionalidade impede uma obediência sem contestação, ilimitada ou arbitrária. Por outro lado, tal como defende Aristóteles (1999), na democracia, todos seriam iguais, não havendo submissão nem poder ilimitado ou arbitrário.

Arendt (2013) considera que o modelo de autoridade adotado nas sociedades e instituições ocidentais estaria mais próximo do modelo romano, no qual a vida política é também baseada na tradição, na religião e na autoridade, ou seja, no pater famílias de Coulanges (2006). A autoridade que teria fundado a própria vida ocidental e que, portanto, também estaria presente na escola, de origem tradicional, baseada na tradição e na religião, mesmo quando tornada laica, que não admite contestação.

O problema dessa fundação é que a modernidade produziu questionamentos a tudo que se relacionasse à sociedade patriarcal, à autoridade tradicional, a qualquer coisa que não fosse baseada no racionalismo (ARENDT, 201. PETERS, 1972).

É nesse sentido que tanto Arendt (2013) quanto Peters (1973) vão apresentar o crescente questionamento à escola, à autoridade do professor e ao currículo colocado. Para Peters (1973) parece que se torna insuportável aceitar uma autoridade sem fundo racional, um motivo, uma razão de ser, daí Weber (2004) trazer a ideia de uma autoridade cuja legitimidade é a racionalidade, é a lei, a norma, o estado de direito.

Nesse sentido, o estado de direito é aquele no qual a legitimidade da autoridade advém de normas preexistentes aceitas por aqueles que a elas são subordinados. Em oposição, 
a autoridade deixa de ser tradicional ou carismática, ou seja, aquela que define as normas, e que, por isso mesmo, está acima delas. A autoridade racional, por seu turno, é aquela que detém, principalmente, obrigações. Daí a sua legitimidade em influenciar o comportamento de seus subordinados.

Essa autoridade nasce da norma que é criada em conjunto por aqueles que devem ser a ela submetidos. Sua legitimidade advém justamente do processo político de construção das normas e do fato de que a própria autoridade é a elas submetida. Com isso, a autoridade passa a se relacionar mais com uma ideia de respeito, conforme conceituada por Arendt (2013), do que com submissão. Ela se relaciona a uma forma de resolução de conflitos diante da impossibilidade de se ter de lidar, sozinho ou sozinha, a todo o momento, com o os conflitos da convivência humana. Nesse sentido, a autoridade surge como referência para a resolução de conflitos pela regulação e normatização.

Freire (1967, 1987 e 1996), no campo pedagógico, também vai considerar a autoridade como respeito, ao que ele chama de "autoridade democrática", relacionada primeiramente à competência funcional do professor. No entanto, tal competência é necessária apenas porque a incompetência desqualifica a autoridade. $\mathrm{O}$ cerne da autoridade, assim, é o respeito existente na relação entre a técnica do educador e a liberdade do educando:

\footnotetext{
Creio que uma das qualidades essenciais que a autoridade docente democrática deve revelar em suas relações com as liberdades dos alunos é a segurança em si mesma. É a segurança que se expressa na firmeza com que atua, com que decide, com que respeita as liberdades, com que discute suas próprias posições, com que aceita reverse. Segura de si, a autoridade não necessita de, a cada instante, fazer o discurso sobre sua existência, sobre si mesma. Não precisa perguntar a ninguém, certa de sua legitimidade, se "sabe com quem está falando?" Segura de si, ela é porque tem autoridade, porque a exerce com indiscutível sabedoria. (FREIRE, 1996, p. 37).
}

Assim, há uma relação entre a autoridade e a liberdade quando um clima de respeito se instala diante pela existência de relações justas, não havendo autoridade (ou ao menos não a "autoridade democrática") quando há uma postura de autoritarismo, rígida, que não aceita a criatividade do educando.

O papel da autoridade democrática não é, transformando a existência humana num "calendário" escolar "tradicional", marcar as lições de vida para as liberdades mas, mesmo quando tem um conteúdo programático a propor, deixar claro, com seu testemunho, que o fundamental no aprendizado do conteúdo é a construção da responsabilidade da liberdade que se assume. No fundo, o essencial nas relações entre educador e educando, entre autoridade e liberdades, entre pais, mães, filhos e filhas é a reinvenção do ser humano no aprendizado de sua autonomia (FREIRE, 1996, p. 37).

Apesar dessa relação entre autoridade e respeito e do momento de questionamento das instituições da modernidade, nas quais a escola se insere, todos os modelos de autoridade coexistem, muitas vezes numa mesma instituição, numa mesma 
pessoa. A autoridade, ao ser classificada como tradicional, carismática, quanto racional, não apresenta um processo linear, mas parâmetros para sua discussão (SHIPMAN, 1975).

Diante disso, a escola da atualidade tem entre seus fundamentos uma autoridade tradicional, o que explica algumas das críticas que vem recebendo dentro do questionamento geral da modernidade. Os processos da modernidade, contudo, criaram e desenvolveram um senso de autoridade diferente desses fundamentos, a chamada "autoridade democrática". No entanto, risco há de que, ao invés de uma transmudação de uma autoridade tradicional para uma "autoridade democrática", na escola, haja a instituição da violência ou da coação, sob o argumento de que cumprem a função de fazer obedecer.

\subsubsection{Disciplina}

A palavra disciplina está relacionada ao processo de controle, de ordem e de fragmentação do ensino. Teixeira (1956) vai relacioná-la também à punição, enquanto Focault (1999) vai relacioná-la ao poder disciplinar.

Sua etimologia, do latim disciplina, refere-se à relação entre mestre e discípulo, envolvendo, assim, um aspecto da autoridade, de submissão. Por outro lado, há também sua relação com a ordem, a organização, a possibilidade de controle dos próprios instintos, bem como também a fragmentação das ciências ou técnicas, de forma que se relaciona com a própria fragmentação do conhecimento humano (HOUAISS, 2001).

Assim, em cerca medida, a palavra disciplina possui relação com autoridade. Contudo, não será essa a concepção aqui considerada, e sim quanto aos últimos aspectos mencionados, isto é, ao controle e à fragmentação do ensino e da vida cotidiana.

A relação entre disciplina e estudos não é nova. Platão (1999) já relatara a importância da disciplina nos estudos para os jovens, relacionada ao controle dos sentidos, ao poder de concentração e à rotina.

Todavia, é com o já mencionado método Lancaster que o poder disciplinar se institucionaliza como fundamento da escola. Por tal método, tudo é organizado para que o indivíduo tenha sempre a sensação de estar sendo vigiado e, caso falhe, possa ser punido como exemplo aos demais (RIBEIRO, 1977. BASTOS, 1997. FOCAULT, 1999).

A partir de então cada classe passou a ter um programa específico, elaborado conforme seu nível de conhecimento e dirigido por monitores ou instrutores, alunos que se distinguiam por seus bons resultados. Eram eles os responsáveis por transmitir o conhecimento dado pelo professor, por controlar de fato a classe, bem como repreender e punir os demais alunos, podendo ser promovidos ou rebaixados ao longo do ano. Os melhores 
poderiam receber indicações para alcançar boas posições de trabalho (BASTOS, 1997). Assim, um dos motivos do sucesso do método é justamente a cooptação de um grupo dentro do próprio grupo subordinado, que perpetua a situação de desigualdade (FOCAULT, 1999).

Por meio desse método, havia então grande facilidade na manutenção da disciplina, pois o aluno, agindo somente mediante uma ordem e desejoso de ascender, submetia-se a um condicionamento destinado a torná-lo dócil e obediente. Com isso, era fácil, posteriormente, submeter o adulto às ordens e comandos da fábrica (FOCAULT, 1984) ou do estado e da sociedade como um todo (RUSSEL, 1956).

Há, assim, o que Cândido (1977, p. 111) trata como "superordenação racional”, deliberada pelo Poder Público. Ou seja, há uma preocupação com o espaço (o local, a organização, a disposição das coisas) e com o tempo (aulas de duração certa, para cada assunto ou ciência, bem como hora para cada coisa) como objetivo de maior produtividade, de maior controle, a fim de que se anule tudo que possa perturbar e distrair (FOCAULT, 1987).

Com isso, não sobra espaço para nada mais além do que o estabelecido no currículo oficial, que deve ser repassado dentro de uma perspectiva de produtividade certa. Não há pluralidade, não há convivência. Todos estão juntos num mesmo espaço, mas impossibilitados de conviver com a diferença. Assim, a disciplina implica uma separação, uma segregação. Os alunos são então separados por conhecimento e se estabelece um sistema seriado em que o primeiro ano é o pré-requisito do próximo, numa sucessão até os bancos da universidade. O resultado é a confusão mencionada por Illich $(1985,16)$ entre processo e substância:

[...] quanto mais longa a escolaridade, melhores os resultados; ou, então, a graduação leva ao sucesso. O aluno é, desse modo, «escolarizado» a confundir ensino com aprendizagem, obtenção de graus com educação, diploma com competência, fluência no falar com capacidade de dizer algo novo.

Tal processo é uma das formas mais eficientes de controle e submissão, pois:

Sem a capacidade de relacionar a experiência particular com o todo da vida, sem a capacidade de articular o todo da vida com um projeto social mais amplo, sem a capacidade de relacionar esse projeto social com o planeta e a vida, jovens e crianças terminam submetidos a processos e engrenagens que os tornam tão pequenos e insignificantes que não se sentem potentes para transformar aquilo que os oprime (MOSÉ, 2013, p. 52).

Dessa forma, como a apreensão do conhecimento não se dá de maneira relacional, cada conteúdo é dissociado do outro e a instituição educacional deixa de corresponder ao seu propósito de educar. Em outras palavras, a escola destoa como local direcionado à educação.

Para Teixeira (1956) ela se direciona a inculcar artes e conhecimentos 
desligados e abstraídos de suas funções reais na vida e, como tais, sem sentido. Por serem dessa forma, são difíceis de serem apreendidos, não despertando atenção dos estudantes. Há então, a instituição das resistências: a distração, a desordem, o absenteísmo e, em consequência, a aplicação do poder disciplinar, da punição e da exclusão (FOCAULT, 1999).

Por outro lado, só o fato de se estar na escola já envolve um tipo de exclusão da vida social. Estar na escola é estar fora do mundo. A parti de Focault (1999) é possível perceber que a nossa sociedade se relaciona com o que não aceita, não compreende ou não concorda excluindo ou isolando. Mas é também essa uma forma de a instituição exercer maior controle sobre os corpos a ela submetidos.

Nesse sentido, tanto o exame quanto a prova são colocados como pontos centrais desse poder por desenvolverem dois processos em um: a vigilância e a normalização, que classificam, objetificam e constroem identidades pautadas nessa classificação:

É por isso que, em todos os dispositivos de disciplina, o exame é altamente ritualizado. Nele vêm-se reunir a cerimônia do poder e a forma da experiência, a demonstração da força e o estabelecimento da verdade. No coração dos processos de disciplina, ele manifesta a sujeição dos que são percebidos como objetos e a objetivação dos que se sujeitam. A superposição das relações de poder e das de saber assume no exame todo o seu brilho visível (FOCAULT, 1984, p. 209).

Sobre esse assunto, pode-se citar também Mosé, quando diz:

A escola foi e ainda é, em nossas vidas, um dos primeiros momentos em que esse mecanismo de exclusão é aplicado. Primeiro porque a escola é uma instituição isolada da cidade, da comunidade. Segundo porque o sistema de reprovação é um dos primeiros processos de exclusão que atinge as crianças, com enorme prejuízo para seu desenvolvimento: a escola não se responsabiliza pelo desempenho insuficiente do aluno; ao contrário, quando reprova transfere para o aluno todo o fracasso (2013, p. 44).

O poder disciplinar, assim, não é apenas o aspecto punitivo do sistema educacional. Ele é uma ordenação, do espaço, do tempo, dos conteúdos ministrados, pensada e estruturada de forma a tornar desnecessário o aspecto punitivo ao permitir o maior controle das ações e dos pensamentos daqueles a ele submetido.

Dentro desse contexto, fundado sob os signos da autoridade tradicional e do poder disciplinar, a escola transmuda-se em instituição que não permite o questionamento ou a contestação. É, assim, o que Shipman (1975) e Castoriadis (1982) chamam de "instituição total": desejosa de controlar e condicionar o comportamento humano abafa e escamoteia qualquer conflito por compreendê-lo como rompimento à ordem estabelecida. É esse o currículo real escolar, inserto em cada um dos conteúdos apresentados.

Tudo isso, no entanto, numa sociedade que rompeu com a autoridade e que perpetua ações de resistência ao poder disciplinar ao mesmo tempo em que legitima o conflito 
pelo sistema democrático. Como resultado, há a deslegitimação da escola ao mesmo tempo em que ela é colocada como instituição promotora de transformação social. É o que Gentili (2009) e Pain (2010) chamam de escola dos paradoxos.

\subsubsection{A escola dos paradoxos}

Fundada sobre si mesma, auto-reprodutora, conservadora, mas que permite a contradição, a sociedade do século XIX gera a sua própria antítese. Isso significa que, ao mesmo tempo em que institucionaliza a escola total, permite o surgimento das pedagogias de emancipação (PAIN, 2010), como as escolas de resistência de Singer (2010) ou ainda, no Brasil, as pedagogias dos "escolanovistas", de Azevedo (1977) e Teixeira (1956).

Com isso, a escola se transforma na escola das promessas: uma escola pública, de qualidade, para todos, vista como promessa de sucesso profissional e na vida e também uma instituição de transformação da sociedade, enfim, o melhor lugar para as crianças e os adolescentes ficarem (MOSÉ, 2013. PAIN, 2010. TEIXEIRA, 1956. ILLICH, 1985).

Com o pós-guerra, no entanto, surge uma sociedade, que Pain (2010) vai chamar de complementar, em que a vida cotidiana é fragmentada e os conflitos são regulados pela disseminação do controle. Ocorre, então, a massificação escolar: a escolarização obrigatória para os anos secundários que, nos Estados Unidos, deu-se a partir da década de 1950 e, na Inglaterra, na década seguinte (OTTAWAY, 1962. CHIPMAN, 1975).

No Brasil, esse processo ocorre com a Constituição de 1988, com a garantia da universalização do ensino médio gratuito e a instituição da educação básica até os 17 anos (BRASIL, 1988). Contudo, somente em 2009, 97,9\% das crianças de 7 a 14 anos de idade passaram a frequentar o ensino fundamental, permanecendo ainda desafio em relação aos adolescentes de 15 a 17 anos, diante da evasão escolar (BRASIL, 2009 e 2011).

No entanto, na sociedade complementar há um engessamento do modelo escolar em um tipo autoritário e consensual, com função de reorganização do pensamento e das pessoas, instituído na França de De Gaulle (PAIN, 2010) e também no Brasil, com o governo militar (MOSÉ, 2013). Tal escola continuará a ser desenvolvida no período de abertura democrática (PAIN, 2010. MOSÉ, 2013), quando a educação se instaura como direito social, mas a escola adota o modelo técnico, fragmentado. E nesse paradoxo:

[...] tudo se promete sem de fato se ter; de quebra, controla-se a execução do que foi imposto. Privilegiam-se certos comportamentos, declarados corretos, sem que sua prática ou a valorização social dela decorrente sejam ressaltadas. Ao contrário, sancionam-se as falhas ou a ausência de sucesso. O fracasso é um erro de seleção de pessoal (PAIN, 2010, p. 10). 
As condutas são então prescritas e toda a estrutura é organizada de forma excludente, surgindo comportamentos de proteção e isolamento. Com isso, as relações entre os participantes da escola, isto é, os adultos, as crianças, os adolescentes e o currículo tornamse cada vez mais conflituosas (PAIN, 2010. MOSÉ, 2013).

Ao mesmo tempo, vigoram as políticas públicas, em especial na América Latina, com ênfase na "política de expansão e aumento dos índices de matrícula e a política do aprimoramento da qualidade e da eficiência" (STEIN ett alli, 2006, p. 219). Situação que Gentili vai chamar de "dinâmica de exclusão includente" (itálico no original):

[...] um processo mediante o qual os mecanismos de exclusão educacional se recriam e assumem novas fisionomias, no contexto de dinâmicas de inclusão e inserção institucional que acabam sendo insuficientes ou, em alguns casos, inócuas para reverter os processos de isolamento, marginalização e negação de direitos que estão envolvidos em todo processo de segregação social, dentro e fora das instituições educacionais (GENTILI, 2009, p. 1061).

E assim, enquanto a sociedade luta por maior democratização, há a negação dessa mesma democratização às mais diversas instituições, entre elas a escola (GENTILI, 1998). O argumento central é a necessidade de se trabalhar a "qualidade" na educação em detrimento de outros aspectos, em busca de uma escola que permita a vida na "sociedade do conhecimento" (GENTILI, 2003, p. 257). Com isso, os fundamentos da escola permanecem:

[os adultos] exercem um conjunto de pressões que atendem mais aos interesses da organização social do que aos interesses destes [alunos], e estes regem a seu modo, procurando dar expressão a sua sociabilidade própria. Estabelece-se deste modo uma dupla corrente de sociabilidade: a que envolve o ajustamento do imaturo aos padrões do adulto, e a que exprime as necessidades e tendências. Na confluência de ambas situa-se a prática pedagógica, tanto mais satisfatória quanto melhor conseguir atenuar a tensão das duas correntes (CANDIDO, 1977, p. 110).

Para Karl Mannheim e William Stewart (1977), os alunos são submetidos ao professor a fim de receberem informações ("o que não significa que aprendam" MANNHEIM; STWART, 1977, p. 133) e serem vigiados e corrigidos, ao passo que o professor é um líder institucional, com conhecimento e com "a responsabilidade para planejar como comunicá-lo a um grupo de crianças que podem não desejar aprender o que ele apresenta” (MANNHEIM; STUART, 1977, p. 135). O resultado é uma escola direcionada apenas a sua preservação:

[...] as ações que se desenvolvem se restringirão meramente à preservação da escola enquanto organização, levando professores e direção a abdicar de tarefas próprias do educador, pensadas como alguém que se ocupa de fornecer, além do conhecimento técnico e científico, os valores universais do ser humano (SILVA, 2010, s.p).

Isso significa que os aspectos morais, relacionados à socialização, são restritos à disciplina e ao respeito ao regulamento e somente na medida em que sejam úteis à preservação do estabelecimento. Caso um comportamento ou ação não se enquadrem, eles 
não são pensados na escola. Daí, por exemplo, trabalhos sobre o bullying, conforme se verá adiante, enfocarem apenas o comportamento individual dos alunos, esquecendo-se a organização escolar e o imaginário por trás das ações cotidianas (SILVA, 2010).

Enquanto isso, Shipman (1975), Arendt (2013) e Freire (1996) lembram que a educação se tornou uma ação política, o que significa que qualquer mudança pretendida na sociedade passa a significar uma mudança pretendida na própria escola e em seu currículo, questão que se torna mais acirrada a partir das grandes guerras do século XX e da busca por bases para a solidariedade e a democracia (ARENDT, 1999).

É, então, que a educação para os direitos humanos surge na escola como uma forma de promover a dignidade humana, a igualdade de direitos, o reconhecimento e a valorização das diversidades e a democracia (BRASIL, 2007).

Assim, quanto mais a sociedade questiona a si mesma, mais a escola sofre mudanças curriculares, mais é questionada e mais se acirram as relações internas (SHIPMAM, 1975) criando espaço para mudanças no conteúdo do currículo. Contudo, ao se mudar o currículo oficial não se mudam os fundamentos da escola, as condições para o seu funcionamento adequado: a disciplina e a autoridade, seu currículo oculto como instituição direcionada à perpetuação da desigualdade e de adaptação ao sistema capitalista permanecem.

Como resultado, conflitos, dissensos e contestações, não resolvidos pela autoridade ou pelo poder disciplinar, mas pela coação, violência ou ameaça (ARENDT, 2004 e 2005) instalam um ciclo vicioso que gera uma explosão de conflituosidade. Essa, por sua vez, ao não ser enfrentada devidamente, dá origem às mais diversas violências. É nesse ponto, então, que trabalhar a relação entre conflito, violência e escola tornou-se uma questão central neste

trabalho. 


\section{VIOLÊECIA}

Quando falamos de violência, podemos falar do uso excessivo da força, da ação direcionada a destruir algo. Esse é o sentido etimológico do latim violentia, impetuosidade, violentus, o que age pela força e violare, tratar com brutalidade, desonrar, ultrajar, violar. Assim, a violência relaciona-se à destruição, a "uma ação que deteriora ou destrói aquilo a que se aplica" (BLACKBURN, 1997, p. 405).

Esse é o sentido dado por Stoppino (1995) ao considerá-la a intervenção física voluntária de um indivíduo ou grupo contra outro indivíduo ou grupo com o objetivo de destruir, ofender ou coagir. Nesse sentido, violência é exterior, brutal e fisicamente dolorosa.

Contudo, ao utilizar apenas esses sentidos podemos ser levados a relacionar a violência à criminalidade, estigmatizando certos grupos ou negligenciando certas ações violentas por não serem crimes. Há, é verdade, crimes cujo núcleo central é a violência, como o latrocínio. Contudo, há todo um conjunto de crimes que não faz uso dela (furto, estelionato, receptação, corrupção), outro no qual seu uso pode apenas acirrar as consequências aos agentes, fornecendo uma qualificação ao crime (dano), bem como ações violentas que não se constituem crimes no sentido estrito (atos infracionais, rituais de passagem).

Diante disso, Abramovay e Rua (2002) conceituam violência qualquer agressão, física, moral ou institucional, contra a integridade física ou psíquica de um indivíduo ou grupo. Há, então, uma ampliação do conceito que envolve também outras violências, como a psicológica.

Em Arendt (2004) encontra-se um conceito de violência relacionado a ações instrumentais direcionadas a perpetuar ou estabelecer relações de mando e obediência. Nesse sentido, a violência se consubstancia no aumento da força e do vigor humanos, existente justamente quando a autoridade deixou de existir.

A ideia de violência como ação instrumental também pode ser encontrada em Pasquino (1995) e Jarez (2007). Contudo, para tais autores, ela se desenvolve na negação de quaisquer regras ou mesmo do reconhecimento ao outro.

Galtung (2003, p. 93), ao trabalhar o conceito de não-violência, considera a violência "qualquer coisa que possa impedir a auto-realização individual, não apenas atrasando o progresso de uma pessoa, mas também o mantendo estagnado".

Com isso, é possível perceber que o conceito de violência pode ter tanto uma acepção ampla como uma acepção restrita, envolvendo apenas a ação física. 
Além disso, mesmo numa acepção mais restrita, o que é violência pode variar conforme o lugar ou a classe social. Nesse sentido, por exemplo, Debarbieux (2006) considera que, conforme o país envolvido, violência pode ser desde uma simples contestação até os atos mais criminosos. Por outro lado, o mesmo tipo de comportamento pode ser avaliado, conforme a classe social, como um crime ou ainda um simples ato de incivilidade, ou seja, uma simples "grosseria" (CHARLOT, 2002).

Debarbieux e Blaya (2002) bem como Charlot (2002) acrescentam ao foco a repercussão da violência sobre a vítima. Nesse sentido, ações que podem até ser consideradas banais, em especial dentro de conceitos mais estritos de violência, mas que têm o condão de causar tamanho sofrimento às vítimas, são também violência, pois lhes negar tal atributo significa um ataque à dignidade dessas pessoas, bem como a perpetuação das situações.

Assim, trabalhar uma conceituação de violência mostra-se complexa porque envolve muitas variáveis, além da consideração do período histórico e do seu locus de atuação, não havendo uma teoria única ou completa sobre o tema.

Aliás, Wieviorka (1997) já falou sobre isso quando disse que qualquer ação que signifique a tentativa de se estabelecer uma teoria total da violência só vai alcançar o fracasso. A violência só pode ser compreenda a partir do contexto em que se encontra. Diante disso é que o presente trabalho adota uma conceituação ampla, não a configurando apenas como ação direta, humana, direcionada a outrem, vinculada à criminalidade.

A violência compreendida aqui se relaciona a qualquer ação ou omissão direcionada a destruir ou deteriorar a pessoa, grupo ou objeto a que se destina. Contudo, considerando o tema do presente trabalho, a violência mencionada é a que ocorre no contexto escolar. No entanto, antes de se discutir tal violência é necessário explicitar algumas concepções e classificações mais gerais sobre o tema.

\subsection{Concepções acerca da violência}

A violência sempre fez parte da história humana. Muitos dos processos históricos pelos quais os seres humanos têm passado, suas lutas políticas e suas conquistas, deram-se por meio da violência, seja pelas revoluções, pelas guerras ou pelas conspirações. Parece até mesmo, conforme Wieviorka (1997), que a violência seria uma obrigação diante da tirania.

Tal situação parece levar a uma associação direta entre humanidade e violência a ponto de haver quem considere que o ser humano é, naturalmente, violento. A violência, assim, seria um derivado de nosso aspecto animal, algo instintivo (ARENDT, 2004. 
WIEVIORKA, 1997). Diante disso, nada mais natural do que situá-la nos jovens, considerados, então, impetuosos, cheios de vitalidade, ainda não submetidos totalmente ao controle social e mais próximos de nossa natureza animal (ARENDT, 2004). Eles então é que seriam mais violentos.

Contudo, o século XX viu o questionamento dessa concepção, em parte pela experiência das grandes guerras, em parte pela ascensão de ideologias contrárias à violência e defensoras dos direitos humanos como paradigma cultural, em parte pelo desenvolvimento das ciências sociais. A violência, então, tornou-se uma ação política (ARENDT, 2004).

Ação política, aqui, não se refere a uma ação contrária a um Estado ou governo, mas à vida oposta à natureza, aos instintos. Conforme Arendt (2004) a violência é uma ação política por estar relacionada à racionalidade e vinculada a uma finalidade e a um agir estratégico. Em outras palavras: agir de forma violenta é uma escolha.

Ser uma escolha significa que a violência é uma ação voluntária, pois a involuntariedade exclui a violência e constitui o acidente (STOPPINO, 1995). A voluntariedade, então, torna-a uma ação deliberada, racional e dissociada de uma natureza humana instintiva ou natural. Ser voluntária também significa que a violência não precisa ser espontânea. Ou seja, a decisão de agir de forma violenta pode vir de fatores externos, esses podendo até mesmo ser incontroláveis para os agentes.

Sendo assim, o instinto para a guerra, para a revolução ou para o assassínio não é inerente à natureza humana e essa é, inclusive, a concepção presente no Manifesto ou

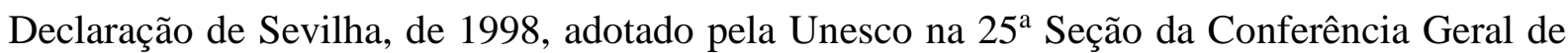
1989, que diz:

É CIENTIFICAMENTE INCORRETO dizer que herdamos uma tendência a fazer guerra de nossos ancestrais animais (...).

É CIENTIFICAMENTE INCORRETO dizer que a guerra, ou qualquer outro comportamento violento, é geneticamente programado na natureza humana (...).

É CIENTIFICAMENTE INCORRETO dizer que no curso da evolução humana houve uma seleção de comportamentos agressivos mais do que de outros tipos de comportamento (...).

É CIENTIFICAMENTE INCORRETO dizer que os humanos têm (sic) um "cérebro violento" (...). A forma como agimos é determinada pelo modo como fomos condicionados e socializados. Não há nada em nossa neurofisiologia que nos obriga a reagir violentamente.

É CIENTIFICAMENTE INCORRETO dizer que a guerra é causada por "instintos" ou por qualquer motivação isolada (...).

Por ser ação política, ainda que não integre o instinto ou a natureza humana, a violência integra a condição humana (ARENDT, 2004), a essência que nos distingue dos animais. É nesse sentido que Drawin (2011) vai negar a ação violenta como não natural ao ser humano e vai localizá-la na cultura. 
Cultura é, para Drawin (2011), dentro de uma perspectiva antropológica, o processo que diferencia o ser humano do mundo da natureza, construído ao longo de um processo histórico, mesma concepção vista em Freire (1996) e Teixeira (1956) no capítulo 1.

Diante disso, a violência, ainda que não seja algo natural ao ser humano, também não pode ser eliminada, pois a própria cultura não o poder ser. Nas palavras do autor:

[...] se a violência é um elemento constitutivo dessa dialética interna da cultura, então o desenvolvimento histórico da cultura, que aqui podemos designar por comodidade como processo civilizatório, não pode ser interpretado como um progresso linear que deixa a violência para trás, como um estágio primitivo ou um resíduo da animalidade do homem.

Fica, assim, delineado um paradoxo: a violência não só não pode ser radicalmente eliminada da cultura, mas o processo de complexificação da cultura que chamamos de civilização engendra novas figuras da violência que podem ser ainda mais destrutivas. Violência e civilização não são excludentes, mas se relacionam intimamente. Assim, o crescimento econômico, o desenvolvimento técnico, as conquistas políticas e jurídicas, a dominação da natureza, a racionalização do mundo, enfim, tudo aquilo que caracterizamos como o progresso moderno não elimina por si mesmo a violência, uma vez que esta não é um resíduo nem da agressividade animal e nem da suposta vida primitiva, mas parece ser antes uma condição antropológica e uma possibilidade inerente da civilização (DRAWIN, 2001, p. 17-18).

Apesar desse posicionamento, Drawin (2001, p. 20) recusa uma visão de naturalização da violência que pode nos levar a considerar que "as coisas são assim". Isso porque, para o autor “"as coisas' é apenas uma forma de nomear a atual ordenação sistêmica e hegemônica do mundo". Ao contrário:

[...] o paradoxo antropológico que procurei esboçar não é de modo algum uma posição niilista, mas argumenta contra a ingenuidade da posição iluminista, que não consegue explicar a violência que eclode no coração do mundo civilizado. A tese do paradoxo antropológico não se confunde com o abandono da esperança histórica e do compromisso político, mas exige a radicalização do pensamento, um aprofundamento da compreensão crítica da violência e uma atitude prudencial acerca do otimismo ilustrado (DRAWIN, 2001, p. 20).

É justamente dentro dessa visão que Wieviorka (1997) traz a concepção de que a violência vivida na atualidade tem suas causas nas contradições inerentes à própria modernidade. Em outras palavras, a violência se deve aos aspectos do que é contemporâneo, do que espelha a modernidade, ou mesmo sua crise.

Ao se trabalhar a modernidade e a violência, em Drawin (2001, p. 24) encontra-se uma dialética formada, principalmente, por dois movimentos: uma modernização social que exclui "toda referência a uma instância transcendental ou a um lugar terceiro que possa servir de mediador de conflitos" e uma modernização cultural que fragmenta todas as esferas de valor ao mesmo tempo em que cria uma hermenêutica crítica dessa mesma cultura.

Nesse aspecto, em especial a partir do século XX, a violência, principalmente a considerada direta, física ou subjetiva, perde qualquer conotação positiva que pudesse ter e 
passa a ser "a marca do que é preciso recusar" de forma que, dentro da modernização e das democracias, parece não haver espaço para ela. Mas, ao mesmo tempo, ela se torna uma categoria mais geral, que passa a explicar tanto as relações internacionais, a sociedade, interna ou externa, quanto a comunidade circundante (WIEVIORKA, 1997, p. 08). Isso significa que há uma expansão do termo e a violência passa a ser compreendida como os próprios aspectos sociais e culturais da sociedade, um prolongamento dos problemas sociais. Ela explica a sociedade, mas sempre como algo que não deveria estar lá. Diante dessa nova realidade ou novo paradigma, para Wieviorka (1997), são diversas as violências que surgem.

\subsubsection{Violência subjetiva}

A violência subjetiva é a mais facilmente identificável e muitas vezes considerada a forma real de violência (STOPPINO, 1995). Ela é o ato direto realizado pelo ser humano, direcionado à destruição de algo por meio do excesso da força ao que se direciona.

Tal violência é vista e compreendida como necessária diante de uma agressão. Ela se reveste no direito de resistência ou de levante diante da necessidade de luta pela liberdade. No entanto, em vários aspectos, tal violência pode carecer de um senso de sentido.

É aí que ela se torna o absurdo expresso na ideia da "gratuidade da violência" (DRAWIN, 2001, p. 26). Wieviorka (1997) vai identificá-la na "paixão pelo risco", na ausência de introjeção de normas sociais ou ainda na pura e simples negação da alteridade, na desumanização e destruição do outro, enquanto expressa a supremacia da subjetividade de quem a exerce. Essa última acepção é encontrada também em Jares (2002 e 2007) e Pasquino (1995), ao identificarem-na na negação das regras ou de qualquer normatividade presente. É a própria situação de anomia que a educação tenta evitar (DURKHEIM, 1977).

Todavia aquele que, pela violência, desumaniza o outro e eleva sua subjetividade (colocando-se como superior frente a esse outro), conforme Wieviorka (1997), também se desumaniza ao se impedir a perplexidade diante de seus próprios atos. Assim, a violência passa a ser algo apenas banal.

Apesar disso, apenas desumanização não traz violência. É nesse sentido que Arendt (1999) lembrar que a desumanização gera mais facilmente a burocratização da vida e da morte, aceita por todos como "o que é", ou seja, cria-se uma sensação de que as coisas são assim, o que gera o vazio, expresso, por exemplo, nas experiências históricas nas quais os indivíduos tornaram-se apenas uma engrenagem que não questiona, mas apenas busca como se tornar mais eficiente, ainda que seja na completa destruição do outro. 
Dizer isso não significa considerar que as ações presentes no holocausto não tenham sido violentas. Apenas que o processo de desumanização baseia-se mais num anestesiamento quanto ao outro do que no acirramento da violência. Tal processo traz o horror, o mal, algo inexplicável (ARENDT, 1999) mas que não necessariamente gera a violência no sentido aqui exposto. Assim, a violência tem uma relação mais próxima com o ódio, embora se deva considerar que:

O ódio não é de forma alguma uma reação automática à miséria e ao sofrimento; ninguém reage com o sentimento de ódio a uma doença incurável ou a um terremoto ou a condições sociais que parecem imutáveis (ARENDT, 1999, p. 39).

A violência, principalmente a que parece gratuita, não vem da desumanização, mas do ódio, que nasce da sensação de impotência, de perda do poder e da suspeita ou certeza de que as condições poderiam ser outras. Ela torna-se, então, um recurso tentador em condições ultrajantes, mas mutáveis, quase numa tentativa de se equilibrar a balança (ARENDT, 2004).

Tal condição ultrajante não se refere apenas aos aspectos econômicos ou sociais, ou se estaria a legitimar o argumento de que violência existiria apenas entre os pobres. A violência vem da perda do medo da punição (pois a punição só faz sentido quando há receio dela, quando há o medo) e da sensação de que nada há a se perder, tal é a situação de ultraje. Assim, quando nada mais resta, as opções são entre a violência e (ou) a acomodação e, nessas opções, diante do ódio, a violência parece a opção mais fácil (ARENDT, 2004).

Por outro lado, ela também pode surgir pela necessidade de reconhecimento e ingresso na sociedade. $\mathrm{O}$ indivíduo, na atualidade, tem sua identidade formada a partir do que pode consumir. Tal consumo, no entanto, deve permitir seu reconhecimento como sujeito único, que não está preso aos papéis e a normas tradicionais, de forma que a violência, de forma instrumental, surge para se alcançar tal objetivo:

O ator de muitas violências instrumentais, por exemplo, engaja-se com finalidades
econômicas, ele quer o dinheiro para consumir, comprar, pra si mesmo e
eventualmente para os seus. De modo bem distinto a violência pode assumir uma
feição extrema, ilimitada, relacionada com um desejo, frustrado, de acender aos
frutos da modernidade e sem que se trate de utilizá-lo como recurso para alcançar
determinados fins (WIEVIORKA, 1997, p. 23).

Diante disso, a violência gratuita não parece tão gratuita assim. Ela surge como paga de uma situação permanente de ultraje aliado ao ódio pela ausência de poder de mudança, tudo isso dentro de um sistema que incentiva também o consumo e a necessidade da expressão de uma vida única, especial, fora dos papéis tradicionais. Ao se relacionar a um sistema, percebe-se então que há outra face da violência: a chamada violência objetiva, que 
abarca tanto o que Drawin (2001) vai chamar de sistêmica, o que Galtung (1969) vai considerar estrutural e Bourdieu (1989) vai chamar de simbólica.

\subsubsection{Violência objetiva}

A violência objetiva relaciona-se aos sistemas de relações de toda uma sociedade, "cuja falta ou enfraquecimento criam o espaço da violência" (WIEVIORKA, 19997, p. 27). É uma violência sóciossimbólica, moral, que permaneceria mesmo se as violências subjetivas findassem, por se constituir na autorreprodução dos sistemas econômicos e sociais (WIEVIORKA, 1997. DRAWIN, 2001. GALTUNG, 1969 e 1990).

Para Weber (2004) o Estado é uma associação de dominação, única legitimada a exercer a violência no caso do desrespeito a suas normas. Contudo, o declínio da noção do Estado-nação, ocasionado seja pelas lutas de direitos humanos, que interpelam em busca de um Estado multicultural, seja pelo processo de globalização, que ocasiona o crescimento das atividades informais, o fortalecimento do mercado e do trabalho clandestino, faz com que haja o que Wieviorka (1997) chama de "privatização da violência".

Nesse modelo, a violência é realizada por grupos privados que desenvolvem uma economia própria, ilegal, cujo interesse é justamente manter o Estado afastado, a fim de permitir maior dominação e controle territorial. A violência instrumental, então, surge nesse vazio estatal, constituindo-se em processos difusos que, para Wieviorka (1997), atraem pouca atenção da mídia ou mesmo do Estado, só percebida nas estatísticas.

No Brasil, é possível encontrar esse tipo de violência, tanto na área urbana quanto rural, por meio dos índices de mortes violentas por armas de fogo, por exemplo, tais como indicam Waiselfisz (2014) e seus mapas da violência. Os dados revelam índices tão altos que são comparáveis apenas aos de países em conflitos armados ou em guerras.

Nesse sentido, a violência advém tanto da ausência de segurança pública quanto do acesso escasso a serviços básicos, o que é compartilhado por Sposito (2001), Njaine e Minayo (2003) e Abramovay et al. (2002). Assim, o Estado se afasta (ou sequer se aproxima) e grupos particulares ocupam o que seria monopólio estatal: o espaço do direito à violência diante da confrontação a suas normas.

A ideia de uma privatização da violência não exclui a violência estatal em si ou dentro dos Estados-nações. Os atuais conflitos armados são apenas alguns dos exemplos. Contudo, o Estado também tem sido um dos principais responsáveis pela violência por meio da atuação de seus próprios agentes. Quanto a isso, basta mencionar os casos de tortura 
policial ou índices de letalidade e demais violações de direitos das forças policiais internas no Brasil, expressos por Bueno e Lima (2012) e Loche (2010).

O resultado dessa situação é justamente a perpetuação desse sistema em outras esferas, por meio do acirramento do ódio, da perda do medo e da reprodução do modelo. É por isso, que Wieviorka (1997, p. 10) considera o Brasil um país que tolera ou suporta a violência, percebendo-a "quase como inscrita no funcionamento normal da sociedade".

Mas essa violência também se encontra na própria conjuntura econômicosocial baseada na concepção de uma sociedade capitalista. É nesse sentido que Wieviorka (1997) lembra os anos 1950 e 1960, quando vigorava a ideia de democratização e industrialização em direção a um progresso permanente, que permitisse o acesso a bens de consumo a todos. A ideia passada é que esse sistema se traduziria em regressão da violência.

É o american way of life que não se reproduz, na verdade, para todos, mas só existe a partir da opressão de muitos, submetidos, esse sim, à precarização do trabalho e ao esgarçamento das relações sociais. Como resultado:

[...] a raiva e o ódio dos jovens exprimem-se certamente tendo por trás um cenário marcado por dificuldades sociais, mas correspondem acima de tudo a sentimentos fortes de injustiça e de não reconhecimento, de discriminação cultural e racial (WIEVIORKA, 1997, p. 22).

Mais uma vez, isso não significa que haja uma relação direta entre aspectos econômico-sociais e violência. Apenas que, se de um lado elas podem criar frustrações que alimentam violências diversas, entre elas as coletivas ou racistas (WIEVIORKA, 1997), podem também naturalizar as desigualdades sociais, estabelecendo, mais uma vez, cidadãos de segunda categoria (GALTUNG, 1990) que, frente a uma realidade de necessidade consumista, passam a estar dispostos a alcançar seus objetivos por quaisquer meios.

Diante de tais colocações questiona-se se a ausência do Estado não seria ela própria violência (e não apenas sua causadora). Esse é um questionamento feito por Freire (1987; 2001) para quem a violência real é justamente a que estabelece situações de miséria e opressão. E é diante desse questionamento que surge a constituição da violência estrutural.

A partir de Weber (2004) encontra-se um delineamento da violência estrutural, sendo a que nasce diante da perda da legitimidade do Estado. É a ausência da autoridade, legal ou racional, o que se consubstancia nos abusos do poder. Não se relaciona ao monopólio legítimo da força porque, nesse caso, a legitimidade se assenta na constituição de um Estado de Direito, ou seja, baseado em leis criadas dentro de um processo democrática e a que o próprio Estado deve obediência. É, ao contrário, a perda da legitimidade dessa força que leva à instituição da violência. 
Esse tipo de violência é relacionado também às estruturas organizadas e institucionalizadas da sociedade, conforme Minayo (1994, p. 08):

Aquela que oferece um marco à violência do comportamento e se aplica tanto às
estruturas organizadas e institucionalizadas da família como aos sistemas
econômicos, culturais e políticos que conduzem à opressão de grupos, classes,
nações e indivíduos, aos quais são negadas conquistas da sociedade, tornando-os
mais vulneráveis que outros ao sofrimento e à morte.

Já Galtung (1969 e 1990) trabalha um conceito de violência estrutural não apenas como um marco à violência subjetiva, mas um processo de construção da realidade. Para ele é a violência estrutural que fornece os argumentos que justificam o status quo.

Enquanto a violência subjetiva, que Galtung (1969 e 1990) vai chamar de direta, relaciona-se a eventos específicos, a uma ruptura ou choque, a violência estrutural passa a sensação de normalidade, de estabilidade, na qual as mudanças parecem ocorrer de forma lenta, dentro de um processo histórico.

Isso porque a violência estrutural, tanto na esfera estatal quanto social ou individual, é a situação naturalizada pela sociedade, relacionada à exploração da violência direta. Os problemas sociais da cidade e casos de desnutrição são alguns dos exemplos de violências estruturais que acabam estabelecendo cidadãos de segunda categoria, grupos específicos e estratificados e relações desiguais de poder e autoridade (GALTUNG, 1990).

Há então uma relação de continuidade entre a violência objetiva e a subjetiva de forma que uma espelha a outra, tanto no campo individual quanto social, estatal ou supranacional, de forma que considerar apenas uma delas é ignorar suas causas.

Mas se a violência é algo cultural, construído historicamente e os mecanismos de sua criação surgem da cultura humana ou de seus aspectos simbólicos, está-se diante da violência simbólica (BOURDIEU, 1989. BOURDIEU; PASSERON, 1975).

Violência simbólica é o poder utilizado de forma a assegurar a dominação do grupo dominante sobre um grupo dominado. Ela é simbólica porque é constituída das artes, da religião e da própria linguagem, ou seja, os aspectos simbólicos da existência humana, que formam e constroem a própria realidade em que vivemos. É o que se refere à "história oficial", ao padrão, ao senso comum, ao que é considerado belo e bom pela sociedade. Constitui-se violência porque tais padrões definidos são arbitrários e a imposição é dada sem motivo, apenas pelo fato de que se transmuta na cultura do dominante (BOURDIEU, 1989. BOURDIEU; PASSERON, 1975). Ela é permanente porque se dá na interiorização dos valores culturais e encontra entre os dominados os seus sustentáculos. 
Há uma relação entre as violências direta (subjetiva), cultural e estrutural (objetiva). De acordo com Pureza (2011, p. 14) a primeira aparece como um fato ao passo que a estrutural é um processo e a cultural é uma imanência, "uma invariância, uma permanência". Galtung (1990) considera que a violência cultural atua no sentido de promover a violência direta bem como justificar violência estrutural.

No contexto escolar, todas essas violências se encontram, havendo a necessidade de sua configuração nesse locus de atuação.

\subsection{A Violência no contexto escolar}

No contexto escolar, a violência tem sido um tema recorrente para os mais diversos autores. Mas assim como a violência lato senso, aqui também ela possui diversas conotações, conforme a época, o lugar e o meio social em que se encontra.

Até o século XX a violência era vista de uma forma determinista, individual e psicológica, o que também se espelha no âmbito escolar (LISBOA, 2008). Nesse momento, no entanto, não se está num modelo de escolarização de massa e a maioria das crianças e adolescentes, principalmente as mais pobres, estão fora da instituição.

No início do século XX, a violência no contexto escolar passa a ser vista na relação entre delinquência e criminalidade dos jovens, tal como prevê a Escola de Chicago. Contudo, ela é relacionada apenas ao seu aspecto social, à problemática da emigração e à ausência de adaptabilidade de imigrantes (ABRAMOVAY et al., 2009. ZALUAR, 2004. BECKER, 1996). A ideia então presente é que o crime é um produto exclusivamente do meio, que limita o poder de escolha do indivíduo.

Nesse sentido, a delinquência juvenil seria determinada pela situação econômica e pelo local em que viviam (desorganizado socialmente, sem laços familiares ou sociais próximos), que representavam quebra nos "valores tradicionais". Tal violência era percebida como um fenômeno circunscrito a um pequeno número de jovens, migrantes, não adaptados à sociedade e que encontravam nas gangues os laços sociais que de outra forma não possuiriam (ZALUAR, 2004. BECKER, 1996).

Diante dessa situação, a perspectiva era que a violência diminuiria por meio de ações preventivas, entre as quais a urbanização e a organização da cidade e, em relação aos jovens, a escolarização, como lembra Illich (1985).

Havia, assim, a crença de que a integração dos jovens se daria de forma natural por meio da educação e da inculcação dos valores dominantes, além de permitir uma melhoria das condições de vida e da criação de boas expectativas profissionais (BECKER, 1996). 
A partir da década de 1960, coincidindo com a institucionalização da escolarização de massa, outros aspectos da violência no contexto escolar passam a ser abordados. A escola deixa de ser um espaço que afasta a violência e passa a vivenciar suas próprias formas de violência. É dentro dessa abordagem que Charlot (2002, p. 434 - 435) vai conceituar três tipos de violência:

\begin{abstract}
A violência $n a$ escola é aquela que se produz dentro do espaço escolar, sem estar ligada à natureza e às atividades da instituição escolar: quando um bando entra na escola para acertar as contas das disputas que são as do bairro, a escola é apenas o lugar de uma violência que teria podido acontecer em qualquer outro local. Pode-se, contudo, perguntar-se por que a escola, hoje, não está mais ao abrigo de violências que outrora se detinham nas portas da escola.

A violência à escola está ligada à natureza e às atividades da instituição escolar: quando os alunos provocam incêndios, batem nos professores ou os insultam, eles se entregam a violências que visam diretamente a instituição e aqueles que a representam. Essa violência contra a escola deve ser analisada junto com a violência da escola: uma violência institucional, simbólica, que os próprios jovens suportam através da maneira como a instituição e seus agentes os tratam (modos de composição das classes, de atribuição de notas, de orientação, palavras desdenhosas dos adultos, atos considerados pelos alunos como injustos ou racistas...).
\end{abstract}

Apesar dessa conceituação, a violência no contexto escolar expressa nas pesquisas empíricas, nos Estados Unidos, por exemplo, abrange desde mortes, ameaças, lesões corporais, tanto na escola quanto no caminho escola-casa; participação em gangues e uso de drogas por parte de estudantes, bem como os problemas disciplinares, as condições físicas e as medidas de disciplina e de segurança da própria instituição (ROBERS et al, 2012).

Nas escolas inglesas, a violência se relaciona ao comportamento de alunos e à interação aluno - professor. Engloba também comportamentos de pessoas externas à área escolar, tais como venda e consumo de drogas e (ou) criminalidade (DEBARBIEUX; BLAYA, 2002a). Por outro lado, Bélgica, Alemanha, Espanha, Grécia e Suíça, por sua vez, consideram violência escolar apenas os atos dos próprios estudantes, cometidos entre si, contra professores ou contra a escola (DEBERBIEUX; BLAYA, 2002a).

No Brasil, as pesquisas sobre violência escolar começaram a se desenvolver a partir da década de 1980, tendo maior desenvolvimento após os anos de 1990. Tais pesquisas envolvem a violência tanto na escola (violência vivenciada pela comunidade do entorno da escola) quanto à escola, efetivada pelos alunos, sem esquecer a própria violência da escola, isto é, perpetrada pelos próprios estabelecimentos, pelos professores e pelos demais funcionários, conforme mencionam Njaine e Minayo (2003), Abramovay et al. (2002) e Paraná (2010). Sposito (2001), ao analisar as pesquisas sobre a violência escolar realizadas no Brasil no período de 1980 a 2000, observa que esse tema surge como "parceiro do processo de democratização" da sociedade bem como da necessidade de acesso a serviços públicos. Dessa 
forma, a violência no contexto escolar deve ser compreendida levando-se em consideração tanto os seus aspectos objetivos quanto subjetivos.

\subsubsection{Aspectos objetivos}

Em relação aos aspectos objetivos da violência escolar é possível encontrar tanto a violência estrutural quanto a violência simbólica.

Pode-se considerar violência estrutural a falta de acesso à escola. Mas, num país como o Brasil, que alcançou a quase totalidade de escolarização de crianças, esse pode parecer não ser o problema principal. Nesse sentido, é a permanência escolar que passa a ser importante também, principalmente diante da crescente evasão escolar que, no Distrito Federal, chegou a quase 10\% (DISTRITO FEDERAL, 2013a. BRASIL, 2009).

A violência estrutural no contexto escolar também se encontra na pesquisa de TORRES et al. (2013), realizada com mil jovens com idade entre 15 a 19 anos, integrantes do grupo dos $40 \%$ mais pobres da população de duas capitais do Brasil, São Paulo e Recife, que cursavam ou cursaram por, pelo menos, seis meses, o ensino médio em escolas públicas.

A pesquisa apresentou uma escola desorganizada e insegura, com pouca conservação e sujeita a ações de depredação, tanto por parte de alunos como pela comunidade, sendo a insegurança da escola mencionada por $24 \%$ dos alunos. Contudo, tal insegurança "não pareceu emergir da presença de conflitos ou de violência" (TORRES et al., 2013, p. 99) na escola ou na comunidade ao redor. Na realidade, ela é relacionada à conservação da escola, de forma que uma escola segura é vista como uma escola bem cuidada e conservada, enquanto uma escola insegura foi mencionada como a escola depredada.

Outra situação que pode ilustrar a violência estrutural na escola pública está relacionada ao professor. De acordo com a pesquisa acima citada, 47\% dos entrevistados consideravam elevado o "nível de absentismo entre os professores". Contudo, ainda assim o professor foi considerado pela maioria dos entrevistados $(77,2 \%)$ um profissional preocupado “com o aluno e a aprendizagem" (TORRES et al., 2013, p. 109).

Observam-se também as diferenças estruturais no Brasil entre a escola pública, que recebe $82,8 \%$ de estudantes do $9^{\circ}$ ano, e a privada, que recebe $17,2 \%$, conforme a Pesquisa Nacional de Saúde do Escolar - PeNSE (BRASIL, 2013), realizada com 109.104 estudantes do $9^{\circ}$ ano do ensino fundamental, tanto de escolas públicas quanto de escolas privadas, que teve como objetivos:

[...] caracterizar o ambiente escolar e o espaço onde está inserida a escola que abriga os alunos do $9^{\circ}$ ano do ensino fundamental, objeto da pesquisa, aplicar um questionário para investigar questões relacionadas à estrutura da escola, dimensão, 
espaços, equipamentos, práticas, políticas e situações do entorno, e cujas informações pudessem ajudar a caracterizar a situação de exposição a fatores de risco e proteção dos escolares (BRASIL, 2013, p. 12).

Cabe esclarecer que a faixa etária desses estudantes é principalmente de 14 anos $(45,5 \%)$, havendo a seguinte divisão, demonstrada na Tabela 1 :

Tabela 1 - Percentual total de escolares frequentando o 90 ano do ensino fundamental por idade (anos completos) $(\%)$

\begin{tabular}{|c|c|c|c|c|c|}
\hline $\begin{array}{c}\text { Idade / } \\
\text { Local }\end{array}$ & $\begin{array}{c}\text { Menos de } \\
\mathbf{1 3} \text { anos }\end{array}$ & $\mathbf{1 3}$ & $\mathbf{1 4}$ & $\mathbf{1 5}$ & $\begin{array}{c}\mathbf{1 6} \text { ou } \\
\text { mais }\end{array}$ \\
\hline Brasil & 0,8 & 22,1 & 45,5 & 18,4 & 13,2 \\
\hline Centro-Oeste & 0,8 & 17,1 & 49,0 & 20,2 & 12,9 \\
\hline Distrito Federal & 0,7 & 14,6 & 54,3 & 20,1 & 10,2 \\
\hline
\end{tabular}

Entre os diversos achados da pesquisa, há a confirmação acerca de uma maior fragilidade de estudantes de escolas públicas, tanto no aspecto econômico quanto social, em comparação aos de escolas privadas. Mas tal diferenciação não se reveste apenas nesses aspectos. A estrutura das escolas, sua localização em área de risco, a transigência ou não no consumo de cigarro dentro do estabelecimento escolar (mesmo diante da política nacional de proibição), demonstram uma diferenciação entre estabelecimentos privados e públicos que podem remeter a situações de violência estrutural ao prejudicarem principalmente estudantes de escola pública. A Tabela 2 demonstra algumas dessas diferenças a partir dos dados da PeNSE (BRASIL, 2013), no referencial nacional:

Tabela 2 - Comparativo da estimativa percentual por dependência administrativa com indicação do intervalo de confiança de $95 \%$ acerca da situação das escolas no Brasil.

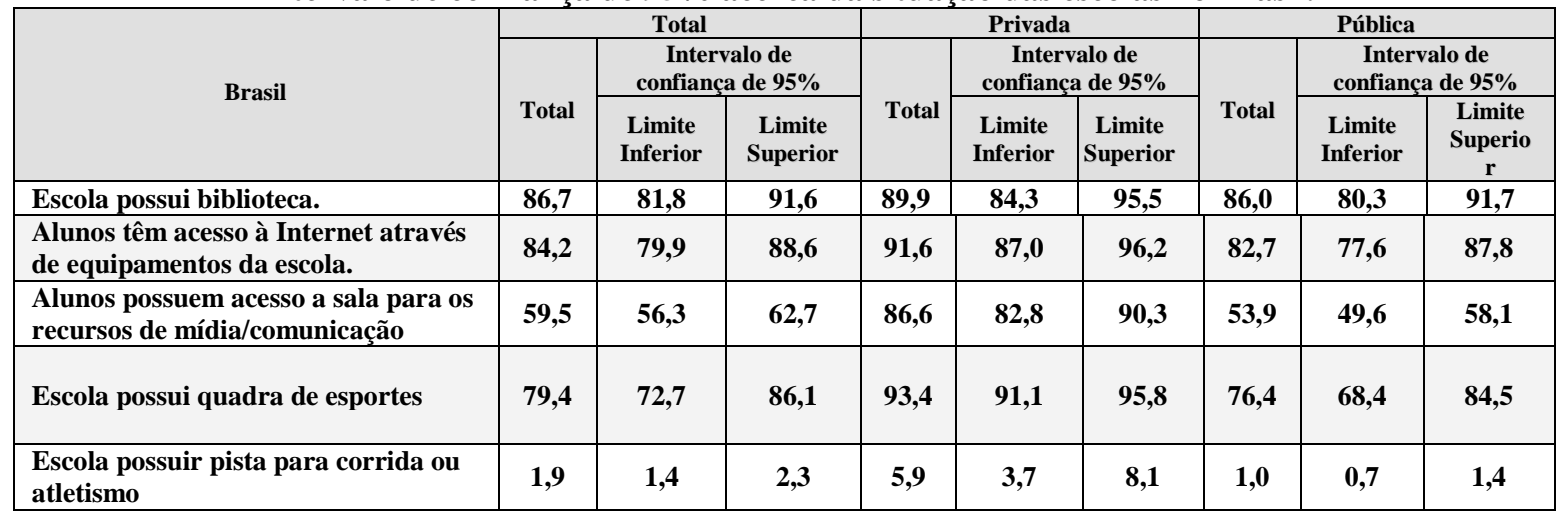




\begin{tabular}{|c|c|c|c|c|c|c|c|c|c|}
\hline \multirow{3}{*}{ Brasil } & \multicolumn{3}{|c|}{ Total } & \multicolumn{3}{|c|}{ Privada } & \multicolumn{3}{|c|}{ Pública } \\
\hline & \multirow{2}{*}{ Total } & \multicolumn{2}{|c|}{$\begin{array}{c}\text { Intervalo de confiança } \\
\text { de } 95 \%\end{array}$} & \multirow{2}{*}{ Total } & \multicolumn{2}{|c|}{$\begin{array}{c}\text { Intervalo de } \\
\text { confiança de } 95 \%\end{array}$} & \multirow{2}{*}{ Total } & \multicolumn{2}{|c|}{$\begin{array}{c}\text { Intervalo de } \\
\text { confiança de } 95,7\end{array}$} \\
\hline & & $\begin{array}{c}\text { Limite } \\
\text { Inferior }\end{array}$ & $\begin{array}{c}\text { Limite } \\
\text { Superior }\end{array}$ & & $\begin{array}{c}\text { Limite } \\
\text { Inferior }\end{array}$ & $\begin{array}{c}\text { Limite } \\
\text { Superior }\end{array}$ & & $\begin{array}{c}\text { Limite } \\
\text { Inferior }\end{array}$ & $\begin{array}{c}\text { Limite } \\
\text { Superior }\end{array}$ \\
\hline $\begin{array}{l}\text { Escola possui pátio para a prática } \\
\text { regular de atividade física com } \\
\text { instrutor. }\end{array}$ & 52,2 & 44,6 & $\mathbf{5 9 , 7}$ & $\mathbf{5 9 , 7}$ & 54,9 & 64,5 & 50,6 & 41,2 & 59,9 \\
\hline $\begin{array}{l}\text { Escola possuir piscina em condições } \\
\text { de uso pelos alunos }\end{array}$ & 6,7 & 5,0 & 8,3 & 35,3 & 30,2 & 40,4 & 0,7 & 0,2 & 1,2 \\
\hline $\begin{array}{l}\text { Escola possui vestiário em condições } \\
\text { de uso para os alunos. }\end{array}$ & 28,5 & 17,1 & 39,9 & 66,8 & 60,7 & 73,0 & 20,5 & 10,3 & 30,7 \\
\hline $\begin{array}{l}\text { Escolas que informaram oferecer } \\
\text { atividades esportivas para os alunos, } \\
\text { fora do horário de aula regular }\end{array}$ & 65,6 & 60,9 & 70,3 & 83,6 & 78,2 & 89,1 & 61,9 & 55,9 & 67,9 \\
\hline $\begin{array}{l}\text { Escolas que informaram possuir } \\
\text { política sobre proibição do uso do } \\
\text { tabaco }\end{array}$ & 89,3 & 85,3 & 93,1 & 84,6 & 75,1 & 94,0 & 90,3 & 87,3 & 93,3 \\
\hline $\begin{array}{l}\text { Escolas que informaram ter } \\
\text { conhecimento de consumo de cigarro } \\
\text { por professores nas suas } \\
\text { dependências }\end{array}$ & 15,8 & 15,0 & 16,6 & 5,9 & 2,5 & 9,2 & 17,8 & 16,0 & 19,7 \\
\hline $\begin{array}{l}\text { Escolar que informaram ter } \\
\text { conhecimento de consumo de cigarro } \\
\text { por alunos }\end{array}$ & 19,6 & 14,8 & 24,3 & 3,3 & 0,2 & 6,4 & 22,9 & 18,6 & 27,2 \\
\hline $\begin{array}{l}\text { A localidade onde a escola está } \\
\text { situada foi considerada, nos últimos } \\
12 \text { meses, área de risco em termos de } \\
\text { violência (roubos, furtos, assaltos, } \\
\text { troca de tiros, consumo de drogas, } \\
\text { homicídios, etc.). }\end{array}$ & 17,9 & 12,7 & 23,1 & 5,5 & 3,9 & 7,1 & 20,4 & 14,9 & 25,9 \\
\hline
\end{tabular}

Fonte: PeNSE (BRASIL, 2013)

Especificamente em relação ao Distrito Federal, a Tabela 3 mostra o mesmo comparativo. Tradicionalmente, o Distrito Federal tem aspectos estruturais favoráveis acima da média nacional. No entanto, aspectos como acesso à Internet, sala de recursos multimídia, atividades esportivas fora do horário normal de aulas bem como a localização das escolas em áreas em situação de risco de violência, demonstram as desvantagens dos estudantes de escolas públicas frente aos de escolas privadas. O resultado dessa realidade é justamente a perpetuação das desigualdades já existentes no contexto social e econômico.

Tabela 3 - Comparativo da estimativa percentual por dependência administrativa com indicação do intervalo de confiança de $95 \%$ acerca da situação das escolas no Distrito Federal.

\begin{tabular}{|c|c|c|c|c|c|c|c|c|c|}
\hline \multirow{3}{*}{ Distrito Federal } & \multicolumn{3}{|c|}{ Total } & \multicolumn{3}{|c|}{ Privada } & \multicolumn{3}{|c|}{ Pública } \\
\hline & \multirow{2}{*}{ Total } & \multicolumn{2}{|c|}{$\begin{array}{c}\text { Intervalo de } \\
\text { confiança de } 95 \% \\
\end{array}$} & \multirow{2}{*}{ Total } & \multirow[b]{2}{*}{$\begin{array}{c}\text { Limite } \\
\text { Inferior }\end{array}$} & \multirow[b]{2}{*}{$\begin{array}{c}\text { Limite } \\
\text { Superior } \\
\end{array}$} & \multirow[t]{2}{*}{ Total } & \multicolumn{2}{|c|}{$\begin{array}{c}\text { Intervalo de confiança } \\
\text { de } 95 \%\end{array}$} \\
\hline & & $\begin{array}{c}\text { Limite } \\
\text { Inferior }\end{array}$ & $\begin{array}{c}\text { Limite } \\
\text { Superior } \\
\end{array}$ & & & & & $\begin{array}{c}\text { Limite } \\
\text { Inferior }\end{array}$ & $\begin{array}{c}\text { Limite } \\
\text { Superior } \\
\end{array}$ \\
\hline Escola possui biblioteca. & $\mathbf{9 2 , 7}$ & 84,7 & 100,0 & 100,0 & 100,0 & 100,0 & $\mathbf{9 0 , 3}$ & 79,7 & 100,0 \\
\hline $\begin{array}{l}\text { Escolares informaram possuir sala } \\
\text { ou laboratório de informática para } \\
\text { uso dos alunos. }\end{array}$ & 91,8 & 83,9 & 99,7 & 94,3 & 83,4 & 100,0 & 90,9 & 81,0 & 100,0 \\
\hline $\begin{array}{l}\text { Escolares têm acesso direto a } \\
\text { computadores (notebooks, } P C \text {, palm, } \\
\text { tablets) da escola na sala de aula. }\end{array}$ & 28,5 & 15,7 & 41,3 & 41,7 & 18,1 & 65,3 & 24,1 & 9,2 & 38,9 \\
\hline Escola possui quadra de esportes & $\mathbf{9 3 , 7}$ & 86,7 & 100,0 & 100,0 & 100,0 & 100,0 & 91,6 & 82,3 & 100,0 \\
\hline $\begin{array}{l}\text { Escola possuir pista para corrida ou } \\
\text { atletismo }\end{array}$ & 2,2 & - & 6,4 & - & - & - & 2,9 & - & 8,6 \\
\hline $\begin{array}{l}\text { Escola possui pátio para a prática } \\
\text { regular de atividade física com } \\
\text { instrutor. }\end{array}$ & 48,5 & 34,0 & 63,0 & 32,5 & 10,1 & 54,9 & 53,9 & 36,4 & 71,4 \\
\hline
\end{tabular}


Cont. Tabela 3 (p. 50)

\begin{tabular}{|c|c|c|c|c|c|c|c|c|c|}
\hline \multirow{3}{*}{ Distrito Federal } & \multicolumn{3}{|c|}{ Total } & \multicolumn{3}{|c|}{ Privada } & \multicolumn{3}{|c|}{ Pública } \\
\hline & \multirow{2}{*}{ Total } & \multicolumn{2}{|c|}{$\begin{array}{c}\text { Intervalo de confiança } \\
\text { de } 95 \%\end{array}$} & \multirow[t]{2}{*}{ Total } & \multicolumn{2}{|c|}{$\begin{array}{c}\text { Intervalo de } \\
\text { confiança de } 95 \%\end{array}$} & \multirow[t]{2}{*}{ Total } & \multicolumn{2}{|c|}{$\begin{array}{c}\text { Intervalo de confiança } \\
\text { de } 95 \%\end{array}$} \\
\hline & & $\begin{array}{c}\text { Limite } \\
\text { Inferior }\end{array}$ & $\begin{array}{c}\text { Limite } \\
\text { Superior }\end{array}$ & & $\begin{array}{c}\text { Limite } \\
\text { Inferior }\end{array}$ & $\begin{array}{c}\text { Limite } \\
\text { Superior }\end{array}$ & & $\begin{array}{c}\text { Limite } \\
\text { Inferior }\end{array}$ & $\begin{array}{c}\text { Limite } \\
\text { Superior }\end{array}$ \\
\hline $\begin{array}{l}\text { Escola possuir piscina em condições } \\
\text { de uso pelos alunos }\end{array}$ & 17,7 & 6,6 & 28,7 & 44,9 & 21,3 & 68,4 & 8,4 & - & 20,2 \\
\hline $\begin{array}{l}\text { Escola possui vestiário em condições } \\
\text { de uso para os alunos. }\end{array}$ & 41,4 & 27,1 & 55,6 & 81,4 & 64,6 & 98,2 & 27,9 & 11,3 & 44,4 \\
\hline $\begin{array}{l}\text { Escolas que informaram oferecer } \\
\text { atividades esportivas para os alunos, } \\
\text { fora do horário de aula regular }\end{array}$ & $\mathbf{5 8 , 5}$ & 44,2 & 72,8 & 96,2 & 88,6 & 100,0 & 45,8 & 28,1 & 63,4 \\
\hline $\begin{array}{l}\text { Escolas que informaram possuir } \\
\text { política sobre proibição do uso do } \\
\text { tabaco }\end{array}$ & $\mathbf{7 7 , 9}$ & 65,9 & 89,8 & 77,6 & 58,4 & 96,8 & $\mathbf{7 8 , 0}$ & 63,4 & 92,5 \\
\hline $\begin{array}{l}\text { Escolas que informaram ter } \\
\text { conhecimento de consumo de cigarro } \\
\text { por professores nas suas } \\
\text { dependências }\end{array}$ & 21,7 & $\mathbf{9 , 5}$ & 33,9 & 6,3 & - & 18,3 & 26,9 & 11,4 & 42,4 \\
\hline $\begin{array}{l}\text { Escolar que informaram ter } \\
\text { conhecimento de consumo de cigarro } \\
\text { por alunos }\end{array}$ & 26,3 & 13,3 & 39,3 & - & - & - & 35,2 & 18,6 & 51,9 \\
\hline $\begin{array}{l}\text { A localidade onde a escola está } \\
\text { situada foi considerada, nos últimos } \\
12 \text { meses, área de risco em termos de } \\
\text { violência (roubos, furtos, assaltos, } \\
\text { troca de tiros, consumo de drogas, } \\
\text { homicídios, etc.). }\end{array}$ & 18,7 & 7,3 & 30,2 & $\mathbf{9 , 0}$ & - & 21,8 & 22,0 & 7,4 & 36,6 \\
\hline
\end{tabular}

Fonte: PeNSE (BRASIL, 2013).

Nas escolas encontra-se também a violência simbólica no que se refere ao processo pedagógico que, em si mesmo, pode ser violento ao se constituir na reprodução dos valores de um grupo dominante. Nesse sentido, tal processo pode ser uma violência quando exclui e desconsidera a carga cultural que crianças e adolescentes dos estratos mais baixos receberam até então (e continuam recebendo fora do contexto escolar). Ao excluir tais valores, impõe, por outro lado, a cultura dominante de forma arbitrária, o que serve, prioritariamente, para manter o status quo, perpetuando um sistema baseado no privilégio e na desigualdade (BOURDIEU; PASSERON, 1975). Para os autores, o resultado dessa violência é a rejeição à escola pelos que não são bem sucedidos e o crescimento dos problemas disciplinares.

Um achado interessante encontra-se na pesquisa de Torres et al. (2013) ao mencionar que alguns estudantes não gostam e não vêem utilidade na escola; $20 \%$ só a frequentam para conseguir o diploma. É com relação a essa situação que Illich (1985, p. 16) relata que o próprio processo de escolarização tende a produzir essa discrepância:

Ela [a escola] os escolariza para confundir processo com substância. Alcançado isto, uma nova lógica entra em jogo: quanto mais longa a escolaridade, melhores os resultados; ou, então, a graduação leva ao sucesso. O aluno é, desse modo, «escolarizado» a confundir ensino com aprendizagem, obtenção de graus com educação, diploma com competência, fluência no falar com capacidade de dizer algo novo. Sua imaginação é «escolarizada» a aceitar serviço em vez de valor.

Daí a principal razão para a frequência escolar ser a sociabilidade: encontrar os amigos, conviver com as pessoas, fazer brincadeiras. 
Isso explica, por um lado, a predominância de "bagunça e zoeira" nas escolas. Conforme Torres et al. (2013, p. 106), trata-se de uma situação de "tratamento interpessoal mediado por brincadeiras e relações de jocosidade" comum nas relações entre jovens. Como o principal objetivo de ir para a escola é "encontrar os amigos" vigora uma forma de tratamento informal, cheio de brincadeiras, que impede o desenvolvimento das aulas e "contribui, positivamente, para o abandono" escolar, ainda que não de uma forma definitiva.

Quanto a isso chama a atenção o fato de que, para $77 \%$ dos entrevistados na pesquisa de Torres et al. (2013) são comuns situações de "bagunça e zoeira", de modo a atrapalhar as aulas, nas escolas por eles frequentadas. De acordo com a pesquisa, essa situação também é percebida por $76,7 \%$ dos gestores escolares.

"Zoeira e bagunça", no entanto, em geral não se revestem de violência, sendo apenas uma resposta à violência simbólica e estrutural consubstanciada na rejeição aos valores escolares, bem como a ante-sala de uma outra violência estrutural: o abandono escolar. Com isso, elas integram um conflito escolar. Mas há também outra consequência à rejeição à escola: a instituição da violência subjetiva.

\subsubsection{Aspectos subjetivos}

A violência subjetiva, no contexto escolar, pode se configurar na violência à escola, isto é, um ataque à instituição e àqueles que a representam (professores, gestores, funcionários) ou na entrada da violência na escola, ou seja, o ingresso de uma violência que é externa e que passa a acontecer dentro dos muros escolares (CHARLOT, 2002).

O termo violência, para Charlot (2002, p. 437), é reservado "ao que ataca a lei com o uso da força ou ameaça usá-la: lesões, extorsão, tráfico de drogas, insultos graves”. É o que Abramovay et al. (2002. 2005. 2005a. 2009) e Abramovay e Rua (2002) vão chamar de "violências duras". Não se confunde, portanto, com as transgressões e rebeldias dos estudantes, relacionadas a não realização de trabalhos escolares ou absenteísmo, por exemplo, nem com as incivilidades, isto é, a quebra das regras da boa convivência, como bagunça, xingamento, desrespeito.

Contudo, tal diferenciação é muito mais para fins didáticos. Na realidade da instituição escolar atual, violências ou incivilidades convivem entrelaçados nos comportamentos cotidianos de alunos ou professores, não sendo possível, muitas vezes, dissociar onde começa um ou outro. Isso é considerado por Charlot (2002), que opta por focar as incivilidades, deixando o conceito de violência afeito apenas ao que se relaciona ao crime. 
A razão para tanto seria o fato de que as chamadas incivilidades sempre existiram no ambiente escolar, fazendo parte, inclusive, do processo de socialização realizado pela escola. As demais violências não se relacionam diretamente a esse contexto e precisariam ser dele dissociadas.

Debarbieux (2006), por outro lado, considera que todos os atos merecem atenção como violência, desde os delitos qualificados na legislação penal quanto as incivilidades e o "sentimento de violência" expresso pelas vítimas. Para o autor, o estudo da violência escolar inclui as chamadas microviolências, isto é, as incivilidades ou ações cotidianas, não necessariamente criminosas, às vezes até banais, mas que causam sofrimento e se tornam violência pela principal característica de "acumulação, repetição, desgaste e opressão" (Debarbieux, 2006, p. 130).

Há críticas a essa ampliação. Ao se incluir as incivilidades e transgressões comuns à escola como violência pode-se estar impondo uma tentativa de exclusão e abafamento de todo conflito no contexto escolar e justificando ações de pura repressão mesmo a comportamentos que podem ser considerados expressões normais de resistência à instituição e ao processo de socialização (CHARLOT, 2002. FISCHER, 2010).

Assim consideram Debarbieux e Blaya (2002) quando dizem que o reconhecimento dos comportamentos agressivos e violentos dos estudantes tem sido feito por pesquisadores principalmente a partir de incentivos da mídia e de sindicatos de professores. Isso quer dizer que os questionamentos dos autores se dão sobre quem define o que é um comportamento adequado e, ainda, sobre a concentração desse movimento apenas entre os alunos, esquecendo-se que a instituição tem também a capacidade de influir tanto no comportamento quanto no clima em sala de aula.

É nesse sentido que, no Brasil, Scarlato e Silva (2011), em pesquisa sobre o contexto do estudo de teses e dissertações sobre violência escolar entre 2001 a 2009, concluíram que a quase totalidade das investigações (92\%) centram-se na violência dos estudantes, havendo poucos trabalhos $(8 \%)$ que tratam da violência dos professores.

Uma crítica final relaciona-se ainda à possibilidade de a ampliação do conceito colocar como responsabilidade da escola violências que nada tem a ver com a natureza ou as finalidades escolares.

Debarbieux reconhece tais críticas e as sintetiza da seguinte forma:

Se expandirmos a definição de violência, correremos dois riscos: primeiramente, o risco epistemológico de hiperampliar o problema até torná-lo impensável, e em segundo lugar, o risco político de vir a criminalizar padrões comportamentais comuns, ao incluí-los na definição de violência (2006, p. 60). 
No entanto, os argumentos do autor são a favor da extensão, situando-se em três eixos: metodológico, de controle e sobre os sujeitos. O primeiro refere-se ao fato de que a violência não é um todo indivisível, mas um fenômeno complexo localizado num espaçotemporal específico, daí a necessidade de se multiplicarem seus pontos de vistas (indicadores) sobre causas, formas de atuação e de prevenção, o que só vem com a ampliação do conceito.

O segundo eixo responde ao risco do aumento da repressão. Quanto a isso, o autor lembra que a violência no contexto escolar é múltipla, complexa, densa e com causas tanto exógenas (bairro, sistema econômico, falhas familiares ou de políticas públicas) quanto endógenas (organização ou desorganização da escola). Diante disso, é possível que, com a compreensão de suas causas sejam mais prontamente desenvolvidas ações de prevenção, mas quem se necessária, a repressão não é algo a ser temido.

Por fim, Debarbieux (2006, p. 85) lembra da necessidade de se olhar para os sujeitos dessas violências, pois, a verdade sobre "um fenômeno social também resulta no significado que os sujeitos - na posição de sujeitos sociais - dão aos eventos e aos ato". Assim, o autor considera que a história de todas as violências é a história do reconhecimento de suas vítimas. Teria sido assim com o assédio moral ou com a violência doméstica, por exemplo, só surgidas como crime após a consideração da fala de suas vítimas. Por outro lado:

\footnotetext{
Os levantamentos de vitimização mostram [...] como o stress acumulado da microviolência pode ter um efeito tão desestabilizador quanto um único ataque grave, e que a violência é tanto uma questão de opressão diária quanto de atos brutais e espetaculares. Os levantamentos sobre a intimidação por colegas ganham significado com as pesquisas sobre as causas do suicídio entre adolescentes, e a correlação entre as taxas de suicídio e a ocorrência de intimidação há muito já ficou demonstrada (DEBARBIEUX, 2006, p. 74).
}

Dessa forma, a não ampliação do conceito pode causar o abandono das vítimas e a desconsideração dos efeitos da violência: exclusão, abandono escolar, aumento da gradação, comportamentos de risco e suicídio (DEBARBIEUX; BLAYA, 2002. FISCHER, 2010).

Daí a necessidade da ampliação de forma a englobar as próprias relações de convivência. Pelos mesmos motivos, tanto violências relacionadas a crimes e ofensas à lei, quanto transgressões (comportamentos contrários às normas institucionais da escola) assim como incivilidades (quebras de regras de boa convivência) serão neste estudo consideradas violências no contexto escolar. 


\subsubsection{A convivência na escola}

De acordo com a pesquisa de Torres et al. (2013) a maioria dos estudantes $(57,6 \%)$ considerava que era sempre bem tratada, ou quase sempre, pelos colegas. Somente $7,2 \%$ afirmaram que sempre ou quase sempre se sentiram humilhados por provocações; pouco mais de $8 \%$ admitiram conflitos com professores, diretores e coordenadores, sendo que $11,1 \%$ disseram haver algum conflito com colegas. Não houve uma conceituação precisa de "conflito" na pesquisa.

Tais dados são confirmados pela pesquisa PeNSE (BRASIL, 2013), sendo que $62,8 \%$ das alunas do $9^{\circ}$ ano do ensino fundamental declararam ter sido bem tratadas por seus colegas. Entre os meninos, o percentual foi de 52\%. Também a pesquisa "Bullying escolar no Brasil" (FISCHER, 2010) apresenta que os estudantes em geral se sentem bem nas escolas:

Tabela 4 - Como estudantes se sentem no ambiente escolar

\begin{tabular}{|l|l|l|l|l|l|}
\hline Como se sente & Nunca & $\grave{\text { As vezes }}$ & Sempre & Em branco & Total \\
\hline Acolhido & $12,7 \%$ & $40,8 \%$ & $43,3 \%$ & $3,2 \%$ & $\mathbf{1 0 0 \%}$ \\
\hline Amado & $9,3 \%$ & $38,7 \%$ & $49,3 \%$ & $2,8 \%$ & $\mathbf{1 0 0 \%}$ \\
\hline Angustiado & $50,2 \%$ & $43,6 \%$ & $3,2 \%$ & $3,0 \%$ & $\mathbf{1 0 0 \%}$ \\
\hline Bem & $4,8 \%$ & $36,1 \%$ & $56,8 \%$ & $2,3 \%$ & $\mathbf{1 0 0 \%}$ \\
\hline Com medo & $57,5 \%$ & $36,3 \%$ & $3,2 \%$ & $3,1 \%$ & $\mathbf{1 0 0 \%}$ \\
\hline Excluído & $57,8 \%$ & $33,5 \%$ & $5,7 \%$ & $3,0 \%$ & $\mathbf{1 0 0 \%}$ \\
\hline Humilhado & $69,0 \%$ & $26,0 \%$ & $2,6 \%$ & $2,3 \%$ & $\mathbf{1 0 0 \%}$ \\
\hline Maltratado & $70,3 \%$ & $23,8 \%$ & $2,7 \%$ & $3,2 \%$ & $\mathbf{1 0 0 \%}$ \\
\hline Sozinho & $54,9 \%$ & $38,8 \%$ & $4,0 \%$ & $2,4 \%$ & $\mathbf{1 0 0 \%}$ \\
\hline
\end{tabular}

Fonte: Fischer (2010, p. 22-23)

Assim, um sentimento permanente de humilhação, solidão, exclusão e de maus tratos é baixo em comparação aos bons sentimentos, o que não significa que não ocorram "às vezes" nem a inexistência de violência subjetiva no ambiente escolar.

A pesquisa PeNSE (BRASIL, 2013) também indicou que 7,3\% dos alunos do $9^{\circ}$ ano do ensino fundamental teriam se envolvido, nos 30 dias que a antecederam, em brigas com armas brancas, sendo que há prevalência de estudantes das escolas públicas $(7,6 \%)$ em relação às escolas privadas $(6,2 \%)$. Essa diferença se repete quanto ao Distrito Federal, no qual $8,2 \%$ dos estudantes se envolveram em brigas com armas brancas, sendo 8,7\% nas escolas públicas e $7 \%$ nas escolas particulares.

Quanto a brigas com armas de fogo: 6,4\% dos estudantes brasileiros no $9^{\circ}$ ano do ensino fundamental teriam se envolvido nos 30 dias que antecederam a pesquisa. No Distrito Federal, esse percentual é de 7,9\%, acima da média nacional, sendo $8,8 \%$ dos estudantes de escolas públicas e 5,5\% dos estudantes de escolas particulares.

Nos 12 meses anteriores à pesquisa 10,3\% dos alunos teriam sido "seriamente feridos" uma ou mais vezes, não havendo, contudo, uma conceituação dessa percepção. Em 
relação à dependência administrativa, foram 10,6\% nas escolas públicas e 8,8\% nas escolas privadas. No Distrito Federal, o percentual foi 9,2\%, sem diferenças entre os tipos de escola.

Já na pesquisa "Bullying escolar no Brasil” (FISCHER, 2010, p. 02), que aplicou questionário em 5.168 alunos e realizou 14 "grupos focais com 55 alunos, 14 pais/responsáveis e 64 técnicos, professores ou gestores de escolas localizadas nas capitais pesquisadas" em escolas públicas e privadas localizadas em capitais ou municípios do interior de todas as regiões geográficas do país, $70 \%$ da amostra que responderam haver presenciado cenas de agressão entre colegas durante o ano escolar de 2009. Enquanto isso, 30\% declararam haver vivido ao menos uma situação violenta no mesmo período.

Mas um dos temas que mais tem chamado a atenção na mídia é o termo bullying, ou intimidação por pares. Conforme Fischer (2010, p. 04) trata-se do conjunto de atitudes e ações de maus tratos entre colegas ocorridas com frequência superior a três vezes durante o ano letivo. Nesse sentido, possui como características a repetição e uma relação desigual de poder entre quem faz e quem sofre o ato. Para a pesquisa PeNSE ele é:

[...] comportamentos com diversos níveis de violência, que vão desde chateações inoportunas ou hostis até fatos francamente agressivos, sob forma verbal ou não, intencionais e repetidas, sem motivação aparente, provocados por um ou mais alunos em relação a outros, causando dor, angústia, exclusão, humilhação, discriminação, entre outras sensações. [...] Trata-se de situações em que se constatam relações de poder assimétricas entre agente(s) e vítima(s), nas quais se tem dificuldade de defesa (BRASIL, 2013, p. 70).

Diante disso, pode-se considerar que o bullying envolve como elementos:

a. uma situação de maus tratos;

b. direcionada a uma vítima específica;

c. duradoura;

d. dentro de uma relação assimétrica de poder.

O bullying é um fenômeno mundial, a ponto de a pesquisa Healthy Behavior in School Aged - HBSC estimar que 13\% dos alunos com 11 anos sofrerem por, no mínimo, duas vezes nos dois meses anteriores à pesquisa (CURRIE et al., 2012).

No Brasil, de acordo com Fischer (2010, p. 02) ele teria sido praticado e sofrido por $10 \%$ dos pesquisados, sendo mais frequente entre adolescentes de 11 a 15 anos de idade e no $6^{\circ}$ ano do ensino fundamental.

Mais de 34,5\% da amostra de vítimas do sexo masculino foram vítimas de maus tratos ao menos uma vez no ano anterior, sendo 12,5\% vítimas de bullying. Nesse sentido, cabe esclarecer que a pesquisa diferencia bullying de maus tratos em relação à frequência das ações, ou seja, o conjunto de ações é o mesmo, mas para o bullying é 
necessária uma frequência mínima de 03 vezes, ao passo que já são considerados maus tratos ações que ocorram mesmo 01 ou 02 vezes.

O fenômeno do bullying tem predominância na região Sudeste, com 15,5\% de vítimas, sendo seguida pela região Centro-Oeste $(11,7 \%)$, Sul $(8,4 \%)$; Norte $(6,2 \%)$ e região Nordeste $(5,4 \%)$. Em relação ao Centro-Oeste, no entanto, cabe esclarecer que a pesquisa foi realizada apenas em Brasília, Brazlândia e Samambaia.

Ao ser relacionar aos agressores, tem-se que, no Brasil, 10\% da amostra de alunos afirmam ter praticado bullying ao passo que $29 \%$ afirma ter praticado, alguma vez, maus tratos. O Distrito Federal (Centro-Oeste) lidera esse ranking, com 14\% da amostra declarando haver praticado bullying (FISCHER, 2010). Em relação às vítimas, a Tabela 5 mostra os casos de bullying e maus tratos por região e duração:

Tabela 5 - Vitimização de bullying e maus tratos, por frequência, duração e região.

\begin{tabular}{|l|r|r|r|r|r|r|}
\hline $\begin{array}{l}\text { Frequência de maus } \\
\text { tratos }\end{array}$ & Centro-Oeste & Nordeste & Norte & Sudeste & Sul & Total \\
\hline Não fui maltratado & $66,7 \%$ & $77,3 \%$ & $77,8 \%$ & $59,6 \%$ & $76,0 \%$ & $70,9 \%$ \\
\hline Fui 1 ou 2 vezes & $20,3 \%$ & $15,8 \%$ & $14,8 \%$ & $23,9 \%$ & $14,6 \%$ & $18,2 \%$ \\
\hline Fui de 3 a 6 vezes & $4,0 \%$ & $1,9 \%$ & $2,6 \%$ & $6,3 \%$ & $3,8 \%$ & $3,8 \%$ \\
\hline 1 vez por sem & $1,5 \%$ & $1,0 \%$ & $1,2 \%$ & $2,0 \%$ & $1,1 \%$ & $1,4 \%$ \\
\hline Várias vezes por sem & $3,8 \%$ & $1,0 \%$ & $1,0 \%$ & $4,9 \%$ & $2,4 \%$ & $2,7 \%$ \\
\hline Todos os dias & $2,4 \%$ & $1,5 \%$ & $1,4 \%$ & $2,3 \%$ & $1,1 \%$ & $1,7 \%$ \\
\hline Em branco & $1,3 \%$ & $1,6 \%$ & $1,1 \%$ & $1,1 \%$ & $1,0 \%$ & $1,2 \%$ \\
\hline Total geral & $100 \%$ & $100 \%$ & $100 \%$ & $100 \%$ & $100 \%$ & $100 \%$ \\
\hline
\end{tabular}

Fonte: FISCHER, 2010, p. 25.

Parece que nem sempre há motivos ou razão para sofrer ou praticar o bullying. É o que revelou a pesquisa ao mostrar que $12,97 \%$ dos estudantes entrevistados informaram não saber o motivo para o assédio. Os demais consideram como motivações para os maus tratos: desejo de popularidade dos autores (16,84\%); brincadeiras (11,59\%); desejo de dominação dos autores $(9,49 \%)$; autores são mais fortes $(9 \%)$; ausência de reação das vítimas $(8,16 \%)$; porque a vítima é diferente $(6,78 \%)$; ausência de punição $(6,52 \%)$; autores se sentem provocados $(4,98 \%)$ e ainda porque a vítima merece (3,73\%) (FISCHER, 2010).

Além disso, o bullying é minimizado tanto por professores e gestores, quanto pelos estudantes e pais. Como a maioria dos casos refere-se a agressões verbais praticadas por um aluno contra outro, as ações são consideradas normais entre adolescentes e crianças.

Em relação aos gestores e professores, a pesquisa indica que eles não consideram o problema como sua responsabilidade nem como parte da função escolar, havendo, por outro lado, a responsabilização da família. Um dos dados que demonstram a negligência escolar em relação ao bullying é justamente o fato de que ele ocorre às claras, em 
locais sob supervisão de professores, gestores e demais funcionários, ou seja, na sala de aula, com ou sem a presença de professor, nos pátios de recreios e corredores escolares, tal como indica a Tabela 6 a seguir:

Tabela 6 - Espaço de manifestação do bullying

\begin{tabular}{|l|c|c|}
\hline Espaço da escola & Quantidade & Percentual \\
\hline Não fui maltratado & 3572 & $57,0 \%$ \\
\hline Na sala de aula sem professor & 800 & $12,8 \%$ \\
\hline Na sala de aula com professor & 548 & $8,7 \%$ \\
\hline No pátio de recreio & 495 & $7,9 \%$ \\
\hline Nos corredores & 329 & $5,3 \%$ \\
\hline Outros & 173 & $2,8 \%$ \\
\hline Nos portões da escola & 115 & $1,8 \%$ \\
\hline No banheiro & 92 & $1,5 \%$ \\
\hline No trajeto escola-casa & 77 & $1,2 \%$ \\
\hline No transporte escolar & 62 & $1,0 \%$ \\
\hline Total geral & 6263 & $100,0 \%$ \\
\hline
\end{tabular}

Fonte: FISCHER, 2010, p. 40.

No que se refere aos pais, criticam a escola, os professores e os gestores quanto à falta de punição de agressores e de proteção às vítimas, de forma que:

Comparando-se as ênfases dos discursos de pais e professores, parece haver uma situação em que cada um destes grupos esta "jogando" para o outro a responsabilidade de evitar episódios de maus tratos no ambiente escolar. Diferentemente dos professores e gestores, que só assumiram a responsabilidade da escola após serem questionados sobre isso, os pais sinalizaram de forma espontânea a sua própria responsabilidade por tais ocorrências. Percebe-se, no entanto, que quando estimulados à reflexão, professores e gestores foram capazes de perceber o papel da escola no desenvolvimento e/ou na manutenção de comportamentos violentos (FISCHER, 2010, p. 35).

Assim, em relação ao bullying a pesquisa evidenciou ainda que não há ações de prevenção, controle ou correção e a escola não se mostra preparada para administrar adequadamente tais situações. Contudo, ele tende a ser apenas o primeiro passo em direção a ações mais violentas, sinalizando a importância de seu enfrentamento e da busca de prevenção. Ademais, a pesquisa indica que vítimas ou autores tendem a perder o interesse em estudar, o que se relaciona a pesquisas sobre consequências da violência no contexto escolar.

As violências no contexto escolar não se referem apenas aos alunos, mas também englobam os adultos, isto é, professores, gestores e demais funcionários escolares. A violência simbólica realizada é perpetrada por tais atores.

Contudo, salta aos olhos o fato de violência no contexto escolar ser centrada no comportamento do aluno. Essa percepção já foi dada por Blaya (2002) e, no Brasil, por Scarlato e Silva (2011), conforme tópico anterior, onde quase $92 \%$ dos trabalhos acadêmicos 
sobre o tema, no período de 2001 a 2009, centram-se na violência dos estudantes. Apesar disso, ao analisar as pesquisas sobre o tema, Scarlato e Silva concluem que:

[...] professores/as de diferentes estados brasileiros, diferentes gêneros, diferentes níveis de ensino, que ministram diferentes disciplinas, em sua maioria, cometem violência contra seus/as alunos/as em sala de aula. Além disso, eles/as acreditam na legitimidade de seus atos (SCARLATO e SILVA, 2011, p.10).

Um dos trabalhos sobre a violência psicológica realizada por professores é o de Koehler (2003), com a participação de 516 alunos de escolas públicas e privadas da Bahia. A autora concluiu que tal violência é uma realidade do cotidiano escolar ao estar presente na vida de 94,6\% da amostra, sendo que 94\% dos alunos são da rede pública e $96 \%$ da rede particular. Nesse sentido, a violência se consubstancia em atos como gritar $(32,8 \%)$, humilhar os alunos $(28,1 \%)$ e fazer comparações depreciando $(16,6 \%)$.

A atuação do professor e da escola como um todo tem o condão de influenciar a vida dos estudantes do lado de fora do contexto escolar, suas perspectivas de trabalho. Assim, sua atuação é essencial para o desenvolvimento da convivência na escola, no desenvolvimento do clima escolar e, com isso, de formas tanto de prevenção como de gerenciamento da violência presente.

\subsection{Formas de prevenir e lidar com a violência no contexto escolar}

A partir do desenvolvido até aqui, percebe-se que a violência na escola é uma realidade. Em qualquer contexto que se vá observar ela pode ser encontrada, influenciando a convivência e a qualidade do ensino, não havendo fórmulas mágicas para se lidar.

Charlot (2002, p. 439) considera que incidentes violentos existem onde há grande nível de tensão, de forma que "uma simples faísca que sobrevenha (um conflito, às vezes menor), provoca a explosão (o ato violento)". Diante disso, as ações para lidar com a violência devem ser direcionadas às tentativas de diminuir tais fontes de tensão, relacionadas às possibilidades de protagonismo e participação de jovens e à construção da convivência.

Já Debarbieux considera que não há uma causa única para a violência: ela é multicausal, plural, e tanto formas de prevenção quanto de gerenciamento devem considerar esses pontos. Isso significa não ser possível trabalhar, ao mesmo tempo, com todas elas, e sim enfocar ações que possam lidar com os fatores de risco de violência escolar. Fator de risco é um acontecimento ou condição que aumenta "a probabilidade de uma criança ou adolescente desenvolver distúrbios emocionais ou de comportamento" (DEBARBIEUX, 2006, p. 141). São os indicadores que apresentam os grupos sensíveis que demandariam políticas públicas 
específicas. Não é uma abordagem determinista, mas probabilística, relacionada a riscos individuais, familiares, escolares ou do meio social.

O problema de se lidar apenas com fatores de risco, em especial os que se relacionam às atitudes individuais, é o de se considerar que relação significa "causação". Um exemplo disso é a relação entre delinquência e fraco desempenho acadêmico. Fraco desempenho acadêmico é um dos fatores de risco dados por Debarbieux (2006) para a delinquência. Contudo, pode-se questionar se o fraco desempenho já não é uma consequência de violências anteriores que, essas, sim, são as causas da delinquência juvenil. Para demonstrar essa ideia, a Tabela 7 apresenta alguns fatores de risco elaborados pelo autor a partir de pesquisas sobre o tema. Para esta dissertação foram considerados apenas os fatores considerados com "forte efeito de fator de risco" por pelo menos duas pesquisas mencionadas:

Tabela 7 - Fatores de risco para violência entre crianças e adolescentes

\begin{tabular}{|l|}
\hline \multicolumn{1}{|c|}{ Fatores de Risco Individual } \\
\hline Temperamento (agressividade) \\
\hline Hiperatividade / déficit de atenção \\
\hline Iniciação precoce à violência \\
\hline Gênero (masculino) \\
\hline Abuso precoce de drogas e álcool \\
\hline \multicolumn{2}{|c|}{ Fates de risco familiares } \\
\hline Criminalidade parental \\
\hline Maus tratos / abuso sexual \\
\hline Laços fracos entre pais e filhos \\
\hline Falta de empenho parental \\
\hline Práticas punitivas excessivas ou flutuantes \\
\hline \multicolumn{1}{|c|}{ Fatores de risco associados à escola } \\
\hline Insucesso escolar \\
\hline Problemas disciplinares frequentes \\
\hline Fraco empenho nas atividades escolares \\
\hline \multicolumn{1}{|c|}{ Fatores de risco ligados aos pares } \\
\hline Pares delinquentes \\
\hline Membros de gang \\
\hline Fatores de risco ligados ao meio social \\
\hline Pobreza \\
\hline Desorganização comunitária \\
\hline Exposição à violência e ao racismo \\
\hline
\end{tabular}

Fonte: Debarbieux (2006).

É por isso que, conjuntamente à análise dos fatores de risco, deve-se realizar uma análise contextual, que engloba o ambiente comunitário (vizinhança, serviços públicos, práticas de entreajuda na comunidade, isto é, o "capital social"), a composição sóciodemográfica do grupo escolar e as características institucionais (existência de trabalho colaborativo, forma de gestão, participação real dos alunos nas decisões), além de regras disciplinares e práticas punitivas para se trabalhar as causas da violência (Debarbieux, 2006). 
Com isso, é possível elaborar políticas públicas e programas que possam lidar com a violência existente bem como prevenir novas situações ao permitir desenvolver fatores de proteção, que atuam de forma contrária aos fatores de risco.

Nesse sentido, Debarbieux (2006) considera que os mais fortes fatores de proteção contra as violências do contexto escolar são relacionados ao desenvolvimento de um sentimento de pertencimento à comunidade, que surge a partir de um estilo cooperativo de trabalho, da existência de relações fraternas, da liderança positiva dos adultos, do sentimento de justiça na aplicação de regras e punições e da expectativa de sucesso dos alunos.

Com isso, é possível se considerar que o problema da escola atual talvez não seja exatamente como fazer desaparecer a violência, mas como desenvolver fatores de proteção por meio da regulação dos conflitos inerentes à convivência. Daí que pensar também no conflito e não apenas na violência passa a ser importante para a proteção contra a violência no contexto escolar. 


\section{DO CONFLITO}

O ser humano vive em situações de conflito a todo o momento, mesmo em sonhos. O conflito é, assim, intrínseco à vida e, portanto, presente nos vários contextos do cotidiano. Sendo assim, é compreensível que haja vários conceitos e autores a lidar com essa temática.

Pasquino (1995, p. 225), por exemplo, cientista político, conceitua conflito como "uma forma de interação entre indivíduos, grupos, organizações e coletividades que implica choques para o acesso e a distribuição de recursos escassos", sendo tais recursos tanto bens materiais quanto imateriais, como honra, poder ou prestígio. Dentro dessa conceituação, conflito antagoniza-se à cooperação, outra forma de interação entre indivíduos que, ao invés do choque de interesses, implica auxílio mútuo em busca de um fim comum.

Para Deutsch (2004), dentro da teoria dos conflitos, o conflito pode ser encontrado em ambientes cooperativo ou competitivo, pois apesar de uma competição envolver um conflito, nem todo conflito envolve uma competição.

Dentro da concepção da teoria dos jogos, Almeida (2003) explica que o conflito é uma dada situação em que as partes procuram maximizar seus ganhos, podendo, para tanto, utilizar estratégias de cooperação ou de competição. Na perspectiva expressa pelo autor, se, diante de um conflito, todos os envolvidos buscarem o melhor para si e para os outros, o ganho de todos é superior do que se cada um buscar apenas o melhor para si.

Da mesma forma, Costa (2003) - numa crítica à concepção tradicional do direito acerca do conflito, que o veria como uma disputa de interesses - considera o conflito como tensão a exigir diferentes e específicas formas de enfrentamento. Diante disso, o autor afasta a ideia de conflito como disputa, pois, para ele, tal ideia pode levar à concepção de que todo conflito pode ser resolvido por via de um acordo, o que não seria verdade:

[...] a identificação do conflito com a disputa acerca de um bem (ou de uma determinada combinação de bens) é uma concepção demasiadamente restrita da dimensão conflituosa da vida em sociedade. E a insistência no acordo como forma única de resolução de conflitos é demasiadamente ligada à noção de que os conflitos são aquilo que se precisa anular na sociedade (COSTA, 2003, p. 162).

Já Rancière (1996, p. 12) conceitua o conflito a partir de uma abordagem da filosofia política como um desentendimento, ou seja, uma discussão acerca de um objeto "e sobre a condição daqueles que o constituem como objeto". O desentendimento se dá, assim, em relação à palavra em si (o objeto) e sobre o direito à palavra (a condição dos que conflitam). Não é um desconhecimento em relação ao objeto, nem um mal entendido: 
Os casos de desentendimento são aqueles em que a disputa sobre o que quer dizer falar constitui a própria racionalidade da situação de palavra. Os interlocutores então entendem e não entendem aí a mesma coisa nas mesmas palavras. Há todas as espécies de razão que um $\mathrm{X}$ entenda e não entenda ao mesmo tempo um Y: porque, embora entenda claramente o que o outro diz, ele não vê o objeto do qual o outro lhe fala; ou então porque ele entende e deve entender, vê e quer fazer ver um objeto diferente sob a mesma palavra, uma razão diferente no mesmo argumento.

Assim, o lugar privilegiado do desentendimento é a política, vista então como espaço de pluralidade, de igualdade, como "pressuposição da igualdade de qualquer pessoa com qualquer pessoa" (RANCIÈRE, 1996, p. 31). A política, nesse sentido, tem em sua própria racionalidade o desentendimento. Ela existe porque a ordem social não é natural, e sim cultural, daí os seres humanos precisarem viver e conviver em sociedade.

Para o reconhecimento do conflito, assim, é preciso que cada um dos lados envolvidos compreenda que o outro é igual, que ele tem o espaço da fala. Ou seja, que haja o reconhecimento da condição de pluralidade entre os envolvidos. E isso mesmo numa relação de mando e obediência, pois:

[...] para obedecer uma ordem, são necessárias [...] duas coisas: deve-se compreender a ordem e deve-se compreender que é preciso obedecer-lhe. E, para fazer isso, é preciso você já ser o igual daquele que manda (RANCIÈRE, 1996, p. $31)$.

O conflito, então, é um fato, uma contradição, um desentendimento que nasce da interação, da pluralidade, entre iguais. Isso se dá porque ele se relaciona à própria vida em sociedade, à convivência com o outro. Nesse sentido, se está a afastar, a partir de então, qualquer interpretação psíquica acerca do tema, que dê origem ao que Pasquino (1995) vai chamar de conflito intrapessoal. Não que esse conflito não seja importante, mas apenas porque não se relaciona aos aspectos da pluralidade do conflito interpessoal e social. Diante disso, cabe considerar como transformar os conflitos de forma a tornar as relações cooperativas ao invés de competitivas, mas antes necessário é discorrer sobre as concepções de conflito.

\subsection{Uma concepção acerca do conflito}

Tradicionalmente há duas grandes concepções acerca do conflito.

A primeira considera o conflito uma ruptura do consenso e da harmonia intrínsecos à sociedade (JARES, 2002. BUSH e FOLGER, 2005). Pasquino (1995) informa que se parte do pressuposto de que a natureza humana e a sociedade são harmônicas e que o progresso e o desenvolvimento advêm de relações consensuais. Assim, diante do conflito, há a tentativa de sua eliminação, o que pode significar a busca a qualquer custo de um acordo ou 
uma solução heteronômica, isto é, dada por um terceiro (PASQUINO, 1995; BUSH e FOLGER, 2005; SIX, 2001; COSTA, 2003).

A segunda concepção compreende que a sociedade não é naturalmente harmônica e que o conflito é intrínseco a ela e ao próprio ser humano. Nesse sentido, ele é motor de desenvolvimento, seja individual, relacionado ao conflito intrapessoal, psíquico, seja social, no que se refere ao conflito interpessoal ou coletivo. Assim, a eliminação do conflito, além de indesejada, é também impossível, porque advém das contradições humanas e da vida em comunidade (PASQUINO, 1995. JARES, 2002 e 2007. BUSH e FOLGER, 2005).

Dentro dessa perspectiva, o foco não é a solução dos conflitos, mas sua regulação. Ou seja, a busca de formas de se lidar com as situações conflituosas em detrimento da busca de soluções a qualquer custo. Para Six (2001) e Warat (2004) ocorre, então, um maior enfoque no processo de gestão e na busca por formas autônomas de enfrentamento.

Assim, nessa segunda perspectiva, adotada no presente trabalho, o conflito é integrante da vida e intrínseco à pluralidade e à convivência humanas. É, assim, ele próprio motor de mudança social. Aliás, nessa concepção, a existência do conflito é que denota a harmonia social. Tal concepção não é uma inovação. Na verdade, pode-se encontrá-la, por exemplo, em Lao Tzu (entre os séculos XIV e IV a.C) ou Heráclito (D a.C).

No Tao-te King (LAO-TZU, 1995) todos os fenômenos são percebidos como integrantes de seu próprio antagonismo. A harmonia da vida é conseguida quando os elementos antagônicos podem conviver, numa espécie de dialética:

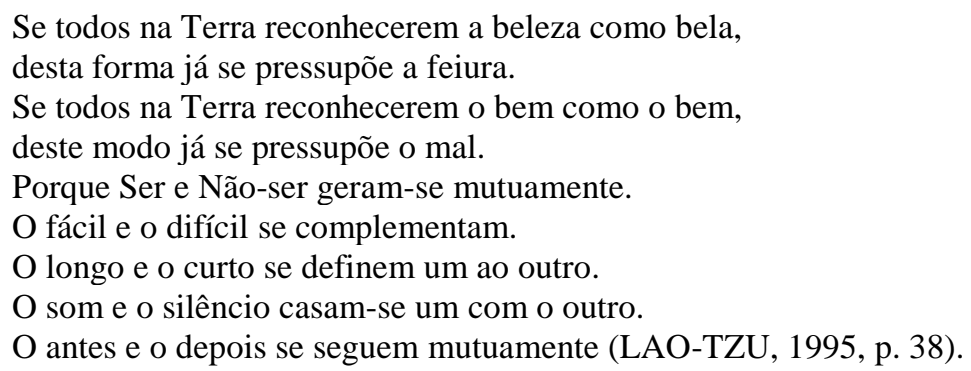

Para Wilhelm (LAO-TZU, 1995), nos comentários à obra, o mundo está em constante transformação e movimento em razão de seus próprios antagonismos. Para ilustrar esse pensamento no Ocidente, o autor remete-se a Tolstói e a sua teoria da não violência. De fato, ao narrar sua forma de lidar com as brigas de estudantes e as desordens em sala de aula de sua escola, Tolstói (s.d) fala justamente da necessidade de deixar a ordem se estabelecer por si mesma, de forma que a relação com os conflitos é assim entendida:

[...] quão arbitrários e injustos são todos os métodos educativos em comparação com este. "São ambos culpados, de joelhos" - diz o educador. Aqui, ele não tem razão porque o culpado é um e este festeja a vitória estando de joelhos e ruminando o ódio que não tinha saído; o inocente é castigado duas vezes. Ou: "Tu és culpado porque 
fizeste isto e serás castigado - diz o educador, e o castigado passa a odiar mais o seu inimigo porque do lado dele está o poder despótico, cuja legitimidade ele não reconhece. Ou: "Desculpa-o, assim ordena deus, sê melhor do que ele" diz o educador. Vós dizeis-lhe: sê melhor do que ele, mas ele apenas quer ser mais forte e não compreende nem pode compreender que haja algo melhor. Ou: "São ambos culpados, peçam desculpa um ao outro e abracem-se, meninos" Isto é ainda pior porque o abraço não é sincero e porque o mau sentimento volta a surgir com mais força. Deixai-os sozinhos, [...]; deixai-os sós e vejam como tudo se resolve simples e naturalmente e, ao mesmo tempo, de forma complicada e variada, tal como todas as relações inconscientes na vida.

Ou seja, o conflito deve encontrar sua expressão, não devendo ser sufocado. Qualquer tentativa nesse sentido só gerará mais conflito e sofrimento, mesmo na escola.

Em concordância com as ideias de Lao-Tzu encontra-se também, entre os filósofos pré-socráticos, Heráclito (SOUSA, 1999), cuja concepção é que o mundo é movimento e todas as coisas possuem dentro de si seu próprio oposto.

Como exemplo desse pensamento, pode-se citar o fragmento $n^{\circ} 8$ de Heráclito que diz "o contrário é convergente e dos divergentes nasce a mais bela harmonia, e tudo segundo a discórdia" (SOUZA, 1999, p. 88), e o fragmento $n^{\circ}$ 51: "não compreendem como o divergente consigo mesmo concorda; harmonia de tensões contrárias, como de arco e lira" (SOUZA, 1999, p. 93). Ou seja, a harmonia musical vem justamente das tensões e das diferenças dos acordes e dissonantes, de forma que a beleza tem origem na oposição entre unidade e diversidade.

Em outras palavras, a harmonia, mesmo a social, dá-se na convivência dos diferentes por meio da contestação e do conflito, de forma que todas as coisas nascem dessa discórdia e das necessidades. Ou melhor, a necessidade de cada um faz a discórdia, o combate e, com isso, gera a justiça, conforme o fragmento 80 de Heráclito: "é preciso saber que o combate é o que-é-com [comum], e justiça é discórdia, e que todas as coisas vem a ser segundo discórdia e necessidade" (SOUZA, 1999, p. 96).

A partir dessas lutas e desses conflitos estabelecem-se relações de autoridade (deuses, homens e escravos) ou de pluralidade (homens livres), tal como expresso no fragmento $\mathrm{n}^{\circ}$ 53: "o combate é todas as coisas pai, de todas rei, e uns ele revelou deuses, outros homens; de uns fez escravos, de outros livres" (SOUZA, 1999, p. 93). Mas a questão central é que isso não significa a perpetuação de um modelo: assim como tudo flui, é dinâmico, também essa situação será mudada pelo conflito, pela luta.

Há, assim, em Heráclito, uma ideia da necessidade do conflito para o desenvolvimento e para a justiça, também encontrada, quase dois mil anos depois, em Maquiavel (1994) que considera a "república perfeita" aquela fundada no conflito. Para ele, a partir da análise da república romana, a causa da grandeza romana seria a desunião entre 
plebeus e patrícios. O motivo para tanto é que o conflito existente entre esses grupos teria originado os tribunos, magistrados atuantes junto ao Senado com o objetivo de defender os interesses plebeus, dando origem a leis de liberdade:

[...] em todos os governos duas fontes de oposição: os interesses do povo e os da classe aristocrática. Todas as leis para proteger a liberdade nascem da sua desunião (MAQUIAVEL, 1994, p. 31).

Assim, é o conflito que dá origem à liberdade, principalmente quando encontra espaço para se manifestar. Ou seja, quando as partes em conflito possuem voz, quando não há leis e normas a impedir o tumulto. Para o autor, se não houvesse essa liberdade, os romanos "deixariam de ter todos os meios para desenvolver-se" (MAQUIAVEL, 1994, p. 38), pois:

[...] é útil e necessário que as leis da república concedam à massa um meio legítimo de manifestar a cólera que lhes possa inspirar um cidadão; quando este meio regular é inexistente, ela recorre a meios extraordinários: e não há dúvida de que estes últimos produzem males maiores do que os que se poderia imputar aos primeiros (MAQUIAVEL, 1994, p. 41).

Assim, o conflito não pode ser sufocado sob pena de seu reaparecimento de forma mais acirrada. Além disso, a luta pela liberdade "raramente prejudica a liberdade, porque nasce da opressão ou do temor de ser oprimido" (MAQUIAVEL, 1994, p. 32).

É nesse sentido que Deutsch (2004) considera que reconhecer o conflito tem a função de integrar e estabilizar relacionamentos e grupos sociais, pois ele constitui-se em raiz de mudança social e de formação de identidades, coletiva ou individual. Com isso, uma sociedade pode se beneficiar do conflito, pois:

Na medida em que a explosão de um conflito indica a rejeição de uma acomodação anterior entre as partes, uma vez que o respectivo poder dos contendores tenha sido averiguado no conflito, um novo equilíbrio pode ser estabelecido e o relacionamento pode prosseguir sobre essa nova base (DEUTSCH, 2004, p. 54).

Ao se compreender o conflito como um mecanismo estabilizante e institucionalizá-lo, um grupo social, comunidade ou sociedade pode assegurar sua própria continuidade sob condições adversas, o que não é possível num sistema rígido e autoritário. Conforme Deutsch (2004) tentativas de abafamento ou supressão do conflito deixam de perceber avisos úteis de crise ou de necessidade de reajustamentos, aumentando o risco de colapso do sistema.

Esse processo se dá pelo fenômeno da escalada (ENTELMAN, 2002. DEUTSCH, 2004. GALTUNG, 2003).

Escalada é o fenômeno de aumento da magnitude da conduta conflituosa que, por sua vez, cria um ciclo vicioso crescente entre as partes conflitantes (ENTELMAN, 2002). Ela ocorre porque a dinâmica de um conflito decorre da interação de todos os seus elementos, 
vistos a seguir, o que significa que sua transformação está sujeita às mudanças de atitudes, tomadas de decisões, às estratégias utilizadas ou não e às relações de poder estabelecidas.

Assim, um ato agressivo de um grupo A, por exemplo, pode fomentar a solidariedade e aumentar o compromisso dos participantes de um grupo B, submetido ao ato. O grupo B, então, passa a ter maior predisposição para absorver os custos envolvidos no uso da violência, produzindo a escalada. Nesse sentido, são aqui considerados atos agressivos as tentativas de abafar o conflito ou de impedir sua manifestação.

Mas há também a possibilidade de que a escalada ocorra em razão da "profecia auto-realizável": uma ação hostil é iniciada apenas porque há o temor de que o outro inicie uma ação semelhante (DEUTSCH, 2004).

Em qualquer caso, barrar a escalada torna-se cada vez mais difícil porque, uma vez iniciada, ações tendentes à desescalada (desescalamiento ou desplazamiento), isto é, à diminuição do nível de animosidade podem ser compreendidas como fragilidade ou fraqueza, como causadoras de perdas ou de prejuízo (ENTELMAN, 2002). De qualquer forma, autores como Deutsch (2004), Entelman (2002) e Moore (1998), da área de teoria dos conflitos e de mediação, bem como Galtung (2003) e Jares (2002 e 2007), na área dos estudos para a paz, ou ainda autores relacionados ao político, como Arendt (2005), Rancière (1996) e Lefort (1991) trazem a importância de se desenvolver ações voltadas à compreensão dos elementos e da dinâmica do conflito, a sua aceitação e regulação bem como à construção de lógicas flexíveis à conflituosidade. Sendo assim, serão apresentados primeiramente os elementos e a dinâmica do conflito.

\subsection{Elementos e Dinâmica do Conflito}

A análise dos conflitos define o campo de estudo da conflitologia, sendo diversos seus aspectos definidores. Um deles é o conceito do conflito, ao passo que outro aspecto são as concepções percebidas, ambos temas já apresentados neste trabalho. Contudo, há ainda uma teoria geral que analisa e compreende o conflito em todos os âmbitos da vida, sejam conflitos internacionais ou sociais, interpessoais ou políticos. Nesse sentido, é importante compreender como eles surgem, como se desenvolvem, quais os envolvidos e as relações que possuem entre si, bem como as estratégias e táticas mais utilizadas e suas possíveis consequências ao conflito, em geral, e a seus participantes. Daí serem apresentados a seguir os sujeitos, os aspectos objetivos e a dinâmica do conflito. 


\subsubsection{Os sujeitos do conflito}

Conflitos, principalmente os aqui considerados, sendo excluídos os conflitos psicológicos, ocorrem entre indivíduos, grupos, organizações, instituições e coletividades. Contudo, são as pessoas que devem ser consideradas, pois elas é que estarão sujeitas às decisões e às consequências advindas dessas ações. Assim, mesmo que se possa considerar uma entidade como parte de um conflito, não é possível perder de vista o ser humano que dela faz parte (ENTELMAN, 2002).

Todavia, pode ser difícil identificar partes em um conflito, pois, por exemplo, dentro de um mesmo grupo pode haver tanto objetivos idênticos, quanto incompatíveis entre os envolvidos, assim como compatibilidade com pessoas de fora desse grupo. Pode ainda haver variações quanto a formas de organização ou até mesmo de percepção da existência do conflito, entre outras possibilidades de interação, tal como indica Entelman (2002).

Além disso, as interações possíveis podem levar à fragmentação de um sujeito participante, no caso de uma entidade, organização ou coletividade, em razão de alguns de seus integrantes poderem compartilhar ideais e valores do outro grupo (ENTELMAN, 2002). Daí a importância da identificação dos sujeitos integrantes de um conflito. Mas, talvez o mais importante nessa identificação seja o fato de que o reconhecimento dos sujeitos integrantes de um conflito implica o reconhecimento de sua legitimidade à fala e à discussão (RANCIÈRE, 1996). É por isso que Entelman (2002) considera que processos de desumanização, ou seja, de não reconhecimento de sujeitos, significam a não partilha do conflito.

Assim, reconhecer os integrantes de um conflito e sua legitimidade para integrá-lo significa reconhecer uma igualdade entre os conflitantes e uma vida comum.

Isso não significa, contudo, reconhecer igualdade de condições entre as partes, pois tais situações dependem da organização de cada lado, de aspectos culturais, das relações de poder existentes, do nível de envolvimento de cada um (ENTELMAN, 2002, RANCIÈRE, 1996). Também não significa que se considerem legítimas as ações ou decisões eventualmente tomadas, conforma lembra Deutsch (2004) quando fala que pessoas em conflito consideram suas próprias pretensões mais legítimas e bem-intencionadas que as demais. Mas é a partir dessa identificação que o próprio conflito pode ser reconhecido.

Mesmo entre as partes de um conflito, o tipo de envolvimento pode variar, podendo haver partes principais, secundárias ou terciárias (PASQUINO, 1995). Isso rompe com a ideia de que um conflito vai ser sempre polarizado e as partes serão sempre antagônicas entre si. Ao contrário, a multiplicidade de atores e de níveis de envolvimento cria o que Entelman (2002) chama de "magnetismo conflitual” que forma vários níveis de interação. 
Para melhor compreensão dessas questões tratar-se-á, a seguir, sobre os aspectos objetivos do conflito.

\subsubsection{Aspectos objetivos do conflito}

É possível pensar a análise objetiva do conflito como fez Pasquino (1995), ou seja, considerando a dimensão, a intensidade e os objetivos do conflito.

A dimensão relaciona-se ao número de participantes envolvidos, quer seja um número absoluto, quer seja relativo à representação de potenciais participantes, o que tem a ver com a própria identificação dos sujeitos do conflito. É o que apresenta Riskin (2002) quando relaciona o âmbito de um conflito aos problemas principais e acessórios que variam desde um nível bem restrito (apenas aspectos focais e bem delimitados) até o mais amplo.

Nesse sentido, analisar o âmbito do conflito pode significar analisar apenas aspectos pontuais (nível I) ou ainda aspectos emocionais mais profundos até uma dimensão mais ampla, que envolve interesses comunitários ou de instituições que, mesmo não sendo partes imediatas, podem ser aperfeiçoadas ou transformadas a partir do tratamento dado a um conflito (nível IV). Pode-se compreender essa ideia a partir do diagrama abaixo:

Gráfico 1 - Eixo de definição do problema

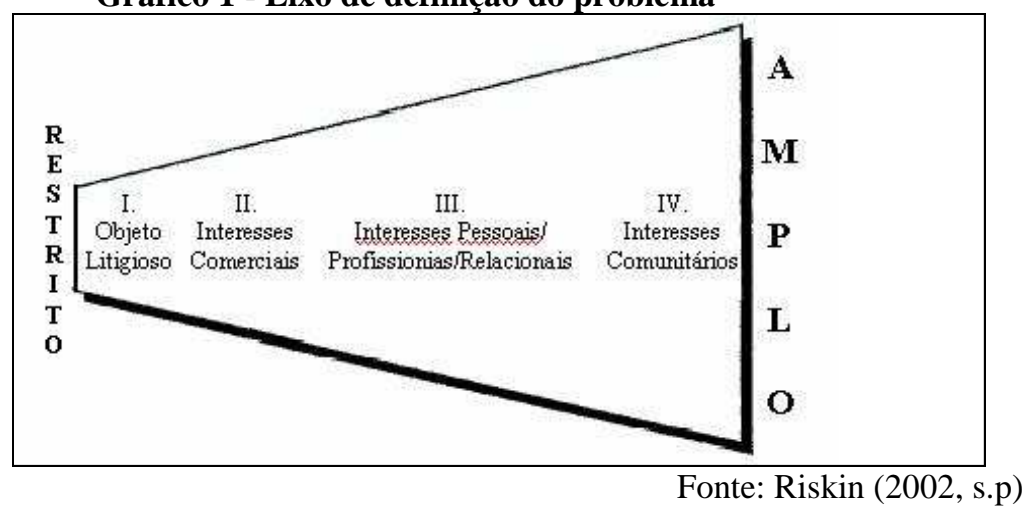

O gráfico de Riskin (2002) foi criado para a análise de casos submetidos à mediação e não a uma teoria geral do conflito, tendo recebido críticas ao relacionar a mediação a uma avaliação e permitir uma analise muito restrita do conflito. Contudo, ele foi aqui apresentado porque, por meio dele, é possível perceber que os conflitos podem ser analisados desde um âmbito pontual e restrito até a maior complexidade possível, envolvendo uma comunidade.

Nesse sentido, por exemplo, num conflito escolar, um aluno ou aluna A pode estender a perna e, com isso, um aluno ou aluna B tropeçar na escola e machucar-se. A análise desse conflito pode ser apenas pontual (foi um caso isolado e A e B não possuem uma relação próxima), como também envolver aspectos relacionais (há algum fato específico na relação 
entre A e B que motivou a ação de A e (ou) impactou B), ou ainda institucional ou comunitário (esses são casos comuns e corriqueiros numa escola que, por sua vez, não sabe ou não quer lidar com a situação). Identificar e diferenciar esses aspectos do conflito permite a escolha de métodos eficazes de sua administração.

É dentro dessa proposta que Santos (1988) fala de relações de vínculo único (uniplexas) e relações de vínculo múltiplo (multiplexas). Aquelas são as relações passageiras, cujos vínculos são estabelecidos com estranhos (SANTOS, 1988), ao passo que essas são as relações contínuas, "em que as pessoas estão ligadas entre si ou com a comunidade circundante por interesses ou valores" (COSTA, 2003). Nesse sentido, o que está em causa é o distanciamento dos participantes do conflito, que influi na própria forma de se lidar com ele, diante de um agir mais ou menos comprometido, positiva ou negativamente, nas relações multiplexas (COSTA, 2003). Nas palavras de Santos (1988, p. 23):

No caso da distinção relações multiplexas/uniplexas o que está em causa é a configuração da distanciação social entre os participantes no litígio e a sua relevância para o processamento deste [...].

É hoje comunmente (sic) reconhecido que as relações multiplexas, quando intensas, comandam todo o contexto da decisão do litígio e de tal modo que o objecto (sic) ostensivo deste representa por vezes a expressão mínima de uma relação antagonística de longa duração entre duas famílias ou grupos [...].

Já a intensidade do conflito relaciona-se ao grau de envolvimento e à de disposição de seus participantes para enfrentar a situação, sua disponibilidade em resistir, perseguindo os chamados fins não negociáveis, isto é, seus reais objetivos (PASQUINO, 1995. ENTELMAN, 2002). Assim, a intensidade de um conflito vai envolver a possibilidade de sua permanência ao longo do tempo. Quanto mais intenso, mais envolvidas as pessoas e mais dispostas a continuar em busca de seus objetivos. Isso não significa, por seu turno, uma relação direta com a escalada, pois é possível que a intensidade do conflito seja alta, com as partes sem interesse de abandoná-lo, mas sua ações desenvolvidas dentro de aspectos cooperativos.

Quanto aos objetivos de um conflito, ou seja, ao que se pretende alcançar com o conflito, os interesses e valores que devem ser atendidos, há, conforme Entelman (2002) três tipos: concretos, simbólicos e transcendentais.

Enquanto os objetivos concretos são apenas posições, como um pedido de separação, a saída de sala de um aluno, uma punição específica, sendo tangíveis, divisíveis e perceptíveis, os demais são mais sutis e complexos, pois se relacionam às emoções e sentimentos. Já os objetivos transcendentes são os valores em si mesmo, como a honra, a 
justiça, o reconhecimento, não tangíveis nem divisíveis, mas que estão envolvidos numa disputa (ENTELMAN, 2002; AZEVEDO, A.G, 2003; PASQUINO, 1995).

A importância de se descobrir os reais objetivos de um conflito reside na possibilidade de satisfazê-los e, com isso, transformar efetivamente a situação conflituosa. Isso, no entanto, não raras vezes, é um dos principais desafios na compreensão de um conflito, pois é possível que partes possam se recusar a reconhecer determinado assunto como seus objetivos reais (ENTELMAN, 2002).

Por outro lado, é possível que sejam claros, mas que se relacionem justamente ao que Castoriadis (1982) chama de projeto revolucionário. Ou seja, o objetivo é justamente a transformação social dificultada por aqueles que defendem a manutenção do status quo.

Diante disso, duas são as possibilidades. De um lado, ao descobri-los e buscar seu atendimento, torna-se possível evitar a chamada "litigiosidade remanescente", ou seja, a permanência das causas de um conflito mesmo diante de um acordo ou solução (AZEVEDO, A.G. 2004). De outro, é possível que o conflito seja regulado, ainda que seus objetivos não o sejam facilmente atendidos, e assim se evite a escalada de violência (ENTELMAN, 2002. GALTUNG, 2003. DEUTSCH, 2004).

Assim, descobrir os reais objetivos de um conflito e atendê-los significa dar fim à litigiosidade ou conflituosidade remanescente, o que pode ser compreendido com a resolução de um conflito. Isso, no entanto, não significa a extinção do conflito em si, em especial no caso de relações permanentes ou de vínculo múltiplo, mas apenas a transformação da relação (PASQUINO, 1995. SANTOS, 1988. COSTA, 2003. BUSH e FOLGER, 2005).

Por outro lado, conflituosidade remanescente pode dar origem ao que foi apresentado como escalada, ou seja, o movimento de aumento de intensidade não do conflito em si, mas das ações de seus participantes, o que pode dar ensejo à violência. Diante disso é que surge a necessidade do reconhecimento do conflito e do estabelecimento de sistemas flexíveis, que o conflito e que, portanto, podem ser mais coesos e fortes. É então que se encontra a relação entre conflito e democracia.

\subsection{Conflito e Democracia}

O conflito possui como locus de existência o político, isto é, as formas de instituição e ordenação da sociedade e não apenas os processos de alternância de poder. Nesse sentido, a democracia não é apenas um regime político, mas, acima de tudo, uma forma de organização social contrária à tirania (LEFORT, 1963 e 1991. RANCÈRE, 1996 e 2005. ARENDT, 2004, 2005 e 2013). 
Nesse sentido, o político é a própria relação entre os seres humanos e suas visões de mundo. É a coexistência social que se dá nos princípios que geram e fundamentam uma sociedade, estando, portanto, presente em todos os seus corpos e instituições sociais (LEFORT, 1991), entre elas a escola. Assim, a escola integra o político.

Para Rancière (2005), o político são os princípios pelos quais uma comunidade é delimitada e caracterizada. É, então, uma "partilha do sensível”, ou seja, a forma como cada um participa no fato de "governar e ser governado", que é única para cada pessoa, marcada permanentemente por uma disputa quanto ao seu posicionamento nessa realidade.

Para Arendt (2005, p. 34), a política se relaciona à esfera pública, ao viver em comum e à pluralidade, pois "somente a ação humana, a política, é a ação que depende inteiramente da presença de outros. Somente a ação (praxis) e o discurso podem ser considerados políticas". É nessa ação que se encontra a condição humanai. Contudo, a autora separa a vida privada e a pública (política), colocando a educação dentro da vida privada e, portanto, fora do político. Essa ideia vai de encontro ao pensamento de Lefort e Rancière e à ideia central deste trabalho, que considera a educação e a escolarização ações políticas.

Assim, a importância da democracia é se colocar como uma forma de sociedade fundada na legitimidade do conflito. Só há, portanto, democracia, quando há a partilha de uma vida comum e o enfrentamento às contradições advindas da heterogeneidade das vontades coletivas (LEFORT, 1991).

Nesse sentido, é preciso lembrar que, assim como defende Rancière (1996 e 2005), o conflito nunca é apenas sobre o objeto em si, mas também sobre o direito de se nomear esse objeto, de participar do espaço em comum, ou seja, o conflito primário é composto pelo desentendimento: a luta ao direito de ter a voz de manifestar o conflito, isto é, de constituir a democracia.

É por isso que, ao se falar de democracia, não se está a falar da chamada democracia liberal, na qual a pluralidade é constantemente pacificada na busca de um consenso. Tal democracia é o que Rancière (1996) chama de polícia, uma falsa democracia.

Isso porque polícia são as instituições de controle com o objetivo de forjar uma harmonia e uma pacificação da vida em comunidade de forma que, mesmo num regime chamado de democrático, não haveria espaço para a contradição (RANCIÈRE, 1996 e 2005). Nisso, certos grupos são permanentemente silenciados, enquanto a outros é dada a primazia de participar do espaço público e ter papel ativo na partilha do sensível. Há, assim, uma pacificação e uma harmonia que não se revestem de vida comum e, portanto, não podem ser consideradas democracia. 
Diante disso, surge a necessidade de uma permanente luta pelo reconhecimento e acolhimento ao conflito e às contradições, essência da democracia, um espaço comum de convivência no qual não há uma delimitação permanente sobre aqueles que detêm o monopólio da palavra ou da ação (RANCIÈRE, 1996).

Assim, a democracia é um processo de tornar visíveis os que estão invisíveis, alargando in continuum a esfera pública que se estende a todas as instituições, entre elas a escola. Nesse sentido, o caminho do político na escola perpassa por sua democratização e o processo de tornar a instituição um espaço de vida comum, que recebe e aceita o conflito. A questão que então se coloca é como essa lógica torna-se possível na escola.

\subsection{Transformação dos conflitos na escola}

Lidar com os conflitos no âmbito escolar significa compreender as causas e os elementos das situações que permeiam o contexto institucional, a fim de melhorar o próprio processo de ensino-aprendizagem.

Contudo, diante da realidade apresentada no capítulo 1, sobre a escola, expressa nos fundamentos da escola e na crise expressa em seus paradoxos na atualidade, lidar com tal situação significa transformar o modelo de escola vigente.

Nesse sentido, é que encontramos em Ortega e Del Rey (2002) três parâmetros que devem ser considerados nessa transformação: gestão democrática, trabalho cooperativo e educação para os sentimentos, atitudes e valores. Conforme visto no capítulo anterior, essa estrutura é semelhante à apresentada por Debarbieux (2006) como uma das formas efetivas para se lidar com a violência no contexto escolar.

Jares (2002 e 2007), por sua vez, em consonância com os aspectos de educação para a paz, vai considerar a necessidade da democratização das estruturas escolares, o que inclui os processos decisórios, a metodologia de ensino e a convivência escolar. Contudo, Singer (2010) considera um processo mais amplo: a eliminação de qualquer relação de mando e obediência existente na escola e a adoção de procedimentos que permitam a plena autonomia ao educando. É o que Illich (1985) vai considerar a desescolarização da sociedade.

Considerando, como Gentili (2009), que a sociedade atual não parece disposta a abdicar da instituição escolar, cabe refletir, então, sobre formas que permitam a transformação a partir da aceitação do conflito. Diante disso, e a partir dos autores acima mencionados, bem como tendo em mente o escopo desde trabalho, a educação para os direitos (EDH) mostra-se uma das propostas para essa transformação. 


\subsubsection{Educação para os direitos humanos (EDH)}

Ao se falar de educação para os direitos humanos (EDH), dois conceitos aparecem: educação e direitos humanos. Sobre o primeiro, tratou-se no primeiro capítulo deste trabalho, restando, com isso, trabalhar o segundo na presente seção.

A expressão "direitos humanos" relaciona-se a um locus específico: uma construção de lutas a partir de valores ocidentais que culminaram na instituição de normas de direito internacional (GALTUNG, 1998).

O problema nessa conceituação advém de se considerar direitos humanos como universais, uma das principais características colocadas por seus defensores. Isso porque conceber direitos humanos nascidos de valores e lutas ocidentais como direitos humanos universais seria o mesmo que aceitar a história ocidental como história universal ou a cultura ocidental como cultura universal (GALTUNG, 1990). Diante da hegemonia ocidental sobre os demais povos, presente nas formas de imperialismo, inclusive o moral, tal universalidade pode legitimar a violência cultural, conforme expresso por Galtung (1990 e 1998) e Hernàndez-Truyol e Gleason (2002).

Além disso, Jelin (2007, p. 161) menciona que a Declaração Universal de Direitos Humanos traz uma noção de que os direitos humanos seriam "individualistas e ocidentais, e que o desejo de estendê-los ao mundo todo era um ato de poder imperialista, discriminatório e etnocêntrico". Sendo assim, tal visão também poderia:

[...] justificar as violações de direitos, sob a proteção do relativismo cultural e com uma insistência na soberania nacional e na autodeterminação, tudo o que poderia levar a uma rejeição das intervenções humanitárias e do monitoramento e controles internacionais (JELIN, 2007, p. 161).

Diante disso é que os direitos humanos devem ser dissociados da normatividade advinda das declarações, dos tratados e das convenções e relacionado aos processos de luta social, tal como defendido por Herrera Flores (2009), existentes em qualquer grupo ou comunidade humana (SEGATO, 2006). Eles saem, assim, de seu aspecto exclusivamente ocidental.

Ao serem processos de luta "por algo" denotam uma realidade considerada injusta por grupos marginalizados que compreendem como dever ético ir além e mudar um costume ou uma tradição (HERRERA FLORES, 2009.; SEGATO, 2006. HERNANDEZTRUYOL; GLEASON, 2002). Por outro lado, manifestam um ideal a ser conquistado, uma luta por um projeto político de sociedade.

Daí direitos humanos serem compreendidos como um paradigma ou anseio ético (SEGATO, 2006) que deve ter como base os conflitos e as lutas sociais, relacionados às 
mais diversas práticas culturais, responsáveis por permitir a revelação dos recursos internos de cada grupo ou comunidade e as soluções pacíficas diante dos conflitos (HERNANDÈSTRUYOL, GLEASON, 2002). Nesse sentido, eles são o paradigma e o próprio processo da transformação dos conflitos diante da necessidade de atendimento a necessidades humanas.

Contudo, nesse ponto, Candau (2005) e Sacavino (2009) ao discorrerem sobre o desenvolvimento da educação para os direitos humanos (EDH) na América Latina apresentam as dificuldades de sua conceituação diante dos aspectos nela envolvidos: ideologias e pedagogias, concepções de direitos humanos e ainda com relação aos sujeitos relacionados (governos, ONGs ou educadores e acadêmicos). Nesse último caso, cada um deles teria um conceito, tanto de educação, quanto de direitos ou de direitos humanos.

Até mesmo a conceituação de educação em ou para os direitos humanos parece não haver uma unanimidade, a ponto de Sacavino $(2009$, p. 65) referir-se à "educação em/para os direitos humanos".

E é justamente diante desse debate que houve a opção, neste trabalho, conforme explicado na introdução, pela ideia de educação para os direitos humanos. Isso porque, considera-se que o que deve ser levado em conta é que toda a prática pedagógica e toda a estrutura escolar devem estar voltadas para a busca de uma vivência numa cultura de direitos humanos, o que exige um:

[...] compromisso ético, social e político capaz de se traduzir em práticas alternativas e transformadoras que se consolidem tanto em normas exteriores e institucionais quanto em convencimento e vivência (CARBONARI, 2007, p. 184).

Assim, todo o processo educativo deve "conscientizar acerca da realidade, identificar as causas dos problemas, procurar modificar atitudes e valores, e trabalhar para mudar situações de conflito e de violações dos direitos humanos" (BRASIL, 2013, p. 15). Ou seja, os processos escolares devem ser pautados na dignidade humana, na justiça e na tomada de decisões éticas. Devem ainda questionar crenças e tradições relacionadas a formas de opressão autoritária, como o racismo, o sexismo, a superioridade cultural, a pobreza e a injustiça social (REARDON, 2007). Petr (1992) e Vasquez (2013) vão lembrar ainda do adultocentrismo, isto é, das práticas de exclusão baseadas nas diferenças geracionais (VASQUES, 2013) ou a percepção dos problemas das crianças e adolescentes exclusivamente sobre o ponto de vista ou perspectiva do adulto (PETR, 1992).

Com relação aos conflitos, isso significa a busca da compreensão de suas causas a fim de se "esclarecer os valores de justiça e igualdade e a aplicação de princípios de justiça" (REARDON, 2007, p. 66) em oposição a simples tentativas de "resolução". 
Em relação ao adultocentrismo, não significa o rompimento da autoridade existente entre adulto e criança e adolescente ou, no contexto escolar, entre profissionais e alunos. Mas a instituição de processos decisórios, de normas ou de formas de resolução de conflito não baseadas exclusivamente na conveniência ou na ideia de supremacia dos adultos. A proposta é que sejam considerados os pontos de vista dos estudantes e as decisões tomadas busquem sempre o seu melhor interesse, num processo de promoção de autonomia e liberdade dos estudantes permeada pela autoridade democrática, no dizer de Freire (1996).

Nesses termos, uma educação pautada exclusivamente no aspecto punitivo (com ameaças, constrangimentos e retirada do amor) e autocrático (resolução vinculativa por um terceiro) mostra-se contrária a uma educação para os direitos humanos.

Aliás, Assis e Vinha (2003), em pesquisa sobre o impacto das formas escolares (autocrática ou democrática) de resolução de conflitos em duas turmas de alunos da terceira série do ensino fundamental, demonstraram que a punição só funciona quando a criança tem medo do adulto e, mesmo assim, resolvem apenas temporariamente, pois não trabalham as causas nem possuem ação direcionada ao futuro. Além disso, quando não há medo, punições são inócuas no sentido educativo e, pior, podem causar raiva provocam sensação de injustiça.

Em outros termos, a EDH tenciona formar sujeitos de direito, favorecer processos de empoderamento e educar para o "nunca mais" (CANDAU, 2005, p. 405).

Sujeito de direitos na dogmática jurídica é qualquer pessoa que possui direitos e obrigações prescritas dentro do ordenamento jurídico. Contudo, Santos (2006), a partir de uma crítica ao direito e aos direitos humanos, considera que, para ser sujeito de direitos é necessário envolver-se nos processos e lutas históricas, caso contrário se está diante de um objeto de direitos. Sujeito de direitos é, assim, aquele que se coloca no mundo, que possui consciência de seus direitos (CARBONARI, 2007. CANDAU). Para Jelin (2007) sujeito de direitos é também aquele que possui solidariedade ou a responsabilidade "retrospectiva", isto é, um agir guiado pela consciência pessoal, pela sensação do justo e do ético.

$\mathrm{O}$ segundo elemento de uma EDH relaciona-se aos processos de empoderamento de grupos historicamente oprimidos "favorecendo sua organização e participação ativa na sociedade civil" (CANDAU, 2005, p. 405). Em outras palavras, diante de situações de conflito ou violência, deve-se favorecer a organização e a luta por direitos de tais grupos bem como se deve auxiliá-los na busca por espaços de discussão. No contexto escolar, conforme Reardon (2007) seu objetivo deve ser o de permitir a convivência e a existência plural, principalmente diante do conflito 
Por fim, o último eixo da EDH refere-se ao educar para o "nunca mais". A ideia presente é que violações de direitos humanos não devem ser esquecidas. Ao contrário, deve-se "resgatar a memória histórica, romper a cultura do silêncio e da impunidade" ainda presente na atualidade (CANDAU, 2005, p. 405). Sob tal perspectiva, a EDH deve direcionarse à divulgação de fatos históricos que implicaram violações de direitos humanos, transmitindo às novas gerações valores que permitam a conscientização.

Tal eixo não se relaciona apenas aos grandes fatos históricos, mas também às violências e incivilidades no contexto escolar. Sua expressão se dá no reconhecimento da existência desses fatos, na tentativa de rompimento com a cultura do silêncio e da impunidade dentro da instituição e no estabelecimento de processos que permitam a conscientização dos envolvidos acerca da gravidade dos acontecimentos. A educação para o "nunca mais" deve ser, assim, voltada a novas formas de relacionamento e de compreensão do outro.

Desenvolver uma educação contrária à impunidade, não significa, porém, a ênfase no aspecto punitivo, sob o risco de se incidir em escalada. Nem mesmo a completa ausência de sanções. Mas a busca de conscientizações e de formas de compensação, expressas em campanhas de prevenção e em ações pautadas na busca do diálogo.

Nesse sentido, a EDH implica a criação de processos e de procedimentos, de locus de atuação que permitam o acolhimento, o respeito e a dignidade do outro, bem como a intransigência com processos, posturas ou construções que, mesmo sob o argumento de “culturais", favoreçam a naturalização da violência (REARDON, 2007).

Entre tais processos, procedimentos ou locus de atuação, pode se encontrar a mediação de conflitos. Ela deve permitir, assim, a formação de sujeitos de direito, buscar o fortalecimento dos grupos oprimidos e permitir a conscientização para o "nunca mais" a partir de um processo que seja condizendo com seu fim, ou seja, no qual o processo seja ele mesmo baseado na dignidade humana.

Essas questões serão melhores compreendias a partir do próximo capítulo, que tratará sobre a mediação de conflitos. 


\section{MEDIAÇÃO DE CONFLITOS}

A palavra mediar vem do latim, mediare, que significa mear, ficar no meio de, estar no meio, dividir ao meio. Ou seja, qualquer relação de intermediação traduz-se em mediação. Daí poder-se compreender que um corretor de imóveis é um mediador entre comprador e vendedor, o professor é o mediador entre o estudante e a aprendizagem, o padre é um mediador entre Deus e seus crentes. Para Muszkat (2005, p. 12), qualquer "mãe de família ou profissional que trabalhe com pessoas - como um professor ou advogado - dirá, com segurança, que medeia desde sempre".

Não são essas as concepções adotadas no presente trabalho. A mediação, aqui, tem sua relação direta com o conflito e com uma práxis específica e estruturada, sendo um processo no qual um terceiro colabora com as partes diante de uma situação conflituosa. Por isso os termos mediação e mediação de conflitos são aqui indistintamente aplicados, ou seja, significam a mesma coisa.

Muszkat define mediação como episteme (saber resultante de outros saberes que fornece instrumental para uma prática) na qual um o mediador busca:

[...] acordos entre pessoas em litígio por meio da transformação da dinâmica adversarial, comum, no tratamento de conflitos, para uma dinâmica cooperativa, improvável nesse contexto (MUSZKAT, 2005, p. 13, grifo no original).

Sales (2003 e 2007) a conceitua como um procedimento pacífico por meio do qual um terceiro de fora do conflito age para encorajar e facilitar a resolução de um conflito. Já para Bush e Folger (2005, p. 135) é um "processo informal no qual um terceiro neutro sem poder de impor uma resolução ajuda partes em disputa a tentar alcançar uma solução mutualmente aceitável"1. Warat (2004, p. 75), por fim, compreende-a como "procedimento indisciplinado de auto-ecocomposição assistida (ou terceirizada) dos vínculos conflitivos com o outro em suas diversas modalidades".

Diante desses conceitos, é possível considerar a mediação um processo, que pode ser mais ou menos estruturado, mas sempre voluntário, no qual um mediador, um terceiro sem poder de decisão e sem interesse direto na causa em questão, auxilia partes em conflito a decidirem elas próprias sobre uma solução mutualmente satisfatória.

Nesse sentido, a mediação não é algo novo, mas uma prática social tradicional que se tornou uma praxis e um saber profissional. Para compreender isso, é necessário observar alguns aspectos históricos.

\footnotetext{
${ }^{1}$ No original: [...] an informal process in which a neutral third party with no power in impose a resolution helps the disputing parties try to reach a mutually acceptably settlement. (Id. Ib. Loc. cit. itálico da autora).
} 


\subsection{Mais uma história da mediação}

Não é possível encontrar uma origem definitiva da mediação de conflitos. Como prática social, formas originárias podem ser encontradas em vários povos ao longo do tempo. Cohén (1966) e Lubman (1967) mencionam sua origem na sociedade chinesa. Ginsberg (1978), Brown (1982) e Moore (1998) incluem judeus, muçulmanos, hindus, budistas, os primeiros cristãos e os japoneses como povos com processos de mediação. Além disso, Riquelme (2010) considera como mediadores povos africanos com costume de realizar assembleias. Clastres (2004), por sua vez, ao estudar os índios Guayaki do Paraguai e discutir sobre o poder dos chefes das sociedades sem Estado, apresenta o chefe indígena como alguém que não decide, mas busca uma conciliação em nome da coesão do grupo, o que o caracteriza como um mediador tradicional:

[...] o chefe não formula ordens, às quais sabe de antemão que ninguém obedeceria, mas também é incapaz (isto é, não detém tal poder) de arbitrar quando se apresenta, por exemplo, um conflito entre dois indivíduos ou duas famílias. Ele tentará, não resolver o litígio em nome de uma lei ausente da qual seria o órgão, mas apaziguá-lo apelando ao bom senso, aos bons sentimentos das partes opostas, referindo-se a todo instante à tradição de bom entendimento legada, desde sempre, pelos antepassados. (CLASTRES, 2004, p. 103 - 104).

Moore (1998, p. 33) já no “ocidente secular”, identifica a mediação nas guildas ou corporações de ofício da Idade Média. Riquelme (2010) e Péres (2006), por sua vez, mencionam o Tribunal das Águas de Valência como uma instituição que desenvolve tal prática desde sua criação, em 1239, sendo interessante citar que Peres (2006) menciona indícios da existência desse tribunal desde o ano 900.

Apesar de o Tribunal das Águas de Valência se inserir no sistema de justiça valenciano (Espanha) e ser formado por árbitros (síndicos), escolhidos democraticamente pelo próprio grupo a ele submetido e cuja decisão tem caráter obrigatório, o processo é permeado pela busca de uma solução consensual, negociada (RIQUELME, 2010. PERES, 2006. TRIBUNAL DE LAS AGUAS DE LA VEGA DE VALENCIA, 2014).

Na França, Six (2001) menciona a mediação de conflitos realizada pelo rei Luiz IX (1226 - 1270), após a missa aos domingos, quando se sentava aos pés de uma árvore e ouvia os que possuíam questões a resolver. Tal costume teria dado origem a uma norma de 1671 que atribuía aos nobres e ao clero o papel de realizar, em nome da Coroa, mediação em todos os conflitos comunitários (BARBOSA, 2007. SIX, 2001). Para Six, o cargo de "mediador da República", instituído em 1973, seria herdeiro dessa tradição. 
Mediação de conflitos também pode ser encontrada na experiência dos peregrinos norte-americanos, quakers e puritanos, a partir do século XVI. Na época, ela se estabeleceu como uma das formas de administração de conflitos sem a participação da coroa inglesa, sendo os mediadores os mais velhos da comunidade (MOORE, 1998. SIX, 2001).

A experiência da democracia direta e da prática de administração de conflitos sem acesso ao poder da Coroa, conforme Tocqueville (2004), resultou, entre os norteamericanos, no costume de administrar os conflitos, mesmo os sociais, em assembleias dos cidadãos, ou seja, processos mediados. Em decorrência disso, a partir do final do século XIX e início do século XX começam a surgir mais fortemente associações de mediação, para dirimir conflitos, especialmente trabalhistas, mas também comunitários (MOORE, 1998).

Conforme Moore (1998, p. 34), já em 1947 foi instituído o Federal Mediation and Conciliation Service nos Estados Unidos, uma agência independente para tratar da mediação no setor industrial a fim de se alcançar uma "paz industrial profunda e estável".

Também Cohén (1966) menciona que em 1964 a então União Soviética já possuía alguns anos de experiência em mediação judicial e extrajudicial ${ }^{2}$. O autor, no entanto, ao fazer uma análise do sistema chinês considera que, apesar de a China receber influências da então União Soviética, a mediação seria uma característica chinesa. Isso porque o modelo soviético não possuía os comitês de mediação popular ou comunitária (a primeira porta de acesso à justiça) já disponíveis no modelo chinês.

A partir da década de 1960 parece haver um consenso entre alguns autores de que, a partir da década de 1960, a mediação de conflitos teria sido estruturada e difundida com base na concepção chinesa, pela Universidade de Harvard, nos Estados Unidos. Nesse sentido, ela integrou o movimento pela propagação dos métodos alternativos de resolução de disputas $(A D R)$, na qual a mediação seria uma alternativa ao processo judicial (MUSZKAT, 2005. SIX, 2001. BARBOSA, 2007). Desde então o mediador de conflitos se diferencia do mediador tradicional, existente até então, e a mediação passa a se constituir um conhecimento técnico especializado.

Dentro desse modelo, surgiram, nos Estados Unidos, tanto experiências de mediadores profissionais, independentes, como os Neighborhood Justice Centers, isto é, centros de mediação comunitária com o objetivo de promover acordos, realizar conciliações e prevenir conflitos judiciais, principalmente os relacionados a processos entre vizinhos,

\footnotetext{
${ }^{2}$ No original: "During the past few years, as part of a broad effort to resolve civil disputes by means of a variety of innovations, Soviet authorities have encouraged increased use of both extrajudicial and judicial mediation" (COHÉN, 1966, p. 1203 - itálico da autora).
} 
familiares e conhecidos. O objetivo era então o apaziguamento em nome da pacificação social (McGILLIS, 1997. BRADLEY; SMITH, 2000).

Mais tarde, já na década de 1970, em decorrência do ativismo político e social da época, surgiram os Community Mediation Centers que mudaram sua atuação e sua filosofia em relação às primeiras experiências. Nesse período, a mediação comunitária surgiu como forma de fortalecimento das comunidades e grupos sociais na luta por direitos civis e na participação democrática (BRADLEY; SMITH, 2000).

McGillis (1997) considera que esses centros não se dissociam de seus objetivos iniciais, mas atuam dentro de uma filosofia diferente: seu objetivo prioritário passa a ser o de fortalecer a atuação de organizações religiosas, civis, escolares, além dos serviços sociais locais, promovendo autonomia desses grupos na gestão de seus conflitos.

Bush e Folger (2005) mencionam a atuação dos Community Boards Centers como forma de organização da comunidade ao redor de interesses comuns. Assim, conflitos inicialmente interpessoais passaram a ser compreendidos por uma ótica social de forma que a mediação acabava por promover maior participação das pessoas e dos grupos interessados na vida civil. Com isso, ela passa a ser utilizada como um meio de reduzir a distância entre os cidadãos, as agências estatais e os serviços públicos.

Tanto a mediação centrada no apaziguamento como no fortalecimento social foram difundidas por países como Canadá, Grã Bretanha, França e Argentina, entre as décadas de 1970 e 1980 (SIX, 2001 e 2005. BARBOSA, 2007. HEREDIA, 2009). Mas, ao ingressar em sociedades com experiências anteriores de mediação tradicional, tal mediação passa a ter a influência dessas práticas locais a ponto de Riquelme (2010) concluir que não há uma mediação, mas tantas quantos são os países que a adotaram.

Na França, por exemplo, a institucionalização da mediação dá-se com a criação do cargo de Mediador da República, em 1973. Surge então a mediação institucional exercida por um funcionário com a fim de evitar dificuldades entre usuários e serviços públicos (saúde, transporte, educação) e lidar com os conflitos da cidade (SIX, 2001 e 2005).

No entanto, vigora então a realidade das zonas urbanas sensíveis (zones urbaines sensibles $-Z U S$ ) dos subúrbios franceses, povoados principalmente por migrantes e seus descendentes, que vivenciam uma crescente degradação econômica e social, principalmente após a década de 70 (KOWARICK, 2003. WENDEL, 2008). O ambiente encontrado, então, é justamente os dos conflitos interculturais, relacionados à imigração e aos choques de valores, acirrados pela questão econômica, pela degradação dos espaços públicos e pela violência e criminalidade (OLIVEIRA; GALEGO, 2005). 
Como consequência, as ações de instâncias públicas de mediação, da Delegação Interministerial para a Cidade (Délégacion INterministérielle à la Ville - DIV), do Ministério da Cidade, na França, mostraram-se infrutíferas. Daí a instituição dos primeiros projetos de mediação social na década de 1980, no quais jovens passaram a atuar como "agentes intermediários" com as funções de:

- Acolher, escutar e exercer qualquer atividade que contribua à inter-relação social;

- Informar e acompanhar os cidadãos em suas gestões, facilitar o diálogo entre serviços públicos e usuários e, em especial, estabelecer laços entre os pais e os serviços que acolhem a seus filhos;

- Contribuir para melhorar ou preservar o marco vital;

- Prevenir e ajudar a resolver os pequenos conflitos da vida cotidiana através da mediação e do diálogo;

- Facilitar o diálogo entre gerações, acompanhar e reforçar a função parental mediante o apoio às iniciativas adotadas pelos pais ou em seu favor;

- Contribuir para reforçar a vida associativa local e desenvolver a capacidade de iniciativa e elaboração de projetos no bairro e na cidade (SIX, 2005, p. 43) ${ }^{3}$.

Com isso, a mediação passou por um processo de difusão que leva o termo a ser utilizado em qualquer ação social, daí acontecer um processo de sistematização, que culmina na classificação da mediação em institucional e cidadã (SIX, 2001), sendo a primeira realizada por funcionários públicos ou privados com objetivo de resolver os problemas de seus usuários, clientes ou consumidores, mantendo ou restaurando a harmonia entre esses e as instituições a que são vinculados. Já a segunda é realizada por cidadãos, líderes comunitários, cuja autoridade é concedida por seus próprios pares.

Nessa ocasião, nos Estados Unidos a atuação da mediação, seus objetivos e sua prática passa a ser questionada. É nesse ambiente que, em 1994, surge a primeira edição de Bush e Folger (2005), questionando a mediação focada na resolução de problemas (modelo inicialmente propagado por Harvard) e enfocando a mediação transformadora, isto é, uma proposta que busca a transformação das pessoas e dos conflitos.

Os debates a esse respeito podem ser encontrados nas discussões entre Riskin (2002), inicialmente publicado em 1996, e Kovack e Love (2004), publicado em 1998.

Riskin (2002) considera que entre as atribuições do mediador está a de avaliar, ou seja, informar às partes quem possui a melhor estratégia, o melhor direito, numa situação

\footnotetext{
3 No original: “* acoger, escuchar y ejercer cualquier actividad que contribuya a la interrelación social; * informar y acompañar a los ciudadanos en sus gestiones, facilitar el diálogo entre servicios públicos y usuários y, en especial, establecer lazos entre los padres y los servicios que acogen a sus hijos; * contribuir a mejorar o preservar el marco vital; * prevenir y ayudar a resolver a los pequeños conflictos de la vida cotidiana a través de la mediación y el diálogo; * facilitar el diálogo entre las generaciones, acompañar y reforzar la función parental mediante el apoyo a las iniciativas adoptadas por los padres o en su favor; * contribuir a reforzar la vida asociativa local y desarrollar la capacidad de iniciativa y elaboración de proyectos en el barrio y en la ciudad" (Id. Ib. Loc. cit. itálico da autora)
} 
de conflito, a fim de alcançar um acordo. O argumento do autor é que, na prática, essas seriam ações comuns entre mediadores.

Kovack e Love (2004), por sua vez, defendem que a principal característica do mediador é sua atuação não diretiva, sem tentar influenciar decisões e sim favorecendo o diálogo entre partes cujos conflitos impeçam a escuta e a alteridade, devendo o termo mediação ser utilizado para essa ação específica.

Os debates não parecem ter uma solução definitiva e é nesse clima de discussão que a mediação de conflitos chega ao Brasil no final dos anos 1980 e início dos anos 1990.

No entanto, experiências de intermediação já existiam no país. Desde as Ordenações do Reino, de 1480, há a previsão de conciliação em processos cíveis. Além disso, no século XVIII surgem os juízes de paz, leigos, eleitos pela população local com a função de promover a conciliação antes das decisões dos juízes de direito, nomeados pelo Imperador, em processos civis e criminais. Na área comercial, desde o século XIX, com o Código Commercial, de 1850, há a conciliação obrigatória antes do processo judicial (MARTINS FILHO, 1999).

São nos anos 1990 que a mediação surge como prática estruturada, integrando ações de políticas públicas. Nesse sentido, as primeiras experiências surgem com a mediação familiar interdisciplinar, ou seja, junto a saberes do direito e da psicologia, principalmente (BARBOSA, 2007) e também dentro de trabalhos relacionados à violência, em especial doméstica, como o trabalho de Muszback (2005), a partir de 1993.

Posteriormente, há a instituições da mediação na legislação trabalhista, como no Decreto n. 1.572, de 28 de julho de 1995, que regulamenta a mediação de conflitos no âmbito das negociações coletivas trabalhistas, bem como a Lei n. 10.101, de 19 de dezembro de 2000, que permite a mediação em caso de impasse nas negociações referentes à participação de trabalhadores nos lucros ou resultados das empresas (BRASIL, 1995 e 2000).

No entanto, é no projeto Balcão de Direitos, da ONG "Viva Rio", em 1996, que surge uma das primeiras experiências de mediação comunitária em bairros periféricos e favelas do Rio de Janeiro, com o objetivo de fortalecer as comunidades quanto a seus direitos e garantias (WARAT, 2004).

Enquanto isso, as discussões na Europa levam à realização da Conferência de Cleteil, "Mediação social e novas formas de resolução de conflitos na vida cotidiana", realizada no período de 21 a 23 de setembro de 2000, quando a União Europeia foi presidida

\footnotetext{
${ }^{4}$ No original: "Médiation sociale et nouveaux modes de résolution des conflits de la vie quotidienne".
} 
pela França. A conferência, organizada pela Comissão Europeia e pela Delegação Interministerial para a Cidade (Délégation Interministérielle à la Ville) da França, apresentou as diferentes formas de mediação (institucional, social, direcionada ao acordo, transformadora), que então floresciam e debateu sobre os caminhos da mediação a partir daí (MARCUS, 2003. FRANCE, 2000). O resultado foi, entre outros, a construção de uma definição de mediação social como:

[...] processo de criação e de reconstrução de laços sociais e de regulação dos conflitos da vida cotidiana, no qual um terceiro independente e imparcial, tenta, por meio da organização de trocas entre as pessoas ou as instituições, auxiliá-las a melhorar um relacionamento ou resolver um conflito que as opõem ${ }^{5}$ (FRANÇA, 2012).

Diante dessa consolidação, o modelo de mediação que se expande pela Europa, em especial para lidar com a questão da violência e das relações interculturais, é a social (OLIVEIRA e GALEGO, 2005). Ele integra um processo de desenvolvimento e de expansão da mediação de conflitos que permeou o século XX, em especial após a II Guerra Mundial, inserindo-se numa concepção de conflito permanente, de necessidade de restauração de laços sociais e de manutenção de relacionamentos. Esse é o modelo que fundamenta este trabalho por ser considerado o modelo mais adequado ao fenômeno estudado, uma vez que trata de questões como as áreas pobres, com violência e opressão econômico-social.

\subsection{Concepções}

Six (2001 e 2005), Warat (2001 e 2004), Bush e Folger (2005) e Costa (2003) consideram haver duas concepções de mediação.

A primeira é derivada de uma visão que compreende o conflito uma interrupção na harmonia natural da sociedade, uma patologia que precisa de tratamento. Diante dele, os processos de solução são centrados no apaziguamento, na resolução da disputa e no encerramento da situação conflituosa. Com relação à mediação, ocorre um processo de busca de um acordo, pois o conflito é percebido como problema, concepção encontrada em Riskin (2002) e Moore (1998), por exemplo.

Diante disso, o objetivo da mediação é o alcance de um acordo satisfatório, sendo a atuação do mediador direcionada ao apaziguamento, à construção do consenso e ao término do conflito. Esse modelo é chamado de tradicional, de Harvard, linear-tradicional,

\footnotetext{
5 Texto original: "La médiation sociale est un processus de création et de réparation du lien social et de règlement des conflits de la vie quotidienne, dans lequel un tiers impartial et indépendant tente, à travers l'organisation d'échanges entre les personnes ou les institutions, de les aider à améliorer une relation ou de régler un conflit qui les oppose"(Id. Ib. Loc. cit. itálico da autora).
} 
centrado no acordo, negociada, negociação assistida, centrada na resolução de problemas (SIX, 2001. WARAT, 2004. COSTA, 2003. BUSH; FOLGER, 2005).

Para se obter um entendimento mais claro dessa concepção é preciso considerar sua origem: apesar de ter sido estruturada e espalhada no ocidente a partir da experiência de Harvard, foi adaptada dos comitês de mediação popular chineses, concebidos dentro da escola dos ensinamentos de Confúcio (LUBMAN, 1962. COHÉN, 1966. GINSBERG, 1978. BROWN, 1982).

Nesse sentido, é preciso compreender também a concepção de sociedade dada por Confúcio. Conforme Wilhelm (LAO-TSU, 978), tanto os ensinamentos de Confúcio (551 a.C - 479 a.C) quanto de Lao-Tzu surgiram como formas de lidar com o período de caos e conflitos na China Antiga. No entanto, enquanto esse último via o movimento, a dialética, como a essência de todas as coisas, havendo a necessidade de um retorno à natureza, à simplicidade e a um não agir, para se evitar o caos e o sofrimento, o primeiro considerou que a ordem, a hierarquia e a ritualização da vida seriam o caminho correto para tanto. $\mathrm{O}$ ensinamento de Confúcio, assim, relaciona-se à regração social e à necessidade de se viver conforme a cortesia e o decoro à manutenção da harmonia social.

Conforme Bueno (2004) a sociedade harmônica, em Confúcio, viria da possibilidade de que todos seguissem as boas regras sociais e de uma relação de hierarquia baseada no respeito, na cordialidade e no fundamento da autoridade moral. Isso significa que a autoridade (o imperador, o irmão mais velho, o marido) teria o direito (e a responsabilidade) de decidir sobre os interesses do grupo (NADEOU, 2002. LUBMAN, 1967).

A estrutura do pensamento de Confúcio e toda a sua complexidade, inclusive em sua relação com os direitos humanos, não podem ser completamente compreendidas sem uma leitura profunda de seus ensinamentos, o que não é o objetivo do presente trabalho. Contudo, mesmo entre os autores que defendem essa relação, como fazem Bueno (2004), Nadeau (2002), Sim (2004) e Sang Jin (2010), não se nega que esses mesmos ensinamentos são utilizados na instituição de uma sociedade pautada pela busca da eliminação do conflito e da instituição da autoridade (LUBMAN, 1967).

Daí a mediação de conflitos, dentro dessa concepção, ser ritualizada, formalizada, burocrática, com faces processuais específicas e bem delimitadas, com o objetivo de alcançar uma harmonia social.

No entanto, ao se deparar com uma sociedade conflituosa, que rejeita a autoridade e a tradição, que tem entre dentro de sua formação as lutas e as revoluções sociais 
recentes, iniciadas pelas revoluções burguesas e constitucionais, bem como uma concepção de conflito como intrínseco à vida humana e social, tal mediação passa a ser questionada.

É nesse sentido que surge a segunda concepção, direcionada ao processo e às possibilidades de manifestação do conflito, ao desenvolvimento da autonomia e da autossuficiência da comunidade em detrimento do poder autoritário.

Dentro dessa vertente, encontram-se Warat (2004 e 2001), Bush e Folger (2005) e Six (2001), para quem a mediação deixa de considerar o acordo um fim em si mesmo e passa a focar a interação humana, a pluralidade, constituindo-se em um processo que enxerga o conflito como oportunidade de melhoria dos vínculos entre os envolvidos.

Isso não significa, contudo, que satisfazer interesses ou alcançar um acordo não seja importante. A questão colocada é que isso só deve se dar a partir da transformação das pessoas e dos conflitos, da compreensão das causas e dos reais objetivos envolvidos (BUSH e FOLGER, 2005). Ou seja, da análise dos elementos envolvidos no conflito.

\begin{abstract}
A mediação, portanto, não pode ser reduzida à busca de um acordo. O acordo é uma norma a ser cumprida, ainda que ela provenha de uma decisão consensual das partes conflitantes - ele põe fim a um litígio, mas resolver o litígio não implica transformar o conflito. A mediação busca tornar o acordo desnecessário, fazendo com que o conflito não gere incompatibilidades ou tentando sanar as incompatibilidades anteriormente estabelecidas. Trata-se, pois, de ajudar as partes a desenvolverem formas autônomas para lidar com as tensões inerentes ao seu relacionamento, e não de buscar acordos que dêem fim a uma controvérsia pontual (COSTA, 2003, s.p).
\end{abstract}

Para Warat (2004, p. 69) a mediação não tem o objetivo de realizar o acordo, mas de produzir a diferença, a alteridade ou "outridade reencontrada", ou seja, ela é vista como processo de construção de autonomia das pessoas em conflito. As decisões tomadas são dos próprios envolvidos, cabendo ao mediador direcionar o processo para facilitar o diálogo, a escuta, a compreensão do outro e a promoção da pluralidade e não para um acordo. $\mathrm{O}$ mediador não opina nem sugere, mas favorece a criação de um ambiente em que as próprias partes descubram o que desejam realizar:

A mediação consiste em manter integralmente os dois termos [as duas partes]. $\mathrm{O}$ mediador é um terceiro que age de tal maneira que os dois termos não somente preservam sua identidade, mas saem da mediação com a identidade reforçada, porque puderam, graças à presença do mediador, se confrontar um com o outro e evitar, nessa confrontação, ser absorvidos um pelo outro, em uma fusão ou uma derrota (SIX, 2001, p. 235).

Isso, no entanto, não significa que a mediação seja o melhor método. Conforme Deutsch (2004) não existe um método melhor ou pior que o outro. A escolha desse modelo relaciona-se ao objeto de estudo, condição necessária para o alcance dos objetivos propostos. 


\subsection{A mediação social}

A expressão "mediação social” é, assim como a própria mediação, polissêmica. Pontes (1997), por exemplo, vai considerar que ela é uma categoria do método dialético, dentro da teoria marxista, relacionada ao processo de conhecimento e intervenção do assistente social. Com isso, ela organiza a metodologia de intervenção do profissional e auxilia na inserção social de usuários nos serviços públicos.

No entanto, o conceito aqui adotado não possui tal conotação. Ele se relaciona à mediação de conflitos, já conceituada, contudo dentro de uma acepção específica, a partir de agora melhor explicitada. Nesse sentido, cabe já esclarecer que tal mediação pode ser chamada de popular ou comunitária.

A mediação popular, conforme Veloso, Amorim e Leonelli (2009), é uma terminologia adotada pela ONG "Juspopuli Escritório de Direitos Humanos", da Bahia, e está relacionada a uma mediação comunitária, em bairros populares, que atende pessoas carentes e sem acesso ao Poder Judiciário. A opção pelo uso da palavra popular ao invés de comunitário representa uma ação política, pois:

[...] sugere dupla interpretação: por um lado, pelo que se liga às opressões que retiram das pessoas a cidadania; do outro lado, a concepção se vincula a uma postura política de resistência das pessoas a essa ordem excludente (VELOSO, AMORIM e LEONELLI, 2009, p. 69).

Assim, o uso de tal expressão serve para diferenciar de uma mediação centrada apenas nas relações entre vizinhos e na prevenção de processos judiciais, priorizando seu objetivo de transformação social.

Já o termo "comunitária" pode servir a ações de pacificação ou de emancipação, conforme a experiência norte-americana. Em contrapartida, a experiência europeia, em especial nos países de línguas latinas, passaram a utilizar o termo "social" ao lidar com conflitos inter-culturais, inter-raciais, escolares, públicos ou ambientais (SOUZA, 2003. OLIVEIRA; GALEGO, 2005). Em outras palavras, a mediação social relaciona-se à:

[...] perspectiva de estender o campo e o uso da mediação para além da busca de acordos mutuamente satisfatórios entre disputantes, dirigindo-se à prevenção de conflitos, à promoção da saúde do tecido social e à convivência positiva, pressupondo o mundo como multicultural e multifacetado (SOUZA, 2003, p. 93).

Além disso, a partir da Conferência de Creteil (2000), na França, o termo social passou a ser oficialmente utilizado em oposição a uma mediação que Marcus (2003) chama de "tradicional", a fim de enfatizar o empoderamento individual na manutenção da harmonia social e na prevenção da criminalidade. Assim, a opção pelo termo mediação social, no 
presente trabalho, enfatiza sua relação com processos de transformação social, conforme previsto em seu conceito.

Dentro dessa concepção, o mediador social possui atribuições específicas que vão além das funções de mediador de conflitos uma vez que ele deve atuar sempre na identificação de grupos vulneráveis facilitando o seu acesso aos serviços públicos e a conscientização de seus direitos (FRANCE, 2011; 2008; 2009). Além disso, diante de conflitos sociais, ele tem ainda a atribuição de organizar reuniões com moradores ou instituições a fim de permitir a livre expressão, rastrear ou reduzir expectativas, compreender restrições e propostas para melhorar a vida cotidiana (FRANCE, 2009; 2011).

Contudo, sua atuação não pode ser solitária, pois muitos dos conflitos por ele enfrentados exigem a atuação de terceiros. Diante disso, o mediador social tem como função atuar junto a uma rede social e de proteção, acessando-a quando necessário, inclusive para garantir a continuidade dos serviços (FRANCE, 2009). Isso não significa que ele possa substituir os profissionais dos serviços sociais, ou seja, psicólogos, assistentes sociais ou educadores especializados, mas, ao contrário, provocar a atuação desses profissionais (FRANCE, 2011).

Dessa forma, em consonância com SIX (2001), a mediação social é uma ação política, relacionada, portanto, à democracia e à cidadania.

Sua relação com a democracia dá-se porque, ao permitir o diálogo, ela auxilia na convivência com a conflituosidade inerente à vida. Seu processo dialógico, pautado na escuta e na compreensão do outro, permite a realização do que Warat (2004) vai considerar negociação da produção conjunta da diferença, que em outras palavras pode ser compreendida como a vida comum (ARENDT, 2005) ou a partilha do sensível (RANCIÈRE, 1996).

Isso porque no processo de mediação social cada um dos participantes pode falar, ouvir, ser ouvido e se ouvir. Quando isso ocorre, as pessoas podem se colocar no lugar do outro e se permitir o reconhecimento desse outro e de suas diferenças. Com isso, o conflito passa a ser percebido como integrante da vida comum, atuando, então, como motor de transformação das pessoas diante dos conflitos (BUSH; FOLGER, 2005. WARAT, 2004).

Nesse ponto, ao incluir todos e favorecer o diálogo, a mediação social permite a participação dos que tradicionalmente não são ouvidos, de forma que possam ter um espaço de fala e de reivindicação (SIX, 2001. WARAT, 2004). Ademais, dentro de uma vertente social, a mediação permite que conflitos inicialmente compreendidos como apenas interpessoais possam ser vistos a partir de suas reais causas, tornando-se, assim, conflitos 
sociais (BUSH e FOLGER, 2005). Quando isso ocorre, a mediação social atua como um espaço de promoção da cidadania.

Cidadania, aqui, não é apenas o vínculo político com um Estado. Ela está relacionada, conforme Six (2001), às “coisas da cidade”, à participação e à atuação no bairro, nas associações, na vida comunitária, e a uma identificação pessoal criada a partir de ligações emocionais com as pessoas, com o lugar, com os costumes, com uma cultura e, mais ainda, com a obrigação de servir à própria comunidade.

Warat (2004, p. 113) compreende a cidadania como uma mudança no modo de conceber a vida cotidiana: não é uma existência de um e de outro, mas um "espaço entre um e o outro", uma decisão construída com o outro, um espaço construído dentro das relações interpessoais que se constitui na responsabilidade, no cuidado, na solidariedade.

Para Jelin (2007), ela se relaciona a um compromisso com o mundo, a um agir guiado pela consciência pessoal, pela sensação do justo e do ético.

Diante disso, cidadão é o próprio sujeito de direitos da EDH. Daí sua relação com a mediação social. Em outras palavras, o próprio mediador social é cidadão e sujeito de direitos isto é, ele encontra pessoas em conflito, atua de forma ética, favorece os recursos das próprias partes, sem impor, nem sugestionar, mas buscando as causas reais do conflito em questão. Ao perceber um aspecto social, age no sentido de empoderamento das partes para uma atuação conjunta. Além disso, ele é um sujeito de direitos porque tem a responsabilidade de atuar ativamente em sua comunidade, especialmente como ponte para os demais e entre esses e os serviços públicos, seus direitos e suas garantias (SIX, 2001).

Assim, a mediação acaba por se tornar um espaço de reconhecimento, no qual as pessoas podem decidir sobre suas próprias vidas, sem a necessidade de decisões heteronômicas. Isso representa a possibilidade de promoção de autonomia dos sujeitos e dos grupos envolvidos (WARAT, 2004. CASTORIADIS, 1982).

Em suma, pelo processo de mediação social tanto a autonomia, quanto a democracia e a cidadania podem ser desenvolvidas, o que a leva a ser considerada uma proposta pedagógica e cultural, que se propõe "transformadora da sensibilidade individual e coletiva, e que está afetando todos os modos de entender tanto as ações públicas como os vínculos privados, e fundamentalmente, as relações amorosas" (WARAT, 2004, p. 104):

Em termos de autonomia, cidadania, democracia e direitos humanos a mediação pode ser vista como a sua melhor forma de realização. As práticas sociais de mediação configuram-se em um instrumento de exercício da cidadania, na medida em que educam, facilitam e ajudam a produzir diferenças e a realizar tomadas de decisões, sem a intervenção de terceiros que decidem pelos afetados em um conflito. Falar de autonomia, de democracia e de cidadania, em um certo sentido, é ocupar-se 
da capacidade das pessoas para se autodeterminarem em relação e com os outros; autodeterminarem-se na produção da diferença (WARAT, 2004, p. 66).

Apesar disso, a atuação da mediação social dentro do contexto escolar pode apresentar-se de forma diferenciada.

\subsection{A mediação no contexto escolar}

As experiências mais antigas de mediação de conflitos no contexto escolar remontam à década de 1970. O primeiro programa noticiado é o Children's Creative Response to Conflitc (CCRC), criado em 1972 na cidade de Nova Iorque, Estados Unidos, a partir da extensão do projeto de mediação comunitária local, o New York Quaker Project on Community Conflict (HEREDIA, 2009. JARES, 2002). Apesar disso, tanto Finn (1995) quanto Sorel (1955) mencionam que a experiência iniciou-se em 1968, a partir da experiência com o treinamento de integrantes de peacekeping (manutenção da paz) da ONU (2014).

Conforme Sorel (1995), a percepção gerada diante da atuação com tropas de manutenção da paz levou a considerar a necessidade de se educar as crianças para valores pacifistas e não violentos. Contudo, havia a percepção de que mesmo os professores e demais educadores não eram preparados para lidar com essa mudança (PRUTZMAN et al, 1978).

$\mathrm{O}$ projeto foi direcionado às escolas de ensino fundamental com o objetivo inicial de propagar valores de não-violência e desenvolver habilidades sociais para lidar com conflitos (FIN, 1995. JARES, 2002. PRUTZMAN et al., 1978). De forma estruturada, Heredia apresenta os objetivos da seguinte forma:

a) desenvolver uma comunidade em que as crianças desejem e sejam capazes de uma comunicação aberta; b) ajudar às crianças a desenvolver uma melhor compreensão da natureza dos sentimentos, capacidades e fortalezas humanas; c) ajudar às crianças a compartilhar seus sentimentos e ser conscientes de suas próprias qualidades; d) ajudar a cada criança a desenvolver autoconfiança em suas próprias habilidades e e) pensar criativamente sobre os problemas e começar a prevenir e solucionar os conflitos (HEREDIA, 2009, p. 52).

Diante disso, o currículo era organizado em quatro eixos: cooperação, comunicação, resolução de conflitos e afirmação e desenvolvimento de auto-estima, trabalhados tanto junto às crianças quanto aos professores (SOREL, 1995).

A formação dos professores era direcionada a habilidades de metodologias de cooperação bem como para usar e ensinar habilidades de administração de conflitos, a fim de

6 No original: "a) desarrollar una comunidad em la que los niños deseen y sean capaces de uma comunicación abierta, b) ayudar a los niños a desarrollar uma mejor compreensión de la naturaleza de los sentimientos, capacidades y fortalezas humanas, c) ayudar a los niños a compartir sus sentimientos y ser conscientes de sus proprias cualidades, d) ayudar a cada niño a desarrollar autoconfianza em sus próprias habilidades, e) a pensar creativamente sobre los problemas y comenzar a prevenir y solucionar los conflictos" (Id. Ib. Loc. cit. itálico da autora). 
impactar positivamente o ambiente de aprendizado, tanto na sala de aula quanto na escola como um todo (FINN, 1995). Em relação às crianças, eram orientadas a desenvolverem habilidades de comunicação e cooperação, havendo destaque ao desenvolvimento da autoestima (SOREL, 1995. PRUTZMAN et al, 1978).

Essa experiência inicial favoreceu a criação de outros programas, dentre esses, o programa Conflict Resolution Resources for Shool and Youth (CRRSY). Criado em 1976, em São Francisco, também nos Estados Unidos, integra desde 1982 o programa Community Boards: Building Community Through Conflict Resolution, de mediação comunitária (HEREDIA, 2009. COMMUNITY BOARDS, 2010).

Esse programa se diferencia do anterior, primeiramente, porque sua atuação se dá a partir da colaboração entre o sistema escolar e os centros de mediação comunitária local, cabendo a esses a formação e o auxílio na implementação do programa nas escolas. Além disso, ele se diferencia do anterior por possuir currículos para todos os níveis educacionais, a partir dos 03 anos de idade (HEREDIA, 2009. COMMUNITY BOARDS, 2010).

Dentro dessa proposta, o objetivo era desenvolver habilidades em administração de conflitos com foco no relacionamento entre pares. Daí seu direcionamento ao treinamento de estudantes como mediadores de conflitos (COMMUNITY BOARDS, 2010. HEREDIA, 2009). É, assim, uma visão mais prática e de curto prazo que o primeiro.

A partir desses dois programas pode-se perceber que a mediação de conflitos no contexto escolar não surge dentro de uma ação pedagógica, interna à lógica escolar, mas do próprio movimento de expansão da mediação de conflitos como prática social. Além disso, ela também coincide com o processo de massificação da escolarização e de instituição da escola dos paradoxos que retira de si as funções educativas.

Dessas experiências é que a mediação de conflitos expandiu-se no contexto escolar. Apesar disso, Slyck e Stern (1991) consideram haver apenas duas categorias desse tipo de programa: uma de longo prazo, mais global, e outra de curto prazo.

A primeira, representada pelo CCRC, tem como objetivo promover melhores cidadãos e um mundo mais harmonioso, em que as relações estariam sujeitas a formas não violentas de resolução de conflitos. A segunda categoria, representada pelo CCRSY, tem uma função mais programática e de curto prazo, de tornar os estudantes mais socialmente engajados e melhorar o clima disciplinar escolar.

Dentro desses dois modelos podem ser desenvolvidos quatro enfoques práticos, conforme expressam Crawford e Bodine (1996). 
O primeiro enfoque relaciona-se aos programas simplesmente curriculares, ou seja, aulas ou um curso específico com objetivos de mudar atitudes e comportamentos dos estudantes diante do conflito, tornando suas abordagens mais colaborativas. Dentro desse contexto, o programa pode variar desde a discussão quanto às formas de resolver conflitos ao redor do mundo até o enfoque de desenvolvimento de habilidades práticas, como escuta ativa, comunicação eficaz e técnicas de solução de problemas (HEREDIA, 1999 e 2008. CRAWFORD; BODINE, 1996).

O segundo enfoque trata da mediação de conflitos estrito senso, ou seja, com objetivo de capacitar adultos e (ou) estudantes para se tornarem mediadores. Entre esses, pode haver desde a mediação por pares pelos estudantes, para resolver os conflitos entre colegas, nos pátios, recreios ou salas de aula, bem como a comediação entre professores e alunos para lidar com conflitos entre estudantes e professores, além de programas nos quais os adultos são os mediadores (CRAWFORD; BODINE, 1996. HEREDIA, 1998 e 2008).

O terceiro enfoque se dá dentro da construção de aulas colaborativas. Nele, o objetivo é que toda a metodologia de ensino desenvolva-se a partir do trabalho cooperativo, já mencionado nesta pesquisa. Isso significa que uma educação em resolução pacífica de conflitos é incorporada aos objetivos do currículo e às estratégias de administração de sala de aula, havendo, para isso, a capacitação específica de professores para a atuação dentro desse enfoque (HEREDIA, 1999 e 2008; CRAWFORD; BODINE, 1996).

Por fim, há o enfoque da escola pacífica (peaceable school approach) na qual, os "princípios e processos da resolução de conflitos são aprendidos e utilizados por todos os membros da comunidade escolar: bibliotecários, professores, conselheiros, diretores e pais ${ }^{7}$ " (CRAWFORD; BODINE, 1996, p. 39). É o chamado "enfoque global”, de Heredia (2008), que envolve todos os demais, de forma a influenciar as seguintes áreas escolares: o sistema disciplinar, o currículo, a pedagogia, a cultura, o lugar e a comunidade (HEREDIA, 2008). Essa é a abordagem proposta por Ortega e Del Rey (2002) ao considerarem que ele oferece melhores resultados no sentido de prevenção de violências nas escolas, estando em consonância com a proposta de desenvolvimento de fatores de proteção de Debarbieux (2006), além de ser uma proposta compartilhada por Crawford e Bodine (1996) e Heredia (2008 e 2009).

\footnotetext{
${ }^{7}$ No original: Conflict resolution principles and processes are learned and utilized by every member of the school community—librarians, teachers, counselors, students, principals, and parents (Id. Ib. Loc. cit. itálico da autora).
} 
Em relação ao sistema disciplinar, a mediação interfere ao alterá-lo de um sistema punitivo para de autorregulação e de compreensão das consequências dos atos. Nesse sentido, o processo de mediação pode ser tanto anterior quanto posterior às consequências disciplinares, podendo ainda substituir completamente o modelo punitivo (HEREDIA, 2006).

Quanto ao currículo, o enfoque global o influencia ao incorporar os conceitos e as habilidades de resolução de conflitos, seja como um curso específico, seja pela incorporação em temas transversais. Ao mesmo tempo, ele influencia a pedagogia ao incentivar o uso de ferramentas colaborativas no ensino em sala de aula (HEREDIA, 2008).

É importante que haja a institucionalização de métodos de resolução pacífica de conflitos em todo o sistema escolar, influenciando a atuação de todos os atores da comunidade escolar. Isso porque, conforme Heredia (2008), os adultos também possuem pouca preparação, treinamento ou disposição para lidar de maneira cooperativa diante dos conflitos. Se não há a institucionalização, não há consequências reais, porque não há efetiva transformação das relações sociais.

Nesse contexto, é preciso compreender ainda que muitos dos conflitos que envolvem a escola originam-se fora dela. Daí a importância do envolvimento de outros membros da comunidade: corpo policial, religioso, associações comunitárias, entre outros (HEREDIA, 2008). Por isso a importância da inserção da escola na própria comunidade.

A partir desses enfoques é que a mediação de conflitos no contexto escolar expandiu-se por diversos países, integrando a mediação social. Dentro do contexto social, a mediação na escola passou a ter como objetivo principal o fortalecimento dos laços entre escola, comunidade e família, principalmente aquela em situação de vulnerabilidade, evitando a evasão escolar e promovendo a participação na escola. Isso sem esquecer a atuação em prol da melhoria das relações internas na escola como um todo (FRANCE, 2011). Para tanto, ela envolve quatro eixos.

O primeiro refere-se ao mediador dos conflitos entre usuários e o serviço público, sendo uma atuação junto às administrações escolares centrais (ministérios, departamentos, secretarias, divisões, conforme o termo aplicado). O segundo trata da relação entre a escola e a família, com a finalidade de aproximar essas duas instituições. No terceiro atua o mediador de desempenho acadêmico (médiateur de réussite scolaire), com o objetivo de acompanhar o desenvolvimento dos estudantes e permitir intervenções rápidas em caso de queda de rendimento. No quarto e último eixo atua o mediador escolar, para gerir os conflitos no ambiente escolar (FRANCE, 2011. SIX, 2001 e 2005). 
Isso não significa que, na mediação social, haja a obrigatoriedade de que cada eixo seja atribuído a um mediador diferente, mas que os programas existentes devem abarcar tais eixos.

No Brasil, a primeira experiência de mediação escolar foi o programa "Escola de Mediadores”, em 2001, em escolas públicas no Rio de Janeiro, realizado em parceria pelas ONGs Viva Rio, Balcão de Direitos, Mediare e o Instituto NOOS (SALES 2007. CARTILHA DE MEDIADORES, 2002). Também aqui a experiência nasce de instituições externas à escola, vinculadas à mediação de conflitos, em especial a mediação comunitária e direcionada à atuação frente a violências ou como forma de prevenção, sendo seu objetivo:

ensinar (transmitir) algumas habilidades aos jovens para negociar os conflitos inevitáveis que ocorrerão nos diversos contextos de suas vidas de forma mais colaborativa, propiciando uma mudança de postura frente às controvérsias (CARTILHA DE MEDIADORES, 2002, p. 06).

A finalidade do programa era a formação cidadã de alunos e o incentivo ao surgimento de uma mentalidade colaborativa e não violenta na resolução de conflitos. Para tanto, ele teria trabalhado com vários atores da comunidade: professores, estudantes, família, concluindo com a formação de uma equipe de jovens mediadores para atuar no dia a dia escolar.

Após esse programa, diversas outras experiências surgiram no Brasil, entre elas o Projeto de Extensão e Ação Contínua (PEAC) "Estudar em Paz: mediação de conflitos no contexto escolar", do Núcleo de Estudos para a Paz (NEP) da Universidade de Brasília (UnB), que será apresentado no capítulo a seguir. 
PARTE II -

Aspectos Teórico-Metodológicos 


\section{ASPECTOS TEÓRICO-METODOLÓGICOS}

O desenvolvimento de uma pesquisa perpassa as idas e vindas, a escolha do objeto de estudo, o pensamento sobre o método, o questionamento sobre as estratégias mais adequadas, o olhar a direcionar a forma de ver o objeto, tal como expressa Bell (2004), e todo um referencial teórico que fundamentará o trabalho a ser desenvolvido.

O objetivo geral deste trabalho foi avaliar o Projeto de Extensão e Ação Contínua (PEAC) "Estudar em Paz: mediação de conflitos no contexto escolar", desenvolvido pela Universidade de Brasília (UnB), no período de 2010 a 2013, numa escola pública do Distrito Federal.

As escolhas que se seguiram foram sempre realizadas tendo-se isso em mente. No entanto, elas não foram fáceis, pois minha relação com o a partir de então chamado simplesmente "Projeto Estudar em Paz" e com alguns de seus membros, vai além da relação pesquisador-pesquisado. Isso porque tenho um lugar de fala nesse projeto, pois fui uma de suas fundadoras, juntamente com a atual coordenadora-executiva, no ano de 2009. Assim, a minha relação com ele tem o condão de ser a mesma entre criador e criatura e, com seus participantes, uma relação de parceria.

Contudo, também não posso negar meu posterior afastamento. Eu sequer o acompanhei à distância. Assim como já dizia Heráclito, a vida é movimento, e um movimento tal que é capaz de nos tornar estrangeiros em nossa própria terra. E esse é o olhar que me vi desenvolver ao longo de todo este trabalho.

Dessa forma, compreender o meu objeto de estudo na sua práxis atual, discorrer sobre ele, avaliá-lo, enfim, foi uma tentativa de compreensão dos movimentos que ele foi tomando ao longo do tempo. Os caminhos e escolhas desta pesquisa são, então, uma tentativa de organizar essa compreensão. Escolhas e caminhos que serão apresentados a seguir, primeiramente para justificar a opção pelo estudo de caso único e, em seguida, para apresentar os métodos de geração de dados, bem como os percursos percorridos em cada um deles. Por fim, apresento as condições éticas da pesquisa e concluo discorrendo sobre meu objeto de estudo e do campo no qual se desenvolveu esta pesquisa.

\subsection{Um estudo de caso único}

A pergunta orientadora desta pesquisa é: se, diante da realidade apresentada sobre o "Projeto Estudar em Paz", a mediação de conflitos pode contribuir para o 
desenvolvimento de uma cultura de paz e de direitos humanos, constituindo-se numa ação efetiva de prevenção de violências no contexto escolar.

Considerando que se buscava uma compreensão do fenômeno, a escolha de uma abordagem qualitativa e, dentro dela, de um estudo de caso, mostrou-se a mais apropriada, principalmente ao se considerar o que Yin (2001) expressa, ou seja: essa é a abordagem mais adequada quando a intenção é compreender um fenômeno que é por si mesmo complexo, de forma que as explicações causais sejam feitas com profundidade. $\mathrm{O}$ objetivo é compreender as condições contextuais do objeto de estudo.

A partir da escolha da abordagem, outras escolhas se seguiram. Primeiramente, considerando-se que o objeto estudado tem se desenvolvido em várias escolas, seria possível realizar um estudo de caso múltiplo, objetivando uma avaliação que chegasse a um grau de confiabilidade estatística de 95\%, conforme apregoado por Borges (2007). No entanto a especificidade de um caso específico e não-aleatório seria perdida, da mesma forma como se perderia o aspecto holístico do objeto de estudo (YIN, 2001). Além disso, o estudo de caso múltiplo dificultaria o cumprimento da agenda de trabalho, que teve de se adaptar ao calendário escolar e todos os percalços que isso significa. Daí a escolha por uma única escola a ser pesquisada, chamada então de "escola pesquisada".

É bem verdade que cada escola possui suas peculiaridades e a escolha de uma única, num universo plural, para o desenvolvimento de uma pesquisa sobre a implementação de um projeto, pode suscitar questões sobre a validade das percepções encontradas.

Nesse sentido, conforme Borges (2007, p. 08), as críticas ao estudo de caso único podem ser: a impossibilidade de se testar todas as causas hipotéticas, gerando possibilidades de falsificação de proposições; a possibilidade de produção de amostras enviesadas; a impossibilidade de generalizações e de compreensão de um "mundo social governado por leis probabilísticas".

Contudo, o mesmo autor lembra que todas as pesquisas estão sujeitas a enviesamentos e questionamentos quanto a sua validade conceitual, daí a importância da combinação de mais de um método de construção de dados e de análise, o que Bell (2004) chama de triangulação, e uma "maior explicitação dos critérios de escolha dos casos, bem como uma maior preocupação com o escopo da explicação" (BORGES, 2007, p. 14).

Ademais, é preciso lembrar que o principal benefício de um estudo de caso único é justamente aprofundar a análise de um fenômeno não aleatório, não sendo o objetivo central a generalização das hipóteses (BORGES, 2007). Ainda assim, Yin (2001) considera que o estudo de caso único pode permitir uma generalização quanto a questões teórica, ou 
seja, a expansão e generalização da teoria e não de amostras ou populações. Para tanto, o essencial é justamente a preparação e a organização da pesquisa, com suas bases metodológicas, aliado à justificação de seu escopo e das escolhas realizadas.

Com isso, cabe esclarecer que a escolha da escola pesquisada se deu por ser ela a mais antiga no "Projeto Estudar em Paz" à época em que se iniciou este estudo. Partiu-se do pressuposto que, diante disso, ela apresentaria uma gama de conflitos e contradições que permitiriam uma análise profunda para o alcance dos objetivos aqui propostos.

O período estudado, de 2010 a 2013, foi escolhido por abranger o início da implantação do PEAC na UnB e o tempo máximo possível para a realização da pesquisa dentro dos prazos do mestrado. Não foi feita uma seleção temporal menor para abarcar movimentos de mudanças dentro da escola pesquisada, isto é, as mudanças da práxis.

\subsection{A geração dos dados}

Analisar a complexidade de um fenômeno é desafiante, principalmente se ele está ainda em movimento, sujeito a todas as influências de seu meio. Assim, para organizar esse desafio foi utilizada a triangulação, isto é, a combinação de um conjunto de técnicas que propicia uma maior confirmação dos dados (BELL, 2004). Diante disso, no presente trabalho, as técnicas utilizadas para a construção dos dados foram grupo focal, entrevistas, documentos, e notas de campo.

\subsubsection{O grupo focal}

Grupo focal é uma "entrevista coletiva que busca identificar tendências" (COSTA, M.E.B 2005, p. 181), com "alto poder analítico" caracterizado pela:

[...] possibilidade de intervenção em tempo real no curso da análise e de confrontar as percepções de participantes em suas similitudes e contradições a respeito de um tema, ou grupo de temas, relacionados com o objeto de pesquisa. Enfatiza-se por meio dessa técnica não apenas as percepções individuais, mas também aquelas oriundas das interações do coletivo, expressas nas estruturas discursivas e na defesa ou crítica de temas e aspectos relevantes da pesquisa (RUEDIGER; RICCIO, 2004, p. 151).

Para Morgan (1997) ele é importante para aprofundar reflexões, verificar valores, princípios, motivações, compreender o que aconteceu e aprender lições para o futuro. Ele é também recomendado quando "a troca de impressões enriquece o produto esperado, quando se quer aprofundar o conhecimento de um tema" (COSTA, M.E.B 2005, p. 182) e perceber "nuanças pouco percebidas ex ante" (RUEDIGER; RICCIO, 2004, p. 154). 
Além disso, para Morgan (1997), o grupo focal permite o acesso a dados e a conteúdos que não seriam permitidos de outra forma, num curto espaço de tempo, com profundidade, por meio da interação entre participantes e ainda dentro de certo controle por parte do pesquisador. Esse foi o motivo pelo qual esse método foi escolhido.

Diante disso, foi projetada a realização de três grupos focais, dois envolvendo profissionais e alunos da escola pesquisada e um terceiro com os integrantes do "Projeto Estudar em Paz", constituindo-se num grupo focal segmentado por funções, isto é, formado por pessoas conhecidas entre si (MORGAN, 1997). Apesar disso, foi realizado apenas um dos grupos inicialmente previstos: com os estudantes da escola pesquisada.

Autores como Russel et al. (2008), Westpltal, Bogus e Faria (1996) e Morgan (1997) mencionam a necessidade de se unir o grupo focal a um outro método para se obter uma melhor avaliação da interação do grupo e também para contornar as fragilidades presentes. Esse método deve ser prévio à realização do grupo, tendo sido escolhida, para a presente pesquisa, a entrevista semiestruturada.

Compatibilizar a agenda com a dos entrevistados, contudo, mostrou-se mais delicado do que o inicialmente imaginado. Isso porque o meu contato com a escola só pode se iniciar em $1^{\circ}$ de outubro de 2013. Além disso, o trabalho de campo só se iniciou 25 dias depois, após os procedimentos de autorização, tendo de ser encerrado em 19 de dezembro.

Nesse período, apesar de a escola se mostrar aberta à pesquisa, foi difícil conversar com professores e alunos em razão das faltas, justificadas ou não, dos professores.

Não desejo entrar aqui no mérito das ausências, mas no impacto delas para a pesquisa, pelo fato de tais ausências significarem a impossibilidade de entrevistar os faltosos (por óbvio), como também os professores restantes e os alunos. Quanto aos professores presentes, alguns precisavam "subir" aula, isto é, ficar responsáveis pelas turmas dos faltosos. Se a turma fosse liberada, por outro lado, era impossível conversar com os alunos, pois não aceitavam ficar mais tempo na escola. E, com os alunos liberados, os professores até então presentes também iam embora, caso não houvesse mais turmas para atender.

Essas situações fizeram com que o período de entrevistas fosse se prolongando até o último dia disponível, tornando inviável a realização do grupo focal com os profissionais da escola. Cabe esclarecer ainda que, apesar de eu estar presente até o dia 19 de dezembro de 2013 na escola, a semana que antecedeu a essa data foi uma semana infrutífera, direcionada mais a entrega de notas ou provas de recuperação.

Em relação ao grupo focal com os participantes do "Projeto Estudar em Paz", o momento de encontro com eles era fixo: às terças feiras, à tarde, no Núcleo de Estudos para 
a Paz e os Direitos Humanos (NEP), para reunião de coordenação. Meu planejamento inicial levou esse dado em consideração.

No entanto, só ocorreram duas reuniões do grupo no segundo semestre de 2013. Os contatos entre os membros do grupo se deram principalmente via rede social. Isso fez com que eu tivesse um número insuficiente de participantes para a realização do grupo focal.

Diante disso, foi realizado o grupo focal apenas com a participação de estudantes da escola pesquisada que participaram do "Projeto Estudar em Paz" durante o recorte temporal estabelecido. A reunião aconteceu com 05 alunas, de 13 a 14 anos. Dois alunos apareceram, mas, após as explicações, não desejaram participar.

O encontro ocorreu na escola pesquisada, numa sala de aula disponível. Apesar de não ser um "local neutro", conforme sugerido por Morgan (1997), Costa M.E.B (2005) e Ruediger e Riccio (2004), era um local de fácil acesso e ponto de encontro de todos os participantes. Sua duração, descontados o período de explicação do processo, a solicitação de autorização para uso na pesquisa, os agradecimentos e as despedidas, foi de $1 \mathrm{~h} 30 \mathrm{~min}$ e seguiu um roteiro semiestruturado, do tipo "funil", ou seja, iniciado com perguntas gerais e indo aos poucos para perguntas fechadas e específicas à realidade que se quer estudar (MORGAN, 1997. RUEDIGER; RICCIO, 2004. COSTA, M.E.B 2005).

A opção pelo modelo semiestruturado, ou seja, aquele que segue um roteiro, mas permite que outras questões sejam incluídas conforme o debate desenvolvido, deu-se porque tal procedimento permite "elucidar e aprofundar a investigação em uma dialética com as respostas e opiniões emitidas" (RICCIO e RUEDIGER, 2004, p. 155). Assim, a primeira parte da seção teve como objetivos identificar a percepção dos participantes sobre a escola pesquisada, analisar os conflitos e as violências existentes; identificar as formas de tratamento que a escola dá a esses conflitos e violências. A segunda parte teve o objetivo de verificar a percepção sobre o objeto de pesquisa, em especial quanto a expectativas, impactos, dificuldades, pontos positivos e negativos e ainda a implantação e o desenvolvimento do "Projeto Estudar em Paz" na escola pesquisada.

Como toda técnica de construção de dados, o grupo focal possui fragilidades, centradas na interação do grupo e na atuação do pesquisador. Morgan (1997, p. 14) enfatiza que as respostas dadas dentro do grupo podem ser diferentes das respostas em entrevistas individuais, sendo possível que o pesquisador ou um integrante "mais exuberante" (Costa, M.E.B 2005, p. 182) influencie a interação do grupo e, assim, o próprio resultado da pesquisa. 
Daí a importância de unir o grupo focal a algum outro tipo de método de coleta de dados bem como de planejamento e de preparação das pesquisas. Nesse sentido, os outros métodos utilizados foram as entrevistas, a análise documental e as notas.

\subsubsection{Entrevistas}

Como técnica de construção de dados, a entrevista é a mais utilizada nas ciências sociais, sendo considerada "a técnica por excelência na investigação social" por possibilitar "a obtenção de dados referentes aos mais diversos aspectos da vida social" (GIL, 2012, p. 113 e 114).

Os objetivos da entrevista foram os mesmos descritos no grupo focal, tendo sido realizadas, ao todo, 30 entrevistas organizadas em três grupos: estudantes, profissionais da escola pesquisada e participantes do "Projeto Estudar em Paz". A Tabela 8 e o Gráfico 2, a seguir, apresentam o quantitativo total e por segmentos, respectivamente:

Tabela 8 - Quantitativo total e por segmento de entrevistados

\begin{tabular}{|c|c|}
\hline Grupos & $\begin{array}{c}\text { No. De } \\
\text { entrevistados }\end{array}$ \\
\hline Estudantes & 10 \\
\hline Profissionais da escola & 13 \\
\hline Participantes do projeto & 7 \\
\hline Total & 30 \\
\hline
\end{tabular}

Fonte: Dados da Pesquisa / Excel

Gráfico 2 - Proporção do quantitativo total de entrevistados por segmento

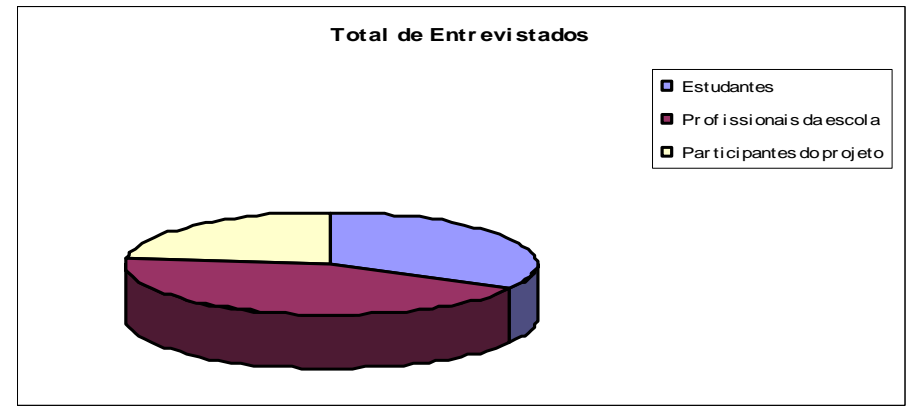

Fonte: Dados da Pesquisa / Excel

Houve a previsão de entrevistas com pais, mães e demais responsáveis dos estudantes da escola pesquisada bem como com servidores e outros profissionais, como terceirizados, responsáveis pela limpeza e pela segurança, pois os objetivos do "Projeto Estudar em Paz" previam a formação de mediadores sociais também nesses grupos.

No entanto, verificou-se no decorrer da pesquisa que esses segmentos não foram atendidos, ao menos na escola pesquisada. Diante disso, eles foram desconsiderados para fins de entrevistas, tendo sido realizada apenas uma entrevista com um profissional da 
segurança, enquadrado posteriormente como "profissional da escola", que, mesmo não tendo participado do "Projeto Estudar em Paz", dele tinha conhecimento e desejou ser entrevistado.

Assim, na escola pesquisada, foram realizadas 23 entrevistas semiestruturadas, sendo 10 com os estudantes, com idade compreendida entre 13 e 16 anos, todos participantes de curso de formação de mediadores sociais, sendo 04 do sexo masculino e 06 do sexo feminino, conforme demonstra a Tabela 9:

Tabela 9 - Grupo de estudantes conforme o sexo

\begin{tabular}{|l|c|}
\hline Sexo & Quantitativo \\
\hline Feminino & 06 \\
\hline Masculino & 04 \\
\hline Total & 10 \\
\hline
\end{tabular}

Fonte: Dados da Pesquisa

Dentro da categoria "profissionais da escola" foram realizadas 13 entrevistas sendo: 03 pessoas do sexo masculino e 10 do sexo feminino, divididos entre direção, coordenação, professores e terceirizado, conforme indicam as Tabelas 10 e 11:

Tabela 10 - Profissionais da escola por sexo

\begin{tabular}{|l|c|}
\hline Sexo & Quantitativo \\
\hline Feminino & 10 \\
\hline Masculino & 03 \\
\hline Total & 13 \\
\hline \multicolumn{2}{|c|}{ Fonte: Dados da Pesquisa }
\end{tabular}

Tabela 11 - Profissionais da escola por categoria

\begin{tabular}{|l|c|}
\hline Categoria & Quantitativo \\
\hline Direção & 01 \\
\hline Coordenação & 01 \\
\hline Professores & 10 \\
\hline Terceirizado & 01 \\
\hline Total & 10 \\
\hline
\end{tabular}

Fonte: Dados da Pesquisa

Em relação aos participantes do "Projeto Estudar em Paz" foram realizadas 07 entrevistas entre participantes e ex-participantes, sendo 02 ex-participantes, 02 membros integrantes da coordenação executiva e 03 participantes bolsistas, sendo 06 do sexo feminino e 01 do sexo masculino, conforme Tabelas 12 e 13.

Tabela 12 - Participantes do projeto conforme o sexo

\begin{tabular}{|l|c|}
\hline \multicolumn{1}{|c|}{ Sexo } & Quantitativo \\
\hline Feminino & 06 \\
\hline Masculino & 01 \\
\hline Total & $\mathbf{0 7}$ \\
\hline
\end{tabular}

Fonte: Dados da Pesquisa

Tabela 13 - Participantes do projeto por categoria

\begin{tabular}{|l|c|}
\hline \multicolumn{1}{|c|}{ Categoria } & Quantitativo \\
\hline Estudante participante & 03 \\
\hline Estudante ex-participante & 02 \\
\hline Coordenação & 02 \\
\hline Total & $\mathbf{0 7}$ \\
\hline
\end{tabular}

Fonte: Dados da Pesquisa

Cabe esclarecer que considerei integrante do "Projeto Estudar em Paz" a pessoa responsável pelo desenvolvimento dele na escola pesquisada, apesar de ser também profissional da escola. O motivo para tanto se deu em virtude das atividades desenvolvidas pelo entrevistado junto ao "Projeto Estudar em Paz". Ademais, no ano de 2013 essa pessoa saiu da escola, mas permaneceu na execução do projeto, ministrando as aulas e como contato e referência dentre da instituição pesquisada. 
As dificuldades da realização das entrevistas foram as mesmas sentidas em relação ao grupo focal. Apesar de tanto a escola como os participantes do projeto terem se mostrado abertos e disponíveis para contribuir com a pesquisa, outras questões surgiram, tão ou mais complexas que a simples aceitação.

Em relação à escola pesquisada, não havia um espaço para realizar a escuta dos entrevistados, de forma que tudo ia acontecendo na copa, no pátio, na sala dos professores, num depósito e onde mais pudesse acontecer, desde que se mantivessem os critérios de sigilo e onde os entrevistados se sentissem à vontade.

É preciso lembrar também que, como se trata de uma escola, há barulho e entra-e-sai de pessoas praticamente em qualquer lugar e a toda hora. Além disso, a escola é um local de trabalho, de estudo e de atividades pré-programadas, com prazos previamente estabelecidos. Isso sem falar na disponibilidade temporal dos turnos de estudo e de trabalho. Mais uma vez, foi necessário compatibilizar a minha agenda com a da escola (e com todos os seus eventos e calendário) e com a dos entrevistados. Quanto aos participantes do projeto, os problemas foram os mesmos do grupo focal.

\subsubsection{Documentos}

Em relação aos documentos utilizados na construção dos dados da pesquisa, foram consideradas fontes primárias e secundárias, deliberadas ou não (BELL, 2004).

Como fontes primárias, foram utilizados os relatórios de atividades do "Projeto Estudar em Paz" dos anos de 2011 a 2013 entregues ao Decanato de Extensão (DEX) da UnB. Apesar de sua existência desde 2009, a transformação em PEAC deu-se apenas em 2010, de forma que a obrigatoriedade de apresentação de relatórios surgiu no ano seguinte. Os relatórios serviram como principal fonte para os dados secundários.

Contudo, é preciso esclarecer que o "Projeto Estudar em Paz" considera como produção própria, citando como "produção cultural", referências a ele em matérias jornalísticas ou presença em programas de televisão, assim como os vídeos do grupo, produzidos por ele mesmo, sobre mediação simulada bem como o blog ou a página no Facebook. Diante disso, também considerei esses documentos como sendo fonte relacionada à percepção que o projeto tem de si mesmo e não fiz a dissociação entre as reportagens sobre o projeto e pesquisas sobre ele, considerando todos como fontes de informação.

Nesse sentido, nem todos os produtos mencionados foram encontrados. Assim, por exemplo, no Relatório Final de 2012 há a menção de participação em um programa de 
rádio. Mesmo com pesquisas na Internet e mesmo junto ao grupo, solicitando mais informações sobre a fonte, não foi possível localizar essa reportagem.

Era também a intenção de utilizar nesta pesquisa fontes primárias como atas de reuniões, vídeos produzidos, informações contidas no blog e na página de uma rede social. No entanto, não foi possível o acesso a todas as atas de reuniões até o término do prazo para elaboração da dissertação. O blog também não se mostrou uma fonte de informações, tendo sido descartado. Os vídeos produzidos pelo grupo e disponibilizados em rede mundial de computadores constituíram-se em simulações de mediações. Nesse sentido, foram considerados os seus aspectos formais (tema, participantes e o assunto). Por fim, quanto à página do grupo em rede social, ela é restrita apenas aos membros do "Projeto Estudar em Paz" com o objetivo de circular informação sobre o desenvolvimento, as ações e as pautas de reuniões. Ela foi uma fonte de documentos, pois os temas tratados não contribuíram para o alcance dos objetivos dessa pesquisa.

Em relação às fontes secundárias, foram utilizadas três pesquisas, Furtado (2011), Gaspar (2012) e Carneiro (2014), bem como reportagens e artigos publicados sobre o "Projeto Estudar em Paz" e a escola pesquisada, todos mencionado nos relatórios ao Decanato de Extensão (DEX).

Quanto às informações sobre a escola pesquisada, à região administrativa e à comunidade circundante, foram utilizados o regimento interno e o projeto políticopedagógico, além de estudos e relatórios estatísticos.

As informações obtidas pela via documental serviram principalmente para a apresentação do "Projeto Estudar em Paz" e do campo.

\subsubsection{Observação e Notas de campo}

A observação na construção dos dados, conforme Bell (2004) e Gil (2012) é importante por revelar características impossíveis de serem descobertas por outros meios ao permitir a partilha das "experiências dos indivíduos que constituem o objeto de seu estudo e assim compreender melhor por que agiam esses desta ou daquela forma" (BELL, 2004, p. 25).

Considerando o objetivo específico de analisar os conflitos e as violências existentes no âmbito escolar retratados pelo "Projeto Estudar em Paz", a observação foi escolhida como uma forma exploratória de conhecer e apreender sobre sua realidade, seus conflitos e contradições, a fim de formular problemas e hipóteses mais precisos (GIL, 2012). Nesse sentido, ela foi realizada durante meu período como estagiária técnica junto ao NEP da 
UnB, no período de outubro de 2012 a abril de 2013, e como voluntária de abril a outubro de 2013, constituindo-se em observação participante (BELL, 2004).

Minhas atividades, no entanto, eram eminentemente administrativas. Isso significa que até o momento da escolha da escola pesquisada não tive acesso ao trabalho de campo, salvo nas atividades direcionadas a todo o grupo.

Já em campo, as observações e as notas centraram-se sobre minha percepção da escola, sua estrutura física e nas formas de resolução de conflito. As notas, nesse caso, foram utilizadas para ilustrar casos e exemplos apresentados no capítulo de análise dos dados.

\subsection{O tratamento dos dados}

Para o atendimento aos objetivos desta pesquisa, utilizou-se a Análise de Conteúdo (AC) por permitir a avaliação de um grande número de informações, sendo fácil a revisão de categorias e o refazimento do trabalho (HERSCOVITZ, 2005). Além disso, tanto Bauer (2003) quanto Herscovitz (2005) consideram que ela diminui a intromissão do pesquisador.

A AC é dividida em uma análise quantitativa e outra qualitativa. A parte quantitativa consiste na contagem de frequência do conteúdo manifesto (referente a situações, pessoas e lugares) por meio de estatística (HERSCOVITIZ, 2007. BAUER, 2003). Por sua vez, a base qualitativa, baseia-se na avaliação do conteúdo latente a partir do sentido geral do seu contexto (HERSCOVITIZ, 2007). Nesse ponto, ela reconstrói representações em duas dimensões principais. Na primeira, a sintática, há um foco nos transmissores de sinais e suas inter-relações, ou seja, como algo é dito, sua expressão ou influência. Na segunda, a semântica, os sentidos expressos, quem diz e para quem diz, são focados e confrontados com outras já existentes, a fim de se chegar às generalizações (GIL, 2012).

Tendo-se esses aspectos como parâmetros, principalmente quanto à busca por uma análise com menor interferência do pesquisador e com rápido retorno, optei também por fazer uso da ferramenta de apoio QSR N’Vivo® 10.0.

\subsubsection{O N’Vivo®}

O N’Vivo® é um dos mais famosos softwares de auxílio da pesquisa qualitativa (LAGE, 2011). Tanto Lage (2011) quanto Vicario, Garcia e Gomes (2013) mencionam a importância do uso dessa ferramenta no tratamento de grande número de dados e no auxílio de construção de gráficos, tabelas e relacionamentos de informações de forma a ganhar tempo na tabulação dos dados. 
Diante disso, após a finalização das entrevistas e do grupo focal, as transcrições foram editadas, retirando-se as perguntas e eventuais comentários dos responsáveis pela transcrição. Os textos foram, então, colocados em grupos: estudantes, profissionais da escola e participantes do projeto como "fontes” (materiais de pesquisa) do programa N'Vivo®.

Em seguida, foi feita uma leitura flutuante e, posteriormente, a codificação por temas em Nós (Tree Nodes) como "relações entre professores e alunos", "percepções sobre pais", "pontos positivos da escola", "sobre o curso de mediação", "expectativas sobre o projeto", "impactos do projeto", "sugestões”. Ao todo, foram 21 Nós independentes.

Os Nós foram, então, submetidos a uma contagem de frequência de palavras, considerando-se todas as palavras com extensão maior ou igual a 03 dígitos ou letras. A pesquisa foi feita por similaridade, de forma que palavras como "aluno" e "alunos" pudessem ser contabilizadas conjuntamente.

Após uma primeira contagem, as listas produzidas passaram por uma filtragem, sendo excluídas palavras sem valor interpretativo, mas com alta incidência, tais como "assim", "né", "tipo". Em seguida, foi realizada uma nova pesquisa de palavras. Com isso, foram consideradas 4.894 palavras cuja recorrência pode ser percebida pelo Gráfico 3, no qual as palavras maiores são as de maior incidência:

Gráfico 3 - Gráfico nuvem apresentando as palavras de maior incidência

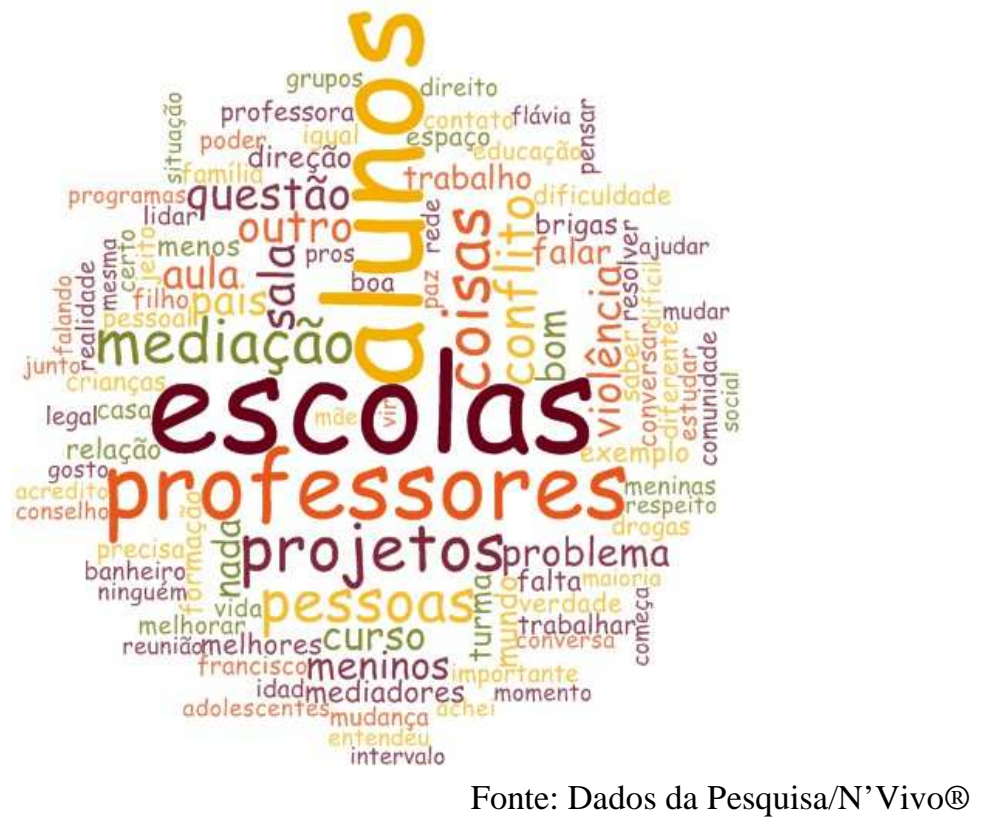

Após esses procedimentos foram consideradas as 15 palavras com maior recorrência, sua contagem total e o percentual ponderado e, por fim, as palavras similares, que integraram a pesquisa, conforme demonstra a Tabela 14: 
Tabela 14 - Contagem total de palavras

\begin{tabular}{|c|c|c|c|}
\hline Palavra & Contagem & Percentual Ponderado & Palavras Similares \\
\hline Escola & 954 & 2,07 & Escola, escolas \\
\hline Alunos & 939 & 2,06 & Aluno, alunos \\
\hline Professor & 611 & 1,34 & Professor, professore, professores \\
\hline Projeto & 393 & 0,86 & Projeto, projetos \\
\hline Coisas & 389 & 0,85 & Coisa, coisas \\
\hline Mediação & 345 & 0,76 & Mediação \\
\hline Pessoas & 339 & 0,74 & Pessoa, pessoas \\
\hline Conflito & 281 & 0,62 & Conflito, conflitos \\
\hline Sala & 243 & 0,53 & Sala, salas \\
\hline Outro & 223 & 0,49 & Qutro, outros \\
\hline Questão & 221 & 0,49 & Pai, pais \\
\hline Violência & 203 & 0,44 & Aula, aulas \\
\hline Pais & 199 & 0,44 & Cursos, cursos \\
\hline Aula & 191 & 0,42 & Violência, violências \\
\hline Curso & 184 & 0,40 & Dados da Pesquisa / N’Vivo \\
\hline
\end{tabular}

Foram escolhidas essas 15 palavras por se considerar que elas são representativas do contexto da pesquisa e englobarem as principais percepções do entrevistados sobre o "Projeto Estudar em Paz". Ademais, após uma leitura preliminar dos contextos, palavras com percentual ponderado menor que 0,40 mostraram estar dentro dos contextos das palavras acima indicadas. Esse conjunto final foi submetido à análise qualitativa, isto é, à busca dos contextos e do sentido geral, que serão apresentados no próximo capítulo.

A preocupação sobre tabulação dos dados e sua análise, bem como quais ferramentas utilizar, não foi o único ponto a ser considerado em todo o percurso da pesquisa. Houve outro, tão importante quanto, que permeou a construção deste trabalho desde os seus primeiros passos: a preocupação ética e política.

\subsection{Qualidade política e ética}

Uma das principais questões a se trabalhar numa pesquisa envolvendo a temática dos direitos humanos, como é o caso do presente trabalho, é como considerar os aspectos da dignidade de pessoa humana, de respeito aos sujeitos de direito envolvidos na pesquisa. Enfim, como ela pode ter qualidade política (DEMO, 1995).

Diante disso, o presente trabalho não poderia ser construído tendo por base apenas os aspectos formais. Daí ele buscar compreender a realidade social a partir de uma 
ótica crítica, realizadora de direitos humanos e de cidadania, e ainda se preocupar em atender aos aspectos éticos de uma pesquisa envolvendo seres humanos.

Dessa forma, o processo de obtenção de consentimento junto ao público alvo desta pesquisa, ou seja, estudantes, profissionais da escola, integrantes do "Projeto Estudar em Paz”, foi feito seguindo uma postura ética. Assim, desde o início todos os participantes do "Projeto Estudar em Paz" sabiam que se estava desenvolvendo uma pesquisa "sobre a história do projeto" e que buscava a colaboração deles para conhecer e construir essa história. Assim, todo o processo de construção deste estudo e de realização da observação prévia para delimitação do campo foram feitos junto a eles. Na realidade, fui convidada a auxiliar nos trabalhos do NEP justamente por ter o interesse em desenvolver tal pesquisa.

Ainda assim, após a delimitação dos aspectos metodológicos envolvidos, foi entregue carta de apresentação e de pedido de autorização para a coleta documental e para as entrevistas com os participantes, bem como houve informação oficial junto à página do grupo em rede social de computadores. Cabe esclarecer, ainda, que o convite geral para participação de entrevista e de grupo focal foi feito posteriormente, junto à rede.

Em relação à escola pesquisada, em setembro de 2013 iniciei o processo de obtenção de consentimento livre e esclarecido, por telefone, e-mail e me reunindo, ao final, com a pessoa responsável pela direção do estabelecimento, a fim de explicar a pesquisa e o que se pretendia realizar. Também foi explicado sobre o anonimato e o sigilo absoluto de fonte, bem como sobre a facultatividade de participação. Fui apresentada à coordenação da escola, que se colocou prontamente a minha disposição e, posteriormente, também aos demais profissionais. Houve apenas a exigência de apresentação da autorização formal da coordenação do "Projeto Estudar em Paz" sob a percepção de que se ele era o objeto central de meu estudo, a autorização deveria partir da coordenação dele.

No que se refere aos entrevistados, a fim de se manter o sigilo da fonte, houve apenas a identificação conforme os grupos já apresentados (profissionais da escola, participantes do projeto e estudante) e sexo. Em relatos em que apareceram originalmente o nome de pessoas, grupos ou localidades e que precisaram ser reproduzidos para melhor compreensão do caso, houve o uso de pseudônimos.

Quanto à identificação da escola, diante da necessidade de mantê-la em sigilo, não fiz a identificação completa de documentos das referências bibliográficas em alguns dos documentos que a mencionavam. Isso porque, por exemplo, a Pesquisa Distrital por Amostra de Domicílios 2013 - 2014 (PDAD) foi publicada por região administrativa, sendo o nome do 
relatório o próprio nome da região atendida. Mencioná-la de forma completa nas referências bibliográficas significaria identificar a RA e, em consequência, a própria escola atendida.

Mesmo com a autorização da instituição, cada um dos entrevistados passou por um procedimento de esclarecimento sobre a pesquisa e, após, de autorização de participação por meio de Termo de Consentimento Livre e Esclarecido (TCLE). Todos foram informados sobre sua participação ser facultativa e da necessidade de autorização de uso de suas informações em pesquisa. Também foi informado quanto ao direito de retirar tal autorização a qualquer momento durante a pesquisa, assim como sobre questões de sigilo.

Foi facultado aos entrevistados escolher a forma de registro das entrevistas, se em áudio ou escrito, de forma que seis (três estudantes e três profissionais na escola) não autorizaram a gravação. Nesse caso, as entrevistas foram escritas, com conhecimento do entrevistado. Tal faculdade não foi dada aos participantes do grupo focal em razão da dinâmica do trabalho, com várias pessoas conversando, o que exigiu a gravação. Diante disso, dois estudantes desistiram, após a explicação.

No que se refere aos estudantes, por serem maiores de 12 anos, não submeti sua participação ao consentimento de mães, pais ou responsáveis. Levei em consideração o teor da pesquisa, a ausência de riscos e os benefícios envolvidos, além do direito de decisão desses estudantes sobre questões que lhe dizem diretamente respeito.

Assim, considerei sua capacidade de formular seus próprios pontos de vista sobre os assuntos relacionados a eles, conforme expresso no art. 12 da Convenção sobre os Direitos da Criança (ONU, 1989), que garante à criança com capacidade de discernimento o direito de exprimir sua opinião sobre as questões que lhe digam respeito, da mesma forma como considerei, por analogia, os direitos de manifestação, de livre ação e de protagonismo que os adolescentes já possuem dentro do direito brasileiro.

Também foram levados em consideração trabalhos como o de Ferreira e Souza (2012), Jager et al (2013) e Velho, Quintana e Rossi (2014) sobre os aspectos éticos da pesquisa com adolescentes e a possibilidade de sua autonomia no consentimento para participar.

\subsection{Apresentando o campo}

\subsubsection{O "Projeto Estudar em Paz"}

O projeto-piloto que, mais tarde, deu origem ao "Projeto Estudar em Paz" teve início em 2009, no Centro Educacional (CED) São Francisco, "Chicão", escola pública de 
ensino dos últimos anos do ensino fundamental, ensino médio e de educação de jovens e adultos (EJA), em São Sebastião, Distrito Federal (FURTADO, 2011; BELEZA, 2012).

Tudo começou com uma oficina, em 16 de janeiro daquele ano, sobre mediação de conflitos para os alunos e alunas da escola, ministrada por mim e a atual coordenadora-executiva do "Projeto Estudar em Paz", Flávia Beleza. Tal oficina integrava as atividades do programa "Oficinas de Mídias e Cidadania", do Ministério da Justiça, cujo objetivo era "estimular a consciência cidadã dos jovens por meio do debate sobre temas como direitos humanos e meios de comunicação de massa" (BRASIL, 2009a).

Com a oficina, os alunos e as alunas ficaram empolgados com a proposta da mediação de conflitos diante de sua realidade, então percebida como permeada de situações de violência física principalmente entre estudantes. Assim, eles solicitaram um curso que aprofundasse a discussão, o que foi aceito e encampado pela então equipe gestora da escola. Dessa forma, foi a partir do protagonismo de estudantes do "Chicão" que se iniciou o curso de formação de alunos mediadores dentro da proposta da mediação social.

A primeira turma formou-se ao final de 2009 com 15 concludentes, após um curso de 100 horas/aulas. Desde então, a proposta já era de alcançar todos os segmentos da escola, formando um mediador capaz de identificar os problemas relacionados aos conflitos interpessoais, crítico de sua realidade e consciente de seu papel na transformação social.

Nesse primeiro ano, além da conclusão da primeira turma, instituiu-se o núcleo de mediação de conflitos, além de ter sido criado o primeiro blog - diário virtual - do grupo, com o objetivo de ser um espaço de diálogo e reflexão (ESTUDAR EM PAZ, 2009). Além disso, como conclusão do curso, foi realizado um vídeo, publicado na rede social Youtube, de uma mediação simulada como o objetivo de facilitar a formação de futuros mediadores e divulgar o então projeto piloto na "formatura" dos mediadores. Foi o primeiro vídeo de uma mediação simulada no contexto escolar em língua portuguesa (ESTUDAR EM PAZ, 2010).

A construção do roteiro deu-se de forma conjunta, a partir de um dos conflitos mais comuns na escola: uma briga entre duas amigas em razão da fofoca de que uma delas estaria "dando em cima" do namorado da outra.

No ano seguinte, já sem a minha participação, o "Projeto Estudar em Paz" tornou-se PEAC da UnB. A título de esclarecimento, nos termos do Decreto n. 7416, de 30 de dezembro de 2010, que regulamenta os artigos 10 e 12 da Lei no 12.155 , de 23 de dezembro de 2009, que tratam da concessão de bolsas para desenvolvimento de atividades de ensino e extensão universitária, projetos de extensão são ações formalizadas com objetivos específicos e prazos determinados, ainda que renováveis, que visam a resultados de mútuo interesse entre 
comunidade acadêmica e sociedade (BRASIL, 2010). Assim, já como PEAC, ele integrou a linha de "Direitos Humanos e Justiça", com a seguinte ementa:

O projeto tem como objetivo levar a cultura da mediação para o Centro Educacional São Francisco, em São Sebastião, por meio da formação de mediadores na escola (alunos, professores, corpo técnico-administrativo e pais) e da divulgação dos valores da Cultura de Paz, dos direitos humanos e de cidadania. Isto porque a mediação, mais que um método pacífico de solução de conflitos, é uma prática social capaz de restaurar os laços afetivos, familiares e sociais, bem como um instrumento de promoção da paz, da cidadania e dos direitos humanos. Nessa perspectiva, a mediação tem potencial para transformar não só as situações, mas também as pessoas e, por conseguinte, o conjunto da sociedade (UNB, 2010, p. 93).

A partir de então, o curso de formação passou a ser de 36 horas/aula, sendo ministrados os seguintes temas: "os conceitos de direitos humanos e o conceito de paz positiva; a mediação social no contexto escolar; conceito de conflito; tipos de violência; técnicas de mediação e aulas práticas" (FURTADO, 2011, p. 8). Nesse ano, foram formados 40 alunos e 30 professores como mediadores (CANNES, 2010).

Também foi em 2010 que teve início a divulgação do "Projeto Estudar em Paz" em âmbito nacional pela reportagem "Professores Resolvem conflitos no DF na base da conversa" no programa Fantástico, na Rede Globo de Televisão (CANELLAS, 2010), continuada por outras reportagens nas quais o projeto aparece como um promotor do diálogo e do respeito nas escolas (CANNES, 2010) bem como de uma proposta que transforma a "liderança negativa" de alguns ou algumas estudantes em uma liderança positiva, conforme expresso pelo Correio Braziliense (2011), no ano seguinte.

Tais reportagens fazem com que o "Projeto Estudar em Paz" passe por uma rápida expansão nos anos seguintes. Por outro lado, causam também certo mal estar entre seus participantes, à medida que percebem que ele é visto como uma ação que resolve tudo como um "passe de mágica". Essa percepção pode criar uma situação que limita o "Projeto Estudar em Paz" como uma ação que busca apenas um diálogo dentro da escola, com foco apenas na transformação dos alunos. Esse fato foi observado durante meu período de estágio técnico.

Daí que, ainda em 2011, por meio de uma reportagem do Programa Alternativo do SBT - Brasília sobre a formatura de uma das turmas de mediadores, com 16 alunos (CHAUVET, 2011) há a ênfase no discurso de que o "Projeto Estudar em Paz" não trabalha apenas a violência dentro da escola, entre alunos, mas principalmente a violência estrutural, relacionada às condições sociais. É então a primeira vez que esse tópico é ressaltado, assim como, mais uma vez, ressaltou-se a importância da formação de todos os grupos presentes na escola: alunos, professores, servidores, mães, membros da comunidade em geral. 
Nesse mesmo ano, o "Projeto Estudar em Paz", apesar de ainda ter como foco principal a atuação dentro de escolas, passa a ministrar o curso de mediação social a orientadores educacionais, buscando fomentar essa prática na parte administrativa da escola. À vista disso, ao final de 2011, além da atuação nas escolas atendidas, são realizados cursos e oficinas para diretores e orientadores educacionais em quatro regiões administrativas, totalizando 185 pessoas atendidas, além da participação em eventos vinculados à mediação de conflitos e à construção de uma cultura de paz. Por fim, outro blog foi criado, com o fim de se fazer o acompanhamento do projeto, referente a uma das escolas atendidas, na RA do Recanto das Emas, Distrito Federal (Relatório Final, 2011).

Em 2012 há a inclusão de novos vídeos na rede social Youtube sobre as experiências desenvolvidas no ano anterior. Assim, o vídeo "Projeto Estudar em Paz - vídeo 3" (2012) refere-se a um conflito relacionado à inclusão de um estudante cadeirante e com outras necessidades especiais e sua dificuldade de relacionamento com os demais estudantes.

Já o "Projeto Estudar em Paz - vídeo 4" (2012a) apresenta uma simulação de mediação entre estudantes "de diversas tribos" em razão de dificuldades de convivência no espaço escolar" nos quais os "diferentes" são vítimas de "brincadeiras" por parte dos outros estudantes (Relatório do Coordenador, 2011).

O vídeo "Projeto Estudar em Paz - vídeo 5" (2012b), por sua vez, apresenta o núcleo de mediação de uma das escolas atendidas, o processo de mediação formal e algumas de suas técnicas, justificando a existência de um mobiliário específico, a forma de tratamento e apresentando as fases do processo conforme o "Projeto Estudar em Paz" o concebeu.

Mais uma vez, a mediação é colocada como forma de transformar o conflito, as pessoas, a situação, melhorando as relações sociais, o mesmo ocorrendo no sexto vídeo, “A arte da mediação" em que ela é vista como "prática social de transformação" (2012c) e de reflexão da realidade e do conflito. Nesse vídeo, alunos e empregados da escola, do serviço de limpeza e segurança, falam sobre sua percepção sobre a mediação.

Ainda em 2012, o "Projeto Estudar em Paz" desenvolveu suas atividades em quatro escolas, de RAs diferentes, além da formação dos orientadores educacionais das regionais de ensino do Gama e de Samambaia, no Distrito Federal (BELEZA, 2012). O trabalho então desenvolvido era dividido em grupos de estudo e de trabalho:

[...] um Grupo de Estudos do Estudar em Paz (para discentes bolsistas da Universidade de Brasília), um Grupo de Estudos em Mediação Social (para discentes da Universidade de Brasília e da Universidade Católica) e um Grupo de Trabalho do Estudar em Paz (para supervisão e orientação aos profissionais da educação formados pelo projeto que pretendem difundi-lo) (BELEZA, 2012, p.53). 
Tal divisão tornou-se possível em razão de uma parceria com o projeto de extensão da Universidade Católica de Brasília - UCB, "Sankofa - Identidades e Direitos Humanos nas Escolas" (FLÁVIA, 2012). Contudo, tal parceria encerrou-se no final de 2012.

Paralelamente a isso, o discurso presente nas reportagens veiculadas, sem desconsiderar os aspectos do diálogo e da convivência, enfatizam cada vez mais as questões sociais nas quais a escola está inserida (CHAUVET, 2012). Já Lacerda (2012) refere-se à atuação do "Projeto Estudar em Paz" na identificação dos problemas na escola e na articulação dessa instituição com aquelas que prestam serviço de apoio, como os centros de assistência psicossocial e os conselhos tutelares. A ideia presente, então, é que a escola não tem como identificar e trabalhar esse tipo de conflito que, contudo, impacta sua atuação, e que só pode ser tratado por meio de uma ação coletiva, de um reforço ao sentido de comunidade (LACERDA, 2012). É então que o "Projeto Estudar em Paz" apresenta-se como elo para a reparação de laços sociais e como formador de um sujeito coletivo (LACERDA, 2012), ideia também presente em Beleza:

Diante da exacerbação da violência social que atinge profundamente a escola, percebe-se o hiato existente entre a escola e a comunidade, especialmente com a sua rede social local. Por isso, uma das principais ações do projeto é tecer a rede de proteção social entre a escola, a família e a comunidade e promover os direitos de cidadania. Aproximar populações excluídas dos serviços públicos é um papel fundamental da mediação social (BELEZA, 2012, p. 56).

Diante disso, os objetivos do "Projeto Estudar em Paz" são assim descritos:

O projeto tem como objetivo geral capacitar estudantes (inclusive os(as) bolsistas e estagiários(as) da graduação), professores(as), corpo técnico-administrativo e pais/mães (e/ou responsáveis) de alunos(as) em mediação de conflitos no contexto escolar, na perspectiva da mediação social, visando a consolidar uma compreensão da mediação de conflitos como instrumento para uma prática cidadã junto às escolas da rede pública do Distrito Federal.

Os objetivos específicos do projeto são: possibilitar a leitura de textos sobre mediação social, conflitos e violências no contexto escolar e processos de emancipação e subjetivação, de modo a estimular o pensamento crítico acerca desses temas; fomentar junto à comunidade escolar práticas socioeducativas pautadas na Cultura de Paz, direitos humanos, justiça, democracia e cidadania; incentivar junto aos diferentes segmentos sociais a incorporação da prática da mediação como instrumento de diálogo, participação e de transformação pessoal e social; supervisionar e acompanhar os(as) alunos(as) formados(as) em mediação social nas atividades teóricas e práticas a serem desenvolvidas junto aos(às) novos(as) participantes inscritos(as) no projeto; difundir a experiência da mediação no contexto escolar junto à rede de ensino do Distrito Federal (BELEZA, 2012, p. 56).

A proposta apresentada, assim, é a do enfoque global, no qual o "Projeto Estudar em Paz" se propõe a influenciar o sistema disciplinar da escola, seu currículo, sua pedagogia, sua cultura escolar, o lar e a comunidade, além de outros dois pontos:

O espaço físico da escola - é necessário cuidar do espaço físico da escola para que seja um espaço acolhedor, bonito, criativo, acessível, seguro e limpo. Além do 
ambiente interno, merecem atenção aspectos externos, como ruídos, calçadas, iluminação etc. Educação se faz na alegria e na democracia.

As instituições públicas locais - tecer a rede social de apoio entre a escola, a família e a comunidade, especialmente no que diz respeito aos serviços públicos essenciais, melhorando a relação usuário/instituição. $\mathrm{O}$ entendimento é que a escola não pode mais prescindir do apoio desses serviços e de seus profissionais, uma vez que os conflitos e violências no contexto escolar só podem ser enfrentados coletivamente, com o apoio de outras instituições do Estado (BELEZA, 2012, p. 57).

Para alcançar essas metas e objetivos, a implantação do "Projeto Estudar em Paz" ocorre em doze passos, que englobam desde sua apresentação na escola a ser atendida até a avaliação e divulgação de resultados. Para apresentar de forma mais didática neste trabalho, sintetizei essas etapas, a partir de Beleza (2012) nas seguintes fases: conhecimento, cursos de mediação, instituição do núcleo e sensibilização.

A fase de conhecimento corresponde aos passos de 1 a 5 expressos por Beleza (2012). Refere-se ao reconhecimento entre escola e a comunidade atendida e o próprio "Projeto Estudar em Paz". Nela, busca-se "contextualizar os conflitos, fazer diagnóstico, mapear a rede social pública e privada; identificar necessidades e recursos" (BELEZA, 2012 p. 57). É ainda o momento de sensibilização de todos os estratos por meio de palestras, oficinas entre outras ações e do início de uma campanha de transformação do espaço físico da escola. Cabe ressaltar que nessa fase deve ocorrer o mapeamento da rede, mas não há referências a ele, salvo em nota de rodapé em Beleza (2012, p. 57):

\footnotetext{
O projeto tem como importante objetivo mapear a rede de solidariedade local e os serviços públicos disponíveis para criar ou melhorar a relação entre a escola e estas instituições. $\mathrm{Na}$ implementação do projeto em algumas escolas, percebe-se que os encaminhamentos (dos alunos para outros serviços públicos) são feitos de forma equivocada e esporádica. A alegação é de que é grande a ineficiência desses serviços (não atendem a demanda), mas muitos desconhecem suas funções. Algumas das instituições mapeadas são: Cras (Centro de Referência de Assistência Social); Caps (Centro de Referência Psicossocial); Conselho Tutelar e a rede de solidariedade local (instituições civis e religiosas).
}

Nos relatórios ao DEX de 2011 e 2012, contudo, o mapeamento da rede é colocado como dificuldade a ser enfrentada:

No decorrer do trabalho, percebeu-se o divórcio que existe entre a escola e a
comunidade, principalmente com a sua rede social local. Uma das ações do projeto é
tecer a rede entre a escola, a família e a comunidade e promover os direitos de
cidadania. Nesse sentido, os alunos bolsistas estão fazendo um mapeamento da rede
social de proteção das três cidades do projeto [...] para melhorar o apoio às escolas.
A maior dificuldade tem sido obter as informações necessárias das instituições
públicas (Conselho Tutelar, Centro de Referência de Assistência Social-CRAS,
Centro de Atenção Psicossocial- CAPS e outras), diante da precariedade dos
registros, de recursos e de pessoal (Relatório Final do Coordenador, 2011, p. 6)

Cabe mencionar que, ademais, até o final da fase de construção de dados da presente pesquisa, não foram encontradas referências sobre esse mapeamento. 
A fase seguinte refere-se aos cursos de formação e à instituição de um núcleo de mediação. Conforme Beleza (2012) e Chauvet (2011 e 2012) os cursos seriam abertos e facultativos a qualquer interessado. Mais uma vez, tal curso apresenta-se como direcionado a toda a comunidade escolar, englobando uma carga horária de 12 a 40 horas/aula. Em relação ao núcleo de mediação, seria um espaço da própria escola, conforme Beleza (2012), neutro e estruturado, ambientando e gerido pelos mediadores, em especial estudantes.

A última fase, chamada de sensibilização, refere-se às etapas 8 a 12 previstas ainda em Beleza (2012), direcionadas às ações de manutenção: formatura, sensibilização permanente, supervisão de atendimento das medições, avaliação e divulgação.

Com o atendimento a todas essas etapas, os resultados esperados são:

[...] melhoria das relações sociais na escola e na comunidade e das relações familiares nos lares dos(as) participantes do projeto; maior participação dos(as) mediadores(as) (todos os segmentos) na gestão democrática da escola; abertura de canais de diálogo e participação na escola e na comunidade; melhor compreensão dos valores da mediação social, cultura de paz, direitos humanos, justiça e cidadania; diminuição da violência na escola, na comunidade circunvizinha e nos lares $\operatorname{dos}($ as) atendidos(as) pelo projeto; multiplicação do projeto por meio da capacitação contínua de novos(as) mediadores(as) nas escolas pelos(as) mediadores(as) já capacitados(as); sustentabilidade do projeto (BELEZA, 2012, p. $57)$.

Não são todas as escolas que podem ser atendidas pelo "Projeto Estudar em Paz”. Os requisitos de inclusão relacionam-se à existência de conflitos e violências, vulnerabilidade social e compromisso da escola com as mudanças pretendidas (BELEZA, 2012), de forma que, o final de 2013, a situação do "Projeto Estudar em Paz", em relação às escolas atendidas era a seguinte:

Tabela 15 - Situação do projeto ao final de $2013 \mathrm{em}$ relação às escolas atendidas

\begin{tabular}{|c|c|c|c|c|}
\hline Escolas & Tipo de Escola & $\begin{array}{l}N^{\circ} \text { aluno } \\
2013\end{array}$ & Início & Término \\
\hline$\overline{\mathbf{A}}$ & 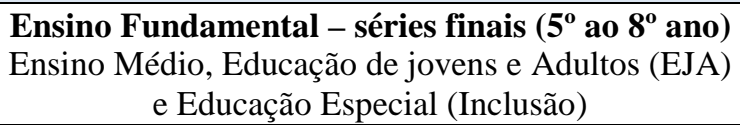 & 1.811 & 2009 & 2012 \\
\hline B & $\begin{array}{l}\text { Ensino Fundamental - séries finais ( } 5^{\circ} \text { ao } 9^{\circ} \\
\text { ano), Educação de Jovens e Adultos (EJA) e } \\
\text { Educação Especial (Inclusão) }\end{array}$ & 1.690 & 2010 & 2012 \\
\hline $\mathbf{C}$ & $\begin{array}{c}\text { Ensino Fundamental - }\left(1^{\circ} \text { ao } 9^{\circ} \text { ano) e Educação }\right. \\
\text { Especial (classe especial e inclusão) }\end{array}$ & 1.171 & 2011 & 2013 \\
\hline D & $\begin{array}{l}\text { Ensino Fundamental - séries finais ( } 5^{\circ} \text { ao } 9^{\circ} \\
\text { ano), Educação de Jovens e Adultos (EJA) e } \\
\text { Educação Especial (Inclusão). }\end{array}$ & 1.696 & 2012 & 2013 \\
\hline $\mathbf{E}$ & $\begin{array}{c}\text { Educação Infantil (Pré-Escola), Ensino } \\
\text { Fundamental (10 ao } 5^{\circ} \text { ano), Educação Especial } \\
\text { (classe especial e inclusão) }\end{array}$ & 523 & 2012 & - \\
\hline
\end{tabular}

Fonte: Beleza (2012) / Estudar em Paz (2014) / Distrito Federal (2013) / QEDu (2013)

Em relação à avaliação sobre o alcance de metas e objetivos, foram 
encontrados três trabalhos acadêmicos: duas monografias de conclusão do curso de serviço social da UnB (FURTADO, 2011. CARNEIRO, 2014) e uma dissertação de mestrado em educação pela Universidade Católica de Brasília (UCB) (GASPAR, 2012).

Furtado (2011), a partir da perspectiva da educação em direitos humanos, analisou as representações sociais de estudantes e professores dos anos finais do ensino fundamental e do ensino médio acerca das violências existentes na escola e a experiência da mediação de conflitos pelo "Projeto Estudar em Paz". Para tanto, utilizou a Análise de Conteúdo (AC). Os estudantes selecionados para responder à entrevista semiestruturada possuíam problemas disciplinares e desempenhavam a função de mediadores discentes.

Assim, os conflitos identificados foram principalmente discussões e brigas, sendo os mais comuns, na escola pesquisada, os relacionados a namoros entre estudantes, além de brigas entre alunos e professores e entre alunos. Em relação às violências da escola, as mencionadas foram os xingamentos e as ameaças pessoais, sendo as principais, na escola pesquisada, a agressão física, as humilhações e os xingamentos seguidos pelas ameaças pessoais e homofobia. As Tabelas 16 e 17, construídas a partir das conclusões de Furtado (2011) apresentam os principais conflitos e violências da escola pesquisada:

\begin{tabular}{|l|r|}
\hline \multicolumn{2}{|c|}{ Tabela 16 - Conflitos mais comuns } \\
\hline \multicolumn{1}{|c|}{ Respostas } & Respondentes \\
\hline Questões de namoro & 8 \\
\hline Briga entre aluno e professor & 3 \\
\hline Brigas entre alunos & 3 \\
\hline Razões familiares & 2 \\
\hline Bullying & 2 \\
\hline Violência verbal & 2 \\
\hline Preconceito & 1 \\
\hline Desrespeito & 1 \\
\hline Motivos pessoais & 1 \\
\hline Conflitos com vizinhos & 1 \\
\hline
\end{tabular}

\begin{tabular}{|l|r|}
\hline \multicolumn{2}{|c|}{ Tabela 17 - Violências mais comuns } \\
\hline \multicolumn{1}{|c|}{ Respostas } & Respondentes \\
\hline Humilhação / xingamento & 14 \\
\hline Agressão física & 14 \\
\hline Homofobia & 11 \\
\hline Ameaças pessoas & 7 \\
\hline Roubo & 3 \\
\hline Brincadeira de mau gosto & 11 \\
\hline
\end{tabular}

Fonte: Furtado (2011)

A experiência em mediação vem para lidar com essas situações. Assim, a percepção dos entrevistados sobre a mediação é, conforme Tabela 18, a seguinte:

\begin{tabular}{|l|r|}
\hline \multicolumn{2}{|c|}{ Tabela 18 - Representação social em mediação } \\
\hline Respostas & \multicolumn{1}{c|}{ Respondentes } \\
\hline Forma de ampliar o diálogo & 3 \\
\hline Oportunidade de compreender a si a aos outros & 3 \\
\hline Ocorrência de mudança & 3 \\
\hline Oportunidade de reconhecer erro & 2 \\
\hline Aprendizado para lidar com conflito & 2 \\
\hline Respostas & Respondentes \\
\hline Maneira de viver melhor & 1 \\
\hline Melhor método & 1 \\
\hline \multicolumn{2}{|c|}{ Fonte: Furtado (2011) }
\end{tabular}


Já o aprendizado proporcionado pelo curso de mediação de conflitos seria:

\begin{tabular}{|l|c|}
\hline \multicolumn{2}{|c|}{ Tabela 19 - Aprendizado por meio do curso } \\
\hline \multicolumn{1}{|c|}{ Respostas } & Respondentes \\
\hline Aprender a ouvir & 5 \\
\hline Conversar ao invés de brigar & 5 \\
\hline Respeito & 3 \\
\hline Professor aprender a lidar melhor com aluno & 2 \\
\hline Exercício da paciência & 2 \\
\hline Diminuição das brigas na escola & 2 \\
\hline
\end{tabular}

Furtado (2011) também verificou que $85 \%$ dos entrevistados consideraram que a prática da mediação de conflitos teria diminuído os conflitos e as violências na escola, cabendo como sugestões de melhoria para o "Projeto Estudar em Paz":

\begin{tabular}{|l|c|}
\hline \multicolumn{2}{|c|}{ Tabela 20 - Sugestões } \\
\hline Respostas & Respondentes \\
\hline Divulgar mais o projeto dentro da escola & 8 \\
\hline Discutir o projeto dentro de sala de aula & 2 \\
\hline Fazer palestras sobre mediação & 2 \\
\hline Aumentar o número de mediadores no curso de formação & 1 \\
\hline Projetar vídeos e filmes sobre violência na escola & 2 \\
\hline Divulgar nas redes sociais & 1 \\
\hline Realizar festa para divulgar & 1 \\
\hline \multicolumn{2}{|c|}{ Fonte: Furtado (2011) } \\
\hline
\end{tabular}

Furtado (2011) concluiu, então, que o "Projeto Estudar em Paz" contribui para fortalecer as relações sociais e diminuir a violência na escola pesquisada.

Outra pesquisa realizada sobre o "Projeto Estudar em Paz" é de Gaspar (2012), para o mestrado em Educação da UCB, por meio de 14 entrevistas semiestruturadas, também submetidas à AC. Os objetivos das entrevistas foram verificar concepções, causas e conflitos no âmbito escolar; a compreensão acerca dos conceitos, funções e contribuições da mediação na escola; os princípios e as competências dos mediadores e os processos "identitários de formação docente relacionada à mediação de conflitos" (GASPAR, 2012, p. 70).

A autora considerou que a concepção de conflito prevalente era a de divergência de interesses e que a forma de enfrentamento é que o definiria como negativo ou positivo. Assim, a mediação de conflitos contribuiria na formação para a cidadania ao ser um processo participativo e fomentador da autonomia na resolução dos conflitos. Nesse sentido, ele teria o condão de permitir o diálogo sobre um fato conflituoso e, com isso, a construção de estratégias de contorno. A partir disso é que ele seria uma ação de controle e de resolução de conflitos, agindo, consequentemente, na prevenção da violência (GASPAR, 2012).

O processo de diálogo promovido pela mediação desmistificaria fatos e 
permitiria a discussão de temas como racismo, homofobia e exclusão, o que favoreceria a conscientização bem como recriação ou restabelecimento de laços de amizade (GASPAR, 2012). No entanto, em relação aos professores, Gaspar (2012) considerou que eles teriam resistências ao projeto, só o considerando após perceber o resultado positivo nas alunas e nos alunos. Por outro lado, haveria a constatação de uma deficiência na formação do professor para lidar com os conflitos em sala de aula.

Em suma, em relação a suas conclusões, Gaspar (2012) considera que o "Projeto Estudar em Paz" permite uma melhor interação entre as pessoas, que vai além dos muros da escola. O comportamento dos alunos e das alunas investigadas teria passado por uma alteração positiva, com "projeção de liderança" (GASPAR, 2012, p. 114), reflexão sobre os próprios atos, identificação do conflito de fundo, aumento da auto-estima e maior segurança para tomar suas próprias decisões:

Ao desenvolver e realizar ações assertivas por meio das competências desenvolvidas no projeto, os atores educacionais se fizeram líderes positivos. A cortesia, a liberdade para conversar, para expor seus problemas são aspectos percebidos na transformação dos alunos após participarem do curso de mediação. A tolerância e a iniciativa para evitar atos de violência também foram citadas como habilidades demonstradas pelos participantes da estratégia (GASPAR, 2012, p. 115).

O mais recente dos trabalhos, Carneiro (2014), teve como objetivo compreender como o "Projeto Estudar em Paz" contribui para o reconhecimento do conflito e o enfrentamento à violência no contexto escolar. Para tanto, fez uma análise documental que permitisse um estudo comparativo entre as realidades e os impactos do "Projeto Estudar em Paz” em duas escolas do Distrito Federal, uma no Gama e outra em São Sebastião.

A diferença essencial da experiência no Gama é que o projeto se une a uma experiência preexistente, a proposta "Mediação de Conflito: do Diálogo à Cidadania" efetivada pela orientadora educacional da escola atendida, estendendo-se a estudantes de 4 a 10 anos de idade, diferente do "Projeto Estudar em Paz" que priorizava, até então, os anos finais do ensino fundamental e ensino médio. Outro diferencial foi o uso prioritário das mediações coletivas. Apesar disso, as demais características foram mantidas, apenas adaptando-se o material pedagógico. Conforme Carneiro (2014, p. 58) os alunos:

[...] demonstram que o projeto tem contribuído para o fortalecimento e a criação dos laços sociais. Os estudantes dizem que aprenderam com a mediação a repeitar as pessoas, não brigar sem motivo, não gritar ao conversar, dar bom exemplo, pensar e refletir para resolver os conflitos, respeitar o espaço do outro, viver em comunidade, que o bullying é ruim, que é muito bom ser amigo, que não vale a pena bater e colocar apelidos nos colegas, que se deve manter o banheiro e a escola limpa, que não se deve xingar, aprenderam, ainda, a fazer mediação, dar aula de mediação, não ter preconceitos, que agir com violência não resolve nada e que a mediação abre as portas para a paz. Essa foi uma paráfrase dos relatos das crianças encontrados no relatório avaliativo. Como principal aprendizado citado, teve-se o respeito ao 
próximo e a compreensão de violência dura (agressões físicas e verbais - bullying).

As conclusões de Carneiro (2014, p. 62) são de que "não se pode afirmar se o projeto tem contribuído para a diminuição das violências na escola". Mas que ele tem favorecido a mobilização de alunos no enfrentamento à violência estrutural, colaborando para a transformação social. A autora também reitera que o objetivo do projeto é a transformação da realidade, o que o inclui dentro de um contexto de amplo espectro.

Entre as dificuldades encontradas na efetivação do "Projeto Estudar em Paz" constam a dificuldade de realização do curso dos professores. Ainda assim, tais profissionais teriam uma avaliação positiva desse projeto (CARNEIRO, 2014, p. 62-63).

Nesse sentido, o trabalho de Carneiro (2014) corrobora tanto o trabalho de Furtado (2011) quanto de Gaspar (2012). No entanto, o trabalho mais recente traz um diferencial em sua análise: o destaque para as mediações coletivas.

As mediações coletivas foram uma adaptação surgida diante da impossibilidade de criação de um núcleo de mediação dentro da escola. Diante disso, todos os conflitos, inclusive os inicialmente interpessoais, passaram a ser tratados de forma coletiva, salvo os casos de violência grave ou os que envolvessem fatos íntimos.

A escola atendida já possuía o costume de realizar assembleias, nas quais estudantes se reuniam para, de forma espontânea, dizer o que gostam ou não na escola. Nas mediações coletivas, por sua vez, os mediadores possuíam uma formação específica para "enxergar conflitos e violências", facilitar o diálogo e levar à reflexão "sobre a realidade da escola e da sua comunidade" e as reuniões possuíam pautas específicas, construídas pelos próprios estudantes, a fim de permitir que pessoas e instituições pudessem ser mobilizadas para participar. Algumas das pautas discutidas foram: a qualidade do lanche, a situação do ônibus escolar, o emprego de apelidos, a sujeira do banheiro e o valor do lanche na “vendinha" (CARNEIRO, 2014, p. 63).

Isso se dá porque "por meio das mediações coletivas os alunos aprenderam a se expressar melhor e a lutar pelos seus direitos de forma pacífica por meio do diálogo" (CARNEIRO, 2014, p. 67) e que, por trás dos conflitos trazidos pelos estudantes, haveria sempre a violência estrutural, reflexos da desigualdade social.

Assim é que o "Projeto Estudar em Paz" da UnB se propõe a ser uma ação de promoção do diálogo no âmbito escolar, com foco na transformação social, que desde 2009 desenvolve ações prioritariamente em escolas públicas do Distrito Federal localizadas em áreas de vulnerabilidade social. No recorte temporal deste trabalho, foi escolhida uma dessas escolas, sobre a qual se discorrerá a seguir. 


\subsubsection{A cidade e a comunidade}

A escola pesquisada localiza-se em uma das Regiões Administrativas (RA) do Distrito Federal, estando entre as dez com menor renda per capita mensal, com renda média mensal por domicílio de $72 \%$ da população entre um e cinco salários mínimos (DISTRITO FEDERAL, 2010. DIEESE, 2013). Ela também é uma das RA com menor Índice de Desenvolvimento (IDH) do Distrito Federal, sendo região de vulnerabilidade social (DIEESE, 2010).

Vulnerabilidade social é uma condição de desvantagem social relacionada à “disponibilidade dos recursos materiais ou simbólicos dos atores, sejam eles indivíduos ou grupos, e o acesso à estrutura de oportunidades sociais, econômicas, culturais que provêem do Estado, do mercado e da sociedade" (ABRAMOVAY et al., 2002 p. 29). Ao ser transformada em índice pelo Dieese (2010, p. 09), relaciona-se ao "contexto familiar, mediante 9 combinações excludentes de atributos relativos, principalmente, à renda per capita, tamanho, tipo, chefia e composição da família" conforme indica a Imagem 1:

Imagem 1 - Classificação de famílias por grupos de vulnerabilidade social

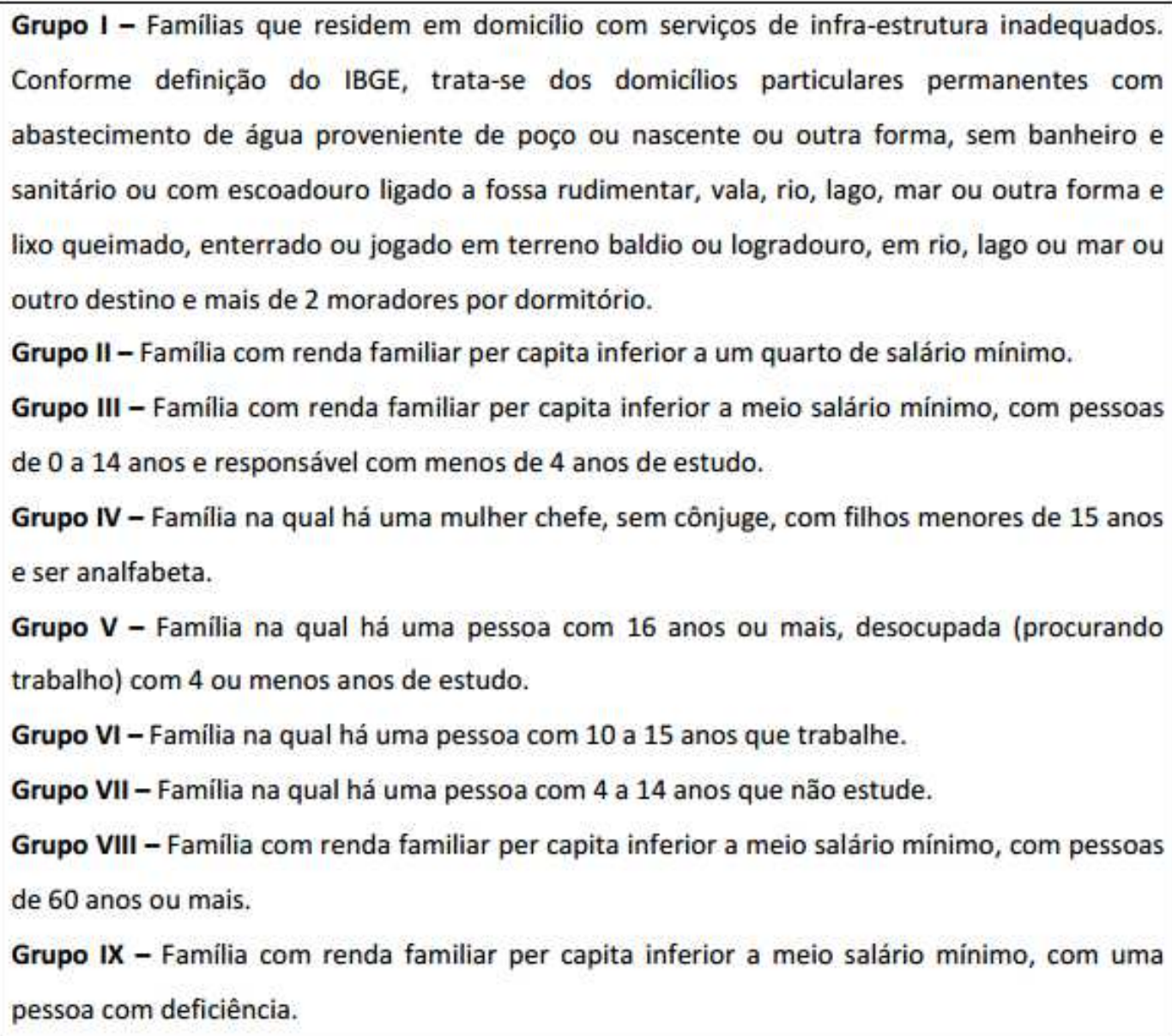


Dentro desse contexto, a região onde se localiza a escola pesquisada tem predominância do Grupo IV, com mais de $30 \%^{8}$ das famílias chefiadas por mulheres sem cônjuge, analfabetas e com filhos menores de 15 anos. Além desse grupo, também estão presentes o Grupo VII e o Grupo II, respectivamente (DIEESE, 2010). A vulnerabilidade social também pode ser percebida no percentual da população que recebe algum benefício social: 15\%, sendo que quase 13\% recebem o Bolsa-Família (DISTRITO FEDERAL, 2013).

A população é formada principalmente por mulheres (51\%) e jovens, com predominância da faixa etária de 6 a 15 anos (18\%), sendo que a faixa de 0 a 14 anos corresponde a quase $24 \%$. Cabe esclarecer que, em relação à cor da população, o Dieese (2010) informa uma predominância de negros (66\%), ao passo que a Distrito Federal (2013) informa serem mais de $60 \%$ os pardos, seguidos dos brancos (32\%) e negros (7\%).

Não foi possível apresentar uma conclusão definitiva quanto ao motivo dessa diferença, visto que ambas as metodologias seguem o padrão de declaração dos participantes e serem pesquisas por amostras de domicílios. Contudo, a Codeplan (DISTRITO FEDERAL, 2013), ao tratar da cor dos responsáveis economicamente pelos domicílios, considera a classificação de pardos como englobando pardos e mulatos, chegando, nesse ponto, a $60 \%$ dos domicílios. Nesse sentido, ela se aproxima do percentual do Dieese (2010), o que sugere que a diferença se dê na relação entre pardos-mulatos e negros-pretos. Em nenhuma das pesquisas há menção quanto a isso.

Conforme a PDAD 2013-2014 (DISTRITO FEDERAL, 2013) a maior parte da população é solteira (44\%), sendo que mais de $43 \%$ são filhos e mais de $26 \%$ são os responsáveis pelo domicílio.

Mais de $50 \%$ da população não frequenta a escola, mas sabe ler e escrever, sendo que quase $40 \%$ concluíram o ensino fundamental. A frequência à escola existe para um percentual entre 32 e $34 \%$ da população, mas ainda há mais de $15 \%$ de analfabetos e apenas $3 \%$ entre os que ao menos concluíram o ensino superior.

Entre os que estudam, a maioria frequenta a escola pública (26\%) e mais de $77 \%$ na própria região. Do total da população, $97 \%$ não participam de nenhuma atividade extracurricular, como curso de idiomas (DIEESE, 2010 e DISTRITO FEDERAL, 2013), o que traz um questionamento sobre que atividades seriam executadas ou desenvolvidas pelos estudantes no contra turno escolar, considerando as escolas não atuarem em tempo integral.

\footnotetext{
${ }^{8}$ Esse número é uma aproximação e não condiz com o número exato do Dieese (2010) a fim de dificultar a identificação da RA e, com isso, da escola pesquisada, conforme expresso no item 3.3. Qualidade política e ética do presente trabalho. Todos os percentuais apresentados nesta pesquisa seguirão esse padrão.
} 
Em relação ao crescimento populacional, a taxa anual é acima da média do Distrito Federal em mais de 1\%, resultado principalmente de migração interna, isto é, precedente de outras RA's, sendo que mais de $52 \%$ da população é nascida no próprio Distrito Federal. Em $2^{\circ}$ lugar, com $32 \%$ aparecem migrantes vindos da Região Nordeste do Brasil para acompanhar parentes (53\%), o que se justifica por serem filhos que chegaram na companhia dos pais (visto que 32\% vieram para procurar trabalho - DISTRITO FEDERAL, 2013).

Apesar disso, 32\% de sua população nunca se mudou da RA e quase $64 \%$ residem no local há mais de 10 anos, sendo 53\% na mesma casa (DISTRITO FEDERAL, 2013), o que se relaciona com as características das construções de moradia.

Nesse caso, a quase totalidade (97\%) são casas, permanentes, de alvenaria, cobertas de telhas de fibrocimento/amianto ou laje (76\%) e com piso de cerâmica (80\%), em terreno regularizado (90\%). São imóveis próprios (70\%) e já quitados em mais de $60 \%$ dos casos (DIEESE, 2010 e DISTRITO FEDERAL, 2013). Apesar disso, apenas 43\% possuem escritura definitiva (DISTRITO FEDERAL, 2013).

As casas são em sua maioria de pavimento único, com cinco a oito cômodos (66\%), entre 40 e $90 \mathrm{~m}^{2}$, com sala, dois quartos ou mais (80\%), com ao menos um banheiro interno (68\%), sendo que $32 \%$ possuem dois ou mais e acesso praticamente integral (mais de 95\%) à energia elétrica, água encanada e sistema coletor pluvial e de esgotamento sanitário, o que envolve tanto a rede geral pública (94\%), quanto as fossas sépticas (5\%). Apesar disso, mais de $20 \%$ das residências sofre com o problema de acúmulo de entulho, denotando o déficit na coleta de lixo (DISTRITO FEDERAL, 2013).

A região possui ainda posto ou centro de saúde, Centro de Referência de Assistência Social (CRAS), creche e escolas públicas nas proximidades, ou seja, com pelo menos $30 \%$ dos domicílios distantes a menos de 45 minutos a pé de cada um desses serviços sociais (DIEESE, 2010). Não há hospital.

A despeito da existência de creche, mais de $35 \%$ das crianças, na ausência de seus responsáveis legais, fica sob os cuidados de familiares, amigos, parentes ou conhecidos, na própria casa (DIEESE, 2010).

No aspecto econômico, o desemprego atingia, em 2010, 5\% da população economicamente ativa (PEA), sendo que mais da metade da população em idade ativa (PIA) estava ocupada em 2010, o que se manteve em 2013, e mais de $60 \%$ com carteira assinada.

Contudo, mais de $44 \%$ da população é inativa (PEI), conforme o DIEESE (2010), isto é, não está ocupada com um trabalho remunerado nem busca empregos. Nessa categoria encaixam-se pessoas com menos de 15 anos, estudantes que não trabalham, donas 
de casa que exercem apenas funções não remuneradas, pessoas que desistiram de procurar emprego há mais de um mês e aposentados acima de 65 anos que também não trabalham.

A maior fonte de renda dos trabalhadores da RA se origina do setor de serviços, com carteira assinada (DIEESE, 2010). Apesar disso, o Anuário do DF (2013) e a PDAD (DISTRITO FEDERAL, 2013) mencionam que a principal fonte econômica é o comércio, exercido principalmente em Brasília por mais de 33\% dos trabalhadores e, em seguida, na própria cidade, por mais de $26 \%$. Em relação aos responsáveis economicamente pelos domicílios, há uma prevalência de homens, em mais de $74 \%$ dos casos. As mulheres só são "chefes" economicamente falando em pouco mais de $25 \%$ dos casos. Em relação ainda às características econômicas do responsável pelo domicílio, a maioria, mais de 35\%, não tem o ensino fundamental completo e a quase totalidade não frequenta a escola (97\%).

No aspecto do lazer, mais de $96 \%$ consideraram serem inexistentes os atrativos turísticos da RA (DISTRITO FEDERAL, 2013), apesar da existência de um parque ecológico local (ANUÁRIO DF 2013). Por outro lado, mais de 80\% não frequentam parques ou jardins e, quem o faz, só o faz raramente.

Além disso, não há frequência a museu, teatro ou biblioteca, salvo por $5 \%$ da população, mas ainda assim raramente. Em relação ao cinema, mais de $30 \%$ o frequentam, mas apenas pouco mais de 3,5\% fazem-no com frequência. No entanto, a PDAD não conceitua o que seriam "raramente" ou "com frequência". Também não há o costume de leitura: mais de $75 \%$ não leem e, quem o faz, lê no máximo dois livros ao ano (DISTRITO FEDERAL, 2013). Cabe mencionar, no entanto, que na RA não existem museus, teatros ou bibliotecas públicas, salvo as bibliotecas que existem nas escolas. Em relação a shows, mais de $87 \%$ não frequentam e, quem o faz, na maioria vai, no máximo, entre uma e duas vezes por ano (DISTRITO FEDERAL, 2013).

A prática de esportes também é rara: mais de $80 \%$ não praticam, sendo que os que praticam jogam futebol (7\%), fazem caminhada (quase 6\%) ou atividade física em academia (3\%). Contudo, o principal espaço esportivo é o Parque da Cidade, em Brasília, distante mais de 25 da RA, freqüentado por pouco mais de $4 \%$ da população.

Quanto à "segurança" mais $85 \%$ da população declararam à PDAD não haver sido vítimas de crimes ou violências. Contudo, entre os que sofreram, os crimes mais freqüentes foram o roubo (mais de $45 \%$ ) e o furto (30\%), ocorridos na própria RA (mas não em suas moradias) por mais de $68 \%$ e, em mais de $18 \%$ dos casos, na própria casa.

Apesar dessa percepção de relativa segurança, no período de 2004 a 2009, a cidade era uma das dez mais violentas do Distrito Federal em número de homicídios, não 
tendo acompanhado o decréscimo que se seguiu, à época (NASCIMENTO, 2011).

Já no período 2010-2012 é possível aferir um aumento de mais de $10 \%$ da criminalidade geral a partir dos Relatórios Anuais de Criminalidade do DF, estando a região entre as 15 mais violentas. Cabe mencionar que, nesse período, todo o Distrito Federal teve um aumento médio de quase $6 \%$ na criminalidade, de forma que a evolução da criminalidade na RA se deu $4 \%$ acima da média distrital, sendo os crimes mais comuns roubo, furto a transeuntes e lesão corporal dolosa (DISTRITO FEDERAL, 2010a; 2011 e 2012a).

Os Relatórios Anuais de Criminalidade do DF em relação à RA da pesquisa não apresentaram dados quanto a tráfico de drogas, apesar do QEdu: Aprendizado em foco (2013) informar que o Distrito Federal é a unidade federativa com maior percentual de compra e venda de drogas nas proximidades das escolas: $53,2 \%$.

Cabe esclarecer que o QEdu é uma plataforma da Internet com informações sobre a qualidade do aprendizado em cada escola, município e estado do Brasil, que reúne dados sobre o aprendizado e o perfil de alunos, professores, diretores, bem como número de matrículas, taxa de reprovação e aprovação, abandono escolar e estrutura do sistema educacional brasileiro. Ele apresenta os mesmos dados disponibilizados pelo Instituto Nacional de Estudo e Pesquisa Anísio Teixeira (INEP), relacionados à Prova Brasil e ao Censo Escolar, mas de uma forma mais concentrada.

\subsubsection{A escola pesquisada}

A escola pesquisada localiza-se entre os territórios de maior vulnerabilidade da RA (DISTRITO FEDERAL, 2013 e 2013a). É uma escola da rede pública que atende os anos iniciais e finais do ensino fundamental, além de possuir educação especial, com turmas especiais, sendo uma classe com alunos com Transtorno Global do Desenvolvimento (TGD) e três classes para Correção Distorção Idade Série (CDIS) (QEDu, 2013; BRASIL, 2014).

Em relação à infraestrutura, possui banheiros, biblioteca, cozinha, laboratório de informática e de ciências, quadra de esportes e sala de atendimento especial. Há mais de 30 computadores para uso dos alunos e sete computadores para uso administrativo, mas o acesso à internet não é por banda larga. Além de computadores, a escola possui ainda aparelho de DVD, impressora, copiadora, retroprojetor e televisão para uso pedagógico (QEDU, 2014). O Projeto Político Pedagógico (PPP), de 2012 e 2013, por sua vez, informa que havia "sala de artes", posteriormente desativada para atendimento aos projetos de educação integral e ao reforço escolar, da mesma forma como a biblioteca foi também desativada para dar espaço ao refeitório/auditório. 
Trabalham na escola 87 profissionais ao todo, sendo os cargos da equipe gestora e pedagógica os seguintes: diretor, vice-diretor, supervisor, supervisor, secretário, quatro coordenadores pedagógicos, coordenador para a educação integral, três professores para a sala de recursos e orientador educacional, além de serviço especializado de apoio à aprendizagem (QEDu, 2013 e PPP, 2012-2013).

Em 2013 foram 1.167 alunos matriculados, sendo 489 nos anos iniciais e 678 nos anos finais do ensino fundamental. Em relação às atividades complementares realizadas pela escola, o INEP (BRASIL, 2013a) informa haverem 495 alunos matriculados em atividades relacionadas a esporte e lazer (artes marciais, atletismo, tênis de mesa), 495 em acompanhamento pedagógico de reforço (matemática) e 495 em canto coral.

Quanto ao aprendizado, 30\% dos alunos, em 2013, possuíam distorção entre série-idade, isto é, atraso escolar de dois anos ou mais, havendo, porém, uma situação progressiva de atraso: enquanto nos anos iniciais era de 14\%, nos anos finais chegava a 50\% no sexto ano, sendo a média de $47 \%$. Além disso, há um alto índice de reprovação, acima de $15 \%$, o que aumenta a distorção série-idade e a evasão escolar (QEDU, 2013).

Em relação aos projetos desenvolvidos, em 2013, foram 19 os específicos, individuais ou interdisciplinares previstos no PPP, entre eles o projeto de mediação social, direcionado, nesse ano, aos alunos da CEDIS. Conforme o próprio PPP o objetivo era:

\footnotetext{
Implantar o Programa Mediação Social (Cultura da Paz) para os alunos das classes de correção de fluxo durante o ano letivo de 2013. Mediar e sanar os conflitos existentes entre os alunos, e alunos e professores, com vista estabelecer um melhor convívio.
}

Além disso, a mediação de conflitos também está prevista no Regimento Interno da escola, como prévia às demais instâncias de disciplina.

Assim, tendo-se apresentado o objeto de estudo e o campo de pesquisa, será feito a seguir a apresentação e a análise dos dados. 
PARTE III -

ANÁliSE dos DAdos E CONCluSÃo 


\section{ANÁLISE DOS DADOS}

Na primeira parte deste trabalho foi apresentado o referencial teórico sobre escola, violência, conflito e mediação de conflitos. Na segunda parte tratou-se dos aspectos teórico-metodológicos, destacando-se a forma como a pesquisa se desenvolveu, como se deu geração e a tabulação dos dados, a qualidade política e ética além da apresentação do campo (o "Projeto Estudar em Paz" e a escola pesquisada).

Nesta terceira parte serão feitas a apresentação e a análise dos resultados, obtidos por meio das entrevistas, do grupo focal, das notas de campo e da análise documental, bem como a conclusão deste trabalho, que se propôs a avaliar o "Projeto Estudar em Paz". Ao final, será apresentada lista de sugestões como forma de contribuir para futuras reflexões sobre as perspectivas e possibilidades de aprimoramento desse projeto.

Para compreensão dos resultados desta pesquisa, iniciei com o mapeamento dos conflitos e das violências encontrados na escola pesquisada e, a partir disso, como o "Projeto Estudar em Paz" lidou, ou não, com tais conflitos, verificando-se se houve ou não impactos positivos do "Projeto Estudar em Paz" na escola pesquisada.

Considerando que o objetivo geral desta pesquisa é fazer uma avaliação do "Projeto Estudar em Paz", vale lembrar que essa deve se desenvolver conforme os objetivos e metas do próprio objeto de estudo, que constam da segunda parte dessa dissertação. Nesta seção, tais dados só serão mencionados na sua relação com os achados da pesquisa de campo.

Para contemplar os objetivos desta pesquisa acompanhei o desenvolvimento das atividades do "Projeto Estudar em Paz" de novembro de 2012 a outubro de 2013. Como já foi dito, minhas atividades eram principalmente administrativas, mas também participei das reuniões semanais, às terças-feiras, as chamadas "reuniões de coordenação", de discussão e preparação do desenvolvimento das atividades nas escolas.

Durante esse período, foi possível perceber a falta de preparo e de experiência da maioria dos participantes do "Projeto Estudar em Paz", embora se mostrassem muito interessados e comprometidos. A maior parte deles eram estudantes da UnB. O conhecimento acerca de mediação de conflitos, mediação social e das questões envolvendo o "Projeto Estudar em Paz" se dava na própria práxis, quase concomitante à capacitação dos próprios estudantes envolvidos.

Contudo, há militância: há engajamento em outras ações de cunho social ou, quando não, há o questionamento quanto às condições do mundo atual. Todos estão ali porque acreditam na possibilidade de transformação do modelo escolar atual, porque acreditam em 
promover a democratização do espaço escolar e ampliar os espaços de diálogo e discussão dentro da escola. Nesse sentido, as falas de Carmem e Rute, participantes do "Projeto Estudar em Paz", resumem seus ideais:

\begin{abstract}
A gente busca uma gestão democrática [na escola]: professores que dialogam com os alunos, orientadores e diretores que dialogam com alunos e funcionários que dialogam com alunos e professores, quer dizer, a nossa ideia é, através da mediação de conflitos, conseguir consolidar a gestão democrática da escola (Carmem. Participante do Projeto).
\end{abstract}

[A gente busca] trabalhar pela democracia participativa. [...] Começar aí a plantar essa semente de que todos temos importância, todos temos uma voz e todos podemos participar e construir algo coletivamente. Então, eu acho que a escola é o lugar ideal para que se aprenda isso desde muito pequeno. Quando você começa a trabalhar com essa ideia de que todos podem participar, começa a plantar a democracia participativa desde pequeno aí você aprende um monte de coisas: dialogar com o outro, que é diferente de você; a respeitar aquele que pensa diferente de você, a saber colocar a sua vontade, a sua necessidade, a se expressar. Então, a partir dessa auto expressão você começa a respeitar a expressão do outro, e aí eu acho que a gente vai ter uma sociedade melhor, mais participativa no futuro. E a escola não promove esse aprendizado, muito pelo contrário e esse ponto para mim é fundamental no projeto porque a gente ainda vê que há uma hierarquia: dos adultos, com mais poder no alto e os meninos ali ainda como objeto dentro da escola. Então a gente procura pelo menos equilibrar essas forças (Rute. Participante do Projeto).

Apesar do uso de expressões com conceitos diferentes, "democracia participativa" e "gestão democrática", a fala das entrevistadas denota que a mediação de conflitos e, no caso, o próprio "Projeto Estudar em Paz", são vistos como uma ferramenta de democratização da instituição escolar, ou, nos termos do enunciado em seu objetivo geral, "como instrumento para uma prática cidadã", o que vai ao encontro dos pressupostos da mediação social.

Contudo, antes de apresentar a análise, será feita uma apresentação da escola pesquisada a partir do olhar da pesquisadora.

\title{
6.1 A primeira impressão
}

A escola está situada numa área residencial de casas, em sua maioria, térreas, de um pavimento, com telhados cinza, sem muitas árvores, circundada por um muro alto, com pichações, seguido por arames farpados. À primeira vista, parecia escura, com concreto de mais, árvores de menos, gramas por aparar. O local onde os profissionais estacionavam seus carros tinha um aspecto de ter sido improvisado: havia poças de lama, em consequência das chuvas então recentes e tufos de grama espalhados com resto de cascalho. Visualmente, assemelhava-se a muitas outras escolas, tanto públicas quanto privadas, que se veem pelo Distrito Federal. Nada despertava estranhamento. 
Do lado de dentro ela não parecia tão escura. Havia um grande pátio aberto, circundado pela construção escolar. Pelo lado que eu entrei, pelo estacionamento dos professores, à esquerda havia uma construção, um bloco único, destinada à sala para os funcionários terceirizados, o Serviço de Orientação Educacional, a cantina e o refeitório. À frente uma quadra de esportes coberta, ao lado de uma construção direcionada à sala de atividades e de reforço, bem como às atividades da educação integral. À direita estavam as salas administrativas, tais como sala dos professores, a sala de atendimento psicológico, a copa, a direção, a coordenação e a secretaria.

O prédio principal de salas de aulas, de dois pavimentos, ficava perpendicular às salas administrativas e de frente à construção destinada à cantina e ao refeitório. No pátio aberto, de cimento, havia algumas árvores e bancos, nos quais parte das entrevistas ocorreu, e um canteiro meio abandonado quando cheguei, mas que, ao final do ano, havia sido transformado num espaço bem cuidado pela turma de Jardinagem.

Nesse ponto, é preciso lembrar, conforme expresso no capítulo cinco, que parte dos alunos integra a educação integral, possuindo atividades extras, entre as quais jardinagem. A turma fez ao longo do ano dois canteiros, um que não cheguei a conhecer, e outro que fica em frente às salas administrativas. Mais uma vez, parecia uma escola como tantas outras.

Ainda assim, eu estava ansiosa. Não sabia o que poderia encontrar. Conhecia a escola e a região pelos documentos oficiais e havia lido sobre violência no contexto escolar. Por ser a primeira visita, perdi-me pelo caminho e cheguei já no intervalo das aulas. Os estudantes espalhavam-se pelo pátio, alguns sentados no chão, outros andando ou correndo de um lado para o outro. Alguns pareciam ensaiar uma dança. Era grande a escola, eram muitos os estudantes e era alto o barulho. No entanto, fui me adaptando: havia cada vez menos estranhamento.

Já dentro da escola, do meu lado esquerdo, dois meninos "brincavam de brigar" sob o olhar da responsável pela portaria. Eu logo pensei: “ai, ai, isso não vai acabar bem...”. $\mathrm{Na}$ porta da diretoria, outros três brincavam de "se puxarem": um ficava dentro da sala e puxava um segundo aluno para entrar nessa sala. $\mathrm{O}$ terceiro, do lado de fora, empurrava. $\mathrm{O}$ aluno, então, acabava entrando, para logo em seguida sair correndo. Mas aí tudo recomeçava.

Fiquei olhando para eles, observando a cena, em frente da porta. Acho que vi o movimento de ida e vinda umas três vezes, até que perguntaram se eu queria entrar. Disse que sim e eles me deram passagem, indo para outro lugar. Entrei, apresentei-me à pessoa presente e fui convidada a aguardar: a pessoa com quem eu deveria conversar não estava no momento. 
Enquanto eu aguardava, Sheila, profissional da escola, entrou e se sentou numa mesa. Do lado de fora, passou outra mulher, Michele, também profissional. Sheila, então, levantou-se rapidamente da mesa e saiu correndo da sala, puxando Michele pela roupa e gritando, com o dedo em riste: "Vou reprovar você! Vou dar uma suspensão de três dias!". Levei um grande susto com os gritos que, então, só aumentou: Sheila começou a tirar o casaco da outra, em fúria. Michele respondia também gritando: "Você é que vai ser repreendida!". E continuaram, uma gritando com a outra, e também rindo, numa cena que, para mim, visitante de primeira viagem, era confusa e assustadora.

Tudo isso continuou até que Sheila conseguiu tirar o casaco de Michele e dirigiu-se, fazendo cara de brava, à Fernanda, outra profissional, recém ingressa na sala: "Olha que absurdo, Fernanda! Ela sabia que eu vinha com esta roupa hoje e veio com uma igual de propósito!”. Sim, elas estavam com roupas e estilo de sapatos iguais.

Já naquele momento todas apenas riam, sem gritos, e acho que sorri também, dando um suspiro de alívio. Minhas sobrancelhas, até então arqueadas, levantadas, devem ter voltado ao normal, assim como minha respiração, suspensa diante do susto. Tudo não passara de um momento de socialização num dia de trabalho. Uma pausa na rotina escolar. Em breve, tudo ficou calmo e eu então pude me apresentar. Começava assim a meu trabalho de campo.

O motivo desse relato inicial, além de descrever a escola, é mostrar meu estranhamento. Eu já fui estudante e também professora (se bem que apenas em faculdades) e tenho um padrão de relacionamento social. Havia lido e estudado sobre violência no contexto escolar e, naquele momento, o estranhamento estava colocado porque, para mim, aquilo era violência. E é nesse ponto que é preciso considerar: não o era na percepção das pessoas envolvidas. Ao contrário, era uma brincadeira entre amigas, aceita e compartilhada por todas, que foi inicialmente incompreendida por uma estranha, que não conhecia a dinâmica social do lugar e (ou) as pessoas. É aqui que pode se manifestar o ruído na comunicação.

Esse ruído não ocorreu apenas na relação entre mim e a escola ou o projeto. Ele acontece também entre os alunos, os professores e ainda entre os participantes do "Projeto Estudar em Paz”. O que é brincadeira para um, é desrespeito para o outro. O que é diálogo para alguém é apenas um sermão para outros. Democracia para alguns pode ser baderna e confusão. Os estranhamentos também são possíveis dentro do próprio grupo. E brincadeira e violência, conflito e diálogo, conversa e discussão vão se intercalando nas mais diversas percepções apenas com uma coisa em comum: o negativo, o violento, o feio nunca é o Eu, mas sempre o Outro. 
Daí a sutileza e a necessária delicadeza nesse trabalho de tentar não apresentar, simplesmente, o outro como violento. Não estigmatizar. E sim, buscar entender como uma escola que está inserida num contexto de violências reconhece-se como boa para se estar e trabalhar. Como os seus conflitos, vistos como negativos, podem então ser compreendidos como positivos e como, dentro desse contexto, insere-se o "Projeto Estudar em Paz".

\section{2 É uma escola boa}

A percepção inicial acerca da escola é positiva. Estudantes e profissionais a consideram um bom lugar para se estar ou para se trabalhar. Observando-se a Tabela 21 é possível perceber isso pela predominância de expressões positivas (boa, legal, gosto) em relação às negativas (ruim, chata, violenta). Cabe esclarecer, nesse ponto, que a palavra “normal” não foi classificada nem como positiva nem como negativa, e sim intermediária.

Tabela 21 - Percepção sobre a escola

\begin{tabular}{|l|c|}
\hline Percepção sobre a Escola & Número de Respostas \\
\hline Boa & 68 \\
\hline Legal & 49 \\
\hline Gosto & 42 \\
\hline Ruim & 28 \\
\hline Normal & 17 \\
\hline Chata & 5 \\
\hline Violenta & 5 \\
\hline \multicolumn{2}{|c|}{ Fonte: Dados da Pesquisa / N'Vivo ${ }^{2}$} \\
\hline
\end{tabular}

A representação da Tabela 21 pode ser observada pelo Gráfico 4, no qual se demonstra a proporção entre as palavras positivas, negativas e intermediária, com predominância da percepção positiva:

Gráfico 4 - Demonstração da proporção entre percepção positiva, negativa e intermediária

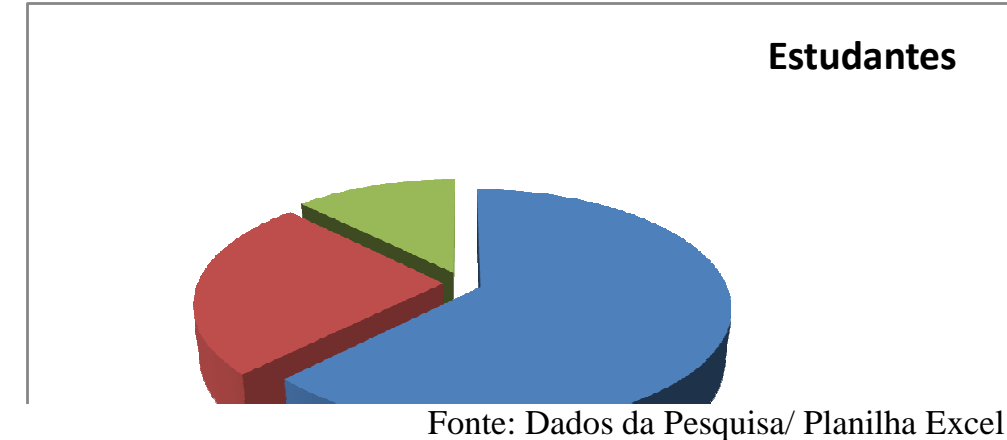

Mas afinal, por que essa é uma escola boa?

Para os estudantes, ela é boa porque "tem perspectivas de melhorias", "tem o ensino integral", "tem projetos, como o teatro e a mediação", "os meus amigos são legais", 
"os professores são gente boa, eu nunca levei reclamação", "Os professores conversam com a gente", “A gente aprende”, "Porque eu chego e falo com todo mundo”. Já para Marcos:

Ela é boa no contexto do que o ensino público pode e tem disponível pra gente. Ela é boa [por causa] da convivência entre alunos e professores, da interação, entre os alunos e o resto da escola. Tem projetos e os professores são bons também. [...] É boa a convivência dos alunos e dos professores (Marcos. Estudante).

Os profissionais também consideram que a escola é boa por uma autopercepção positiva: os profissionais veem a si próprios e a seus pares como “compromissados", dedicados ao trabalho. Há, assim, uma autoestima alta:

[os profissionais] são pessoas compromissadas. Eles realmente procuram fazer seu trabalho (Paulo. Profissional da escola).

O grupo de professores é um grupo muito bom. Os alunos melhoram com essa relação (Meire. Profissional da escola).

Os professores são bacanas e se dedicam a dar ao aluno um caminho, uma meta a atingir (Carlos. Profissional da escola).

Os professores são dedicados mesmo (Mariana. Profissional da escola).

Os professores cooperam um com o outro, os professores se ajudam (Aparecida. Profissional da escola).

Os profissionais também consideram tanto a estrutura escolar quanto as relações com a direção positivas, o que permite o bom desenvolvimento do trabalho:

A estrutura dela eu acho muito boa (Cristina. Profissional da escola).

A direção é tranquila, fala com todo mundo. A coordenação é legal, tranquila, há uma estrutura para a gente realizar o trabalho (Marli. Profissional da escola).

A coordenação, a direção, eles amparam bem o professor (Kátia. Profissional da escola).

Nós temos liberdade pedagógica para nos desenvolvermos em sala de aula e uma boa estrutura (Teresa. Profissional da Escola).

Há uma relação horizontal de igual pra todo mundo e a estrutura física da escola é uma estrutura boa. (Paulo. Profissional da escola).

Por fim, para os profissionais da escola, ela é boa em comparação a outras escolas. Existem escolas piores, então, a escola pesquisada é uma escola boa:

Aqui foi a mais tranquila que eu trabalhei até hoje. Não tem nenhuma ocorrência mais grave, a relação professor-aluno é bem mais tranquila, não é uma relação de terror, de hierarquia, não, é uma troca mais tranquila quanto a isso (Cristóvão. Profissional da escola).

Eu considero uma escola ainda bem tranquila, por outras que conheci e por outras que lá passei, é uma escola tranquila. Para mim, assim, eu me sinto muito feliz trabalhando aqui (Luciana. Profissional da escola). 
Diz o senso comum que uma mãe, ao falar sobre seu filho, em especial a um estranho ou a uma estranha, vai descrevê-lo como bonito, inteligente ou saudável. Pode ser difícil, nesse contexto, reconhecer as falhas, até porque elas poderiam ser consideradas as falhas da própria mãe, tanto com relação à educação quanto nos cuidados ministrados. Eu sou, então, a estrangeira que chega e pergunta a uma mãe: o que você acha do seu filho? A resposta inicial, esperada, é exatamente essa: ele é bom, é saudável, é forte, é esperto.

A escola pesquisada é esse filho amado. Ela é "o lugar de trabalho", para um, ou "lugar de encontro com amigos, de estudo" para outro. Ela tem de ser um bom lugar.

Essa percepção positiva não acontece apenas na escola pesquisada. Outras pesquisas que abordam questões sobre o ambiente escolar também mostram essa percepção, tal como encontrado em Debarbieux (2006) Abramovay et al. (2009), Fischer (2010), Torres et al. (2012) e o IBGE (BRASIL, 2013), que relatam que, em geral, a escola é vista de uma forma positiva, como espaço de sociabilidade (encontro de amigos, relacionamentos profissionais) e onde estudantes e professores sentem-se bem.

Para Debarbieux (2006), tal situação advém de uma percepção social quanto ao valor da educação e do papel da escola para uma dada comunidade. Assim, a escola é vista como boa porque é um espaço de socialização, de encontros, e porque é também percebida como importante para o grupo, para a comunidade ou para a sociedade.

A questão, nesse ponto, é que esse encontro de amigos ocorre num período muito curto do tempo escolar. Qual é o espaço que há para essa interação? Quando os professores podem efetivamente cooperar uns com os outros durante seu trabalho? Em que momento estudantes podem "brincar" com seus colegas de classe ou de escola?

Diante do poder disciplinar, que busca controlar o tempo, o currículo, o pensamento e as ações de estudantes e professores (FOCAULT, 1984 e 1999), o principal ponto positivo da escola, que é ser um espaço de socialização, fica diluído entre todas as atividades escolares previstas. Nesse contexto é que se pode compreender a fala de João, estudante, quando diz que sua escola "é boa e chata ao mesmo tempo". É boa porque há o encontro, mas é chata, por ser uma escola - a maior parte do tempo há obrigações e a impossibilidade de conversar.

Marcos, estudante, ao se referir à escola expressa "ela é boa diante do que o ensino público oferece". Carlos, profissional da escola, menciona que ela é "uma escola de uma comunidade carente", do que se pode supor que ela também é carente. Para Marisa, outra profissional da escola, "é claro que é uma escola pública. Tem deficiências". 
Essa "carência" ou "deficiência" pode ser melhor compreendida pelos pontos críticos da escola pesquisada, apresentados a seguir. Contudo, deve-se lembrar que é uma escola de uma região de vulnerabilidade social, que não possui toda a estrutura mínima de uma escola e com um índice alto de distorção idade-série, conforme visto no capítulo 5.

Já Maria, estudante, considera a escola boa pelas perspectivas de melhorias que existem, mesma percepção de Meire, profissional da escola, para quem "a escola vem melhorando" ou de Cristóvão, também profissional, ao relatar "este ano está mais tranquila".

A escola pesquisada, então, é boa porque existem outras piores ou porque ela mesma já foi pior. Nesse sentido é boa porque, pelo menos, não é pior. As coisas poderiam ser piores. E "graças a deus" que não são. Ou então ela é boa porque já se está acostumada com ela, conforme Sandra, estudante, para quem a escola é boa porque ela está lá "desde o prezinho" e agora já está terminando o fundamental. Ou seja, ela não estudou em outras escolas, não conhece outras realidades e essa é a escola onde seus amigos estão.

Enfim, é possível perceber que, mesmo dentro de uma percepção positiva dos entrevistados, a escola pesquisada não alcança o conceito do que seria uma "escola boa" mesmo para esses entrevistados, o que quer que eles considerem como tal. É mais uma acomodação a uma situação, uma naturalização das deficiências, o que já foi encontrado em estudos, como o de Torres et al (2012). É o que Gentili (1996 e 2009) chama de “inclusão excludente": há uma conformação geral em se aceitar que o acesso "às instituições públicas de qualidade" é um privilégio de poucos, não cabendo, portanto, a uma escola pública, de uma comunidade carente, ser "realmente boa". Assim, há o acesso a todos, mas a "qualidade" é restrita a poucos, que não são os estudantes da escola pesquisada.

\subsection{Conceitos gerais de conflito e de violência}

A partir do relato inicial sobre o primeiro dia de contato com o campo e o público alvo da pesquisa foi possível perceber a importância das percepções dos entrevistados sobre os conceitos envolvidos na pesquisa referentes a conflito e violências.

Nesse sentido, o "Projeto Estudar em Paz" vê os conflitos de uma forma positiva e as violências de uma forma negativa, separando essas em direta, cultural e estrutural, o que significa aceitar que o conflito faz parte da vida. Com isso, busca compreender suas causas por meio do diálogo, a fim de prevenir a escalada:

[...] a mediação realmente tem realmente essa questão de transformar o conflito, que não é para construir uma harmonia, mas compreender, aprender, o que está por trás daquele conflito. A proposta do programa é realmente compreender o conflito, porque esse conflito vai existir sempre (Marta. Participante do Projeto). 
O projeto [tem] esse pressuposto do conflito como positivo, da gente poder transformar esses conflitos de forma que ele não vire uma violência, que o fim do conflito não seja a violência, você trabalhar de que formas você pode conversar, estabelecer o diálogo, enfim, transformar o conflito em algo positivo para que ele não chegue na violência e você explicar o que é uma violência estrutural, o que é uma violência simbólica, a violência psicológica, de que forma essas violências estão presentes na nossa vida, de que forma elas podem impactar na escola, levar as pessoas a pensarem no que elas podem fazer, de que forma eles podem se mobilizar para que isso não se reflita na escola e, se refletir, entender que não é uma coisa dali, mas que acontece no contexto social como um todo e que se reflete dentro do espaço escolar (Júlia. Participante do Projeto).

Contudo, essa não é uma visão partilhada pela escola pesquisada, onde o conflito significa: problema, discussão, brigas, desentendimento e (ou) ausência de acordo, dentro da percepção geral dos entrevistados, ou seja, sem diferenciação entre profissionais e estudantes. A Tabela 22 mostra as principais palavras relacionadas a conflito, apresentadas pela ordem de contagem, seu percentual ponderado e as palavras similares incluídas:

Tabela 22 - Palavras relacionadas a conflito

\begin{tabular}{|c|c|c|c|}
\hline Palavra & Contagem & $\begin{array}{c}\% \\
\text { Poderado }\end{array}$ & Palavras similares \\
\hline Problema & 170 & 0,37 & Problema, problemas \\
\hline Brigas & 81 & 0,18 & briga, brigas \\
\hline Bullying & 14 & 0,03 & Bullying \\
\hline Xingando & 10 & 0,02 & Xingando \\
\hline Porrada & 9 & 0,02 & Porrada \\
\hline Xingamento & 7 & 0,02 & xingamento, xingamentos \\
\hline Agressão & 7 & 0,02 & Agressão \\
\hline Pancadaria & 2 & 0,00 & Pancadaria \\
\hline
\end{tabular}

Pela Tabela 22 é possível observar que, para os entrevistados, os conflitos são relacionados principalmente aos problemas enfrentados pela escola, ou as brigas que ocorrem no contexto escolar. Essa concepção negativa não é exclusiva deles. Jares (2002 e 2007), em pesquisa sobre avaliação de projetos relacionados à educação para a paz, menciona a prevalência da concepção negativa em escolas pesquisadas na Espanha. Ortega e Del Rey (2002), ao desenvolver um plano de gestão de conflitos no contexto escolar, consideram necessário "diminuir os conflitos em sala de aula". Nesse sentido, se algo precisa ser diminuído, excluído, é porque não é bom nem bem visto.

A partir de Arendt (2013), Weber (2004) e Focault (1984) verificou-se que a instituição escolar possui a priori uma concepção negativa de conflito. Por haver um foco na autoridade tradicional e no poder disciplinar, o conflito é visto como uma quebra da ordem que deve ser estabelecida. Sendo assim, são tomadas decisões para seu abafamento, que 
acabam por produzir a escalada e o surgimento da violência. Quando isso ocorre, a violência passa a ser confundida com o conflito (PASQUINO, 1995. ARENDT, 2013).

Com relação à violência, foi feito um gráfico comparativo entre as falas recorrentes dos estudantes e dos profissionais da escola pesquisa, conforme demonstra o Gráfico 5.

Gráfico 5 - Comparação entre a percepção de violência entre alunos e professor

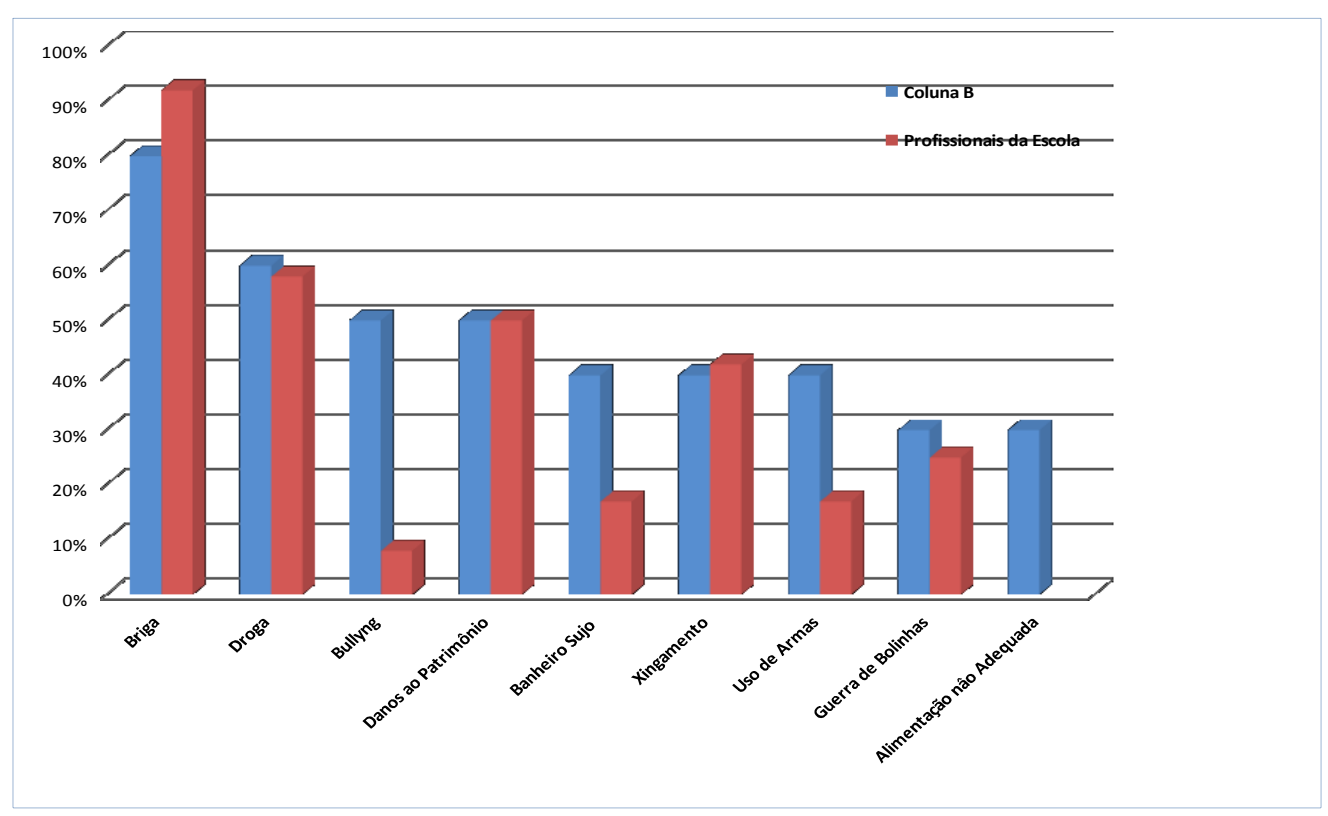

Fonte: Dados da Pesquisa / Planilha Excel

Assim, verifica-se que a violência, na escola pesquisada, relaciona-se a um amplo espectro de situações, desde criminalidade (drogas, porte de armas), violências subjetivas (brigas, guerra de bolinha, danos ao patrimônio) e objetivas (situação do banheiro e da alimentação dos estudantes). Observa-se também que alunos e profissionais compartilham a mesma percepção de violência subjetiva, mas não de violência objetiva e criminalidade.

Além disso, há, conforme previsto, confusão entre violência e conflito, expressa nas palavras briga, xingamento e bullying, comuns aos dois contextos, ainda que não sejam percebidos da mesma forma por estudantes e profissionais.

As diferenças, em especial quanto ao bullying, quase invisível para os profissionais da escola, serão tratadas nas seções específicas, mais adiante. Assim, os conflitos e as violências foram agrupados em duas grandes seções: na primeira, chamada "Caos Dialógico", serão discutidos os relacionamentos e a convivência no contexto da escola pesquisada, na segunda, "Violência? Tem muito não", trata das violências identificadas, de forma a abarcar todas as percepções de conflito e violências encontradas na escola 
pesquisada. Após cada seção será apresentada a forma como o "Projeto Estudar em Paz" atuou diante dos conflitos e das violências no contexto escolar.

Antes, porém, é preciso entender que essas categorias não são estanques. Há uma margem de indefinição, pois, como falam Charlot (2002) e Debarbieux (2006), na realidade da escola, os conflitos se mesclam, às vezes, uns sendo causa e (ou) consequência de outros. Essa separação tem apenas uma finalidade didática, mas ela coincide com o diagnóstico de Marta, participante do "Projeto Estudar em Paz", quando perguntada sobre as situações com as quais ela se deparou no cotidiano de sua experiência:

\begin{abstract}
Ah, então, era muito [conflito] entre aluno e professor ou entre os próprios alunos mesmo, que vem da violência que eles sofrem do lado de fora da escola, dentro de casa e até no caminho para a escola. E a questão estrutural, a falta de estrutura [da escola]. Bem, tinha muito essa questão de brigas, às vezes físicas, e da diferença, do tipo "ah, ela é gorda". O bullying tinha muito, e a gente percebia que era porque ela [a vítima] não fazia parte do ambiente, dos amigos, daquela pessoa que provocava esse tipo de violência. Com os professores era muito a questão da intolerância. Os alunos reclamavam muito do modo como o professor dava aula e aí o professor não mudava aquela forma, ignorava algumas confusões ali dentro de sala de aula e aí virava aquela bola de neve, até que uma hora explodia porque não há o diálogo entre eles. Então, há as agressões verbais, entre alunos e professor, ofensas e essa questão hierárquica, às vezes, da questão de um certo poder que o professor tem, os abusos.
\end{abstract}

\title{
6.4 O caos dialógico
}

Na escola pesquisada, conflito e violência relacionam-se a "brigas". Descobrir o que isso significa, quais são as suas causas e como a escola lida com essa situação são os objetivos desta seção. Para tanto, ela foi dividida em três partes: relacionamento entre estudantes, relacionamento entre estudantes e professores e relacionamento entre a escola e a família.

\subsubsection{Relacionamento entre estudantes}

Conflito entre estudantes foi uma das principais demandas da escola pesquisada que justificou a implantação do "Projeto Estudar em Paz". Tanto que, ao se questionar sobre a expectativa quanto ao projeto, todos os profissionais responderam que objetivavam a melhoria do comportamento dos estudantes. A questão é tão central que a palavra "alunos" possui conotação principalmente negativa, relacionada a brigas, indisciplina, agressividade e aos problemas da escola. Nesse sentido, foram identificados quatro tipos de conflitos: brigas (lato sensu), brigas de meninas, bullying e o fenômeno de galeras. 


\subsubsection{Começa com uma brincadeirinha e quando vê, vira um conflito}

Já era $1^{\circ}$ de novembro de 2013 e eu estava combinando entrevistas com profissionais, na sala da direção. De repente, chegaram dois meninos chorando: Gabriel estava "brincando" de passar a mão nas nádegas dos colegas. Júlio não gostou da brincadeira e passou a brigar e a xingar Gabriel. Esse, por sua vez, sentiu-se ofendido e bateu no colega.

Esse tipo de situação, de brigas e agressões físicas, é uma das situações mais comuns entre estudantes, em todas as escolas do mundo. Desde o Healthy Behavior in School Aged (HBSC), da Organização Mundial da Saúde (OMS), que pesquisa 41 países na Europa à América do Norte, até as pesquisas específicas sobre o Brasil, mencionadas ao longo desse trabalho, as brigas de estudantes aparecem como um fato recorrente do ambiente escolar, a ponto de Charlot (2002) considerar que faz parte da função da escola lidar com tais conflitos. Isso é que integra o processo de socialização.

Fsicher (2010) e Torres et. al. (2012), por sua vez, mencionaram também que os estudantes, em especial os adolescentes, possuem um tratamento permanente de jocosidade, mesmo no ambiente escolar, ao mesmo tempo em que não diferenciam os limites entre essa informalidade jocosa e uma crescente gradação da violência. Assim como no caso acima, essa realidade para ser presente na escola pesquisada:

\footnotetext{
Às vezes é uma brincadeirinha: começa jogando papel um no outro e quando vê já gerou um conflito. Começa brincando ali no empurra-empurra e quando vê gerou um conflito. É corre-corre pelo corredor, aí esbarra, aí começa uma briga (Aparecida. Profissional da Escola).

[O aluno] começa a brincar e daqui a pouco está brigando dentro de sala de aula, estão xingando palavrão (Paulo. Profissional da Escola).

Não tem um motivo específico, qualquer coisinha já dá briga aqui (Marcos. Estudante).
}

Em outras palavras, as brigas, em geral cometidas pelos estudantes do sexo masculino, começam por "brincadeiras" que, em algum momento, ultrapassam um limite e provocam os xingamentos, o bate-boca, a principal forma de briga, na escola pesquisada:

As brigas que tem aqui é mais de bate-boca (Sandra. Estudante Grupo focal).

Brigas das pessoas, mesmo, é uma xingando a outra (Carla. Estudante).

Os alunos xingam o tempo todo, brigam o tempo todo (Paulo. Profissional da escola).

Contudo, assim como no caso enunciado no início, há a possibilidade de que tais discussões, bate-bocas, xingamentos, passem às "vias de fato". Nesse sentido, na escola pesquisada, há mais de um relato de situações mais sérias: 
Eu já tive que separar briga, briga mesmo feia dentro de sala de aula. Um aluno um dia desses jogou a cadeira no outro que cortou aqui assim [mostrando o meio do antebraço] (Paulo. Profissional da Escola).

Estar passando no corredor e esbarrar e já é um motivo pra partir pra briga. O negócio deles é partir mesmo pra porrada, pra pancadaria. Eles não sabem às vezes ficar batendo boca, eles querem partir pra agressão física (Elisabete. Profissional da escola).

Aqui já teve casos de alunos brigarem dentro da escola e sair e ter tentativa de assassinato. As brigas aqui não são leves, não (Marcos. Estudante).

Ainda assim, há uma recorrência de falas de que as brigas mais intensas não são comuns, mas casos isolados. Para Sandra, estudante, "briga mesmo quase não tem. É só briguinha mesmo". Para Joana, também estudante, "tem escolas que é briga todo dia, aqui não tem esse negócio de muita briga. Se tem assim é uma ou duas”. Para Meire e Cristóvão, profissionais da escola, em 2013, praticamente não houve: "tinha muita briga entre os meninos antes [...] e não teve esse ano. Teve discussão de aluno com aluno, mas nada que seja anormal, como o que era antes" (Meire). Para Cristóvão, o ano de 2013 teria sido o mais tranquilo, "exceto por um caso de briga".

Diante dessas falas, como compreender o Gráfico 5 e sua relação com tais falas? Como explicar que, para a maioria dos entrevistados, profissionais da escola e estudantes, as brigas foram consideradas os principais conflitos dentro da escola ao mesmo tempo em que são citadas como raras ("um caso só")? Que tipo de "briga" é essa cuja ocorrência está diminuído e fazendo a escola se tornar mais tranquila? Que evento houve apenas uma vez 2013 ?

Trata-se, na verdade, de brigas com o uso de violência que ocasionam lesão corporal grave ou gravíssima, ou seja, com consequências irreversíveis na vida dos envolvidos. Foi esse o caso de um estudante que levara um tiro que o deixou paralítico. Conforme Cristóvão, profissional da escola, teria havido uma briga que foi à "vias de fato". Um dos envolvidos ameaçara o outro. Para Paulo e Cristina, esse último, com medo, teria feito uso de um revólver, ido à casa do outro e dado um tiro. Esse tipo de briga é que é raro na escola. Ou seja, ações de violência relacionadas a rixas, lesões corporais e "vias de fato" não são comuns, mas exceções à realidade pesquisada.

Com relação à presença de armas, brancas ou de fogo, dentro da escola, ela não é percebida da mesma forma pelos entrevistados. Enquanto os profissionais dizem que ocorre pouco, os estudantes mencionam que isso ocorre com muito mais frequência (Gráfico 5). Por outro lado, as brigas do tipo discussões e bate-bocas ou, mesmo quando físicas, leves, seriam mais comuns, porém em diminuição. 
Apesar disso, há relatos de que as brigas existem fora da escola: "as brigas, são lá fora" (Carla, estudante), "de bater mesmo, de brigar, só na frente da escola" (Sandra, estudante), "é lá fora, os professores só ficam sabendo no dia seguinte" (Cristóvão, profissional da escola).

Assim, há o que Debarbieux (2006) trata como uma espécie de proteção à escola: conflitos e brigas são mantidos afastados dela. Para o autor isso ocorre em razão ao valor dado à escola e à educação. Contudo, na escola pesquisada, os motivos são mais pragmáticos: a possibilidade ou não de punição, como indica Carla, estudante:

Aqui dentro até que não [tem briga] por causa, acho, que dos vigilantes. Mas lá fora, sim, porque eles [os vigilantes] não podem atuar fora da escola, a não ser aqui na frente. Aqui eles [os alunos] ficam na boa, mas quando sai se resolve. Então aqui dentro é uma coisa. A escola não se envolve quando não é dentro dela. E quando é tem advertência, suspensão.

Tal fala relaciona-se com os achados da pesquisa de Fisher (2010), bem como com a reflexão de Mosé (2013) e Silva (2010), de que a escola não se preocupa com o que ocorre do lado de fora de seus muros, mesmo quando ocorre exclusivamente com seus próprios estudantes. Assim, também não são efetivadas ações de prevenção ou de enfrentamento dessas questões. Além disso, a escola apresenta-se como um espaço dissociado da sociedade e da comunidade a qual pertence, desconsiderando, assim, o que não se relacione a sua própria preservação.

Um dos motivos observados que pode levar os profissionais entrevistados a não darem tanta importância às brigas, mesmo sendo citadas como ponto crítico da escola pesquisada, talvez seja o fato de serem vistas como decorrentes da imaturidade da própria idade. Isso pode ser percebido quando falam em "briga imatura", "os alunos são imaturos mesmo", "são meninos bem imaturos". Portanto, uma condição natural da idade:

[...] eles são muito imaturos. Apesar de a escola já ser de $8^{\mathrm{a}}$ série do ensino fundamental, eles ainda são muito imaturos. A maioria é homem, menino, e menino você sabe: é mais difícil de amadurecer (Aparecida. Profissional da escola).

Há, também, um contexto de gênero, na qual se naturalizam os aspectos vistos como inerentes a uma masculinidade dominante (relacionado ao poder, à força, à resolução de conflitos com base na violência), mas, ao mesmo tempo, de permanente infantilidade. $\mathrm{O}$ problema disso é que a naturalização causa a percepção de que "as coisas são assim mesmo" e nada resta a se fazer. 


\subsubsection{Briga mesmo, só de meninas}

Brigas de meninas é um fenômeno já identificado por Abramovay et al (2009), em pesquisa sobre a realidade das escolas públicas do Distrito Federal. Para a autora a valorização exacerbada à valentia e ao perigo como qualidades do masculino ainda permaneceriam, daí a maior incidência de comportamentos de risco entre os meninos.

No entanto, elas estariam sendo repassadas também às relações femininas, o que se mostrou comum nas escolas atendidas pelo "Projeto Estudar em Paz" identificado tanto em Furtado (2011) quanto em Gaspar (2012) e ainda em Carneiro (2014). Nesse sentido, parece haver um processo de promoção de violência e de agressão física como padrão de resolução de conflitos, mesmo por causas consideradas banais:

Os conflitos mais comuns na escola são de desentendimentos mesmo, de fofoquinhas, principalmente pelas meninas. Hoje o maior conflito é o desentendimento com as meninas por questões de picuinhas, bobagens, que acabam em tapas, que não haveria necessidade se estivesse realmente investigado e visse que aquilo é uma bobagem (Luciana. Profissional da escola).

Vou falar das meninas da sexta série brigando por causa de garotos e, sei lá, sandálias. Tipo assim: teve uma menina que queria roubar a sandália da outra. Aí elas brigaram (Carla. Estudante).

Aqui [na escola] é só briguinha mesmo, das meninas é que é briga [...]. Com as meninas você não pode nem olhar pra elas que elas já querem brigar (Sandra. Estudante).

Olha, a menina fica com um menino, beija e já tá achando que tá namorando. Aí a outra fala com ele e dá briga, dá fofoca (Margarida. Estudante).

No grupo focal, realizado com meninas, essas questões ficaram mais evidentes:

Tu tem um namorado e uma pessoa inventa fofoca que tu é corna. É, aí minha filha, aí pronto, aí é uma querer pegar a outra que não sei o que (Sandra. Estudante. Grupo focal).

É uma que chega e fica caçando conversa com a outra. Aí uma menina fala bem ali "a Kátia é falsa". Aí depois chega a outra: "a Sandra falou que tu é falsa, que você é encapetada, que ela não gosta de tu". Aí a Joana vai lá e fala pra Margarida: "eita a Sandra falou que tu é falsa e vai te bater e não gosta de tu porque tu..." (Joana. Estudante. Grupo focal).

Se eu não gosto da Maria, ah, eu fazia um inferno na vida dela! Se eu não gosto da pessoa, professora... Você não sabe o que eu já fiz com uma menina! Eu não gostava dela. Então, eu peguei uma caneta e quebrei essa tinta da caneta. A menina tava com uma calça branca e eu taquei na cadeira dela e ela foi lá e sentou. Todo mundo na sala perdeu meio ponto por causa de mim (Ana. Estudante. Grupo focal).

A fofoca é uma das causas consideradas "tradicionais" de brigas entre meninas (ABRAMOVAY et al., 2002), mas há também as agressões e lesões corporais traduzidas nas expressões "pegar", "bater", "tapas”. Os motivos para que uma situação dessas aconteça pode ser qualquer um, ou seja, "Se eu não gosto da pessoa" já é o bastante para uma briga começar. 
Brigas de meninos ou de meninas possuem dois pontos em comum: as causas são fúteis, sejam as "brincadeiras", no caso de meninos, as fofocas ou apenas "não gostar" de alguém, no que se refere às meninas. Além disso, ambas são vistas como "imaturidade" pelos profissionais da escola ainda que as brigas de meninas causem mais estranhamento, talvez pelos padrões vigentes de gênero.

Isso denota que o padrão de relacionamento e de resolução de conflitos entre estudantes da escola é a violência. São relações do tipo perde-ganha, em que há a necessidade de se mostrar ou aparentar ser superior aos demais e capaz de subjugar o outro: se alguém não gosta de algo, agride; se há um desentendimento, agride-se. Não há espaço para o diálogo ou para formas pacíficas de relacionamento ou de resolução de conflitos.

Essa é uma realidade comum à escola brasileira, percebida por Njaine e Minayo (2003), Abramovay et al (2002) e Paraná (2010) que concluíram que violência é uma forma de comunicação urbana da atualidade.

\subsubsection{Bullying por orientação sexual}

Eu entrevistava Raul, estudante, embaixo de uma árvore. Alguns amigos dele aguardavam por perto. De repente, um menino se aproximou por trás da árvore e ficou olhando para o grupo. Raul ficara incomodado e então eu percebi o motivo: o menino sussurrava baixinho "viadinho". Não muito alto, mas suficiente para Raul ouvir. Esse não foi um momento isolado. Conforme João, "as pessoas zombam dele [Raul]. Ele é gay”.

A pesquisa de Fischer (2010), sobre Bullying escolar no Brasil, conclui que não há um motivo exato para ser vítima de bullying: basta ser considerado diferente a partir do olhar do assediador. Na escola pesquisada o motivo parece ser porque Raul é visto ou percebido como fora de um padrão de sexualidade/afetividade arbitrariamente definido como único correto. Ele também rompe com o padrão de masculinidade ao utilizar entonações de voz ou trejeitos tradicionalmente vistos como femininos.

As consequências do bullying para a vítima são sérias: sensação de solidão, não aceitação, depressão, perda no interesse de estudar, abandono escolar, tentativa de suicídio (DEBARBIEUX, 2006. FISCHER, 2010. TORRES et al., 2012). Ou seja, a vítima é levada a outras situações de violência. No caso da escola pesquisada o estudante envolve-se em brigas:

O único bullying realmente que eu vejo é de um dos meninos que tem tendência homossexual e os meninos realmente martirizam ele. Ele sofre bullying. Aí é quando começa o conflito: esse aluno já entrou em brigas com outros alunos por causa desse bullying (Aparecida. Profissional da Escola). 
A pesquisa evidenciou que o bullying é pouco percebido pelos profissionais da escola: apenas Aparecida o mencionou. E, mesmo quanto a isso, percebe-se uma a sutileza na afirmação: o conflito começa quando o aluno entra em brigas, e não quando iniciou o bullying, o qual não é percebido como conflito. Daí, talvez, a ausência de atuação escolar nessa situação. Na percepção de Raul:

A direção vai conversar. Está na mesma coisa. O professor fala que tem de respeitar, mas só fala e nada acontece. A gente [ele e os amigos] não fala mais com a direção. Não acontece nada, não faz nada.

Há, assim, uma invisibilidade do bullying, em especial ao se considerar que, assim como na pesquisa de Fisher (2010), ele, de fato, ocorre em espaços sob o olhar da autoridade: a sala de aula ou o pátio. O resultado disso é justamente a legitimação dos agentes e a perpetuação da violência.

\subsubsection{Galeras, sim. Gangues, não}

Carla era visualmente diferente dos demais entrevistados. Seus cabelos eram pintados de vermelho. Seu rosto tinha uma maquiagem forte nos olhos, marcados com delineador preto. No nariz, um piercing pequeno. As unhas eram pintadas de preto. Nos braços havia várias pulseirinhas. A calça jeans possuía trechos desfiados, rasgados e ela usava uma camisa presa aos quadris que lembrava o uniforme dos grunges dos anos 1990. Sim, ela era roqueira. A maioria dos seus amigos também. Numa escola em que a predominância de gosto musical parecia ser do funk ou do rap. O resultado disso foi a hostilidade:

Eles tinham um grupo, tinham dois grandes grupos: o da galera do funk, o da galera do rock (Letícia. Integrante do projeto).

Antes eu falava nossa, aquelas pessoas ali, é tudo roqueiro, todo mundo junto... (Maria. Estudante. Fazendo cara de nojo).

[...] eles eram descriminados por que eles curtiam rock e a maioria curtia rap e funk que chegavam até a ser agredidos. Outros alunos tacavam pedra neles e tudo e eles ficavam num grupinho, muito acuados dentro da escola (José. Integrante do projeto).

Aqui é assim: [os alunos] são divididos em grupos (Carla. Estudante).

Galeras são "turmas de jovens com estrutura relativamente territorializada reunidas em torno de interesses geralmente alheios à violência" (COELHO, 2007, p. 15) como a "galera do rap" e a "galera do skate", não hierarquizadas, que podem manter rivalidades com outros grupos, inclusive envolvendo-se em brigas e agressões com outros grupos. Não se confundem com as gangues, grupos juvenis hierarquizados que se reúnem com o objetivo de realizar atos ilícitos (ABRAMOVAY, 2002. COELHO, 2007). 
Não foram identificadas gangues na escola pesquisada, e sim galera, reveladas não pela fala dos profissionais da escola e sim pelo discurso dos participantes do "Projeto Estudar em Paz" e dos estudantes, nas entrevistas e no grupo focal. Uma das razões para isso pode ser a sutileza das ações: há exclusão, os alunos não se misturam entre si. Se há agressão física, ela ocorre do lado de fora da escola. Como no caso de Carla, agredida por colegas, fora da instituição. Teriam jogado pedra nela, afirmam José e Miriam, participantes do "Projeto Estudar em Paz".

Infelizmente, na entrevista, Carla não mencionou o incidente. Falou do estresse "normal" da escola, "separada em grupos" cada qual de um jeito, sendo que dentro da escola os estudantes agiam de determinada forma e fora agiam de outra. Admitiu que ela mesma não conversava muito com as pessoas e que a maioria dos seus amigos, bem como seu namorado, também roqueiros, não eram da escola pesquisada. Em relação aos amigos do ano anterior (ela havia repetido o último ano do ensino fundamental), havia perdido contato: haviam saído da escola, logo ela não falava mais com eles. Não havia mais razão para isso.

Cabe esclarecer que não houve informações sobre outros incidentes violentos ocasionados em razão do gosto musical. Ainda assim, pelo menos até 2013, a escola pesquisada mostrou-se como um espaço dividido. Há grupos que não se misturam, como o de funkeiros e roqueiros, e que veem um ao outro de forma negativa. Esse dado, relacionado ao bullying mencionado anteriormente, indica a dificuldade de convivência na pluralidade, a dificuldade de aceitação do outro. Isso, contudo, não é um exclusivo da escola pesquisada, como indicam as pesquisas de Abramovay et al. (2002 e 2009), mas um fato da sociedade como um todo. Nesse sentido, a escola reproduz as violências encontradas em seu entorno.

Diante dessa realidade, o "Projeto Estudar em Paz" realizou curso de formação de mediadores sociais com os estudantes pesquisados. Foram três cursos ao todo, usando uma metodologia participativa e dialógica e com o conteúdo programático voltado à percepção e compreensão dos conflitos e violências e em formas de se lidar com tais situações por meio do diálogo e da ação coletiva. Isso ficou evidente na fala de todos os estudantes entrevistados quando mencionam ter havido uma transformação pessoal:

Eu fiquei uma pessoa melhor e procuro ser melhor a cada dia mais. Tipo toda vez que eu faço uma coisa eu opa, eu lembro da mediação e penso espera aí, calma aí, gente, e levo isso pro dia a dia (Maria. Estudante).

Eu era muito egoísta, eu não gostava de emprestar nada pra ninguém, eu não gostava de falar com ninguém, ficava só no meu canto, não gostava de nada aqui da escola, eu ficava sozinha. Aí depois eu comecei a falar com todo mundo. A gente aprendeu a não ter racismo, a ser mais educado com o povo, parar de ser tímido (Ana. Estudante). 
Eu aprendi a ser um pouquinho mais sociável (Carla. Estudante).

Ah, [eu aprendi] muito, muita coisa mesmo. O curso ensina a lidar com os conflitos, ensina a prevenir conflitos desnecessários Em casa mesmo depois do curso você vai vendo que tem algumas confusões que você não precisa, não tem necessidade de acontecer. Você meio que aprende mais a viver em sociedade melhor. Depois do curso a gente vai vendo esse negócio de convivência em família, você vai aprendendo a conviver melhor sem muita briga desnecessária (Marcos. Estudante).

Me ajudou bastante a refletir. Antes eu era muito alterada. Agora, eu relevo (Margarida. Estudante).

Antes xingava e brigava muito. Agora eu respeito mais (Raul. Estudante).

Pelas falas dos entrevistados, pode-se perceber que, para eles, o "Projeto Estudar em Paz" trouxe contribuições a medida que eles consideram que se tornaram mais sociáveis e mais dispostos a tentar compreender os conflitos, não apenas dentro da escola, como também na vida em geral. Margarida, por exemplo, era "alterada", brigava muito na escola, e a partir de então passou a relevar.

No grupo focal, o impacto e a transformação social individual também foram mencionados como o desenvolvimento da autonomia em relação à opinião de outros sobre elas próprias: "se a pessoa não gosta de mim, não estou nem aî" ou "ninguém é obrigado a gostar de mim". Além disso, o dissenso de opinião parece ser gerenciado de forma mais dialógica e menos violenta:

Se a pessoa olha pra mim e ela não gosta de mim, eu não estou nem aí. Porque ninguém é obrigado a gostar de mim, se não gosta de mim eu não estou nem aí. Se fala mal de mim eu também não tô nem aí! Pode falar o que quiser de mim que eu não estou nem aí também! (Sandra, estudante)

É igual aquele estado bate e volta: não vou bater não, não vou falar nada. Se quiser falar de mim, fala, ué. Porque ninguém é obrigado a gostar de mim! (Joana, estudante)

Antes era assim: "minha filha, está falando mal porque, hein?" Aí eu vi que a mediação é bem de conversa: "Não, não é bem assim. Por que você não gosta de mim?! Não, senta aqui, vamos conversar. Eu não sou desse jeito não... Eu sou só meio doidinha" (Ana, estudante).

Contudo, tal transformação não fora percebida apenas entre os estudantes participantes do "Projeto Estudar em Paz". Apesar de os relatos serem principalmente quanto ao aprendizado do próprio entrevistado ou entrevistada, também há menções a transformações positivas de terceiros, de outros estudantes:

Antigamente tinha até umas meninas lá no curso que eram barraqueiras. Com toda menina elas arrumavam confusão. Aí, com um tempo, elas mudaram (Maria. Estudante).

Os meninos até pararam de brigar! (Margarida. Estudante). 
Olha só o Flávio: nossa, ele era muito bagunceiro, nem era meu amigo! A mediação mudou ele (João. Estudante).

Assim, ao se perceber que há relatos tanto de transformação individual quanto de terceiros, o impacto positivo do "Projeto Estudar em Paz" passa a ter maior consistência no que se refere à transformação pessoal de estudantes. Nesse sentido, tais achados corroboram os resultados de outras pesquisas, como de Slyck e Stern (1991) e Bowdine e Crawford (1998) e ainda Furtado (2011) e Gaspar (2012) que apontam a mediação de conflitos como uma ferramenta de transformação pessoal.

Tal transformação não se refere apenas a uma "pacificação dos estudantes". Parece haver também uma proposta de educação emancipadora, que trabalha a conscientização e a possibilidade de transformação também social, conforme relatos abaixo:

Aprendi que tem como o governo melhorar, que tem como melhorar a educação lá na secretaria [de educação] (Raul. Estudante).

Aconteceu que eu comecei a pensar de outro jeito, de outro nível. Não ficar brigando por qualquer coisa e começar a pensar, a saber dos nossos direitos. Aprendi sobre desigualdades sociais, sobre bullying, que muitas pessoas sofrem por causa dessa discriminação: "ah, você é muito magra, muito gorda, você tem o cabelo natural, é muito baixa". Aprendi sobre essas coisas e muitas outras coisas também do nosso cotidiano. Tipo andar de ônibus. A gente tinha que ter um transporte melhor, eu não sabia que eu tinha esse direito e a mediação também me ajudou a conhecer essas coisas que eu não conhecia antes (Joana. Estudante).

Eu aprendi melhor o que é violência: tem a violência verbal, a violência cultural, a violência estrutural (Flávio. Estudante).

[Eu aprendi] sobre violência, bullying... Ah, eu nem fazia ideia do que era. Com o tempo é que fui tendo noção, noção até para parar com a violência com as mulheres (Margarida. Estudante).

Pode-se dizer, então, que o curso de mediação social melhorou a autoestima e a autonomia dos participantes frente à opinião de terceiros; auxiliou-os a lidar com conflitos de forma dialógica e aumentou a conscientização sobre a realidade social vivenciada, as violências e as possibilidades de mudança. Nesse sentido, o "Projeto Estudar em Paz" alcançou os objetivos da mediação social e apresenta-se como uma ferramenta de educação para os direitos humanos.

Isso não significa, contudo, uma transformação da escola ou de todos os envolvidos. Ao contrário, para os entrevistados, o curso não transformou a todos:

Pra quem fez o curso ele foi muito bom, foi bastante útil. Quem não fez acho que nem sente... Nem sabe que teve isso, porque a gente não interage com quem não tem esse contato com os mediadores (Marcos. Estudante).

Não adiantou muito pra uns meninos da minha sala, não. Mas para as outras pessoas, que entenderam, ajudou bastante (Margarida. Estudante). 
Mudou a gente que fez o projeto. A escola não mudou nada não, mas a gente mudou. O nosso ponto de vista mudou (Joana. Estudante. Grupo Focal).

Esse achado corrobora pesquisas de Slyck e Stern (1991) que indicam que projetos de mediação possuem a capacidade de influenciar e beneficiar apenas os estudantes que passaram pelos cursos, ou seja, os próprios mediadores. Não há, assim, a capacidade de multiplicação nem de influência sobre a escola como um todo, ainda que as transformações individuais sejam sensíveis.

Apesar disso, um grupo de profissionais considerou não haver contribuições positivas do "Projeto Estudar em Paz", especialmente no ano de 2013, período em que foi escolhida uma turma da Classe de Defasagem Idade-Série (CDIS) para passar pelo curso por ser uma "classe problema":

Nos outros anos foi melhor. Neste, não teve muito efeito, não (Teresa. Profissional da escola).

Uma coisa eu tiro: não adiantou a mediação. Eles tentavam, tentavam. A proposta foi ótima, só que não chegou ao que a gente queria: respeito com os próprios colegas e com o professor (Paulo. Profissional da escola).

Pode ser que tenha tido algum efeito, mas nas atitudes dos alunos no cotidiano deles, e nas matérias, eu não percebi mudanças. A gente achava que ia ser uma salvação mas não deu certo (Cristina. Profissional da escola).

Assim, na percepção desses profissionais, o curso de mediação social não teria melhorado o comportamento desses alunos. Eventuais mudanças foram consideradas decorrências de outras ações, tal como indicam Paulo e Kátia, profissionais da escola:

É igual eu já falei no início eles eram bem mais difíceis. Agora eles deram uma melhorada. Eu não digo que foi a mediação, eu não digo que foi só a intervenção da escola, mas eles deram uma melhorada (Kátia).

Bem, teve uma melhora dos alunos? Eu penso assim: teve uma evasão, muitos alunos desistiram. Esses piores, muitos desistiram porque sabiam que não iam passar, uns já foram presos... Alguma coisa aconteceu, sim. Diminuiu o efetivo de alunos, com isso diminui um pouco os conflitos dentro de sala de aula. Não que os alunos melhorassem. Os que estavam fazendo bagunça, os que não tinham compromisso com nada, que estão lá dentro, continuam do mesmo jeito. Diminuiu? Diminui, mas o que diminuiu o efetivo de alunos também. Não que esse negócio tenha contribuído para que isso tenha acontecido (Paulo).

A partir desses relatos é possível considerar que, apesar de ser visto como uma proposta de educação para os direitos humanos, formando sujeitos de direito, o "Projeto Estudar em Paz" encontra resistências dos profissionais da escola, o que pode desfavorecer sua atuação e o alcance dos resultados esperados. 


\subsubsection{Relações entre alunos e profissionais da escola}

Na seção anterior foram relatados os conflitos entre estudantes e a atuação do "Projeto Estudar em Paz" frente a esses conflitos. Referem-se, portanto, a relações entre pares, horizontais. Nesta seção, o mapeamento é sobre as relações de subordinação e autoridade entre professor e estudante. Nesse sentido, há uma percepção dos profissionais da escola de que os estudantes não respeitam seu trabalho, não se interessam por estudar e são indisciplinados:

Parece que eles não têm medo, não têm mais o respeito que, na época que a gente estudava, a gente tinha com relação ao professor (Elisabete. Profissional da escola).

São alunos extremamente indisciplinados. Comigo pelo menos eles nunca faltaram com respeito, mas eu já ouvi casos de outros professores: eles já levantaram a voz (Cristina. Profissional da escola).

Uma vez um professor, um bom professor, todo mundo gosta dele, foi dar um prova numa sala. Não era a turma dele, então, ele foi só dar a prova. Aí o aluno fez uma gracinha, uma brincadeira e o professor: "mas fulano, deixa de ser criança, está agindo que nem criança". E o aluno ficou nervoso, respondeu, xingou o professor. (Mariana. Profissional da escola).

Tal percepção é compartilhada pelos próprios estudantes:

Os alunos ficam xingando os professores, criticando os trabalhos e tal e todo mundo fica lá atrás, bagunçando (Sandra. Estudante).

Tem hora que o professor fala pra fazer silêncio, pra ele tentar explicar, aí a pessoa que não gosta do professor continua falando (Joana. Estudante).

Os alunos deveriam prestar mais atenção, sentar e ouvir o professor, dando mais valor. O professor fica lá falando e uns não dão valor (João. Estudante).

Aqui na escola é assim: professor não respeita aluno e nem aluno respeita professor. Professor responde a aluno e aluno responde ao professor, só que ao invés de tomar providência e levar o aluno pra direção, os professores continuam respondendo ao aluno (Margarida. Estudante. Grupo focal).

Para Cristóvão, profissional da escola, "o professor quer se trocar com o aluno", ou seja, bater boca, discutir, e complementa: "aqui tem muito, muito, muito disso".

Apesar de os profissionais revelarem uma percepção positiva da escola em razão de suas condições instrumentais de trabalho (a estrutura é boa assim como o é a relação entre pares), a relação de autoridade parece rompida: os e as estudantes não prestam atenção às aulas, não ficam em silêncio e professor e estudante, ambos, envolvem-se em bate-boca e xingamentos entre si.

A obediência à autoridade, conforme visto em Arendt (2013) e Weber (2004), é voluntária e decorre de algum tipo de legitimidade (o carisma, a capacidade técnica, o fato de ser democrática). Se há negociação, debate, bate-boca, coação ou violência, não há autoridade. Parece ser esse o caso da escola pesquisada. 
Contudo, mesmo na permanência da autoridade, resistências são comuns. Aliás, elas integram o processo de socialização humana (BERGER e outros, 1977; 1982. FOCAULT, 1984) e, ao se referir às classes pobres, situação da escola pesquisada, elas seriam maiores em razão das violências simbólicas do processo educativo (BOURDIEU, 1989. BOURDIEU; PASSERON, 1982).

Diante disso, duas são as opções: ou as instituições adotam uma vigilância mais sutil e fluída (FOCAULT, 1984. 1998), ou realizam o oposto: aplicam quaisquer ações, mesmo a violência, conquanto cumpram o papel de fazer obedecer (ARENDT, 2013). Para Assis e Vinha (2003) essa última opção é tomada diante da ausência de preparação dos profissionais para lidar de forma democrática com os conflitos. As decisões, assim, são tomadas com o único objetivo de eliminar o conflito. Parece ser essa outra realidade da escola pesquisada quando Cristóvão e Meire mencionam que há uma tendência de, por qualquer motivo, recorrer-se a terceiros:

Muitos professores querem extrapolar lá os limites da sala, querem levar pra direção, querem que a direção tome alguma providência porque eles já não têm mais saco pra aquele aluno (Cristóvão. Profissional da escola).

Todas as vezes que o aluno levantou com o pirulito, pegou o pirulito, levantou sem autorização, está em pé na janela, o professor mandava, ah vai pra direção, você que está em pé na janela, você que está mascando chiclete, você que está com o pirulito na boca na hora que não autorizo na aula (Meire. Profissional da escola).

A razão para tanto pode ser encontrada nas falas de Paulo e Aparecida ao considerar que "a gente" (eles, os profissionais da escola) "não pode falar nada com o aluno". Para Teresa, também profissional, ela "não tem como coagir" ou não pode "colocar a mão [bater] nos alunos" (Carlos. Profissional da escola). Observa-se que há a intenção do uso do castigo físico, em desconsideração a todos os direitos dos estudantes. Como não tal não é possível, os profissionais sentem-se incapazes e frustrados para lidar com a situação:

O aluno pediu pra ir ao banheiro e eu deixei ele ir. Sabe o que ele fez? Ele veio pra lanchonete comprar lanche! Mas o pessoal daqui da escola fala para não deixar o aluno vir pra lanchonete de maneira alguma, porque muitas vezes ele sai pra fumar maconha ou destruir o patrimônio. Mas muitas vezes o aluno fica insistindo e você não vai deixar ele mijar na calça. Então você deixa ele ir. Aí a supervisora encontrou com ele no caminho e falou "o que é que você está fazendo aqui?" e ele respondeu "ah, o professor deixou”. Eu não deixei ele fazer isso! Eu deixei ele ir ao banheiro [...]. No outro dia ele me pediu de novo pra ir ao banheiro e eu falei que não ia deixar. Aí ele ficou com raiva, meteu o pé na lixeira, jogou a lixeira, quase me acertou a lixeira, sentou na cadeira e ficou me xingando, falando besteira! Eu fui nele e falei pra ele me respeitar, que eu nunca tinha desrespeitado ele, que eu não tinha medo dele, apontei o dedo pra ele, sim, e falei "eu não tenho medo de você, não adianta você querer me ameaçar". Falei pra ele e aí ele começou a me xingar! Aí eu levantei ele e falei: "você levanta que você vai pra direção agora, não quero você dentro da minha sala, não!”. De lá de onde eu saí e até aqui ele ficou me xingando de palavras pesadas mesmo [...]. Quando eu cheguei na direção eu falei assim: "olha, eu quero levar esse menino pra dca [delegacia da criança e do adolescente]! 
Eu quero esse menino na dca agora! Vamos levar para a dca!” (Paulo. Profissional da escola).

Assim se dá a relação de autoridade e subordinação na escola pesquisada, ou, melhor, a ausência dela. Um desvio na obediência ou a resistência é vista como um ataque pessoal que exige a ação mais drástica: recorrer à Delegacia da Criança e do Adolescente (DCA). Por outro lado, uma simples contrariedade causa a provocação e a desobediência mais forte do aluno. Em momento algum há o processo educativo sobre a conscientização das consequências da situação anterior, não há o enfrentamento do conflito inicial. No entanto, o conflito que surge é interpretado com base em todas as situações passadas, desconsiderandose apenas a situação do momento.

Surge aí uma incoerência: por que antes o professor deixou e agora não? $\mathrm{O}$ professor sabe. O relato menciona, mas e o aluno? Ele só percebe que uma hora ele pode ir e outra não, conforme a vontade do professor. Aos seus ouvidos, isso soa como arbitrariedade e, contra arbitrariedades, resta rebelar-se. Aqui, a autoridade deixou de ter legitimidade, assim como percebido em outras falas.

\footnotetext{
A professora estava tentando explicar um negócio e a menina ficou gritando lá. Aí a professora mandou ela pra direção e falou que não ia passar mais nada pra gente (Joana. Estudante).
}

Os meninos falam alguma coisa com a professora e a professora responde que não leva ninguém pra direção ainda. Ela não leva pra direção, mas aí ela vai e xinga os alunos. Ixi, ela já deu o dedo pra nós! (Joana. Estudante. Grupo focal).

[O professor] pegou a menina e tacou lá na parede, lá fora, porque ela estava conversando. E aí ele fica na sala, fica sentado falando que é um super-herói. Ele senta na cadeira e fica com os braços assim oh, em cima da mesa falando que é um super-herói e vai voar (Maria. Estudante grupo focal).

Ou seja, além da agressão física, a forma de dirimir os conflitos se dá na coação ou na simples negação ao direito à educação dos estudantes, reforçando a quebra da legitimidade e da autoridade.

Conforme visto pelos relatos, os estudantes não ficam inertes a essa situação, Sandra, estudante, lembra que alunos até reclamam com os professores, mas esses "acham ruim" e não melhoram. Como resultado "fica todo mundo lá atrás, bagunçando". Se os alunos buscam uma segunda instância, a direção, por exemplo, ouvem "que a gente não tem razão, porque fica bagunçando também”. No grupo focal, Maria também mencionou tal situação:

Quando a gente vai lá na direção reclamar [da professora] ela fala que é mentira dos alunos. Aí não fazem nada! É a nossa palavra contra a dos professores. A gente foi na direção e ninguém acreditou na gente (sobre o caso em que o professor jogou uma aluna na parede). 
Assim, se de um lado a escola apresenta a violência dos estudantes como um ponto crítico, de outro, legitima a violência profissional e silencia a voz dos estudantes. Não há o reconhecimento ao conflito. Nesse sentido, eles são deslegitimados e, institucionalmente, é a atuação violenta dos profissionais que é legitimada. Dessa forma, um aluno que xinga merece ir à DCA. Por outro lado, um professor que agride fisicamente uma aluna, o fez porque não tinha opção, porque foi provocado ou porque a turma estava bagunçando. $\mathrm{Ou}$ ainda pior: ele não fez e os alunos mentem.

Vê-se nos relatos mencionados o desentendimento que Rancière (1996) considera não apenas um conflito em relação a um objeto de interesse (ir ao banheiro, respeitar o professor, por exemplo), como também sobre o direito à palavra, à condição de estar no conflito, enfim, sobre quem define quais são os reais conflitos escolares. O abafamento ao conflito, no caso, denota não apenas a ausência da legitimidade do conflito no contexto escolar, mas revela uma instituição que não se posiciona conforme os valores da democracia como modo de vida e de relacionamento (LEFORT, 1991).

Nesse sentido é que o "Projeto Estudar em Paz" surge como uma proposta para fomentar relações mais democráticas na escola, ao considerar, conforme Miriam, participante do projeto, que um ponto importante dele é equilibrar as forças na escola, onde os adultos possuem mais poder e os estudantes são "ainda como objetos".

Sendo assim, o curso de formação em mediação social contribui também para melhorar o comportamento dos estudantes em sua relação com os professores. Conforme os profissionais da escola que notaram alterações positivas, há uma melhora na autoestima e na expressão corporal nos participantes que auxilia o trabalho em sala de aula: Os alunos que participaram do curso aprenderam sobre como dialogar com o
professor. Se você pede impondo ou se você apenas pede, a forma, tom de voz, diz
muito sobre isso. Se você pede num tom que incita a briga, o outro vai e responde
com briga. Então, ele aprendeu a pedir pro professor e a solicitar os direitos deles,
por exemplo, na nota: "professor, eu gostaria de ver aquela nota", um filme, um
vídeo... Eles aprendem a lidar com o tom da voz e a expressão corporal. Eu lembro
de dois alunos, três na verdade, que ficou bem nítido isso: eles tinham um gesto,
uma coisa muito agressiva de falar e depois eles aprenderam a segurar os ombro e já
não tinha mais a questão do "quê que é?" [falando em tom de deboche] (Meire.
Profissional da escola).

Conseguiram mudar a postura deles (Elisabete. Profissional da escola).

Eu percebia a autoestima. Eles se sentiam parte de alguma coisa e colaboravam mais com tudo e melhoraram muito o comportamento (Kátia. Profissional da escola).

Cristóvão, por sua vez, lembra que numa sala, na qual dera aula no ano anterior, de 2012, havia dois mediadores e que tal sala: "era a sala mais tranquila que eu tinha: não tinha aquele grupinho que não falava com outro grupinho", o que facilitava seu trabalho. 
Contudo, a mudança não pode ser apenas unilateral, ela deve se operar tanto entre estudantes quanto entre professores. Enquanto isso não ocorrer, serão comuns comentários como o de Carla, estudante: “a gente estando lá, [no curso de mediação], a gente está um passo um pouquinho à frente de saber lidar com as pessoas, e eles [os profissionais da escola], não". Ou seja, enquanto os estudantes participam do curso e aprendem melhor a lidar com seus conflitos e as pessoas, inclusive com os professores, esses se mantêm numa postura que dificulta as relações democráticas e o processo de aprendizagem. Daí a importância de que todos da escola participem do curso de formação em mediação social.

Houve um curso de formação direcionado aos professores, em 2013. De acordo com os profissionais que dele participaram, o curso teria colaborado para uma maior sensibilização na compreensão de conflitos:

\begin{abstract}
Ah, eu achei interessantíssimo! Aumentou a minha percepção. Às vezes o aluno não está agredindo por agredir, é um hábito dele, ele já foi agredido e ele continua. É importante para pensar o aluno no mundo dele, lá fora, compreender o contexto. Eu não tinha esse olhar, quanto à agressividade do aluno, de ver o mundo dele. Foi interessante. Trouxe essa coisa da afetividade (Marli. Profissional da escola).
\end{abstract}

Eu achava que não havia diferença entre agressividade e violência e comecei a entender que realmente há uma diferença, há uma cadeia de acontecimentos que levam ao conflito e a fatores mais graves (Cristóvão. Profissional da escola).

Essa questão sobre o conflito. Pra gente antes era só briga. Mas a gente viu que tem vários tipos (Meire. Profissional da escola).

Em outras palavras, os professores passaram a refletir que as dificuldades de relacionamento com seus alunos e alunas podem ter causas multifatoriais. Houve uma sensibilização no sentido de que um estudante com quem se tenha um desentendimento pode ter sido vítima de violências anteriores (ele já foi agredido e ele então passou também a agredir), que há várias causas e tipos de conflitos e isso, ainda que não justifique certas ações, podem abrir espaço para um diálogo e uma aproximação. Contudo, essa sensibilização não se revestiu de um contexto prático de gerenciamento do conflito em sala de aula:

A gente recebeu a informação só que, em sala de aula, os professores dizem: "eu tenho cinquenta minutos na sala de aula!”. Então é difícil lidar com o conflito do aluno nesses cinquenta minutos. Normalmente o que ele faz é encaminhar para a direção (Meire. Profissional da Escola).

Se eu estou vendo um conflito na sala e eu não estou sabendo lidar, eu não quero saber qual a raiz do conflito, a gênese, o que está por detrás daquilo e etc., etc,. Eu quero resolver a questão, separar a briga (Cristóvão. Profissional da escola).

Dar voz aos alunos é interessante, mas eu tenho de ensiná-lo a fazer também. Eles ainda têm de fazer as atividades! (Marli. Profissional da escola).

Por tais falas, percebe-se o quanto os profissionais estão envolvidos em suas atividades escolares a ponto de não sobrar tempo nem espaço para que se dediquem a 
questões como os conflitos em sala de aula, mesmo que isso também faça parte de suas atividades cotidianas. Quanto a isso, o "Projeto Estudar em Paz" não conseguiu efetivamente sensibilizar tais profissionais. Um dos motivos para tanto pode ser a falta de clareza da proposta do "Projeto Estudar em Paz", conforme se evidencia da fala de Paulo, profissional da escola, quando diz que "tem de ser explicado qual a importância do projeto, qual o nosso papel nisso tudo, porque o professor tem dez turmas e outros projetos também, precisa ser motivado a isso".

Assim, para os professores que demandavam um processo de gestão de conflitos em sala de aula, o curso mostrou-se teórico, de sensibilização, sem resolver suas demandas efetivas: a de ser uma ferramenta para lidar com as relações e os comportamentos de estudantes em sala de aula. Em outras palavras, eles não se sentiram completamente atendidos, gerando resistências.

Como resultado, houve pouca participação. Para Cristóvão, profissional da escola, a pouca participação deu-se por desinteresse. De fato, a partir dos relatos abaixo é possível ver que alguns professores sequer se lembravam da existência do curso e outros simplesmente confirmaram que não participaram de todo o processo:

Não teve um curso para os professores. Teve umas palestras aí. Teve uma que eu participei (Paulo. Profissional da escola).

Nós tivemos esse ano o curso pros professores, mas ele não foi efetivo, porque tinham os atendimentos com alunos, os procedimentos normais da escola [junto com o curso] (Meire. Profissional da escola).

Houve uma aula do curso (Cristina. Profissional da escola).

Teve acho que uns seis encontros. Eu participei de um ou dois (Mariana. Profissional da escola).

Eu só fui a um encontro (Teresa. Profissional da escola).

Percebe-se, assim, que houve falta de envolvimento desses profissionais na proposta do "Projeto Estudar em Paz" e críticas como: "ele não foi efetivo". O não envolvimento nas atividades do "Projeto Estudar em Paz", não apenas da escola da pesquisa, mas das escolas como um todo, era constantemente mencionada por seus participantes durante as reuniões de coordenação. Essa resistência já foi identificada em outras pesquisas realizadas tanto por Furtado (2011) como por Gaspar (2012).

Contudo, a razão para tanto não seria a falta de aportes práticos, mas o desinteresse dos profissionais da escola na transformação que deve ocorrer na forma como tais profissionais e a própria escola lidam com os conflitos escolares. Para os participantes do projeto, a escola deseja a transformação dos alunos, somente, sem a mudança de suas práticas: 
Eu acho que eles esperavam uma transformação imediata, uma coisa muito rápida e quando viram que era um pouquinho mais lento, porque ninguém vai e ah, aprendi, vou virar um anjinho, não. Não é bem assim. Então, viram que os conflitos continuavam e a proposta do programa é compreender o conflito, porque esse conflito vai existir sempre, então eles desistiam (Maria. Participante do projeto).

Porque é um trabalho que envolve mudança de hábitos, de cultura, de pensamento, envolve abrir mão de uma série de questões, de repensar valores. Isso é muito dolorido, é muito complicado e nem todo mundo está disposto a fazer. E quando eles se deparavam com isso eu imagino que existia um baque assim: opa, isso aí não vai dar certo, não vai funcionar (Letícia. Participante do projeto).

Eles ainda acham que dialogar com os alunos, que escutar o aluno implica perda de autoridade (Miriam. Participante do projeto).

O projeto mexe com a rotina da escola. E quando você mexe na rotina é natural que haja uma resistência por parte de grupos que querem manter uma zona de conforto. Eles enxergam como se fosse um trabalho a mais e eles não querem ter um trabalho a mais (José. Participante do projeto).

Os professores observam o projeto pensam "ah isso vai dar muito trabalho, estou aqui pra dar aula, não estou aqui pra nhenhenhem não" (Clara. Participante do projeto).

Eles acham que o projeto vai dar mais trabalho pra eles (Débora. Participante do projeto).

A ideia de sobrecarga de trabalho é confirmada pela fala de Cristóvão, profissional da escola, ao explicar o desinteresse dos profissionais:

[...] os professores se acham sobrecarregados e às vezes são sobrecarregados, sim, com muitos projetos, muita prova, muita nota pra entregar, muito trabalho etc.. Eles pensam: "ah, mais um projeto? Pô, eu vou trabalhar pra caramba, já trabalho pra caramba e ainda mais um projeto?! Não, não quero saber. Não quero mais saber de projeto, quero trabalhar, fazer o que eu já faço e pronto".

Além disso, esses profissionais consideram que as relações na escola pesquisada já são horizontais o suficiente, conforme diz Paulo, "aqui não existe essa de manda quem pode, obedece quem tem juízo". Para Cristina, profissional da escola, o estudante já tem bastante "acolhimento, apoio, carinho", de forma que o que falta mesmo é "algo mais enérgico", ideia compartilha por Marli, outra profissional da escola, para quem a escola facilita e ajuda demais: "O aluno tem de ser responsável, disciplinado, com compromisso. Facilita-se tanto, ajuda-se tanto e esquecemos de educar para a responsabilidade".

Nesse sentido, os relatos sugerem que os profissionais da escola desejam um aporte técnico que lhes auxilie na resolução de conflitos em sala de aula, mas desde que não haja uma transformação efetiva de suas práticas, com a democratização das relações, e sim uma alteração no comportamento apenas do estudante. A demanda apresentada é, de fato, “acalmar" os alunos a fim de se permitir o desenvolvimento da atividade escolar. 
Há, assim, uma dissociação na visão do "Projeto Estudar em Paz" e da escola pesquisada quanto às propostas. Se o "Projeto Estudar em Paz" tem como propósito a democratização das relações no contexto escolar, a escola pesquisada desejava apenas ações que promovessem um melhor comportamento dos estudantes, sem alterações em suas práticas e nas de seus profissionais, de forma que a escola busca apenas favorecer a vigilância e o controle (FOCAULT, 1984). A partir disso, é possível perceber, ao longo do desenvolvimento das atividades na escola, choques inerentes a essa dissociação de percepção, que serão mais à frente analisados.

\subsubsection{Relações entre família e escola}

A relação entre família e escola é central para a mediação social no contexto escolar. Daí a necessidade de o mediador social atuar como um facilitador dessa relação, favorecendo os seus processos comunicativos (FRANÇA, 2011. SIX, 2001; 2005). A ideia é, assim, despertar a percepção de que a educação, no final das contas, não é apenas da família, mas envolve todas as instituições sociais, entre elas, a escolar.

A participação da família na vida de seus filhos, principalmente no acompanhamento escolar, é fator de proteção contra violências e atraso escolar (IBEGE, 2013. FIX, 2010. TORRES et al, 2012. DEBARBIEUX, 2006. ABRAMOVAY et al, 2002). Daí a importância de um relacionamento próximo entre a família e a escola.

$\mathrm{Na}$ escola pesquisada, a percepção dos profissionais entrevistados é a de que as causas das brigas entre estudantes ou da dificuldade na relação entre professor e estudante é resultado da ausência dos pais na vida escolar dos filhos. Como diz Paulo, profissional da escola, tudo é devido aos pais.

Há uma responsabilização da família pelo comportamento dos filhos e pelo desinteresse nos estudos, de forma que a palavra "pais" está sempre relacionada a expressões negativas como "falta", "ausência”, "não tem participação". É o que se pode observar pela fala dos profissionais da escola, quando se referem à falta participação dos pais na escola:

Os pais dos alunos, eles não tem participação alguma [...]. Por isso é que eu vejo aí esse desinteresse todo por parte dos alunos. Os maiores problemas que eu vejo são a falta de compromisso dos pais. Poderia ser bem melhor se os pais ao menos tivessem aqui dentro junto com os filhos. Saber o que o filho vem fazer (Paulo. Profissional da Escola).

Os pais tem reunião, mas mesmo assim há uma certa resistência. Porque o pai pensa “gente, eu vou pra uma reunião de escola e o meu trabalho?" Ele coloca o trabalho à frente do filho (Kátia. Profissional da escola). 
(...) os pais são muito ausentes aqui na escola. Eles só vêm realmente quando são solicitados e em último caso, quando o menino já está levando advertência, quando o menino já está sendo suspenso (Aparecida. Profissional da escola).

A partir dessas falas é possível perceber que esses profissionais não se referem a uma participação da família na vida dos filhos, como indicam as pesquisas acima, mas que desejam sua efetiva presença na escola. Como já disse o próprio Paulo "seria melhor se os pais estivessem aqui dentro junto com os filhos". Meire, no entanto, pensa diferente:

[O maior problema na escola] é realmente a falta de vontade dos meninos estudarem. A ausência da família eu acho que conta muito, a ausência da família auxiliando os alunos na escola. Não a ausência da família na escola. Pai não precisa estar aqui todos os dias, mas ele precisa estar presente na vida do filho.

Apesar disso, para a escola, em geral, é importante a presença dessa família, tanto que se buscam efetivar ações que promovam essa aproximação, melhorando o relacionamento em geral. Contudo, tais ações mostram-se infrutíferas, conforme desabafa Mariana, profissional da escola, "Tem vez que tem mais professor que pais!" ou Luciana, também profissional, "A gente faz reunião, chama, faz palestras e aparecem seis pais!”.

Para os profissionais entrevistados, falta interesse da família em relação aos estudantes: "o pai coloca o trabalho na frente do filho", como diz Elisabete; ou na percepção de Luciana, para quem, diante de uma reunião, o pai diz "fala logo professora do meu filho que eu tenho de ir embora, trabalhar, fazer comida". Contudo, Aparecida, profissional, considerou que tal dificuldade pode se dar pela forma como a família é chamada à escola:

[...] se a gente chama o pai só no momento do conflito, os pais chegam defendendo o filho mesmo sem saber da situação, simplesmente dizendo meu filho não fez isso, não foi bem assim, não tem provas, a escola não tem câmera pra filmar e acaba defendendo o menino e a escola fica de mãos atadas nessa hora.

Diante disso, pode-se inferir que se a escola chama a família para lidar apenas com os aspectos negativos (as punições) de seus filhos e (ou) na hora em que o conflito já se encaminha para uma ação de violência, tal família pode não desejar estreitar relações com essa escola, nem mesmo em momento de festas, quando é convidada a participar e não comparece. Além disso, é possível considerar que o desejo dessa proximidade seja apenas para corroborar as ações da escola, em relação a punições e controle em sala de aula, e não o desejo de uma partilha ou uma vida em comum (ARENDET, 2005. RANCIÈRE, 1996).

Há ainda a percepção de que apenas a presença ou a "cobrança" da família é suficiente para o bom rendimento escolar e para melhorar a situação disciplinar de estudantes. Há uma relação de causa e efeito direta, como expressa Meire: “A gente percebe quando o pai cobra e quando o pai não cobra. Quando o pai cobra das crianças, o rendimento deles é melhor na escola, quando o pai não cobra, é ausente". Há, assim, falta de uma 
problematização de que ambas as situações dependem de um contexto amplo e complexo que envolve, inclusive, a atuação da própria escola.

Como a presente pesquisa indica uma falta de visão da necessidade de uma atuação conjunta, há a responsabilização de terceiros e a retirada da responsabilidade da própria escola em sua atuação, o que não é exclusivo da escola pesquisada (ABRAMOVAY et al., 2002. SILVA, 2010. FISCHER; 2010). Assim, ao mesmo tempo em que a escola exclui de sua função lidar com as ações que ocorrem fora de seus muros, como visto na seção sobre brigas, ela também o faz em sua função intramuros. Se do lado de fora ela não efetiva ações sob o argumento de que não é sua função, do lado de dentro ela responsabiliza a família sob o argumento de que também não é sua função. Mais uma vez, é Paulo que vem expressar essa ideia:

[A família diz] não sei mais o que é que eu faço. Como se nós, a equipe escolar, fosse obrigada realmente a resolver o problema do filho dela (Paulo. Profissional da Escola).

A escola, assim, não lida com conflitos externos a ela nem com os internos. Com que conflitos ela lida? Conforme visto, a ideia da escola dos paradoxos é justamente

essa. É um ambiente visto como de promoção de um direito social e espaço educativo, mas que não se coloca como tal. Daí a relação entre família e escola ocorrer dessa forma.

Para o "Projeto Estudar em Paz" a relação entre família e escola também parece ser importante, tanto que em seus objetivos ele prevê levar a proposta da mediação social para toda a comunidade escolar, inclusive pais, conforme visto no capítulo 5. Contudo, a proposta de o "Projeto Estudar em Paz" alcançar toda a comunidade escolar, o que inclui a família de estudantes, não se efetivou, ao menos na escola pesquisada.

\subsection{Violência? Tem muito não. Tem lá fora}

A partir dos achados na pesquisa, as violências foram classificadas em subjetivas, estruturais e duras. Cabe lembrar que essa não é uma classificação estanque, pois, na realidade das escolas, muitas das situações se mesclam umas a outras, sendo causa e consequências entre si. A classificação apresentada tem apenas uma função didática.

\subsubsection{Depredação e "guerrinhas"}

A pesquisa identificou, entre as chamadas violências subjetivas, perpetradas pelos indivíduos e, no caso da escola pesquisada, por estudantes, brigas, depredações (danos ao patrimônio) e "guerrinhas", expressas pelas chamadas "guerras de comida" e (ou) "guerras 
de bolinhas". Considerando que, em relação às brigas, já houve menção anterior, o presente tópico terá como focos principais as depredações e as "guerras de comida".

Danos ao patrimônio são as violências à escola expressas em depredação a carteiras, portas, muros (pichação) e, inclusive, à sala de mediação. Conforme os entrevistados, esses são casos comuns na escola pesquisada que, no entanto, teriam sofrido diminuição ao longo do tempo:

\begin{abstract}
Um ponto negativo da escola que a gente tinha era a depredação e foi sendo feito um trabalho [pela escola e] essa depredação diminuiu. Hoje em dia, praticamente, a pintura da escola é mantida o ano inteiro. Ela estraga, mas é reformada e tem que reformar por conta do desgaste mesmo diário, mas não tem mais depredação. A pichação é um aluno ou outro e o que eu vejo de positivo é justamente essa melhora da comunidade escolar, dos alunos, em diminuir a depredação (Meire. Profissional da escola).
\end{abstract}

Entre os casos de depredações, foram recorrentes os danos às carteiras escolares. Nesse sentido, Paulo explica como isso ocorre:

Eles [os estudantes] arrancam os parafusos para pegar o parafusinho pra ficar travando a porta por fora. Aí eles colocam o parafuso assim [fazendo gesto com as mãos] e prendem o professor dentro da sala de aula. Tem um professor que está com um saco cheio daqueles parafusos das carteiras (Paulo. Profissional da escola).

Entre os estudantes, Maria e Joana mencionam um quadro geral de depredação:

A escola pinta e faz as coisas, mas os alunos não zelam. Então, nas salas de aula eles rabiscam, quebram as mesas, as carteiras. São tudo nova e está tudo quebrado. É desagradável estudar com a mesa quebrada, com a carteira quebrada, com a parede rabiscada, com um quadro sujo ou rabiscado, porque eles rabiscam, picham tudo (Maria. Estudante).

Os alunos também rabiscam muito as mesas, as paredes. Todo ano a escola pinta as paredes, mas aí se os alunos deixassem limpas ia ser um dinheiro pra outras coisas, né? Mas eles sujam as paredes, quebram as mesas, as partes de botar os cadernos. Aí as cadeiras e as mesas, que são novas, agora parecem que já tem uns dez anos, de tão estragadas que estão (Joana. Estudante).

Conforme visto nos relatos, as carteiras escolares eram novas em 2013. Na realidade, elas chegaram no final de 2012, graças à atuação dos mediadores sociais da escola, após uma mediação coletiva. Foi uma ação, assim, surgida da demanda dos próprios estudantes do curso de mediação.

Pelos relatos, a partir das discussões sobre violência estrutural durante o curso de mediação social, os alunos consideraram que a situação dos encostos de suas carteiras escolares, até então de ferro, enferrujadas e desconfortáveis, seria uma violência estrutural.

Após pesquisas desenvolvidas pelos próprios estudantes, esses teriam descoberto que a escola, até então, era a única do sistema escolar que ainda não possuía carteiras com encosto de plástico, modelo padrão no sistema escolar do Distrito Federal. 
Com isso, os mediadores se organizaram e fizeram um abaixo-assinado junto à escola, recolhendo mais de 500 assinaturas. O documento foi levado à Regional de Ensino, onde os estudantes foram recebidos pela responsável pela pasta na época do ocorrido. O pleito foi atendido de forma que, em 2013, as carteiras da escola eram todas novas:

\begin{abstract}
O grupo de mediação procurou primeiro a diretora da escola. A diretora falou que a regional de ensino já tinha conhecimento e que até então nenhuma providência tinha sido tomada. Mas ao pesquisar mais chegou-se à conclusão que a violência era tamanha que a escola era única da rede do Distrito Federal que tinha cadeiras com encosto e acento de ferro. E aí no módulo de violência que a gente fala das violências eles aprendem o que? A primeira coisa é a rejeitar qualquer tipo de violência. Então eles falaram: não aceitamos essa condição. Aí, os próprios alunos pesquisaram um modelo de baixo assinado na internet, colheram assinaturas ligaram na regional de ensino e agendaram com a então coordenadora da regional de ensino e ela recebeu eles [...]. No início do ano letivo todas as carteiras da escola foram substituídas. E foi a única escola também da rede que teve cem por cento das cadeiras e carteiras substituídas, a partir do protagonismo juvenil, de uma ação dos próprios alunos (José. Participante do Projeto).
\end{abstract}

Depois que os mediadores reclamaram e falaram sobre as condições da nossa escola, a escola recebeu carteiras novas (Raquel. Estudante).

Houve a troca das carteiras da escola por causa dos mediadores (Marcos. Estudante).

Tentei acessar os documentos relacionados ao caso. Contudo, eles não foram localizados nem pela escola nem pela Regional de Ensino, até o final do período de coleta de dados. Ainda assim, os objetivos da mediação social nesse caso parecem ter sido alcançados, principalmente quanto à possibilidade de transformação social. Em relação aos objetivos específicos do "Projeto Estudar em Paz", a proposta de estimular o pensamento crítico dos estudantes quanto à mediação social, os conflitos e violências no contexto escolar bem como ao estímulo à incorporação da prática da mediação social como instrumento de diálogo, participação e de transformação foram atendidos.

Contudo, tal processo ficou restrito aos mediadores sociais, mesmo sendo uma transformação de toda a escola. Tanto é assim que, já em 2013, a principal referência ao caso é justamente sobre a situação de depredação das carteiras novas.

Outra situação específica mencionada pelos entrevistados foi a depredação da sala de mediação, que ficou destruída, restando só "uma paredezinha", conforme Joana, estudante. Quem narrou o caso de forma mais específica foi Elisabete, profissional da escola:

Este ano a gente conseguiu, na verdade arrumou, um espaço pra poder fazer uma sala [de mediação]. Essa sala foi feita com divisória e tudo mais, fechadinha, e a gente estava começando a se organizar para enfeitar, arrumar a sala e aí tivemos um problema de vandalismo. Alunos derrubaram a sala inteira. Foi tudo pro chão. Foi identificado quem fez, foram chamados os pais e tudo mais. E aí, teve a questão da reposição desse material e houve pais que se negaram a ter que pagar, que não tinham condições. E nós ficamos sem a sala porque o material tinha sido gasto. Agora pra escola repor esse material... 
A situação pareceu tão forte que uma das principais referências à palavra "sala" no decorrer da pesquisa foi justamente relacionada à depredação da sala de mediação. Tal depredação significou a impossibilidade de implementação completa do núcleo de mediação.

Nesse sentido, cabe esclarecer que a instituição do núcleo de mediação nas escolas atendidas pelo "Projeto Estudar em Paz" é precedida por uma intensa preparação. Em geral, são os próprios estudantes, formados na primeira turma, que decoram o espaço com fotos, cartazes, almofadas, tapetes, objetos artesanais produzidos pelos próprios estudantes ao longo do curso de mediação ou doados por eles. Na escola de São Sebastião houve até mesmo a pintura da "sala" de mediação, num tom lilás, considerado a "cor da mediação" e, após, uma festa de confraternização.

Em geral, as escolas são incentivadas a doarem móveis para esse núcleo: carteiras escolares ou cadeiras, armários e mesa redonda. Quando não é possível, há uma campanha de mobilização junto aos próprios participantes para buscar materiais que possam substituir aqueles móveis. Quatro cadeiras, que serão organizadas em círculo, são suficientes.

Inicialmente, a instituição do núcleo era um ponto central do "Projeto Estudar em Paz", pois seria nele que as mediações de conflito deveriam ocorrer de forma a garantir o sigilo e a confidencialidade dos temas abordados. Deveria ser um espaço em que as pessoas que participassem das medições pudessem se sentir à vontade para expressar seus sentimentos e (ou) ouvir o que o outro tivesse a falar.

$\mathrm{Na}$ escola pesquisada esse núcleo foi inicialmente instituído num banheiro desativado. Foram realizadas algumas mediações, mas o espaço era pequeno e causava desconforto. Daí o novo núcleo instituído numa pequena sala, de madeira ou compensado. Com a depredação da sala, as etapas de instituição de núcleo do "Projeto Estudar em Paz" não foram atendidas. Nesse sentido, é preciso considerar que boa parte das ações de multiplicação dos efeitos do trabalho dos mediadores pode ter sido prejudicada nesse processo.

Ainda assim, é importante lembrar que projetos de mediação apresentados por Finn (1995), Sorel (1955) ou Prutzman et al (1978) não possuíam núcleos de mediação: As mediações aconteciam no pátio das escolas, nos recreios ou bibliotecas, o mesmo se dando na escola atendida pelo "Projeto Estudar em Paz" apresentada por Carneiro (2014).

Diante disso, a pesquisa evidenciou situações de depredação, de descuido, de destruição da escola, inclusive quanto a áreas direcionadas ao próprio "Projeto Estudar em Paz". Da mesma forma como o ingresso da violência dura na escola, a violência à escola, expressa no dano realizado a seus bens, materiais e instalações, relaciona-se ao valor que é dado à instituição e à educação como um todo (CHARLOT, 2002. DEBARBIEUX, 2006). O 
estudante que depreda enxerga a escola como algo que não é seu, que não lhe pertence e, portanto, como algo ao qual ele não deve cuidado (ORTEGA; DEL REY, 2002).

O resultado é um ciclo vicioso: a depredação cria uma escola mal cuidada e traz a sensação de insegurança que, por sua vez, atrai mais depredação e ações de violências (TORRES et al., 2012).

Para Charlot (2002) a violência à escola é uma resposta à impotência diante da instituição escolar e de seus modos arbitrários e violentos de funcionamento, de forma que, quando não podem atingir as pessoas, atingem-se os objetos representativos dessas pessoas. Já Debarbieux (2006) vai considerá-la dependente dos processos de integração da escola à comunidade, de forma que ela seria minimizada num contexto em que a escola é vista como parte da comunidade, como um recurso e como um espaço de convivência. A depredação, assim, é uma ação em resposta a uma exclusão.

A presente pesquisa não conversou com os autores de vandalismos, para aferir as causas e os motivos de suas ações, mas verificou que há situação de silenciamento de estudantes frente aos conflitos, bem como situações de violência física e psicológica contra eles, ao mesmo tempo em que não há integração da escola à comunidade. É bem verdade que essa não é uma relação obrigatória, contudo, quando acontece cria-se um ambiente favorável à instituição de violências à escola. Tal violência, mais que simples ação individual, é uma atividade inserida num contexto social que, se não a legitima, ao menos a incentiva: é a forma que estudantes encontram para responder às injustiças que eles percebem ou à ausência de solução para seus problemas.

Essa circunstância pode ser percebida num tipo de violência à escola relacionada diretamente a violências estruturais: o fenômeno das "guerrinhas de comida".

A guerra de comida, de lanche, de biscoito ou de frutas é realizada pelos estudantes após receberem a merenda escolar. Nesse ponto cabe esclarecer que, ao contrário de algumas escolas em que os estudantes saem de suas salas e vão para um refeitório, cantina ou lanchonete, na escola pesquisada, o lanche é servido dentro da sala de aula.

Os estudantes simplesmente jogam seus lanches (biscoitos, bolachas, cereal, frutas) uns nos outros, desperdiçando a merenda escolar, que integra uma política pública nacional, além de sujar as instalações escolares e os próprios alunos, exigindo gastos maiores com a limpeza e manutenção, e correndo o risco de se machucarem (alguém sempre pode escorregar ao pisar num resto de alimento):

Ah, quando era cereal, e todo dia era cereal aqui na escola, a gente pegava o lanche e ficava brincando de guerrinha de cereal (Maria. Estudante). 


\begin{abstract}
Ah, os alunos jogam biscoito e melão (Flávio. Estudante).
Jogam biscoito até nos vidros (Aparecida. Profissional da escola).

Jogaram biscoito no olho da professora (Kátia. Profissional da escola).
\end{abstract}

Fica aquela sala toda bagunçada de comida, a gente não consegue dar aula (Cristina. Profissional da escola).

No grupo focal, Ana e Maria, estudantes, deram descrições da situação:

[Os alunos] tacam melancia na gente, tacam pão com salsicha... É, até pão com salsicha! Até salsicha tem para tacar! É a guerra! E não tem como controlar, não, porque é muita gente bagunceira pra poucas pessoas. Levam uns pra direção e ficam "cem" bagunçando aqui. É muita bagunça! Ocorre mais depois do intervalo. Teve um dia, eu não lembro qual fruta foi não, mas eu acho que foi melão. Nós [aponta para algumas colegas] viramos o alvo (Ana).

[Outro dia jogaram fruta na escada] Um menino passou a mão [no corrimão da] escada e depois foi passar a mão no rosto... Tadinho, véi! Ai, mas eu também, eu estava na escada e quase caí e aí olhei e uns meninos começam a rir de mim (Maria).

A guerra de comida manifesta-se como uma situação de caos. Não é possível perceber quem começou. Ela ocorre como uma onda, como uma multidão em ação: de repente, todos estão envolvidos. Parar, então, torna-se difícil. Conforme visto nos relatos, alguns são repreendidos, outros vão para a direção, enquanto outros permanecem e todo esse processo cria uma situação de legitimação. No entanto, não foram identificadas ações educativas (campanhas, palestras), por exemplo, com o objetivo de coibir tais ações, apesar de ter havido mediações coletivas pelo "Projeto Estudar em Paz" sobre essa situação.

O resultado disso é a sensação de impunidade, porque não se consegue punir a todos, e de perda da autoridade dos profissionais da escola: a guerra de comida ocorre em sala de aula, teoricamente sob supervisão, o que se pode perceber pela fala de Kátia (profissional da escola) quando diz que já teriam jogado biscoito num professor. Tal violência deve ser estudada conjuntamente às outras violências (CHARLOT, 2002), conforme se verá a seguir.

\title{
6.5.3 O lanche é ruim, o banheiro é sujo e há falta de professor
}

$\mathrm{Na}$ escola pesquisada, foram identificadas como violências estruturais: banheiro sujo; alimentação não adequada e a ausência de professores. A situação do lanche como violência estrutural foi reportada por estudantes e pelo grupo focal. Para eles, esse é um ponto crítico da escola que demanda melhorias:

É sempre igual, esquisito, sem sal, comida muito ruim, um tempero que mais parece de miojo, mas como a gente está com fome nem liga se está estragado ou não (João. Estudante).

Ele é repetido e acho que às vezes vem até estragado, sem sal (Sandra. Estudante). 
O lanche é muito ruim (Flávio. Estudante).

O lanche é repetido, acho que às vezes vem até estragado. Raramente comem a comida (Margarida. Estudante).

O lanche é sem sal e às vezes vem um biscoito com suco... É um gosto forte, um cheiro forte, muito forte, esquisito (Raul. Estudante).

Tem vez que eu fico com fome aqui na escola (Maria. Estudante. Grupo focal)

Vou falar que violência é esse lanche que a gente come bem aí. Isso é uma violência contra a gente! Isso é castigo! A gente é obrigada a comer esse lanche aí, e às vezes eu como porque eu estou morrendo de fome. O que a fome não faz, né? Você nem sente o gosto da comida, é só pra encher mesmo o bucho (Ana. Estudante. Grupo focal).

Cabe esclarecer que não houve menções positivas dos entrevistados sobre o lanche. Até mesmo alunos que não participaram da pesquisa, com os quais conversei informalmente no pátio e nos intervalos, foram claros em apresentar essa questão como um ponto crítico da escola. Ou seja, a merenda escolar não é bem vista e, como resultado, não agrada e não é consumida, abrindo espaço para, assim, ser descartada na "guerra de comida".

É preciso considerar que, como toda violência, a "guerra de comida" é multifacetada, não tem uma causa única. Ela integra as relações entre os estudantes, a relação entre professor e estudante bem como percepção de cuidado ou não com a escola e com a coisa pública (DEBARBIEUX, 2006). Contudo, ao ser considerado precário, ruim ou ainda estragado, o lanche está sujeito a ser descartado, no lixo ou numa "guerra de comida".

Tendo em vista essa situação, o "Projeto Estudar em Paz" realizou uma mediação coletiva com a então turma mediadores e a presença da "cantineira" e da direção da escola. Sua finalidade foi informar aos mediadores como se dá a escolha do lanche e sua distribuição junto às escolas públicas, conforme explica Maria:

A direção veio e falou que não eram eles, que eles não eram responsáveis pelo lanche e que não adiantaria falar "ai, vamos mudar o lanche", porque é a regional que manda o lanche contado. O lanche vem para o mês. Aí eu "ah, agora entendi". Até que foi legal (Maria. Estudante).

No entanto, não houve o alcance dos objetivos da mediação social (FRANÇA, 2008 e 2011) porque o processo comunicativo iniciado com os mediadores não foi estendido a toda a escola. Ele ficou restrito aos estudantes do curso de mediação. Além disso, não ficou acertado como se daria o acompanhamento das resoluções da mediação, de forma que a situação se perpetuou como prática rotineira dos estudantes.

Além da precariedade do lanche, a situação do banheiro também foi considerada uma violência estrutural levando-se em consideração que sua condição, como o forte odor, impossibilitaria a concentração dos alunos durante a aula: 
A gente não se concentra por causa do banheiro (João. Estudante).

Precisa melhorar a limpeza dos banheiros, o cheiro é tão forte que às vezes vem até a sala de aula (Raul. Estudante).

Por tal situação há a responsabilização dos próprios estudantes:

A escola faz a sua parte, mas os alunos não zelam (Maria. Estudante).

Os meninos sujam muito (Marli. Profissional da escola).

$\mathrm{Ou}$ seja, a situação do cheiro do banheiro, que atrapalha as aulas e a concentração e por isso classificada como violência estrutural, não se deve à escola, que "faz a sua parte", mas principalmente aos estudantes, que sujam muito, de acordo com as falas anteriores. Entretanto, o que é considerado como a parte devida pela escola refere-se apenas à limpeza e não a um processo educativo de uso de banheiro público ou de conservação. Nas palavras de Marli, profissional da escola:

Não tem um projeto da escola para conscientizar sobre a limpeza, é o pessoal da limpeza atuando e só (Marli. Profissional da escola).

Mais uma vez, encontra-se aqui o que Silva (2010) tratou como ações de simples manutenção do estabelecimento. É a escola dos paradoxos (GENTILI, 2009. PAIN, 2010) que se manifesta por uma ação que não se reveste de educação, mas apenas relacionadas a sua própria conservação. Daí não haver ações de prevenção, tanto em relação às violências diretas, como às brigas, ao bullying, às guerras de comida e ainda quanto ao uso comum de instalações sanitárias, como na escola pesquisada.

No entanto, em relação à realidade dos banheiros, além da limpeza realizada, outras situações surgem como necessárias à manutenção. É como fala Luciana, também profissional da escola:

O banheiro está sujo, a gente lava e aí descobre que o banheiro não dá descarga (Luciana. Profissional da escola).

Uma descarga que não funciona não é uma situação que dependa dos alunos ou da equipe de limpeza para resolver. Depende, sim, de um processo comunicativo eficaz: alguém precisa informar à autoridade competente o que acontece e outrem precisa agir diante da informação. Há necessidade, assim, de um processo adequado de administração das instalações.

No caso da ausência da limpeza, a pesquisa evidenciou que ela é percebida pelos estudantes como uma situação de violência ou de descaso, como diz Ana, no grupo focal, "o banheiro da escola é um descaso contra mim”, um fator possível para outras violências efetuadas por estudantes, especialmente relacionadas à depredação do bem. 
Contudo, apesar disso, não houve menções à atuação do "Projeto Estudar em Paz" frente a essa situação.

Assim, a simples responsabilização de estudantes, bem como se enfatizar o processo de limpeza em detrimento da educação, não se mostram ações eficazes para a transformação da realidade mencionada pelos entrevistados com relação à situação dos banheiros. Vale ressaltar que, mesmo em situações de constante depredação, causas e razões disso são muito mais complexas do que apenas responsabilização de certos grupos.

A percepção de violência de uma escola não se relaciona apenas aos aspectos de criminalidade, mas principalmente ao cuidado e manutenção, sendo segura a escola que é bem cuidada (TORRES et al, 2012). Ao mesmo tempo, o descuido na sua manutenção fomenta práticas de descuido.

Além dessas violências, também foi identificada nesta pesquisa como violência estrutural a ausência ou falta de professores, evidenciada na fala dos entrevistados:

A professora só falta. A gente não sabe nada da matéria (João. Estudante).

A professora só falta. Falta muito (Margarida. Estudante).

Essa semana mesmo teve um professor que não veio nenhum dia na semana, segunda, terça, quarta, hoje é quinta feira (Paulo. Profissional da Escola).

Falta muito professor e eu não consigo dar a minha aula (Marli. Profissional da escola).

Vários trabalhos, como Delchiaro (2009), Tavares, Camelho e Karsminki (2009), Zaponi e Silva (2009), Santos (2011), e Torres et al. (2012), apresentam a questão do absenteísmo profissional como um ponto crítico da educação brasileira. No entanto, neste estudo, não se buscou conhecer as razões dessas ausências na escola pesquisada tendo em visto que elas não foram associadas pelos entrevistados ao "Projeto Estudar em Paz".

\subsubsection{Violências duras}

Violências "duras" são as relacionadas à criminalidade (ABRAMOVAY et al., 2009. ABRAMOVAY; RUAS, 2002) e estão presentes na escola pesquisada por meio da venda e do consumo de drogas, do porte de armas e da lesão corporal. Em relação às drogas, foi o segundo tipo de violência mais citado, ficando abaixo apenas das brigas. Tanto é assim que, certa vez, estávamos eu e alguns profissionais da escola, conversando na sala de coordenação e, de repente, chega Luciana, também profissional e diz:

_ Gente, o professor me chamou agora... Tem dois alunos que teriam usado drogas. Estavam dormindo, quando cheguei. 
_ E aí? - perguntou alguém, ao qual Luciana respondeu:

_ O que eu poderia fazer?! Disse “deixa dormir”. Melhor dormindo que atrapalhando a aula, não é? Deixa dormir...

Em outra ocasião, houve um rebuliço geral. Uma agitação de professores. De repente, dois policiais entravam na escola e iam andando rápido para a quadra de esportes da escola. Fui atrás e, chegando lá, Elisabete, profissional da escola, contou: alguém teria visto alguns estudantes fumando maconha na quadra de esportes. $\mathrm{O}$ batalhão escolar fora chamado.

No final das contas, dessa vez, pelo menos, não havia nada. Os policiais conversaram com os estudantes, vistoriaram bolsas e mochilas e vasculharam nas áreas próximas à quadra. Não encontraram sinais de uso e se colocaram à disposição para outras chamadas. Na ocasião, a preocupação da escola era visível: a venda e o consumo de drogas são situações críticas, percebidas tanto por estudantes quanto por profissionais da escola:

Eu tenho alunos que usam drogas (Kátia. Profissional da escola).

A gente tem alguns problemas, não na escola como um todo, mas em alguns focos de alunos que usam drogas (Meire. Profissional da escola).

Nós temos alguns alunos aqui que, às vezes, entram com drogas (Elisabete. Profissional da escola).

Um dos problemas que atinge aqui bastante é a questão das drogas, que acaba entrando aqui junto com os alunos. Então, alguns alunos já entram com a droga, entram já sob efeito de drogas (Marcos. Estudante).

Conforme relatos, o comércio de drogas aconteceria próximo à escola:

Drogas aqui dentro eu nunca vi, não. Só lá na frente da escola mesmo, ali no portão, onde a gente entra. [...] Eles usam drogas na frente de todo mundo (Sandra. Estudante).

Muitos meninos ficam vendendo droga e dá pra ver às vezes eles vendendo droga aqui próximo da escola (Paulo, profissional da escola).

Com isso, há a possibilidade de ingresso de estudantes sob o efeito de substâncias ilícitas, como no primeiro caso relatado, assim como a possibilidade de uso nas dependências da própria escola. Flávio e Marcos, estudantes, bem como Paulo, profissional da escola, relataram algumas ocorrências do tipo:

Os moleques fumam maconha no banheiro e ali fora [apontando para o portão]. [Em relação à cocaína] eles colocavam na mesa, na frente da mochila. $\mathrm{O}$ professor não vê nada (Flávio. Estudante).

Um garoto daqui que estava sob efeito de droga interrompeu uma aula minha (Marcos. Estudante).

Ele [o aluno] estava drogado de um tanto que estava gritando no meio do pátio! (Paulo. Profissional da escola). 
Parece haver, então, tanto o consumo como a facilidade de acesso a drogas nas proximidades da escola. Isso favorece o uso também nas suas dependências, principalmente por estudantes do sexo masculino, conforme menciona Luciana, profissional da escola, ao relatar que o acesso às drogas parece ser mais fácil para os meninos em relação às meninas. $\mathrm{O}$ que vai ao encontro da pesquisa de Abramovay et al. (2009) e o HSBC (2011) que mostra jovens do sexo masculino como um dos grupos mais vulneráveis a comportamentos de risco, entre os quais o uso de drogas. Um dos motivos para isso é uma cultura que incentiva "provas de masculinidade" expressas em ações de risco e de agressão. Além das drogas, outra violência identificada foi o porte de armas, conforme relatos a seguir:

Um aluno entrou este ano armado na escola (Flávio. Estudante).

Foi no meio do ano acho que entraram armados aqui (Sandra. Estudante).

Uma vez um menino levou uma arma e apontou para a professora. Estava ameaçando, mas estava sem bala. A polícia chegou e as balas estavam dentro da mochila dele (Raul. Estudante).

Cabe esclarecer que os relatos acima se relacionam a um único caso, ocorrido no ano de 2013. Paulo, profissional da escola, esclarece melhor como se deu o ocorrido:

Pra você ter uma ideia apontaram até arma aqui pra mim já dentro da sala de aula.
Não só pra mim, mas pra mais duas professoras. Enquanto nós estávamos
escrevendo no quadro, o aluno estava lá apontando uma arma pra gente. Sabe, a
gente podia ter morrido sem nem saber como, por que, por quem. Como foi
descoberto? Através de um outro aluno. O aluno apontou [a arma] pra outro aluno
que contou pra mãe. Aí a mãe ligou pra cá dizendo que fulano tinha apontado a arma
pro filho dela, alguma coisa assim. Aí a direção ligou pra polícia. Descobriram
primeiro se naquele dia ele estava com a arma e aí descobriram que sim, ele estava
com a arma. Ligaram pra polícia. A polícia veio e já entrou querendo saber quem é o
menino e tudo. Abriram a bolsa dele e estava lá a arma lá dentro, carregada.

Além desse caso, também houve menções a "brigas" de estudantes que resultaram em situações mais sérias, caracterizadas por lesão corporal, conforme visto na seção sobre relacionamentos entre estudantes. Apesar disso, é preciso lembrar que, de acordo com a percepção dos entrevistados, as violências duras, ainda que sejam percebidas dentro da instituição escolar, são consideradas exceção e não integrantes da rotina. Tais brigas são, assim, externas à área escolar.

As violências duras são consideradas como integrantes apenas do entorno e da comunidade, ainda que nela ingressem por outros meios. Não são regras na rotina da maioria das escolas (DEBARBIEUX, 2006), mesmo em comunidades com um entorno violento. Tal violência é externa ao ambiente escolar e afeita à segurança pública, pouco havendo o que a escola poderia fazer, a não ser recorrer aos órgãos específicos, ou seja, de segurança pública, e questionar por que a escola não estaria protegida dessa situação (CHARLOT, 2002). Se as 
comunidades dessem valor à educação ou à escola impediriam o ingresso dessa criminalidade no ambiente escolar (DEBARBIEUX, 2006).

Quando isso não acontece, não há a atuação da chamada "proteção social" à escola, relacionada aos valores da educação e da escola para a comunidade, e sim uma degradação do sentido da escola, o que faz a violência ultrapassar seus muros e se manter presente com todas as mazelas.

Portanto, apesar de os entrevistados mencionarem que, em relação às violências duras, "não tem muito não" na escola pesquisada e que elas existem apenas no entorno escolar e na comunidade, percebeu-se nesta pesquisa que tais violências não estão isoladas da escola pesquisada: ela influencia tanto os estudantes quanto o contexto escolar como um todo. Em relação à atuação do "Projeto Estudar em Paz", ele não atua diretamente com as violências duras, o que corrobora os achados de Gaspar (2012) que, por sua vez, considera que a atuação do projeto dá-se de forma indireta ao fomentar o questionamento acerca das violências estruturais e favorecer o diálogo entre seus participantes.

\subsection{Uma escola que vigia, conversa e pune}

$\mathrm{Na}$ escola pesquisada, foram identificadas formas de gestão dos conflitos tanto preventiva (intervalo monitorado) quanto repressiva (tentativas de conversa e diálogo, punição e à recorrência ao batalhão escolar). Além dessas, o "Projeto Estudar em Paz" atuou também de forma preventiva, com os estudantes que participaram do curso de formação em mediação social quanto a posteriori, com o conflito instalado.

Considerando que o batalhão escolar é um terceiro e que as violências duras são vistas como externas ao contexto escolar (DEBARBIEUX, 2006. CHARLOT, 2002), nesta seção o foco principal serão as ações empreendidas pela própria escola para lidar com a sua realidade. Para tanto, procurou-se compreender no que consiste e como acontecem o intervalo monitorado, as conversas, os diálogos e as punições, quando ocorrem, quem as realiza e em face de quem.

\subsubsection{A vigilância}

O intervalo monitorado consiste na presença de uma dupla de professores que circulam pela escola, junto aos estudantes, durante o intervalo entre aulas. É feito por escalas e foi mencionado pelos profissionais da escola como um aspecto positivo do lugar: 
Os professores ficam circulando na hora do recreio, observando, vendo os meninos (Mariana. Profissional da escola).

$\mathrm{Na}$ questão da disciplina, a gente faz escalas dos professores no intervalo pra vigiar, pra não dar problemas no intervalo (Aparecida. Profissional da escola).

Assim, a função principal do intervalo monitorado é observar e vigiar os estudantes, para "não dar problemas", ou seja, evitar brigas. Há, assim, uma tentativa institucional de tornar o poder mais fluido, sutil, saindo da esfera eminentemente punitiva para a vigilância permitindo maior controle sobre as ações dos indivíduos sob o poder institucional (FOCAULT, 1984. 1999).

As brigas diminuíram, conforme visto no decorrer deste trabalho. Contudo, como também já visto, cada ação de controle cria outras ações de resistência, tão ou mais fluidas e sutis quanto o modelo estabelecido. Ou seja, evitam-se as brigas intramuros, mas não as ações sutis, como a exclusão e o bullying, nem as brigas extramuros. A possibilidade de uma melhoria no relacionamento entre profissional e estudante também não ocorre com o intervalo monitorado, o que poderia se dar diante da maior proximidade entre esses atores escolares em um ambiente mais descontraído, como o pátio e o recreio, de maneira que os conflitos continuam por atrapalhar a aula ou causar as guerras de comida. Daí a necessidade da escola usar ações repressivas.

\subsubsection{A repressão}

Para os entrevistados, antes de ser uma escola que pune, a escola pesquisada é uma escola que conversa. Isso pode ser percebido pela fala de Marisa, profissional da escola, ao considerar que um ponto crítico da escola seriam as agressões verbais entre alunas e alunos, as brigas de estudantes, e diz que para lidar com a situação:

A direção conversa, a gente conversa, eu converso [...] Diálogo aqui é muito comum.

Esse mesmo pensamento pode ser observado nas falas de Meire, profissional da escola, quando fala que, diante de um conflito envolvendo estudantes, a escola "conversa com eles [os estudantes]”. Mas tal conversa não é apenas com os estudantes, também se dá com a família e com os professores diante do mau comportamento de estudantes:

[...] a escola sempre está procurando chamar, cuidar, mandar bilhete, avisos pra comparecer aqui, quando o aluno está dando problema. Liga pros pais, muitas vezes até do telefone pessoal, pros pais dos alunos poderem vir aqui pra conversar sobre o filho dele (Paulo. Profissional da escola).

[...] a gente sempre trabalhou dessa forma, sempre conversando com os alunos, chamando a família [para conversar] (Meire. Profissional da escola). 
Quando a gente tem um desentendimento a gente chama o professor, o aluno, o pai e a gente conversa (Luciana. Profissional da escola).

A partir desses relatos, pode-se considerar que a escola pesquisada busca ser um local dialógico, no dizer de Paulo Freire. Ela acredita que busca encontrar formas de lidar com a pluralidade, ampliando os espaços de discussão, lidando com seus conflitos de uma forma plural, na base do diálogo, o que traz como consequência uma democratização do espaço público (LEFORT, 1991. RANCIÈRE, 1996). Isso é tão forte na percepção da escola pesqusiada que a própria Meire considera que, diante da atuação do "Projeto Estudar em Paz", eles também sempre fizeram mediação. O que esse projeto fez foi dar nome a esse diálogo.

Contudo, a conversa é considerada pouco eficaz, tanto por profissionais da escola quanto por estudantes. Assim é que Teresa considera que "conversa, chama a atenção, manda para a direção, mas não resolve. Eles [os estudantes] não ouvem. É tudo desvairado!”. Mesmo numa situação envolvendo consumo de drogas, Luciana informa que a escola conversa com os estudantes sobre os efeitos negativos "mas eles não têm discernimento de saber o quanto isso é ruim". Um dos motivos para isso pode ser a forma como essa conversa ocorre:

A conversa já é na briga, já é na hora do nervoso, quando já está todo mundo exaltado quando vai ver (Aparecida. Profissional da escola).

Em outras palavras, não há aspecto democrático e dialógico inicialmente imaginado. Na realidade, alguns relatos dessa conversa, presenciados no trabalho de campo, podem demonstrar como se dá o desenvolvimento desse processo. No caso já enunciado de briga entre dois meninos, porque um havia passado a mão nas nádegas do outro, a profissional da escola que os atendeu já começou falando, quando viu o primeiro chorando:

\footnotetext{
- O que você está fazendo aqui?! Sai, sai, sai, sai! Sai já daqui!

Quando o segundo entrou, ela olhou para o primeiro e disse, sarcasticamente:

- Ah, já sei porque você está aqui! Fica, então (Adaptação de anotação de diário de campo referente a $1^{\circ}$ de novembro de 2013).
}

Durante todo o processo de escuta, ela interrompia a fala dos meninos, batia a mão na mesa e falava com o dedo em riste: "Então, você estava mentindo!" ou "Ah, agora eu sei que é você que está mentindo!". Em qualquer sentido, isso não é um processo de mediação.

Da mesma forma, a conversa diante de um conflito em sala de aula não é um diálogo. Assim, quando Meire, profissional da escola, informa que, num conflito em sala de aula, o professor conversa com toda a turma, no geral, significa que o professor aplica um sermão. De acordo com a fala de Aparecida, também profissional da escola, quando a escola chama a família para conversar sobre a situação do aluno, já ocorre uma espécie de acusação. 
Denuncia-se à família a situação do ou da estudante e espera-se que ela acate essa informação. Em resposta, a família responde "a escola não tem provas, não tem câmeras para filmar".

A conversa e o diálogo são partes de uma relação igualitária. Conversa-se e dialoga-se com um igual porque se reconhece o Outro alguém com direito de ser ouvido e de falar. O diálogo, conforme expresso por Paulo Freire, implica ouvir o outro e o que ele tem a dizer. Não apenas ouvir, mas considerar e refletir e, a partir disso, construir algo conjunto, uma relação, uma solução ou uma conclusão. No diálogo há a construção de uma relação democrática porque se reconhece o Outro e o seu direito à fala (RANCIÈRE, 1996; 2004).

A pesquisa verificou que esse não é um procedimento da escola pesquisada. Não há o diálogo. Na realidade, diante do conflito, duas opções surgem, uma como a atuação de Flávio ao dizer "Fico calado, para não apanhar" quando questionado o que ele faz para lidar com as brigas e provocações de colegas, também estudantes. Ou então, como já previsto por Maquiavel (1999), Entelman (2002) e Deustch (2004) e expresso no grupo focal:

Esses conflitos quem acaba mesmo resolvendo são os alunos. Sempre sobra pra gente. E aí vai na porrada mesmo. Vai na porrada! [...] Como a direção não resolve o problema, os alunos vão na porrada mesmo. Aí vai lá fora, aí uns correm, outros apanham, mas aí depois que acontece tira do chão, liga pros pais. (Maria. Grupo focal).

A questão nisso tudo é que surgem sensações de impunidade e de frustração que acirram os sentimentos e fazem os conflitos tornarem-se mais intensos. Resta à escola, então, adotar outras soluções repressivas: a punição, expressa nas advertências, na suspensão e nas transferências. "O que é o máximo que a escola pode fazer?!”, pergunta Aparecida. Restam apenas as punições.

Contudo, a violência e a punição só funcionam quando há o medo (ARENDT, 2013; 2014. ASSIS; VINHA, 2003). Quando elas são usadas com regularidade, perdem a força e se tornam ineficazes. Essa é a percepção dos profissionais da escola acerca do resultado da aplicação das punições:

Os meninos hoje em dia pra eles, eu acho, isso aí já não é mais disciplina. Já é mais uma brincadeira. (Aparecida. Profissional da escola).

Quando dá uma advertência ou uma suspensão, eles acham bom, porque ficam em casa (Cristina. Profissional da escola).

A sensação que cria é de banalização. As punições são excessivamente utilizadas e acabam por não mais surtir efeitos, principalmente quanto a reincidentes. Nesse ponto, cabe esclarecer que a escola pesquisada previa, em seu Regimento Interno, a mediação de conflitos anterior às punições. Não foi possível observar nenhuma mediação, até porque, 
ao que tudo indica, não houve implementação dessa parte no regimento. Além disso, é preciso lembrar que o núcleo de mediação não foi efetivamente implantado na escola pesquisada.

Com isso, é assim que a escola lida com estudantes que cometem infrações:

Um menino teria xingado umas meninas de "sapatão". Eu só ouvia Luzia gritando, xingando (eu estava do outro lado do pátio e fui me aproximando), que não aceitaria esse tipo de coisa, que ele era um idiota, que ele não valia nada, que ela estava cansada de lidar com ele. $\mathrm{O}$ menino foi suspenso por três dias, mas em todo esse processo em nenhum momento houve uma explicação ou fala dele. Ele até tentava se justificar e falar, mas Luzia gritava falando para ele calar a boca (Adaptação de anotação de diário de campo referente a 5 de novembro de 2013).

Hoje, depois do recreio e de conversar com alunos ouvi Luzia gritando com uns meninos: _ Ai que ódio! Olha o que vocês fizeram! (Adaptação de anotação de diário de campo referente a 19 de novembro de 2013).

Essas situações revelam um quadro de violência psicológica (ESCARLATO; SILVA, 2011. NASCIMENTO, 2001) aliado a uma sensação de banalização da punição, criando raiva e escalada da violência.

Isso não significa uma posição determinista. Um aluno que foi punido, que se envolveu numa briga, que se deparou com um profissional que um dia gritou com ele, não necessariamente é um aluno que vá passar por processos de escalada de violência na resolução de seus conflitos ou depredar a escola. O que os resultados desta pesquisa sugerem é que a escola pesquisada não consegue sair de um ciclo vicioso de violências cotidianas diante da complexidade dos conflitos que a integram. Isso se dá nas escolas de uma maneira geral, o que poderia ser motivo para justificar a implantação e implementação de um projeto de mediação de conflitos.

\subsection{Etapas, metas, impactos e dificuldades}

Conforme consta no capítulo 5, o resumo da implementação do "Projeto Estudar em Paz" foi dividido em quatro fases, a partir das etapas mencionadas por Beleza (2012). Essas fases não são sequenciais, nem simultâneas, elas vão acontecendo ao longo do ano nas escolas atendidas, conforme o desenvolvimento das atividades, sendo aqui apresentadas em sequência apenas para fins didáticos. Eu as chamei de fase de conhecimento, de curso de mediação, de instituição do núcleo e de sensibilização.

A fase de conhecimento engloba o mapeamento da realidade da escola e da comunidade ao redor bem como da sua "rede social pública e privada", identificando-se as necessidades e recursos. Além disso, seriam feitas ações de sensibilização junto aos atores escolares para divulgar o "Projeto Estudar em Paz" e suas potencialidades. A partir das reuniões de coordenação, percebi que esse mapeamento da realidade da escola é 
principalmente informal, que ocorre em reuniões com os professores, orientadores e coordenadores da própria escola. É o levantamento das demandas da escola.

Em relação ao mapeamento de rede, que engloba a fase de conhecimento, não houve menções a essa atividade na escola pesquisada. De fato, tanto Furtado (2011) quanto Beleza (2012) e Carneiro (2014) quanto os relatórios apresentados no capítulo 5, consideram que esse é um ponto crítico do "Projeto Estudar em Paz", seja em razão de suas próprias questões estruturais (ausência de pessoal, de financiamento) ou da estrutura das instituições mapeadas. Tal percepção também foi encontrada no relato a seguir:

\footnotetext{
A gente precisa ter mais pessoas pra fazer o mapeamento da rede assistencial que a gente reputa da maior importância, mapear essa rede social, integrar a escola nessa rede. Precisamos de alunos pra fazer isso. Nós não temos apoio. E aí é um objetivo que a gente não consegue cumprir, infelizmente. A gente consegue cumprir com uma instituição: vai lá no CRAS [centro de referência de assistência social], conhece a coordenadora, ela se dispõe a ir na escola, conversar com os professores e não damos andamento porque falta gente pra continuar trabalhando nesse mapeamento (Miriam. Participante do Projeto).
}

A segunda e a terceira fases de desenvolvimento das etapas do "Projeto Estudar em Paz" referem-se aos cursos de formação e à instituição de um núcleo de mediação. Além dessa, ainda é prevista a última etapa, sensibilização, direcionada às ações de manutenção acompanhamento dos mediadores formados, avaliações e divulgação de resultados.

O objetivo dessas fases, em especial das fases dois e três, são estimular o pensamento crítico acerca de mediação social, conflitos e violências no contexto escolar; fomentar na escola pesquisada práticas socioeducativas pautadas na cultura de paz e de direitos humanos, justiça, democracia e cidadania e incentivar junto aos diferentes segmentos sociais a incorporação da prática da mediação como instrumento de diálogo,de participação e de transformação pessoal e social.

Na delimitação temporal da presente pesquisa, ou seja, de 2010 a 2013, houve a prevalência de curso de formação em mediação social para os estudantes. Para os docentes, foi realizado apenas um curso, no início de 2013. Não houve formação para os demais membros da comunidade, ao contrário do previsto nos objetivos específicos do "Projeto Estudar em Paz" e presente entre os eixos da mediação social (FRANÇA, 2011).

Com isso, verifica-se que, na prática, trata-se de um projeto de mediação por pares (HEREDIA, 2008. BOLDINE e CRAWFORD, 1998) e não de enfoque global, ao contrário do previsto em seus documentos. 
O ingresso no curso de formação normalmente é voluntário. Há a divulgação nas salas de aula ou convite por amigos já mediadores. Os relatos abaixo apresentam a predominância de divulgação em sala de aula:

Eles passaram na sala perguntando se agente queria fazer (Ana. Estudante).

Passaram as mulheres em cada sala e quem quiser participar vai lá falar com elas (Carla. Estudante).

Foi o professor que falou que tava tendo, aí eu fiquei sabendo e eu me inscrevi (Sandra. Estudante).

Eu fui fazer porque a irmã da minha amiga fez e gostou. Nós duas fizemos (Joana. Estudante).

A minha irmã já fazia e me chamou. Eu soube através dela (Maria. Estudante).

Apesar disso, em 2013, na escola pesquisada, foi escolhida uma turma específica para participar do curso de formação, de forma que todos os estudantes da turma passaram pelo curso. Conforme Margarida, estudante, a turma foi "escolhida" e todo mundo fez. Ainda que Margarida desconheça o motivo dessa escolha, ela se deu porque essa classe é considerada mais "difícil" pelos profissionais da escola:

São tudo doidos, parecem tudo atrapalhado aqueles meninos [...] Eu pensei que podia fazer essa mediação com o pessoal da aceleração, uns que são os que dão mais trabalho, e foi justamente isso o que eles fizeram (Paulo. Profissional da escola).

Tem-se a visão de que as classes de aceleração são mais problemáticas porque são aqueles alunos que são repetentes de vários anos. [O curso esse ano] Começou com esses alunos (Cristóvão. Profissional da escola).

Na verdade, essa turma é uma turma difícil, vamos dizer assim. É uma turma muito difícil. Tentamos implementar esse projeto com ela para ver se a gente conseguia, sei lá, alguma melhora (Luciana. Profissional da escola).

Com isso, verifica-se que houve, ao menos nessa turma de 2013, um processo de "estigmatização" dos estudantes que participaram do curso de formação em mediação social. Os participantes eram os alunos "mais problemáticos, mais difíceis" a partir da visão dos profissionais da escola, sendo objetivo do curso efetuar maior controle sobre eles. A participação foi, então, involuntária. No entanto, a pesquisa não verificou a versão dos participantes do "Projeto Estudar em Paz" quanto a esse processo.

Apesar da pesquisa não poder apresentar dados definitivos quanto a isso, a forma como a escolha se deu pode justificar a percepção negativa dos profissionais da escola quanto aos resultados no ano de 2013 bem como dos próprios estudantes quanto ao fato de que o curso "não adiantou para todos". Isso porque, conforme visto no decorrer deste trabalho, a percepção negativa foi principalmente quanto ao ano de 2013 , o que indica a 
importância de que a mediação não seja uma proposta obrigatória nem curricular nas escolas, mas uma proposta de autonomia e de escolha dos próprios estudantes.

Ainda em relação ao curso, cabe esclarecer que a proposta pedagógica do "Projeto Estudar em Paz" envolve uma metodologia dialógica, com dinâmicas, "brincadeiras", nas palavras dos estudantes, participativa e colaborativa. Tal metodologia permite o diálogo entre todos, o que foi percebido pelos estudantes:

Tinha as dinâmicas também que eram bem legais. Conversar também com os professores era legal (Carla. Estudante).

A gente falava dos conflitos, de como agir, a gente fez umas brincadeiras também, fazia cartaz, um monte de coisa. Foi bom porque a gente ficava todo mundo junto e tentava ajudar os outros também. A gente falava de tudo (Sandra. Estudante).

Era Legal. Tinha brincadeiras que fazia rir e se divertir muito. A gente falava sobre a gente, sobre o governo, sobre o que ele podia fazer no dia a dia (Flávio. Estudante).

Tinha as brincadeiras. A gente brincava muito. Era o que eu mais gostava (Marcos. Estudante).

Processos cooperativos e dialógicos, baseados na participação dos estudantes em atividades e dinâmicas de grupo e na partilha de experiências, melhoram a socialização como um todo (SANCHES, 2005. ORTEGA; DEL REY, 2002. DAMIANI, 2008), pois, quando os diversos pontos de vista são expressos e ouvidos, há uma relativização do próprio ponto de vista, o reconhecimento do outro e a superação do egocentrismo. Daí tal metodologia ser comum em projetos de mediação (HEREDIA, 2008. BOWDINE; CRAWFORD, 19998. JARES, 2002, 2007).

No grupo focal também chamou atenção dos estudantes a forma de tratamento dos participantes do "Projeto Estudar em Paz", resumida aqui na fala de Maria, estudante:

Nossa, as pessoas eram mó educadas! É, educadas! Falavam com a gente, abraçava a gente e não tinha dessa não... Na sala de aula, o professor quer saber só a parte dele. Não quer saber da gente. Aí já na mediação, eles davam atenção pra gente, perguntava se você tava bem. Essas coisas. Todo mundo lá dava atenção para todo mundo. Lá todo mundo conversava e falava e pronto.

Assim, além da metodologia dialógica, o cuidado e a atenção dos participantes do "Projeto Estudar em Paz" causaram estranhamento positivo aos estudantes. Isso demonstra, de um lado, que essa não é sua realidade e, de outro, a necessidade de se sentir ouvidos e respeitados.

Outro fato que chamou a atenção nesta pesquisa foi a divulgação do "Projeto Estudar em Paz", como no caso da reportagem do programa da TV Globo, "Fantástico", que foca a resolução do conflito entre pares e entre estudantes e professores. A escola pesquisada conheceu o projeto por meio dessa reportagem, conforme explicam os relatos abaixo: 
Um professor viu no Fantástico a reportagem e nós fomos conhecer (Meire. Profissional da escola).

Eu vi a primeira reportagem no Fantástico e um professor nosso ele também viu. Se eu não estiver enganada, essa reportagem era de São Sebastião. Então, ele viu e começou a buscar informações sobre esse projeto. Conseguiu. Foi lá fazer o curso e trouxe para a gente e implantou na escola (Luciana. Profissional da escola).

Nós vimos no Fantastico, um professor daqui entrou em contato e fomos um grupo conhecer o projeto em São Sebastião. Aí a gente viu, sabe, os alunos dizendo que antes causavam muita confusão e que depois mudaram o comportamento (Mariana. Profissional da escola).

A reportagem, no entanto, não apresenta as diferenças então existentes na escola em São Sebastião, alvo da reportagem, na qual o "Projeto Estudar em Paz" era apenas um entre pelo menos 40 projetos, realizados em parcerias com embaixadas, ONGs, ministérios e universidade, que envolviam desde atividades artísticas (aulas de circo) a políticas (fóruns, discussões, oficinas). Na escola pesquisada isso não acontece:

Atualmente projetos fora do currículo não existem. É só aqueles que estão vivos na secretaria e aqueles que a escola trabalha, mas nada que parta de um professor e a escola trabalhe a partir disso. Atualmente não há nada nessa área (Cristóvão).

Não tem nada na escola. O ano todo assim teve tipo... Não teve nada, gente! Se teve um negócio foi uma feira de ciências. Não teve uma palestra, não foi trazido alguma coisa, coisas diferentes (Margarida. Estudante. Grupo focal).

[...] o CED São Francisco, era o que eu acho que desenvolvia mais ações. Eram muitos projetos que funcionavam lá, teve uma época que chegou a funcionar mais de quarenta projetos, de tudo quanto é área: eles tinham horta, costura, projeto de confecção de bonecos, de circo, de judô, de dança, de língua estrangeira. Nossa, era muita coisa: teatro, eles tinham o escola aberta, que fazia com que a escola funcionasse aos sábados com essas atividades, colônia de férias, acampamento... Então, eu acho que desenvolviam muitas ações que de uma forma, acho que direta, eles conseguiam lidar com essa questão da violência, profissionalizando, enfim, e fazendo, abrindo as portas da escola para a comunidade, pra tentar entender que comunidade era essa, quais que eram as demandas... Acabava fazendo a política da boa vizinhança! E [na escola pesquisada] eu realmente não me recordo de nada além de um projeto específico de uma professora que fazia a formação dos meninos em artes cênicas e eles chegaram até a apresentar uma peça em algum lugar. Mas pelo que eu me lembro essa professora também era contrato temporário. Então não era uma coisa da escola, era uma coisa dos professores (Letícia. Participante do Projeto).

Contudo, assim como anuncia Ortega e Del Rey (2002), um projeto de mediação de conflitos no contexto escolar vem complementar uma série de ações direcionadas a uma gestão democrática e participativa na escola, que impliquem, na realidade, numa efetiva transformação na escola e nos seus métodos institucionais. No entanto, na escola pesquisada, para os profissionais da escola a proposta seria mais uma ação de controle das ações dos estudantes, mas com a ausência de participação desses profissionais na transformação. A ideia era mesmo tentar controlar os estudantes como um "passe de mágica". 
Essa percepção pode ser observada a partir das dificuldades encontradas pelo "Projeto Estuda em Paz" durante a execução de suas atividades, mencionadas principalmente pelos estudantes e profissionais da escola descritos na Tabela 23.

Tabela 23- Dificuldades para a efetivação do Projeto

\begin{tabular}{|l|l|}
\hline \multicolumn{1}{|c|}{$\begin{array}{c}\text { Dificuldades do Projeto } \\
\text { Citadas pelos Estudantes }\end{array}$} & \multicolumn{1}{c|}{$\begin{array}{c}\text { Dificuldades do Projeto } \\
\text { Citada pelos Profissionais }\end{array}$} \\
\hline Falta de Espaço físico para a Mediação & Falta de espaço físico para a Mediação \\
\hline Falta de continuidade do Projeto & Falta de aceitação dos profissionais \\
\hline Falta de continuidade & Falta de continuidade do Projeto \\
\hline $\begin{array}{l}\text { Falta de horário específico para o curso de } \\
\text { Mediação }\end{array}$ & Falta de preparação dos profissionais \\
\hline
\end{tabular}

Fonte: Dados da Pesquisa

No discurso, os entrevistados, tanto profissionais quanto estudantes e membros da escola pesquisada, mencionaram a falta de espaço físico, a falta de continuidade das ações e a falta de preparação dos profissionais da escola como dificuldades na implantação e efetivação do "Projeto Estudar em Paz". Também foi mencionada a falta de aceitação por parte dos profissionais, o que já havia sido identificado em pesquisas anteriores realizadas por Gaspar (2012) e de Furtado (2011) bem como a falta de horário para a realização do curso de mediação.

É importante lembrar que os profissionais de uma escola têm um papel fundamental em toda e qualquer ação desenvolvida dentro de uma escola. Quando eles não aceitam, não consideram importante certa ação ou não acreditam na sua eficácia, tal ação corre o risco de fracassar. Não foi o que ocorreu com relação ao "Projeto Estudar em Paz" que teve um impacto positivo, pelo menos para os estudantes que dele participaram. No entanto, se houvesse maior engajamento de todos, principalmente dos profissionais, haveria a possibilidade de o "Projeto Estudar em Paz" apresentar resultados mais efetivos e se institucionalizar na escola pesquisa. O que não ocorreu.

Quanto ao fato de o "Projeto Estudar em Paz" ter trazido contribuição para seus participantes e (ou) para a escola, observou-se que todos os estudantes mencionaram contribuições positivas, enquanto nem todos os profissionais da escola perceberam tais contribuições. Entre estudantes e profissionais que as mencionam, elas teriam se dado na esfera pessoal dos participantes do curso de formação em mediação social.

A resistência dos professores ao "Projeto Estudar em Paz" parece fazer parte de um contexto que envolve a escola da atualidade. Sendo assim, não parece uma resistência que possa ser vencida com a simples alteração do programa do curso, tornando-o mais focado nos processos de resolução de conflito e menos na sensibilização. É uma resistência que vai permear a trajetória do "Projeto Estudar em Paz" enquanto ele atuar dentro do sistema de 
escolas públicas tradicionais buscando, sozinho, a transformação de estudantes, profissionais e da própria escola, transformação essa que pode ser compreendida como possível dentro de uma proposta de educação para os direitos humanos.

Além da relação entre profissionais também foi considerada dificuldade na implementação do "Projeto Estudar em Paz" a falta de espaço físico na escola para a realização da mediação. Nesse sentido, duas são as questões levantadas: a ausência de um espaço e de um horário específico para o curso e a ausência de uma sala para o núcleo de mediação.

Quanto à ausência de espaço e horário específico, o curso para os professores ocorreu dentro das atividades da "coordenação semanal", ou seja, reuniões administrativas da escola, com a reserva de $1 \mathrm{~h}$ semanal para o curso. No entanto, conforme já visto, não houve uma presença efetiva dos professores e as reuniões aconteciam em meio aos procedimentos normais da escola e aos atendimentos a estudantes.

Em relação ao curso ministrado a alunos e alunas, as aulas aconteciam nos horários livres ou no contra turno escolar, mas sem um espaço ou local específico:

Às vezes a gente chegava e não tinha sala para realizar as atividades, a sala estava ocupada, era uma sala improvisada (Júlia. Integrante do Projeto).

Algumas vezes não consegui dar a aula porque não tinha sala (Marta. Integrante do Projeto).

A gente não tinha sala, aí a gente vinha pra escola e ficava caçando um lugar. Tipo assim: a professora faltou, a gente ia lá pra sala da professora que faltou. No dia que professor não faltava, a gente ficava na sala ao lado do laboratório, ficava do lado de fora sentado no chão no pátio. Não tinha espaço (Ana. Estudante. Grupo Focal).

A pesquisa evidencia, assim, que o "Projeto Estudar em Paz" atuou dentro de uma precariedade que pode impactar sua implementação e seus resultados. Não havia uma sala destinada ao desenvolvimento de suas atividades, as quais iam acontecendo na medida em que aguardavam a disponibilidade de sala no dia.

Há aqui uma situação estrutural da escola: seus espaços são previamente definidos e pode se tornar complicado ou difícil estabelecer espaços próprios para projetos e atividades externas. Contudo, há também um processo que dificulta ainda mais essa situação: a falta de colaboração dos profissionais da escola. Nesse sentido, Letícia relata sua percepção:

A gente tinha o apoio formal, mas não tinha as condições necessárias para desenvolver o trabalho (Letícia. Participante do projeto).

Mais uma vez, o desenvolvimento de projetos no contexto escolar, quais forem, depende do apoio dos integrantes da própria escola e da própria instituição. No caso da escola pesquisada, havia um profissional responsável pelo desenvolvimento das atividades, mas que 
saíra em 2013, sem que houvesse outra pessoa para assumir. Essa situação demonstrou a dificuldade do "Projeto Estudar em Paz" em aproximar-se desses profissionais. O apoio de um único profissional pode não significar o apoio da escola:

Tudo era pessoal. Se a gente precisava de algo, o Marcos diretamente ia e fazia e a gente achava que isso era um contato com a escola! Mas isso não era um contato com a escola, era um contato com o Marcos (Letícia. Participante do Projeto).

No entanto, cabe lembrar ainda que foi mencionado pelos entrevistados que muitos alunos que fizeram o curso em anos anteriores saíram da escola para continuarem seus estudos em outras instituições, já que a escola é de ensino fundamental. Da mesma forma, alguns dos professores eram novos e outros haviam saído. Letícia, uma das participantes do Projeto, relatou, em entrevista, que essa era uma situação comum: terminava-se a formação de uma turma, e ela saía da escola; conseguia-se a sensibilização de professores e eles trocavam de escola, o que também pode ter interferido no desenvolvimento das atividades do "Projeto Estudar em Paz”, o que justificaria a dificuldade de continuidade: está sempre recomeçando suas atividades.

Diante dessa situação, a pesquisa de campo verificou que o "Projeto Estudar em Paz" não resolve ou extingue conflitos no contexto escolar, mas oferece uma alternativa para se lidar com eles de uma forma mais dialógica e democrática. Contudo, isso só será possível quando todos os atores escolares atuarem conjuntamente num processo que visa à transformação da escola.

Nesse sentido, o "Projeto Estudar em Paz" possui impactos positivos junto aos estudantes participantes do curso de formação de mediação. Contudo, encontra dificuldades de institucionalização: os profissionais da escola não atuam como parceiros do "Projeto Estudar em Paz". Essa dificuldade é encontrada também por seus membros, que não conseguiram estreitar relações com a escola. Como resultado, o "Projeto Estudar em Paz" enfrenta também dificuldades estruturais (ausência de espaço físico, de participação de professores) que impedem a expansão dos resultados positivos para além do grupo beneficiado, ou seja, para as pessoas que participaram desse projeto. Ainda assim, ele se apresenta como uma ferramenta de educação para os direitos humanos ao auxiliar na formação de sujeitos de direito, críticos e solidários com sua realidade. 


\section{CONCLUSÃO}

O projeto de extensão e ação contínua da Universidade de Brasília "Estudar em Paz: mediação de conflitos no contexto escolar" possui o condão de promover a transformação individual dos estudantes que dele participam no que se refere às formas de gerir os conflitos do cotidiano. Ele não diminui os conflitos no ambiente escolar, nem busca tal meta ao adotar uma visão positiva do conflito. Assim, ele propicia sensibilização aos seus participantes quanto à possibilidade de se lidar com tais conflitos de formas não violenta, favorecendo o diálogo e a convivência na pluralidade, atendendo aos pressupostos da mediação social.

Observou-se ainda que ele não atua diretamente junto às violências duras, mas junto às incivilidades nos conflitos inter pares e na conscientização das violências estrutural e simbólica. Tal conscientização desenvolve-se por meio do curso de formação em mediação social e por meio da realização de mediações coletivas, que têm o potencial de se transformar em instâncias de discussão sobre os problemas da escola, favorecendo, assim, a participação social.

Diante disso, a pesquisa evidenciou que o "Projeto Estudar em Paz" é uma ferramenta importante num processo de educação para os direitos humanos, ao auxiliar na formação de sujeitos de direitos.

Contudo, os benefícios do "Projeto Estudar em Paz" são notados apenas entre aqueles que participam do curso de formação que, conforme verificado junto à escola pesquisada, são principalmente estudantes. Dessa forma, não se evidenciaram, nesta pesquisa, impactos para além do grupo que passa pelo curso de formação e nem ações de multiplicação dos saberes adquiridos. Não há uma atuação efetiva junto aos profissionais da escola, à família ou demais membros da comunidade escolar, conforme originalmente previsto, da mesma forma como não há a efetivação de alguns objetivos reportados como essenciais para o próprio projeto, entre eles o mapeamento da rede de proteção e assistência social.

Traa-se de uma proposta de mediação por pares, ao contrário do enfoque global desejado. Isso significa que não há a transformação da escola.

Os motivos para tanto variam: vão desde o próprio planejamento da ação junto à escola atendida, que é sempre externo ao calendário escolar e não se integra como uma ação da escola, perpassando o não atendimento às expectativas dos profissionais da escola, ansiosos por um aporte técnico sobre como lidar com os conflitos em sala de aula, ou ainda pelas questões estruturais do próprio projeto, realizado dentro de uma ação militante. Nesse 
sentido, não se pode esquecer que é um projeto de extensão de uma universidade, sujeito às limitações inerentes a essa condição.

Tais dificuldades, no entanto, não são exclusivas do "Projeto Estudar em Paz". Pode-se considerar que as políticas públicas como um todo padecem de dificuldades de implementação e de avaliação, muitas das quais decorrentes da própria elaboração da política. Ao mesmo tempo, é preciso considerar que ele é externo à escola, mas que atua dentro dela e, nesse sentido, deve se adequar a uma instituição que possui um calendário próprio, atividades e cobranças que não incluem as demandas do projeto para sua realização. Isso aliado ainda às resistências apresentadas pela instituição como um todo.

Em relação às resistências, verificou-se que o "Projeto Estudar em Paz" vivencia uma permanente disputa com a própria instituição escolar e seus profissionais, de forma que a principal dificuldade encontrada é justamente a relação com esses profissionais que, em certa medida, atuam como atores de veto. A pesquisa evidenciou, assim, a importância de uma parceria efetiva com esses profissionais.

Um dos motivos para tanto é que o "Projeto Estudar em Paz", apesar de focar na mediação inter pares, possui um discurso de mudança da escola como um todo e de democratização das relações em geral. Nesse sentido, a mediação social é vista como uma forma de democratização das relações e de promoção da cidadania.

Dentro desse contexto, ele se depara com um conflito inerente a essa situação: a própria instituição escolar que, com seus fundamentos e suas expectativas, não busca sua própria transformação, mas apenas ações que facilitem seu controle sobre os alunos. Além disso, os profissionais da escola sentem que o "Projeto Estudar em Paz" não lhes oferece ferramentas práticas para lidar com os conflitos no contexto escolar. Ele oferece apenas uma sensibilização sobre as causas dos conflitos e sobre situações de violência.

Com isso, é necessária uma reflexão quanto às práticas estabelecidas, sobre os objetivos, as metas e os procedimentos, que permita a inserção efetiva do projeto nas escola e sua implementação para o maior número possível de estudantes. É importante também o cumprimento de todas as etapas a que ele se propõe (cursos de formação, inserção da mediação como prática disciplinar, mediação entre pares). É preciso, ainda, que se foquem os resultados, não só a curto e médio, mas também a longo prazo, conforme sugerem as pesquisas sobre o tema, mencionadas ao longo desse trabalho.

O redimensionamento das ações, no entanto, só será possível se o "Projeto Estudar em Paz" contar com um processo permanente de avaliação, pelo qual possa evidenciar o impacto das ações desenvolvidas e a necessidade ou não de replanejamento. 
Seja como for, a mediação de conflitos no contexto escolar é um tema muito recente no Brasil. São apenas 14 anos desde a primeira experiência registrada. O "Projeto Estudar em Paz", por sua vez, possui apenas cinco anos, sendo que, nas escolas atendidas, não passou ainda mais de três anos em nenhuma delas. Daí que a presente pesquisa não tem o condão de se fazer definitiva. Ao contrário, ela busca oferecer reflexões para que novas pesquisas sejam realizadas.

Aliás, esse é um campo de pesquisa que pode se mostrar promissor para os próximos anos considerando o recente Plano Nacional de Educação e a necessidade de ações que favoreçam a convivência escolar bem como a formação de uma cultura de direitos humanos. 


\section{RECOMENDAÇÕES}

Como forma de contribuir para o aperfeiçoamento do "Projeto Estudar em Paz”, esta pesquisa também procurou compreender, junto aos entrevistados, em que pontos ele precisaria melhorar e quais as sugestões para sua efetivação e alcance de resultados. Após a análise, tais sugestões foram classificadas em três grupos: junto à universidade, às escolas e ao poder público, conforme segue:

- Junto à universidade:

- implementar cursos de mediação de conflitos e mediação social no contexto escolar para aumentar a sensibilização acerca das diversas violências e sobre uma noção positiva do conflito escolar;

- implementar ações direcionadas à formação de professores e educadores, seja por meio de cursos de extensão, seja por meio de aulas, voltadas às técnicas de comunicação para se administrar conflitos em sala de aula;

- aprofundar a formação dos integrantes do "Projeto Estudar em Paz" no processo de mediação, suas técnicas e nas ações do extensão;

- melhorar a política de avaliação e divulgação de trabalhos desenvolvidos por meio da publicação de artigos ou congêneres no ambiente acadêmico.

- Junto à escola atendida:

- focar a atuação em, no máximo, duas escolas;

- buscar a atuação de longo prazo, no mínimo três anos, a fim de construir laços, sensibilizar e poder colher resultados mais consistentes;

- priorizar a formação dos adultos da escola e da comunidade, ao invés de focar apenas nos estudantes;

- buscar formar o maior número possível de estudantes, de todos os níveis educacionais, a fim de permitir resultados duradouros e permanentes;

- estabelecer a mediação de conflitos como prática disciplinar, realizada pelos adultos diante dos conflitos na escola;

- buscar a divulgação das ações dentro da escola;

- melhorar a comunicação entre os membros do "Projeto Estudar em Paz" e a escola como um todo. 
- Junto ao poder público:

- atuar junto a poder público para possibilitar a inclusão da mediação de conflitos às praticas e ações no contexto escolar, , influenciando, assim, nas políticas públicas;

- articular junto ao poder público para viabilizar a inclusão nos programas de formação dos profissionais escolares técnicas e modos de mediação de conflitos, em especial na formação continuada;

- realizar parcerias efetivas junto aos diversos órgãos e instituições que possam contribuir para o desenvolvimento das atividades do projeto. 


\section{REFERÊNCIAS BIBLIOGRÁFICAS}

ABRAMOVAY, Miriam et. al. Juventude, violência e vulnerabilidade social na América Latina: desafios para políticas públicas. Brasília: UNESCO, BID, 2002.

(org). Violência nas escolas: situação e perspectiva. Brasília: Boletim 21,

$2005 a$.

(coord). Cotidiano das escolas: entre violências. Brasília: UNESCO,

Observatório de Violência, Ministério da Educação, 2005.

et. al. Revelando tramas, descobrindo segredos: violência e convivência

nas escolas. Brasília: Rede de Informação Tecnológica Latino-americana - RITLA, Secretaria de Estado de Educação do Distrito Federal - SEEDF, 2009.

RUA, Maria das Graças. Violência nas escolas. Brasília: UNESCO, Coordenação DST/AIDS do Ministério da Saúde, Secretaria de Estado dos Direitos Humanos do Ministério da Justiça, CNPQ, Instituto Ayrton Senna, UNAIDS, Banco Mundial, USAID, Fundação Ford, CONSED, UNDIME, 2002.

ALMEIDA, Fábio Portela Lopes de. A teoria dos jogos: uma fundamentação teórica dos métodos de resolução de disputa. In: AZEVEDO, André Gomma de (org.). Estudos em Arbitragem, Mediação e Negociação, Brasília: Grupos de Pesquisa, vol 2, 2003, p. 175 2003.

ANUÁRIO DO DF 2013: uma ferramenta de fomento ao turismo e ao desenvolvimento do Distrito Federal. Brasília: Mark Comunicação, Ano 4, nº 1, set. 2013. Disponível em: < http://www.anuariododf.com.br/downloads/>. Acesso em 10 jun. 2014.

ARENDT, Hanna. As origens do totalitarismo: antissemitismo, imperialismo, totalitarismo. São Paulo: Companhia das Letras, 1989.

Da violência. S.L, 2004. Livro em formato digital. Disponível em <http://www.sabotagem.revolt.org>. Acesso em 30 abr. 2014.

A condição humana. 10 ed. Rio de Janeiro: Forense Universitária, 2005.

Entre o passado e o futuro. $7^{\text {a }}$ edição. São Paulo: Perspectiva, 2013.

ARISTÓTELES. Política. São Paulo: Nova Cultural, 1999.

ASSIS, Orly Zucatto Matovani. VINHA, Telma Pileggi. O processo de resolução dos conflitos interpessoais na escola autocrática e democrática. Revista IANE: Educação e Contemporaneidade, Bahia, n. 1, nov. 2003.

AZEVEDO, André Gomma de. Autocomposição e processos construtivos: Uma breve análise de projetos-piloto de mediação forense e alguns de seus resultados. In: AZEVEDO, André Gomma de (org.) Estudos em arbitragem, mediação e negociação. Brasília: Ed. Grupos de Pesquisa, v. 3, 2004, p. 137-150. 
Perspectivas metodológica s do processo de mediação: apontamentos sobre a autocomposição no direito processual. In: AZEVEDO, André Gomma de (org.). Estudos em Arbitragem, Mediação e Negociação, Brasília: Grupos de Pesquisa, v. 2, 2003, p. 151 172.

AZEVEDO, Fernando de. Sistemas escolares. In: PEREIRA, Luiz. FORACCHI, Marialice M. Educação e Sociedade. 8 ed. São Paulo: Ed. Nacional, 1977, p. 138 - 148.

BARBOSA, A. A. Composição da historiografia da mediação - instrumento para o direito de família contemporâneo. Direitos culturais, no. 3, vol. 2, dez. 2007, p. 11- 21. Santo Ângelo, R. S: Universidade Regional Integrada. Disponível em:

$<$ http://srvapp2s.urisan.tche.br/seer/index.php/direitosculturais/article/view/94/74>. Acesso em: 13 abr. 2013.

BASTOS, Maria Helena Câmara. A instrução pública e o ensino mútuo no Brasil: uma história pouco conhecida (1808-1827). História da Educação. Pelotas, RS:

ASPHE/FAE/UFPEL, n. 01, abr, 1997, p. 115 - 133,

BAUER, M. W. Análise de Conteúdo clássica: uma revisão. In: BAUER, M. W. e GASKELL, G. (org). Pesquisa qualitativa com texto, imagem e som: um manual prático. Petrópolis: Vozes, 2003, p. 189 - 215.

BECKER, Howard. A escola de Chicago. Mana. Vol. 02, n. 02. Rio de Janeiro: Programa de Pós-Graduação em Antropologia Social - PPGAS-Museu Nacional. Universidade Federal do Rio de Janeiro - UFRJ. 1996, p. 177-188. Disponível em: < http://dx.doi.org/10.1590/S010493131996000200008>. Acesso em 25 jul. 2013.

BELEZA, Flávia T. Estudar em paz: Mediação de conflitos no contexto escolar.

Participação. Brasília: DEX. Ano 12, n. 22, dez. 2012, p. 52 - 59. Disponível em: $<$ http://seer.bce.unb.br/index.php/participacao/article/view/6323/5902>. Acesso em 24 out. 2014.

BELL, J. Como realizar um projecto de investigação: um guia para a pesquisa em ciências sociais e da educação. 3 ed., Lisboa: Gradiva, 2004.

BERGER, Peter L. BERGER, Brigitte. O que é uma instituição social? In: FORACCHI, Marialice Mencarini. MARTIN, José de Souza (org). Sociologia e sociedade: leituras de introdução à Sociologia. Rio de Janeiro: Livro Técnico e Científico, 1980. p. 193 - 199.

. BERGER, Brigitte. Socialização: como ser um membro da sociedade. In: FORACCHI, Marialice Mencarini. MARTIN, José de Souza (org). Sociologia e sociedade: leituras de introdução à Sociologia. Rio de Janeiro: Livro Técnico e Científico, 1980a. p. 200 $-214$.

Petrópolis: Vozes, 1976.

LUCKMANN, Thomas. A construção social da realidade. $3^{\mathrm{a}}$. ed.

BITTAR, Eduardo C. B. Educação e metodologia para os direitos humanos: cultura democrática, autonomia e ensino jurídico. In: SILVEIRA, Rosa Maria Godoy (org). 
Educação em direitos humanos: fundamentos teórico-metodológicos. João Pessoa: Editora Universitária, 2007, p. 313 - 334.

BLACKBURN, Simon. Dicionário Oxford de filosofia. Rio de Janeiro: Jose Zahar, 1997.

BORGES, André. Desenvolvendo argumentos teóricos a partir de estudos de caso: o debate recente em torno da pesquisa histórico-comparativa. Revista BIB, n. 63, 2007, p. 47-62.

BOURDIEU, Pierre. O pode simbólico. Rio de Janeiro: Bertrand Brasil, 1989.

PASSERON, Jean Claude. A reprodução. Elementos para uma teoria do sistema de ensino. Rio de Janeiro: Francisco Alves, 1975.

BRADLEY, S. SMITH, M. Community Mediation: Reflections on a Quarter Century of Practice. Mediation Quarterly, vol. 17, no. 4, 2000, p. 315-320.

BRASIL, Constituição da República Federativa do Brasil de 1988: promulgada em 5 de outubro de 1988 com alterações até a Emenda n. 82, de 16 de julho de 2014. Disponível em: <http://www.planalto.gov.br/ccivil_03/constituicao/constituicaocompilado.htm>. Acesso em 5 ago de 2014.

Decreto-lei n. 1.572, de 28 de julho de 1995, que regulamenta a mediação na negociação coletiva de natureza trabalhista e dá outra providências. Diário Oficial da União de 31 de julho de 1995. Disponível em: < http://www.planalto.gov.br/ccivil_03/decreto/1995/D1572.htm>. Acesso em 15 jul. 2014.

Lei no. 10.101, de 19 de dezembro de 2000, que dispõe sobre a participação dos trabalhadores nos lucros ou resultados da empresa e dá outras providências. Diário Oficial da União de 20 de dezembro de 2000. Disponível em: < http://www.planalto.gov.br/ccivil_03/leis/110101.htm>; Acesso em 15 jul. 2014.

Plano Nacional de Educação em Direitos Humanos. Comitê Nacional de Educação em Direitos Humanos. Brasília: Secretaria Especial dos Direitos Humanos, Ministério da Educação, Ministério da Justiça, UNESCO, 2007.

Ministério do Planejamento, Orçamento e Gestão. Instituto Brasileiro de Geografia e Estatística. Síntese de Indicadores Sociais: uma análise das condições de vida da população brasileira. Rio de Janeiro, 2009. Disponível em:

<http://www.ibge.gov.br/home/estatistica/populacao/condicaodevida/indicadoresminimos/sint eseindicsociais2009/indic_sociais2009.pdf.> Acesso em 20 mai 2013.

Ministério da Justiça. Ministério da Justiça promove oficina de mídia e cidadania: Ministério da Justiça estimula a cidadania entre jovens. In: FIGUEIREDO, Gisele. Radio Agencia Nacional. 23 jan. 2009a. Disponível em: <http://radioagencianacional.ebc.com.br/node/96105>. Acesso em 11 nov. 2013.

Decreto n. 7416, de 30 de dezembro de 2010, que regulamenta os artigos 10 e 12 da Lei no 12.155 , de 23 de dezembro de 2009, que tratam da concessão de bolsas para desenvolvimento de atividades de ensino e extensão universitária. Diário Oficial da União. Brasília, DF, n. 251, 31 dez. 2010. Seção 1, p. 12 - 13. Disponível em: 
$<$ http://pesquisa.in.gov.br/imprensa/jsp/visualiza/index.jsp?data=31/12/2010\&jornal=1\&pagi na $=13 \&$ totalArquivos=168>. Acesso em 6 jun. 2014.

Programa Nacional de Direitos Humanos (PNDH-3). Secretaria Especial dos Direitos Humanos da Presidência da República. Brasília: SEDH/PR, 2010.

A disciplina nas escolas está deteriorada? In: PISA em foco. Instituto Nacional de Estudos e Pesquisas Educacionais Anísio Teixeira, 2011. Disponível em: < http://download.inep.gov.br/acoes_internacionais/pisa/pisa_em_foco/2011/pisa_em_foco_n4. pdf>. Acesso 25 jun. 2014.

Relatório Nacional PISA 2012: Resultados brasileiros. Instituto Nacional de Estudos e Pesquisas Educacionais Anísio Teixeira, 2012. Disponível em: < http://download.inep.gov.br/acoes_internacionais/pisa/resultados/2014/relatorio_nacional_pis a_2012_resultados_brasileiros.pdf $>$. Acesso em 26 jun. 2014.

, Pesquisa Nacional de Saúde Escolar 2012. Rio de Janeiro: Instituto

Brasileiro de Geografia e Estatística, 2013. Disponível em: <

http://portalsaude.saude.gov.br/portalsaude/arquivos/pdf/2013/Jun/20/pense_2012_arquivo_w eb.pdf>. Acesso em 24 out. 2013.

Data Escola Brasil. Instituto Nacional de Estudos e Pesquisas Educacionais Anísio Teixeira, 2013a. Disponível em: < http://www.dataescolabrasil.inep.gov.br/dataEscolaBrasil/home.seam>. Acesso em 26 jun. 2014.

Lei n. 13.005, de 25 de junho de 2014. Estabelece o Plano Nacional de Educação. Publicado no Diário Oficial da União, Seção 1, Edição Extra, 26 de junho de 2014, p. 01. Disponível em: <

http://pesquisa.in.gov.br/imprensa/jsp/visualiza/index.jsp?jornal $=1000 \&$ pagina $=1 \&$ data $=26 / 0$ 6/2014>. Acesso em 20 ago. 2014.

BROWN, Daniel G. Divorce and Family Mediation: History, Review, Future Directions. Conciliation Courts Review, n. 20, v. 2, 1982, p. 1-37. Disponível em: <http://onlinelibrary.wiley.com/doi/10.1111/j.174-1617.1982.tb00086.x/abstract>. Acesso 15 jun 2014.

BUENO, André. A resposta de Confúcio ao problema dos direitos humanos. Crítica. 2004. Disponível em: <http://criticanarede.com/etic_confucio.html>. Acesso 25 jul. 2014.

BUENO, Samira. LIMA, Renato Sérgio de. A opaca estética da indiferença: letalidade policial e políticas públicas de segurança. In: $5^{\circ}$ Relatório Nacional sobre os Direitos Humanos no Brasil, 2001 - 2010. São Paulo: Núcleo de Estudos da Violência da Universidade de São Paulo, 2012, p. 104 - 110. Disponível em: < http://www.nevusp.org/downloads/down265.pdf\#page=106>. Acesso 25 jul. 2014.

BUSH, R. A. B. FOLGER, J. P. The promise of mediation: the transformative approach to conflict. San Francisco: Jossey-Bass A Wiley Imprint, 2005. 
CANDAU, Vera Maria. Educação em Direitos Humanos: desafios atuais. In: SILVEIRA, Rosa Maria Godoy (org). Educação em direitos humanos: fundamentos teóricometodológicos. João Pessoa: Editora Universitária, 2007, p. 399 - 412.

CANDIDO, Antônio. A estrutura da escola. In: PEREIRA, Luiz. FORACCHI, Marialice M. Educação e Sociedade. 8 ed. São Paulo: Ed. Nacional, 1977, p. 107 - 128.

CANELLAS, Marcelo. Professores resolvem conflito no DF na base da conversa. Fantástico. Rio de Janeiro: TV Globo ltda, 19 de setembro de 2011. Video Youtube. 6Min16s, son, col. Disponivel em: <https://www.youtube.com/watch?v=DzGWD9xiQdM>. Acesso em 24 abr. 2014.

CANNES, Michele. Mediação resolve conflitos em escola. Youtube. Brasília. CNTE TV, 24 nov. 2010. Vídeo Youtube. 5min52seg, son, col. Disponível em:

<http://www.youtube.com/watch?v=4CAJ9ZgByWY>. Acesso em 6 jun. 2014.

CARBONARI, Paulo César. Sujeito de direitos humanos: questões abertas e em construção. In: SILVEIRA, Rosa Maria Godoy et al. (org). Educação em direitos humanos:

fundamentos teórico-metodológicos. João Pessoa: Editora Universitária, 2007, p. 169-185.

CARNEIRO, Y. G. Mediação social no contexto escolar: o Reconhecimento do Conflito e o Enfrentamento à Violência em uma Escola Classe do DF. [monografia de conclusão de curso de Bacharel em Serviço Social]. Brasília: Departamento de Serviço Social. Instituto de Ciências Humanas, Universidade de Brasília, 2014.

CARTILHA DE MEDIADORES: Como montar este Projeto na minha Escola? Projeto Escola de Mediadores. Viva Rio, Instituto NOOS, Mediare, 2002. Disponível em: < http://www.cnmp.mp.br/conteate10/pdfs/tema4_cartilha-mediadores.pdf >. Acesso 13 out. 2013.

CASTORIADIS, Cornelius. Teoria e Projeto Revolucionário. In: A instituição imaginária da sociedade. 5. Ed. Rio de Janeiro: Paz e Terra, 1982.

CHARLOT, B. A violência na escola: como os sociólogos franceses abordam esta questão. Sociologias, Porto Alegre, ano 4, $\mathrm{n}^{\circ}$ 8, jul/dez 2002, p. 432-443. Disponível em: <http://www.scielo.br/pdf/soc/n8/n8a16.pdf> Acesso em: 24. jun. 2011.

CHAUVET, Eduardo. Pautas positivas da educação pública no Distrito Federal. Programa Alternativo. Brasília: Sindicato dos Professores do DF Sinpro DF. Sistema Brasileiro de Televisão - SBT, 17 nov. 2012. Vídeo Youtube. 3min12seg, son, col. Disponível em: <https://www.youtube.com/watch?v=RYo6OYEixHE>. Acesso 6 jun. 2014.

Projeto ajuda alunos e professores no combate à violência. Programa Alternativo. Brasília: Sindicato dos Professores do DF Sinpro DF. Sistema Brasileiro de Televisão - SBT, 15 out. 2011. Vídeo Youtube. 3min, son, col. Disponível em: <http://www.youtube.com/watch?v=b_ymNKISp-U>. Acesso 6 jun. 2014.

CLASTRES, Pierre. Arqueologia da violência - pesquisas de antropologia política. São Paulo: Editora Cosac \& Naify, 2004. 
CLAUDE, Richard Pierre. Direito à educação e educação para os direitos humanos. SUR Revista Internacional de Direitos Humanos, ano 2, n. 2, 2005, p. 37 a 64. São Paulo: SUR - Rede Universitária de Direitos Humanos. Disponível em: <

http://conectas.org/Arquivos/edicao/pdfs/edicao-2014210151639827-

25554542.pdf\#page=37>. Acesso em 5 jul. 2014.

COHÉN, Jerome Alan. Chinese Mediation on the Eve of Modemization. California Law Review, n. 54, v. 2, 1966, p. 1201-1226. Disponível em

$<$ http://scholarship.law.berkeley.edu/cgi/viewcontent.cgi $?$ article $=2913 \&$ context=californialaw review>. Acesso em 15 jun. 2014.

COMMUNITIY BOARDS. Building Community Through Conflict Resolution.

Disponível em: <http://communityboards.org/>. Acesso 14 jun. 2014.

COSTA, Alexandre Araújo. Cartografia dos métodos de composição de conflitos. In: AZEVEDO, André Gomma de (org.). Estudos em Arbitragem, Mediação e Negociação, Ed. Brasília: Grupos de Pesquisa, vol. 2, 2003, p. 161-201.

COSTA, M. E. B. Grupo Focal. In: DUARTE, J. BARROS, A. (org). Métodos e técnicas de pesquisa em comunicação. São Paulo: editora Atlas, 2005, p. 180-192.

COULANGES, Numa Denis Fustel. A cidade antiga. Edameris: São Paulo, 1961.

CRAWFORD, Donna. BODINE, Richard. Conflict Resolution Education A Guide to Implementing Programs in Schools, Youth-Serving Organizations, and Community and Juvenile Justice Settings. S.L. Office of Juvenille Justice and Delinquency Prevention. US Department of Justice. Safe and Drugs Schools Programs. Us Department of Education, October, 1996.

DAMIANI, M. F. Entendendo o trabalho colaborativo em educação e entendendo seus benefícios. Educar, n. 31, 2008, p. 213-230. Curitiba: Editora UFPR.

<http://www.scielo.br/pdf/er/n31/n31a13>. Acesso em 15 jul. 2014.

DEBARBIEUX, Eric. Violência na escola: um desafio mundial? Lisboa: Instituto Piaget, 2006.

UNESCO, 2002.

BLAYA, Catherine. Violência nas Escolas e Políticas Públicas, Brasília:

. Violência nas escolas: dez abordagens europeias. Brasília: UNESCO,

2002a.

DEMO, P. Metodologia científica em ciências sociais. 3 ed. São Paulo: Atlas, 1995.

DEUTSCH, Morton. A resolução do conflito. In: AZEVEDO, André Gomma (org). Estudos em arbitragem, mediação e negociação. Brasília: Ed. Grupos de Pesquisa, v. 3, 2004, p. 29 40 . 
DICIONÁRIO Etimológico. 2012. Disponível em:

$<$ http://www.dicionarioetimologico.com.br/searchController.do?hidArtigo=AE32AE4CB655 32B3804583B9D0BCDDF7>. Acesso em 7 jul. 2014.

DIEESE. Relatório Analítico Final da Pesquisa Socioeconômica em Territórios de Vulnerabilidade Social no Distrito Federal. Brasília, fev. 2011. Disponível em: $<$ http://www.dieese.org.br/dieese/projetos/SEDEST/pesquisaSocioeconomicaSEDEST/produt o6.pdf>. Acesso em 13 abr. 2014.

DISTRITO FEDERAL. Pesquisa distrital por amostra de domicílios 2013. Brasília: CODEPLAN - Companhia de Planejamento do Distrito Federal. Janeiro de 2013. Disponível em: <http://www.codeplan.df.gov.br/component/content/article/261-pesquisassocioeconomicas/294-pdad-2013.html>. Acesso em 10 jun. 2014.

Plano de (com)vivência escolar: construção em rede. Distrito Federal: Secretaria de Estado de Educação, Subsecretaria de Educação Básica, 2012.

Polícia Civil do Distrito Federal. Divisão de Estatística e Planejamento Operacional. Relatório Anual da Criminalidade do DF. 2010a. Disponível em: http://www.pcdf.df.gov.br/pgAnaliseTematica.aspx. Acesso em 13 de junho de 2014.

. Polícia Civil do Distrito Federal. Divisão de Estatística e Planejamento Operacional. Relatório Anual da Criminalidade do DF. 2011. Disponível em: http://www.pcdf.df.gov.br/pgAnaliseTematica.aspx. Acesso em 13 de junho de 2014.

Polícia Civil do Distrito Federal. Divisão de Estatística e Planejamento Operacional. Relatório Anual da Criminalidade do DF. 2012a. Disponível em: http://www.pcdf.df.gov.br/pgAnaliseTematica.aspx. Acesso em 13 de junho de 2014.

População e Renda per capita (mensal) das Regiões Administrativas do Distrito Federal e dos Municípios de sua Área Metropolitana. Brasília: Companhia de Planejamento do Distrito Federal, 2010. Disponível em: http://www.codeplan.df.gov.br/images/CODEPLAN/PDF/Pesquisas\%20Socioecon\%C3\%B4 micas/TABELA\%20RENDA\%20PER\%20CAPITA\%20E\%20POPULA\%C3\%87\%C3\%830 \%20-\%20CENSO\%202010.pdf. Acesso em 10 de junho de 2012.

Cadastro das Instituições Educacionais Estaduais - por "RA" - Censo

Escolar 2013 por modalidade. Brasília: Secretaria de Estado de Educação, 2013a.

Disponível em:

<http://www.cre.se.df.gov.br/ascom/documentos/censo/2013/cadastro_instituicoes_completo_ 2013_mar14.pdf>. Acesso em 6 jun. 2014.

DRAWIN, Carlos Roberto. O paradoxo antropológico da violência. In: ROSÁRIO, Angela Buciano do; NETO, Fuad Kyrillos; MOREIRA, Jacqueline de Oliveira (org.). Faces da violência na contemporaneidade: sociedade e clínica. Barbacena, MG: EdUEMG, 2011, p. $12-32$.

DURKHEIM, Émile. A educação como processo socializador: função homogeneizadora e função diferenciadora. In: PEREIRA, Luiz. FORACCHI, Marialice M. Educação e Sociedade. 8 ed. São Paulo: Ed. Nacional, 1977, p. 34 - 48. 
ENTELMAN, Remo F. Teoria do conflicto: Hacia un nuevo paradigma. Barcelona: Ed. Gedisa, 2002.

Escola em São Sebastião oferece mais de 40 atividades. Correio Braziliense. Brasília: Diários Associados, 13 mai. 2011. Disponível em:

<http://www.correiobraziliense.com.br/app/noticia/cidades/2011/05/13/interna_cidadesdf,252 003/escola-em-sao-sebastiao-oferece-mais-de-40-atividades-interdisciplinares.shtml >. Acesso em 7 jun. 2014.

ESTUDAR EM PAZ. Estudar em Paz. Enviado em 3 mai. 2010. Vídeo Youtube. 7min16seg, son, col. Disponível em: <http://www.youtube.com/watch?v=V2H-iAdr5-E >. Acesso em 10 jun. 2014.

Projeto Estudar em Paz - vídeo 3 - Inclusão - Alunos com necessidades especiais. Enviado em 10 fev. 2012. Vídeo Youtube. $7 \mathrm{~min} 36 \mathrm{seg}$, son., col. Disponível em: <http://www.youtube.com/watch?v=m3s9bvCCh20>. Acesso em 10 jun. 2014.

Projeto Estudar em Paz - vídeo 4. Aceitação das diferenças: as diversas tribos e a convivência no espaço escolar. Enviado em 10 fev. 2012a. Vídeo Youtube. $9 \mathrm{~min} 4 \mathrm{seg}$, son, col. Disponível em: < http://www.youtube.com/watch?v=1_vIme8JFYs >. Acesso em 10 jun. 2014.

Projeto Estudar em Paz - vídeo 5. Conhecendo a mediação. Enviado em 10 fev. 2012b. Vídeo Youtube. 8min10seg, son, col. Disponível em: < https://www.youtube.com/watch?v=abKMUidpCBk>. Acesso em 10 jun. 2014.

Projeto Estudar em Paz - vídeo 6. A arte da mediação. Enviado em 10 fev. 2012c. Vídeo Youtube. 3min12seg, son, col. Disponível em: < https://www.youtube.com/watch?v=ulgWTVsWwyw>. Acesso em 10 de jun. 2014.

FERREIRA, Ana Laura Carneiro Gomes. SOUZA, Ariani Impieri de. Aspectos éticos nas pesquisas com adolescentes. Revista Bioética n. 20, 2012, p. 56 - 59. Disponível em: $<$ http://revistabioetica.cfm.org.br/index.php/revista_bioetica/article/view/599/736>. Acesso em 6 jun. 2014.

FINN, Mary. Quaker education. In: BARBOUR, Hugh et al.. Quacker Crosscurrents three hundred years of friends in th New York. New York: New York Early Meeting of the Religious Society of Friends, 1995, p. $146-164$.

FISCHER, Rosa Maria (coord). Bullying escolar no Brasil: relatório final. São Paulo: Centro de Empreendedorismo Social e Administração em Terceiro Setor (CEATS) e Fundação Instituto de Administração (FIA), 2010.

FOCAULT, Michel. Microfísica do Poder. Rio de Janeiro: Graal, 1984.

Vigiar e punir: nascimento da prisão. Petrópolis, Vozes, 1999.

FRANCE, Médiation sociale et nouveaux modes de résolution des conflits de la vie quotidienne. Rencontres nationales des acteurs de la ville. Paris - Créteil: Les éditions de la 
DIV, 21 - 23, septembre, 2000. Disponível em: < http://www.ville.gouv.fr/?paris-creteil-2122-23-septembre>. Acesso em 15 de julho de 2014.

Evaluation de l'utilité sociale de cinq structures de médiation sociale:

rapport final. Paris: Ministère du Logement et de la Ville. 2008. Disponível em: < http://www.francemediation.fr/images/lang/fr/orki/doc00007-

Rapport_Final_Evaluation_de_1_utilite_sociale_de_la_mediation_sociale(3).pdf $>$. Acesso em 25 jun. 2013.

Guide d'évaluation de l'utilité sociale de la médiation sociale: Guide Méthodologique. Paris: Les Éditions du CIV, Set. 2009. Disponível em: < http://www.ville.gouv.fr/IMG/pdf/GuideSGCIV_EvaluationMediation.pdf>. Acesso em 25 jun. 2013.

. Mèdiation Sociale. In: Ministère délégue à la Ville. 2012 Disponível em: <http://www.ville.gouv.fr/?mediation-sociale,1715>. Acesso 06 set. 2013.

Médiation sociale: pour la reconnaissance dún métier. Rapport du groupe de travail. Paris: Les Éditions du CIV, Décembre, 2011. Disponível em: <http://www.ville.gouv.fr/IMG/pdf/sgciv-ouvragemediationsociale.pdf>. Acesso 25 jun 2013.

FREIRE, Paulo. Educação como prática de liberdade. Rio de Janeiro: Paz e Terra, 1967. Pedagogia do oprimido. 17a edição. Rio Janeiro, Paz e Terra: 1987.

Pedagogia da autonomia - saberes necessários à prática educativa. São Paulo: Paz e Terra, 1996.

Direitos Humanos e Educação Libertadora. In: FREIRE, Ana Maria Araújo (Org.). Pedagogia dos sonhos possíveis. São Paulo: UNESP, 2001.

FURTADO, Daniella Ovidio. Estudar em paz: uma experiência de mediação de conflitos no contexto escolar. 2011. 67 f. Monografia (Bacharelado em Serviço Social)-Universidade de Brasília, Brasília, 2011. Disponível em: 〈http://bdm.bce.unb.br/handle/10483/3660>. Acesso em 26 nov. 2012

GALTUNG, Johan. Cultural Violence. In: Journal of Peace Research, vol. 27, n. 3, 1990, p. 291-305.

Direitos Humanos uma nova perspectiva. Lisboa: Instituto Piaget, 1998.

O caminho é a meta: Gandhi hoje. São Paulo: Palas Atenas, 2003.

. Violence, Peace and Peace Research. In: Journal of Peace Research, vol. 06, n. 3, 1969, p.167 - 191.

GASPAR, Vânia Maria. O. Estratégias escolares no combate à violência: a mediação em uma escola de São Sebastião - DF. Universidade Católica de Brasília, 2012 [dissertação de mestrado]. Disponível em: 
<http://www.bdtd.ucb.br/tede/tde_busca/arquivo.php?codArquivo=1609>. Acesso em 21 dez. 2012.

GENTILI, Pablo A.A Adeus à escola pública: a desordem neoliberal, a violência do mercado e o destino da educação das maiorias. In: GENTILI, Pablo A.A. (org). Pedagogia da exclusão: crítica ao neoliberalismo em educação. 16 ed. Petrópolis: Vozes, 2009a, p. 215 237.

O discurso da 'qualidade' como nova retórica conservadora no campo educacional. In: GENTILI, Pablo A.A. SILVA, Tomaz Tadeu da. Neoliberalismo, qualidade total e educação - visões críticas. $6^{\mathrm{A}}$ edição. Petrópolis: Vozes, 1998, p. 111 - 179.

. Por uma Pedagogia da Esperança para Além do Desencanto. In: GENTILI, Pablo A.A. McCOWAN, Tristan (org). Reinventar a escola pública: política educacional para um novo Brasil. Petrópolis: Vozes, 2003, p. 257 - 272.

O direito à educação e as dinâmicas de exclusão na América latina.

Educação e Sociedade [on line], Campinas, vol. 30, n. 109, p. 1059-1079, set. - dez. 2009. Disponível em <http://www.scielo.br/scielo.php?script=sci_arttext\&pid=S010173302009000400007> Acesso em 02 abr. 2014.

GIL, A. C. Métodos e técnicas de pesquisa social. São Paulo: Atlas, 2012.

GINSBERG, R. B. American Bar Association Delegation Visits The People's Republic of China American Bar Association Journal, n. 64, 1978, p. 1516-1525. Disponível em: < http://books.google.com.br/books?id=iEQqF5M43DoC\&pg=PA1516\&lpg=PA1516\&dq=Am erican+Bar+Association+Delegation+Visits+The+People\%27s+Republic+of++China+ginsbe rg\&source=bl\&ots=zN3ReVWT6- $\&$ sig $=$ mN2wHW4my6PkrSN1RO2fpuOg7Ec\&hl=pt-

$\mathrm{BR} \& \mathrm{sa}=\mathrm{X} \& \mathrm{ei}=\mathrm{IQbLU} \_\mathrm{PlOeHj}$ AThy4LACQ\&ved=0CBwQ6AEwAA\#v=onepage\&q=Amer ican\%20Bar\%20Association\%20Delegation\%20Visits\%20The\%20People's\%20Republic\%20 of\%20\%20China\%20ginsberg\&f=false>. Acesso 15 jul. 2014.

GRIBBLE, James. Introduction to philosophy of education. Boston: Allyn and Bacon, 1970.

HALL, Stuart. A identidade cultural na pós-modernidade. 11 ed. Rio de Janeiro: DP\&A Editora, 2006.

HARRIS, Kevin. Education and knowledge. London: Routledge \& Kegan Paul, 1979.

HEGEL, George W.F. Crítica Moderna. In: SOUZA, José Cavalcante de (org). Os présocráticos - fragmentos, doxografia e comentários. São Paulo: Nova Cultural, 1999, p. 102 a 116.

HEREDIA, Ramón Alzate Saez. Enfoque global de la escuela como marco de aplicacion de los programas de resolución de conflitos. In: BRANDONI, Florência (coord.). Mediación escolar: ensaios y experiências. Buenos Aires: Paidos, 1999. 
La mediación escolar: processo colaborativo de la educación en resolución de conflictos. Trabajo social hoy. Madrid: Colégio Oficial de Diplomados enTrabajo Social y Asistentes Sociales de Madrid, $1^{\circ}$ semestre 2006, p. 73 - 96.

Programas de convivência em el âmbito educativo: enfoque global de transformación de conflictos y mediación escolar. In: Revista Proyecto. Madrid: Asociación Proyecto Hombre, n. 66, 2008, p. 15-18.

Resolución de conflictos en la escuela. In: BRADONI, Florência (coord).

Mediación escolar: ensaios y experiencias, Buenos Aires: Noveduc e Editorial Cep, n. 24, abril de 2009, p. 44-63.

HERNÀNDEZ-TRUYOL, Berta. GLEASON, Christy. Introduction. In: B. Hernández-Truyol (org.). Moral imperialism. A critical anthology. Nova York: New York University Press. p. 1- 18, 2002.

HERRERA FLORES, Joaquín. A (re) invenção dos direitos humanos. Florianópolis: Fundação Boiteux, 2009.

HERSCOVITZ, H. G. Análise de conteúdo em jornalismo. In: LAGO, C. BENETTI, M. (org) Metodologia de pesquisa em jornalismo. Petrópolis: Vozes, 2007, p. 123 - 142.

HOUAISS, A. VILLAR, M. de S.; FRANCO, F. M. M. Dicionário Houaiss da língua portuguesa. Rio de Janeiro: Objetiva, 2001.

ILLICH, Ivan. Sociedades sem escolas. $7^{\text {a }}$ edição. Petrópolis: Vozes, 1985.

JAGER, Márcia et al. Ética em pesquisa com adolescentes: uma revisão da literatura nacional. Revista Psicologia em Foco, v. 05, n. 05, jul 2013, p. 134-149. Disponível em: <http://revistas.fw.uri.br/index.php/psicologiaemfoco/article/view/1107/1583>. Acesso em 6 jun. 2014.

JARES, Xesús R. Educação para a paz: sua teoria e sua prática. Porto Alegre: Artmed, 2002.

Educar para a paz em tempos difíceis. São Paulo: Palas Athena, 2007.

Pedagogia da convivência. São Paulo: Palas Athena, 2008.

JELIN, Elizabeth. Cidadania revisitada: solidariedade, responsabilidade e direitos. In: JELIN, Elizabeth. HERSHEBERG, Eric. Construindo a democracia: direitos humanos, cidadania e sociedade na América Latina. São Paulo: Editora Universidade de São Paulo: Núcleo de Estudos da Violência (NEV), 2006, p. 155-179.

KOEHLER. Sonia Maria Ferreira. Violência psicológica: um estudo do fenômeno na relação professor- aluno. La nueva alfabetización: un reto para la educación del siglo XXI.

Disponível em: <http://www.educacao.salvador.ba.gov.br/site/documentos/espacovirtual/espaco-praxis-pedagogicas/RELA\%C3\%87\%C3\%830\%20PROFESSORALUNO/violencia\%20psicologica\%20- 
$\% 20$ um $\% 20$ estudo $\% 20 \mathrm{do} \% 20$ fenomeno $\% 20$ na $\% 20$ relacao $\% 20$ professor-aluno.pdf $>$. Acesso em 25 jul. 2014

KOWARICK, Lúcio. Sobre a vulnerabilidade socioeconômica e civil: Estados Unidos, França e Brasil. Revista Brasileira de Ciências Sociais, vol. 18, nº. 51, fev. 2003, p. 60 - 86.

Disponível em: <http://www.scielo.br/pdf/rbcsoc/v18n51/15986.pdf>. Acesso 23 jun. 2013.

LACERDA, João Bosco. Projeto Mediação Social da escola. Zapping Unb TV. Brasília: UNBTV, 13 dez. 2012. Vídeo Youtube. 7min47seg, son, col. Disponível em: <https://www.youtube.com/watch?v=jSN0xStS1E4>. Acesso em 7 jun. 2014.

LAGE, Maria Campos. Utilização do software NVivo em pesquisa qualitativa: uma experiência em EaD. ETD - Educ. Tem. Dig., Campinas, v.12, n.esp., p.198-226, mar. 2011. Disponível em:

<http://www.fae.unicamp.br/revista/index.php/etd/article/viewFile/2313/pdf_57>. Acesso em 14 abr. 2014.

LAO-TZU. Tao-te king: o livro do sentido e da vida. Texto e comentário de Richard Wilhelm. São Paulo: Pensamento, 1995.

LEFORT, Claude. A invenção democrática: limites da dominação totalitária. 2 Ed. São Paulo: 1987.

de Janeiro, Paz e Terra, 1991.

Pensando o político: ensaios sobre democracia, revolução e liberdade. Rio

LISBOA, Ângela Maria Patrício. A Pobreza, um Livre Trânsito para a Delinquência Juvenil? 303 fls. [Tese em Sociologia Econômica e das Organizações]. Lisboa: Universidade Técnica de Lisboa. Instituto Superior de Economia e Gestão, 2008. Disponível em: < https://www.repository.utl.pt/bitstream/10400.5/757/1/Angela,\%20tese,reformdefinit\%202.pd f>. Acesso em 25 jul. 2013.

LOCHE, Adriana. A letalidade da ação policial: parâmetros para análise. Tomo. Revista do programa de pós-graduação e Pesquisa em Sociologia. Sergipe: Universidade Federal, n. 17, jul-dez., 2010, p. 39 - 56. Disponível em: <

http://seer.ufs.br/index.php/tomo/article/view/507/423>. Acesso 25 jul. 2014.

LUBMAN, Stanley. Mao and Mediation: Politics and Dispute Resolution in Communist China. Califórnia Law Rewiew, n. 5, vol. 55. Califórnia: Berkeley Law Scholarship Repository, november, 1967, p. 1284 - 1359. Disponível em: <

http://scholarship.law.berkeley.edu/cgi/viewcontent.cgi?article $=2837 \&$ context $=$ californialawr eview>. Acesso 25 jul. 2014.

MANNHEIM, Karl. Educação como técnica social. In: PEREIRA, Luiz. FORACCHI, Marialice M. Educação e Sociedade. 8 ed. São Paulo: Ed. Nacional, 1977, p. 88 - 90

STEWART. W.A.C. O subgrupo de ensino. In: PEREIRA, Luiz.

FORACCHI, Marialice M. Educação e Sociedade. 8 ed. São Paulo: Ed. Nacional, 1977, p. 129 - 137. 
MAQUIAVEL, Nicolau. Comentários sobre a primeira década de Tito Lívio. $3^{\mathrm{a}}$ ed. Brasília: Editora Universidade de Brasília, 1994.

MARCUS, Michel. Security and democracy under pressure from violence. France: Council of Europe, 2003.

MARTINS FILHO, Ives Gandra da Silva. Evolução histórica da estrutura judiciária brasileira. Revista Jurídica Virtual. Brasília: Presidência da República. Casa Civil. Subchefia para Assuntos Jurídicos, v. 1, n. 5, set. 1999. Disponível em: < http://www.planalto.gov.br/ccivil_03/revista/Rev_05/evol_historica.htm>. Acesso 14 jun. 2014.

MCGILLIS, D. Community Mediation Programs: Developments and Challenges, Washington D.C.: Diane Publishing, 1997.

MINAYO, M. C. de S. A violência social sob a perspectiva da saúde pública. Cadernos de saúde pública, n. 10, pp. 7-18, suplemento 1, 1994.

MOORE, Christopher W. O processo de mediação: estratégias práticas para a resolução de conflitos. 2 ed. Porto Alegre: Artmed, 1998.

MOREIRA, Antônio Flavio Barbosa. SILVA, Tomás Tadeu da (org). Curriculo, cultura e sociedade. 7 ed. São Paulo: Cortez, 2002.

MORGAN, D. L. Focus groups as qualitative research. 2 ed. Thousand Oaks, London and New Dekhi: Sage Publications, 1997.

MOSÉ, Viviane (org). A escola e os desafios contemporâneos. Rio de Janeiro: Civilização Brasileira, 2013.

MUSZKAT, Malvina Ester. Guia prático de mediação de conflitos: em família e organizações. São Paulo: Summus, 2005.

NADEAU, Randal. Confucianism and the Problem of Human Rights. Intercultural Communication Studies, vol. 2, n. 11, Kingston: University of Rhode Island: International Association for Intercultrual Communication Studies, 2002, p. 107 - 118. Disponível em: <http://www.uri.edu/iaics/content/2002v11n2/07\%20Randall\%20Nadeau.pdf >. Acesso em 15 jul. 2014.

NASCIMENTO, Níveo Caixeta do (coord). Gestão e Governança da Segurança Pública no Distrito Federal e Entorno. Brasília: Escritório das Nações Unidas sobre Drogas e Crime UNODC Brasil e Cone Sul e Instituto Latino-Americano das Nações Unidas para Prevenção do Delito e Tratamento do Delinquente - Ilanud, 2011. Disponível em: < https://www.unodc.org/documents/lpo-brazil/noticias/2011/09setembro/Diagnostico_Gestao_e_Governanca.pdf>. Acesso em 10 jun. 2013.

NJAINE, Kathie; MINAYO, Maria Cecília de Souza. Violência na escola: identificando pistas para a Prevenção. Interface - Comunic, Saúde, Educ, Botucatu [on line], v.7, n.13, p. 119-34, 2003. Disponível em: < http://www.scielo.br/pdf/icse/v7n13/v7n13a08.pdf>. Acesso em 25 de mar. 2013. 
OLIVEIRA, Ana e GALEGO, Ana Marques. A mediação sócio-cultural: um puzzle em construção. Lisboa: Observatório de Imigração, mai. 2005. Disponível em: < http://www.oi.acidi.gov.pt/docs/Estudos\%20OI/Estudo\%2014.pdf>. Acesso 10 set. 2014.

ONU, Convenção sobre os direitos da Criança. Adotada em Assembléia Geral das Nações Unidas em 20 de junho de 1989. Unicef Brasil. Disponível em:

<http://www.unicef.org/brazil/pt/resources_10120.htm>. Acesso em 4 jun. 2014.

Declaração de Sevilha sobre a Violência. ONU. UNESCO, 1989.

Disponível em: <http://www.comitepaz.org.br/sevilha.htm>. Acesso 06 set. 2013.

Peacekiping Operations. 2014 Disponível em: <

http://www.un.org/en/peacekeeping/>. Acesso em 14 de junho de 2014.

ORTEGA, Rosario e DEL REY, Rosario. Estratégias educativas para a prevenção da violência. Brasília/DF: UNESCO, Universidade Católica de Brasília e Observatório de Violências nas Escolas, 2002.

OTTAWAY, A.K.C Education and society: an introducction to the sociology of education. 2 Ed. London: Routledge \& Kegan Paul, 1962.

PAIN, Jacques. Os desafios da escola em face da violência e da globalização: submeter-se ou resitir? In: SILVA, Joyce Mary Adam de Paula e. SALLES, Leila Maria Ferreira (org.).

Jovens, violência e escola: um desafio contemporâneo. São Paulo: Cultura Acadêmica, 2010, p. 7-26.

PAIVA, Wilson Alves de. Emílio: texto e contexto. Revista portuguesa de pedagogia, Coimbra: Faculdade de Psicologia e Ciências da Educação, ano 45, n. 02, 2011, p. 5-26. Disponível em: < http://iduc.uc.pt/index.php/rppedagogia/article/view/1339>. Acesso em 15 mai. 2014.

PARANÁ. Enfrentamento à violência na escola. Secretaria de Estado da Educação.

Superintendência da Educação. Diretoria de Políticas e Programas Educacionais.

Coordenação de Desafios Educacionais Contemporâneos- Curitiba: SEED - PR., 2010.

PASQUINO, Gianfranco. Conflito. In: BOBBIO, Norberto et all. Dicionário de Política. 8a. Edição. Brasília, DF: Editora Universidade de Brasília, 1995, p. 225 - 230.

PÉRES, Jesús Eduardo Canelón. O juiz de água: uma forma tradicional de organização de trabalhadores agrícolas para a distribuição de água de irrigação. Cadernos de Psicologia Social do Trabalho, vol. 9, n. 1, 2006, p. 73-90. Disponível em:

<http://www.revistas.usp.br/cpst/article/viewFile/25884/27616>. Acesso em 7 jun. 2013.

PETERS, Richard. Authority, Responsability and Education. London: George Allen \& Unwin Ltd. New York: Paul S. Erickson Inc., 1973.

PETR, Christopher G. Adultcentrism in Practice With Children. Families in Society: The Journal of Contemporary Human Services. Milwake: USA. Families International, Inc., 1992., p. 408 - 415. Disponível em: 
$<$ https://kuscholarworks.ku.edu/dspace/bitstream/1808/10361/1/Adultcentrism\%20in\%20Prac tice\%20With\%20Children.pdf>. Acesso em 3 jul. 2014.

PLATÃO. A república. São Paulo: Nova Cultural, 1999.

PONTES, Reinaldo Nobre. Mediação e Serviço Social. 2. ed. São Paulo: Cortez, 1997.

PRUTZMAN, Priscila et al.. Friendly handbook for a small planet: a handbok on creative aproaches to living and problem solving for children. New Jersey: Avery Publishing Group, 1978.

PUREZA, José Manuel. O desafio crítico dos estudados para a paz. Relações Internacionais. Dezembro, 2011, n. 32, p. 005-022. Disponível em: <

http://www.scielo.oces.mctes.pt/scielo.php?script=sci_arttext\&pid=S1645-

91992011000400001>. Acesso em $12 \mathrm{dez} 2012$.

QEDu: Aprendizado em Foco. Plataforma de informações educacionais. Disponível em: <http://www.qedu.org.br/sobre >. Acesso em 10 jun. 2013.

RANCIÈRE, Jacques. A partilha do sensível: estética e política. São Paulo: EXO Experimental e Editora 34, 2005.

O desentendimento: política e filosofia. São Paulo: Editora 34, 1996.

REARDON, Betty A. Direitos Humanos como Educação para a Paz. In: ANDREPOULOS, George J.; CLAUDE, Richard P. Educação em direitos humanos para o século XXI. São Paulo: Editora Universidade de São Paulo, Núcleo de Estudos da Violência, 2007, p. 61 - 80.

RIBEIRO, José Querino. Formas do Processo Educacional. In: PEREIRA, Luiz. FORACCHI, Marialice M. Educação e Sociedade. 8 ed. São Paulo: Ed. Nacional, 1977, p. 70 - 79.

RIQUELME, F. S. La Mediación social: itinerario histórico de la resolución de conflictos sociales. Contribuciones a las Ciencias Sociales, 2010. Disponível em:

<www.eumed.net/rev/cccss/07/sfr.htm>. Acesso 25 abr. 2012.

RISKIN, Leonard. Compreendendo as orientações, estratégias e técnicas do mediador: um padrão para perplexos. In: AZEVEDO, André Gomma (org). Estudos em arbitragem, mediação e negociação. Brasília: Brasília Jurídica, 2002.

ROBERS, S. et al. Indicators of School Crime and Safety: 2011 National Center for Education Statistics, U.S. Department of Education, and Bureau of Justice Statistics, Office of Justice Programs, U.S. Department of Justice. Washington, DC, 2012. Disponível em: <http://nces.ed.gov>. Acesso em 6 set. 2013.

ROUSSEAU, Jean-Jacques. Emílio ou da Educação. 3 ed. Rio de Janeiro: Bertrand Brasil, 1995.

RUEDIGER, M. A. RICCIO, V. Grupo focal: método e análise simbólica da organização e da sociedade. In: VIEIRA, M. M. F. ZOUAIN, D. M. (org). Pesquisa qualitativa em

administração. Rio de Janeiro: FGV, 2004, p. 151 - 172. 
RUSSEL, Bertrand. Educação e ordem social. São Paulo: Companhia Editora Nacional. 1956a.

Ensaios impopulares. São Paulo: Companhia Editora Nacional. 1956b.

RUSSEL, L. B. et al.. O uso do grupo focal em pesquisa qualitativa. Revista Texto Contexto Enfermagem, v. 17, n. 4. Florianópolis, outubro-dezembro 2008, p. 778 - 786. Disponível em: 〈http://www.scielo.br/pdf/tce/v17n4/21.pdf>. Acesso em 1 set. 2013.

SACAVINO, Suzana Beatriz. Democracia e educação em direitos humanos na América Latina. Petrópolis, RJ: DP et al.: De Petrus: Rio de Janeiro: Novamérica, 2009.

SALES, Lilia Maia de M. Justiça e mediação de conflitos. Belo Horizonte: Del Rey, 2003.

Mediação de conflitos: família, escola e comunidade. Florianópolis:

Editora Conceito, 2007.

SANCHES, Isabel. Compreender, Agir, Mudar, Incluir. Da investigação-acção è educação inclusiva. Revista. Lusófona de Educação [online]. 2005, n.5, pp. 127-142. Disponível em: $<$ http://www.scielo.oces.mctes.pt/scielo.php?pid=S1645-

$72502005000100007 \&$ script=sci_arttext $>$. Acesso em 15 jul. 2014.

SANG-JIN, Han. Confucianism and human rights. In: CHANG, Wonkuk e KALMANSON, Leah. Confucianism in Context Classic Philosophy and Contemporary Issues, East Asia and Beyond. New York: Suny Press, 2010, p. $121-147$.

SANTOS, Boaventura de Sousa. A Gramática do tempo: para uma nova cultura política. São Paulo: Cortez, 2006.

O discurso e o poder: ensaio sobre a sociologia da retórica jurídica. Porto Alegre: Sérgio Antonio Fabris Editor, 1988.

SAVIANI, Demerval. Instituição escolares: conceito, história, historiografia e práticas. Cadernos de História da Educação. Universidade Federal de Uberlâdia, n. 4, jan-dez de 2005, p. 27 - 33. Disponível em: < http://www.seer.ufu.br/index.php/che/article/viewFile/382/363>. Acesso em 15 mai. 2014.

SCARLATO, Elaine Cristina. SILVA, Marida. A violência cometida por professores/as em escolas brasileiras: uma face do lado sombrio da cartografia escolar brasileira. In: XI

Congresso Luso-Afro Brasileiro de Ciências Sociais: Diversidades e Desigualdades. Salvador, 7 a 10 de agosto de 2011. Universidade Federal da Bahia (UFBA), Campus de Ondina.

SEGATO, Rita. Antropologia e Direitos Humanos: Alteridade e Ética no movimento de expansão dos direitos universais. Mana. Estudos de Antropologia Social, vol. 12/1, abril de 2006. p. 207- 236.

SEVERNINI, E.R. A relação entre violência nas escolas e proficiência dos alunos. Rio de Janeiro, 2007, 49p. [Dissertação de Mestrado]- Departamento de Economia, Pontifícia Universidade Católica do Rio de Janeiro. Disponível em: 
$<$ http://www.esaf.fazenda.gov.br/premios/premios-1/premios-realizados/pasta-premio-ipeacaixa/monografias-

premiadas/?searchterm=impacto\%20da\%20viol\%C3\%AAncia\%20escolar $>$. Acesso em 24 out. 2013.

SHIPMAN, Marten Dorrington. The sociology of the school. 2a . Ed. Great Britain: Longman, 1975.

SILVA, Joyce Mary Adam de Paula e. Imaginário, cultura global e violência escola. In: SILVA, Joyce Mary Adam de Paula e. SALLES, Leila Maria Ferreira (org.). Jovens, violência e escola: um desafio contemporâneo. São Paulo: Cultura Acadêmica, 2010, p. 27 44.

SILVA, Maria José Lopes da. Um Aspecto da Função Ideológica da Escola: o Currículo Oculto. Boletim Técnico do Senac. v. 22, n. 2, mai-ago. 1996. Disponível em: < http://www.senac.br/BTS/222/boltec222e.htm>. Acesso em 25 jun. 2014.

SIM, May. A confucian approach to human rights. History of Philosophy Quartely, vol. 21, n. 4, Chicago: University of Illinois Press, October, 2004, p. 337 - 356. Disponível em: <http://www.jstor.org.stable/27745000>. Acesso 15 jul. 2014.

SINGER, Helena. República de crianças: sobre experiências escolares de resistência, Campinas: Mercado das Letras, 2010.

SIX, J. F. Dinâmica da mediação. Belo Horizonte: Del Rey, 2001.

Los Mediadores. Santander: SalTerrae, 2005.

SLYCK M, STERN M. Conflict resolution in educational settings. In: DUFFY, G. GROSCH, J. OLCZAK. R. (eds). Community mediation: A handbook for practitioners and researchers. New York: The Guilford Press. p.257-274, 1991.

SOREL. Nancy C. Peace and Social Concerns: The last forty years, 1955 - 1955. In: BARBOUR, Hugh et al..Quacker Crosscurrents - three hundred years of friends in th New York. New York: New York Early Meeting of the Religious Society of Friends, 1995, p. $276-320$.

SOUSA, José Cavalcante de. Heráclito de Éfeso. In: SOUSA, José Cavalcante de. Os présocráticos - fragmentos, doxografia e comentários. São Paulo: Nova Cultural, 1999.

SOUZA, Rosane Mantilla de. Mediação social: uma experiência de trabalho em comunidade de baixa renda. In: MUSZKAT, Malvina (org). Mediação de conflitos: pacificando e prevenindo a violência. São Paulo: Summus Editorial, 2003, p. 89-118.

SPOSITO, Maria. Um breve balanço da pesquisa sobre violência escolar no Brasil. Revista Educação e Pesquisa, vol. 27, no. 01, p. 87-103. Jun. 2001. Disponível em: <http://www.scielo.br/scielo.php?pid=S1517-97022001000100007\&script=sci_arttext $>$. Acesso em 24 de out. de 2013. 
STOPPINO, Mario. Poder. In: BOBBIO, Norberto et all. Dicionário de Política. 8 Ed. Brasília, DF: Editora Universidade de Brasília, 1995, p. 933-943.

TEIXEIRA, Anísio. A educação e a crise brasileira. São Paulo: Companhia Editora Nacional, 1956.

TEIXEIRA, E.C. KASSOUF, A.L. A relação entre violência nas escolas e desempenho acadêmico no estado de São Paulo em 2007: uma análise multinível. Anais do I Circuito de Debate Acadêmico. IPEA, CODE 2011.

TOCQUEVILLE, Aléxis. A democracia na América - sentimentos e opiniões - de uma profusão de sentimentos e opiniões que o estado social democrático faz nascer entre os americanos. São Paulo: Martins Fontes, 2004.

TOLSTÓI, Leon. A escola de Iasnaia Poliana: novembro e dezembro de 1862. In: Educação libertária. Disponível em: <https://we.riseup.net/educacaolibertaria/tolst\%C3\%B3i-lievescola-de-iasnaia-poliana+240314>. Acesso em 25 jun 2013.

TORRES, Haroldo da Gama et al. O que pensam os jovens de baixa renda sobre a escola. São Paulo: CEBRAP, Fundação Victor Civita, Estudos e Pesquisas Educacionais, junho de 2013. Disponível em: <http://www.fvc.org.br/estudos-epesquisas/2012/pdf/relatorio_jovens_pensam_escola.pdf>. Acesso em 24 out. de 2013.

TRIBUNAL DE LAS AGUAS DE LA VEGA DE VALÊNCIA. Disponível em: < http://www.tribunaldelasaguas.org/es/>. Acesso 15 jul. 2014.

UNB, Universidade de Brasília, Lista de projetos aprovados pelo DEX 2013 a 2016. Brasília: Decanato de Extensão. Diretoria |Técnica de Extensão, 2013. Disponível em: <http://www.unb.br/administracao/diretorias/dte/arquivos/Documentos\%202014/ppeac_28_m aio.pdf> Acesso em 06 de junho de 2014.

VASQUEZ, Jorge Daniel. Adultocentrismo y juventud: aproximaciones foucaulteanas. In: Revista Sophia, n. 15, 2013. Cuenca: Universidade Salesiana Politécnica de Ecuador, p. 217 -234. Disponível em:

<http://sophia.ups.edu.ec/documents/2515411/4585304/SOPHIA+15_art8.pdf >. Acesso 5 jul. 2014.

VELHO, Maria T. A. de Campos. QUINTANA, Alberto M. ROSSI, Alvaro G. Rossi. Adolescência, autonomia e pesquisa em seres humanos. Revista Bioética. n. 22, 2014, p. 76 84. Disponível em:

<http://revistabioetica.cfm.org.br/index.php/revista_bioetica/article/view/884/976>. Acesso em 06 jun. 2014.

VELOSO, Marília Lomanto. AMORIM, Simone. LEONELLI, Vera (org). Mediação popular: uma alternativa para a construção da justiça. Salvador: Juspopuli Escritório de Direitos Humanos, 2009.

INSTITUTO DE TECNOLOGIA SOCIAL Direitos humanos e mediação de conflitos. São Paulo : Instituto de Tecnologia Social . Secretaria Especial de Direitos Humanos-SEDH, 2009. Disponível em: 
<http://www.dhnet.org.br/dados/cursos/mediar_conflitos/curso_m_conflitos_modulos_1_10.p df>. Acesso em 15 jul. 2014.

VICARIO, Beatriz Palacios. GARCIA, Andrea Gutierrez. GÓMES, María Cruz Sanches. NVIVO una herramienta de utilidad en el mundo de la comunicación. In: $\mathbf{2}^{\mathbf{0}}$ Congreso

Nacional sobre Metodología de la Investigación en Comunicación: Investigar la Comunicación hoy. Revisión de políticas científicas y aportaciones metodológicas. Valladolid: Facultad de Ciencias Sociales, Jurídicas y de la Comunicación, 2013, p. 10031018. Disponível em: <https://uvadoc.uva.es/handle/10324/3070>. Acesso em 13 abr. 2013.

WAISELFISZ, Julio Jacobo. Mapa da Violência: Os Jovens do Brasil. Brasília: SecretariaGeral da Presidência da República. Secretaria Nacional da Juventude, 2014. Disponível em: http://www.mapadaviolencia.org.br/pdf2014/Mapa2014_JovensBrasil.pdf .

WARAT, Luis Alberto. Ecologia, psicanálise e mediação. In: WARAT, Luis Alberto (org). Em nome do acordo: a mediação no direito. 2 ed. Buenos Aires: aLMed, 2001, p. 5-59.

Boiteux, 2004. Surfando na pororoca: ofício do mediador. Florianópolis: Fundação

WEBER, Max. Economia e sociedade: fundamentos da sociologia compreensiva. Brasília: Editora Universidade de Brasília. São Paulo: Imprensa Oficial do Estado de São Paulo, 2004, vol. 2. Disponível em: <http://ayanrafael.files.wordpress.com/2011/08/weber-m-economia-esociedade-fundamentos-da-sociologia-compreensiva-volume-2.pdf $>$. Acesso em 27 mai. 2014.

WENDEL, Catherine Wihtol de. Uma história dos subúrbios. Sociologia, Problemas e práticas, n. ${ }^{\circ}$ 56, 2008, p. 37-59. Disponível em:

<http://www.scielo.oces.mctes.pt/pdf/spp/n56/n56a03>. Acesso em 23 jun. 2013.

WESTPHAL, M. F. BOGUS, C. M. FARIA, M. de M. Grupos focais: experiências precursoras em programas educativos em saúde no Brasil. Boletín de La Oficina Sanitaria Panamericana. n. 6, vol. 120, 1996 p. 472 - 482. Disponível em:

<http://hist.library.paho.org/spanish/bol/v120n6p472.pdf>. Acesso em 1 set. 2013.

WIEVIORKA, Michel. O novo paradigma da violência. Tempo social; Revista de Sociologia da US. São Paulo: USP, n. 9(1), p. 5+41, maio de 1997.

YIN, R. K. Estudo de caso: planejamento e método. 2 ed. Porto Alegre: Bookman, 2001.

ZALUAR, Alba. Integração preserva: pobreza e tráfico de drogas. Rio de Janeiro: editora FGV, 2004. 


\section{APENDICE A - ROTEIRO PARA GRUPO FOCAL}

FASE 1: OBJETIVOS: identificar a percepção dos atores sobre a escola; analisar os conflitos e violências da escola; identificar as formas de tratamento que a escola dá a esses conflitos e violências; verificar o currículo invisível da escola.

PERGUNTAS:

1. Fale da escola de seus sonhos.

2. Como você gostaria que sua escola fosse?

3. Como é a escola de vocês?

a. Pontos positivos; pontos negativos

b. O que gosta e o que não gosta na escola?

c. Quais são os acontecimentos mais comuns na escola?

d. Como são?

4. O que é conflito / violência?

5. Por que acontecem esses conflitos e violência?

6. Como a escola lida com esses conflitos? Há algumas ações? Há algum programa?

7. Como esses conflitos/violências podem ser prevenidos, minimizados?

FASE 2: OBJETIVOS: verificar percepção dos atores sobre o programa "Estudar em Paz", em especial quanto a expectativas, impactos, dificuldades, pontos positivos e negativos; verificar como se dá a implantação do programa na escola, o que pode ser feito para melhorar.

1. Qual a percepção de vocês sobre o programa "Estudar em paz"?

2. Que expectativas possuíam sobre o programa?

3. Como o programa se desenvolveu?

4. Que ações foram realizadas?

5. Houve mediações individuais? Coletivas? Eventos? Participação da Rede Social?

6. Quem atuou?

7. Como foi a atuação?

8. Quais as dificuldades encontradas nessas ações?

9. Que impactos o programa promoveu?

10. O que precisa melhorar?

11. Qual sua opinião sobre o programa?

12. Se você pudesse o que você manteria ou mudaria no programa? 


\section{APÊNDICE B - ROTEIRO DE ENTREVISTA}

1. Apresentação da entrevista e obtenção de termo de consentimento

2. Objetivos: rapport e realizar um apanhado geral do que será a entrevista

a. Questões para atores escolares: fale-me sobre a sua escola e a sua experiência na escola.

b. Questões para atores do programa: fale-me sobre sua atuação no programa.

3. Objetivos: identificar a percepção dos atores sobre a escola; analisar os conflitos e violências da escola; verificar o currículo invisível

a. Questões: Quais os conflitos que você mais vivenciou na escola?

b. Há/houve casos de violência? Como foi?

4. Objetivos: identificar as formas de tratamento que a escola dá a esses conflitos e violências.

a. Que ações a escola desenvolve para lidar com os conflitos e violências?

5. Objetivos: verificar percepção dos atores sobre o programa "Estudar em Paz", em especial quanto a expectativas, impactos, dificuldades, pontos positivos e negativos; verificar como se dá a implantação do programa na escola, o que pode ser feito para melhorar.

a. Como se deu o desenvolvimento do programa?

b. Que ações foram realizadas? Houve mediações individuais? Coletivas?

Eventos? Participação da rede? Quem atuou? Como foi?

c. Quais as expectativas da escola quanto ao programa?

d. Quais as dificuldades do programa?

e. Quais os impactos do programa: para os alunos participantes?

f. O que precisa melhorar?

6. Objetivos: finalizar e observar se tudo foi falado: há algo mais que gostaria de compartilhar / falar? 


\section{APENDICE C - TERMO DE CONSENTIMENTO PARA PARTICIPAÇÃO EM PESQUISA}

$\mathrm{Eu}$,

(profissão)

$(\mathrm{CPF})$

da

regional

(telefone)

declaro ter sido informado(a) sobre a pesquisa

"Estudar em paz: um estudo de caso sobre mediação de conflitos no contexto escolar", que analisa a implementação de programa de mediação de conflitos em escolas da rede pública do Distrito Federal, tendo ciência de que minhas declarações serão utilizadas exclusivamente para fins acadêmicos, sendo garantido o sigilo absoluto de fonte (sem a identificação de nome, local de trabalho, de estudo ou ainda minha filiação). Tenho ainda ciência de que tenho o direito a ter esclarecimentos permanentes sobre a pesquisa junto ao pesquisador responsável, de interromper minha participação e retirar meu consentimento a qualquer momento, de ter acesso aos dados referentes a minha participação e de receber o resultado final da pesquisa.

Diante disso, CONCORDO com a minha participação e ( ) CONCORDO ( ) NÃO CONCORDO COM A GRAVAÇÃO DA ENTREVISTA.

Assinatura: 


\section{ANEXO A - RELATÓRIO FINAL de COORDENADOR 2011}

1. IDENTIFICAÇÃO DO PROJETO E COORDENADOR

\begin{tabular}{|c|c|}
\hline $\begin{array}{l}\text { TÍTULO DO PROJETO / PROGRAMA } \\
\text { DE EXTENSÃO - PEAC }\end{array}$ & $\begin{array}{l}\text { ESTUDAR EM PAZ - MEDIAÇÃO DE CONFLITOS NO CONTEXTO } \\
\text { ESCOLAR }\end{array}$ \\
\hline UNIDADE DE ORIGEM DO PEAC & CEAM \\
\hline ÁREA TEMÁTICA PRINCIPAL & DIREITOS HUMANOS E JUSTIÇA \\
\hline COORDENADOR (A) & NAIR HELOISA BICALHO DE SOUSA \\
\hline VÍNCULO & $\begin{array}{l}\text { ( ) TÉCNICO ( X ) DOCENTE ( ) ESTUDANTE DE PÓS (STRICTU } \\
\text { SENSO) }\end{array}$ \\
\hline TELEFONE & (61) 3307-2219 (NEP) /(61) 3349-6826 (CEAM) \\
\hline EMAIL & NAIR.BICALHO@GMAIL.COM \\
\hline $\begin{array}{l}\text { RA(s) OU RIDE(s) DE ATUAÇÃO DO } \\
\text { PEAC NO DF OU OUTRO ESTADO }\end{array}$ & SÃO SEBASTIÃO, PARANOÁ, RECANTO DAS EMAS E GAMA. \\
\hline $\begin{array}{l}\text { LOCAL DE DESENVOLVIMENTO DO } \\
\text { PEAC NA(s) COMUNIDADE(s) }\end{array}$ & $\begin{array}{l}3 \text { ESCOLAS DA REDE PÚBLICA DO DF E A REGIONAL DE ENSINO } \\
\text { DO GAMA. }\end{array}$ \\
\hline $\begin{array}{l}\text { O PEAC É VINCULADO A } \\
\text { PROGRAMA DE EXTENSÃO }\end{array}$ & $\begin{array}{l}\text { ( ) NÃO } \\
\text { (X ) SIM, INDIQUE QUAL: PIBEX }\end{array}$ \\
\hline $\begin{array}{l}\text { ENDEREÇO DO PEAC NA INTERNET } \\
\text { (TWITTER, BLOG, ORKUT, SITE, } \\
\text { ETC.) }\end{array}$ & $\begin{array}{l}\text { BLOG: estudarempaz.blogspot.com } \\
\text { FACEBOOK: /estudarempaz }\end{array}$ \\
\hline
\end{tabular}

2. MEMÓRIA DO PEAC

\begin{tabular}{|l|l|}
\hline ANO DE CRIAÇÃO & 2010 \\
\hline No DE REEDIÇÕES DO PEAC & 01 \\
\hline O PROJETO TEVE OUTROS COORDENADORES? NÃO - SE SIM, CITAR NOME E O ANO. \\
\hline NOME: & ANO: \\
\hline MOTIVADORES PARA A CRIAÇÃO DO PEAC & $\begin{array}{l}\text { O PEAC está teoricamente fundamentado na dissertação de } \\
\text { mestrado intitulada "A mediação social como instrumento de } \\
\text { participação para a realização da cidadania”, de Flávia Tavares } \\
\text { Beleza/Política Social/UnB, desenvolvida sob a orientação da } \\
\text { professora doutora Nair Heloisa Bicalho de Sousa. Diante da } \\
\text { exacerbação dos conflitos nas escolas e do potencial transformador } \\
\text { e pacificador da mediação social, o projeto foi acolhido pelo } \\
\text { Núcleo de Estudos para a Paz e os Direitos Humanos (NEP) para } \\
\text { ser desenvolvido nas escolas da rede pública do Distrito Federal. } \\
\text { Como a repercussão do projeto tem sido muito positiva, cada vez } \\
\text { mais diretores e orientadores educacionais procuram a coordenação } \\
\text { do projeto para solicitar a implementação do mesmo em novas } \\
\text { escolas. Este tem sido um estímulo para o planejamento de ações } \\
\text { futuras. }\end{array}$ \\
\hline
\end{tabular}

3. EQUIPE DE EXECUÇÃO

\begin{tabular}{|l|l|l|}
\hline NÚMERO DE PARTICIPANTES DA UNB NA ORGANIZAÇÃO E EXECUÇÃO (ATUAL) \\
\hline DOCENTES & $\mathrm{N}^{\circ} 01$ & FAC/DEP/INST: SERVIÇO SOCIAL \\
\hline ESTUDANTES - BOLSISTAS & $\mathrm{N}^{\circ} 12$ & $\begin{array}{l}\text { CURSOS: SERVIÇO SOCIAL, PSICOLOGIA, } \\
\text { LETRAS/TRADUÇO }\end{array}$ \\
\hline ESTUDANTES - NÃO BOLSISTAS & $\mathrm{N}^{\circ} 01$ & CURSOS: SOCIOLOGIA \\
\hline
\end{tabular}

\footnotetext{
${ }^{9}$ Desse total, três alunos são bolsistas do DEX.
} 


\begin{tabular}{|l|l|l|}
\hline ESTUDANTES DE PÓS - GRADUAÇÃO & $\mathrm{N}^{\circ}$ & CURSOS: \\
\hline TÉCNICOS ADMINISTRATIVOS & $\mathrm{N}^{\circ}$ & UNIDADES ADMINISTRATIVAS: \\
\hline
\end{tabular}

\begin{tabular}{|l|l|l|}
\hline \multicolumn{2}{|l|}{ NÚMERO DE PARTICIPANTES EXTERNOS A UNB NA ORGANIZAÇÃO E EXECUÇÃO (ATUAL) } \\
\hline DOCENTES & $\mathrm{N}^{\circ} 02$ & $\begin{array}{l}\text { UNIVERSIDADE(S): UNIVERSIDADE CATÓLICA DE } \\
\text { BRASÍLIA }^{10}\end{array}$ \\
\hline ESTUDANTES & $\mathrm{N}^{\circ} 2$ & $\begin{array}{l}\text { UNIVERSIDADE(S): UNIVERSIDADE CATÓLICA DE } \\
\text { BRASIILIA }\end{array}$ \\
\hline TÉCNICOS & $\mathrm{N}^{\circ}$ & INSTITUIÇÃO(S): \\
\hline $\begin{array}{l}\text { COLABORADORES VOLUNTÁRIOS } \\
\text { DA COMUNIDADE }\end{array}$ & $\mathrm{N}^{\circ} 01$ & $\begin{array}{l}\text { REGIÃO: BRASÍLIA } \\
\text { PESQUISADORA COLABORADORA DO NEP - Voluntária }\end{array}$ \\
\hline
\end{tabular}

\begin{tabular}{|l|l|}
\hline NOME DA INSTITUIÇÃO & \multicolumn{1}{|l|}{ PARCERIAS COM INSTITUIÇAO GOVERNAMENTAL } \\
\hline RIDE/RA & \\
\hline PERÍODO & \\
\hline OBJETO DA PARCERIA & $\begin{array}{l}\text { ( ) CONVÊNIO } \\
\text { ( ) ACORDO } \\
\text { ( ) TERMO DE COOPERAÇÃO } \\
\text { ( ) OUTRO. INDIQUE }\end{array}$ \\
\hline
\end{tabular}

\begin{tabular}{|l|l|}
\multicolumn{1}{c|}{5.} & PARCERIAS COM INSTITUIÇAO NÃO GOVERNAMENTAL \\
\hline NOME DA INSTITUIÇÃO & INSTITUTO PRÓ-MEDIAÇÃO \\
\hline RIDE/RA & BRASÍLIA \\
\hline PERÍODO & $2009-2011$ \\
\hline OBJETO DA PARCERIA & COLABORAÇÃO TÉCNICA SEM EXIGÊNCIA DE CONTRAPARTIDA \\
\hline REALIZADO POR: & $\begin{array}{l}\text { ( ) CONVÊNIO } \\
\text { ( ) ACORDO } \\
\text { (X) TERMO DE COOPERAÇÃO } \\
\text { ( ) OUTRO. INDIQUE }\end{array}$ \\
\hline
\end{tabular}

6. AÇÕES E PARCERIAS DO PEAC COM OUTROS PROJETOS INSTITUCIONAIS

\begin{tabular}{|l|}
\hline O PEAC TEM PARCERIA COM \\
PROJETOS OU PROGRAMAS \\
INSTITUCIONAIS DA UNB \\
\hline O PEAC TEM PARCERIA COM \\
PROJETOS OU PROGRAMAS \\
INSTITUCIONAIS EXTERNOS A \\
UNB \\
\hline
\end{tabular}

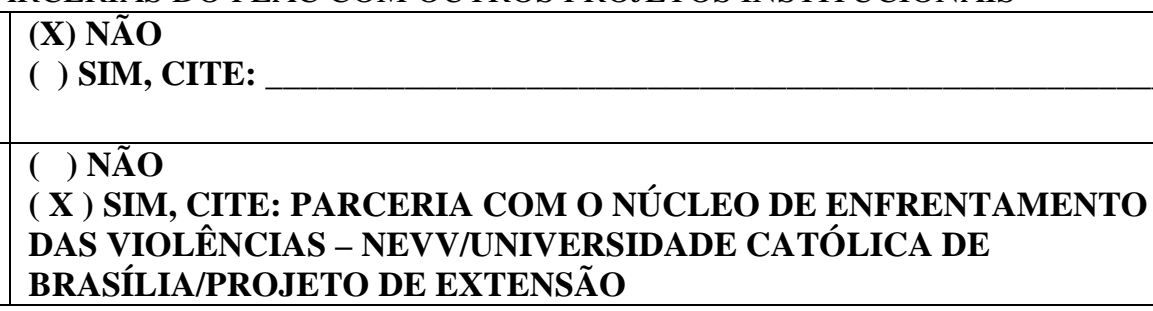

7. PERFIL DA COMUNIDADE COM O QUAL O PROJETO / PROGRAMA TRABALHA

\begin{tabular}{|c|c|}
\hline NUMERO ESTIMADO DE PÚBLICO ENVOLVIDO & 5.700 (total de professores, alunos e servidores das três escolas). \\
\hline FAIXA ETÁRIA & (X) 0 A 12 (X) 13 A 20 (X) 21 A 60 ( ) ACIMA DE 60 \\
\hline \multicolumn{2}{|c|}{$\begin{array}{l}\text { COLETIVOS ORGANIZADOS } \\
\text { ( ) ASSOCIAÇÕES, CITE: } \\
\text { ( ) COOPERATIVAS, ITE: } \\
\text { ( ) MOVIMENTOS SOCIAIS, CITE: } \\
\text { (X) ONGS. (1) CITE: MOVIMENTO CULTURAL SUPERNOVA/ SÃO SEBASTIÃO } \\
\text { (X) ESCOLA, CITE: CENTRO EDUCACIONAL SÃO FRANCISCO (SÃO SEBASTIÃO), CEF } 02 \text { (PARANOÁ), CEF } 602 \\
\text { (RECANTO DAS EMAS) E REGIONAL DE ENSINO DO GAMA. }\end{array}$} \\
\hline
\end{tabular}

${ }^{10} \mathrm{O}$ projeto foi aprovado pela UCB/NEVV (Núcleo de Enfrentamento das Violências), em 2011 e deverá ser implementado em 2012. 


\section{PRODUTOS GERADOS}

PRODUÇÃO ACADÊMICA: (TIPO: ARTIGO, CARTILHA, MANUAIS, MONOGRAFIA, DISSERTAÇÃO, TESE). FAZER CITAÇÃO BIBLIOGRÁFICA ABNT (AUTOR, TITULO, ANO, CIDADE, EDITORA ETC.) numere as citações e indique entre parêntese o tipo de produção.

$\square$ (j) CARTILHA - (BELEZA, Flávia. Mediação social no contexto escolar. Brasília, 2011) A cartilha foi elaborada para subsidiar o processo de capacitação dos mediadores discentes, docentes e servidores públicos e privados. Público: todas as comunidades escolares. Texto: Flávia Beleza. Ilustração: Roberta Senda, aluna de graduação da Sociologia, UnB/DF (voluntária).

登(d) MONOGRAFIA - (OVÍDIO, Daniela. Estudar em Paz: uma experiência de mediação de conflitos no contexto escolar. Brasília: Universidade de Brasília, 2011).

馵(d) TRABALHO DE CONCLUSÃO DE PÓS-GRADUAÇÃO - (RIBEIRO, Éverton Ibargoyen. Alternativas para uma economia da vida. Brasília: Universidade Católica de Brasília, 2011). Aluno vinculado ao Programa de Pós-Graduação em Planejamento e Gestão Ambiental da Universidade Católica de Brasília, que tomou contato com o projeto com a visita proposta pelo Professor Edson Kondo (UCB), que levou todos os seus alunos de pós-graduação para conhecerem o Projeto Estudar em Paz no CED São Francisco, em São Sebastião, em maio de 2011.

PRODUÇÃO CULTURAL: (TIPO: SITE, DVD, BLOG, TWITTER, APRESENTAÇÕES ARTÍSTICAS, OUTROS). FAZER CITAÇÃO (AUTORES, TITULO, CIDADE, ANO, URL ETC.) numere as citações e indique entre parêntese o tipo de produção.

1) BLOG DO PROJETO ESTUDAR EM PAZ - http://estudarempaz.blogspot.com . Blog criado para divulgação das ações do projeto, em julho de 2009. O blog também é utilizado para compartilhar textos, vídeos, fotos, notícias e divulgar os eventos realizados pelo projeto. Administrado pela coordenação do projeto. Até a presente data, foram registradas 765 visualizações.

2) BLOG DOS MEDIADORES DO RECANTO DAS EMAS/DF: http://estudarempazcef602.blogspot.com. Blog criado pelos mediadores do CEF 602 do Recanto das Emas/DF, em agosto de 2011. O blog também é utilizado para compartilhar textos, vídeos, fotos do projeto. Administrado pelo Prof. Francisco Celso Leitão, coordenador do projeto no CEF 602 do Recanto das Emas e pelos mediadores da escola.

3) FACEBOOK - /estudarempaz. Criado e administrado pela coordenação do projeto para divulgar as ações e blogs do projeto. $\mathrm{O}$ facebook permite uma troca de informação mais ágil.

4) APRESENTAÇÕES ARTÍSTICAS (O projeto desenvolve uma ação de sensibilização - Mediação, Paz e Amor - , na qual uma banda com três músicos e os alunos mediadores da escola cantam, dançam e convidam a comunidade escolar para conhecer e participar das demais ações do projeto. Em 2011 o projeto realizou 3 festas: uma no CEF 02 (Paranoá/DF), em 30 de maio de 2011, uma no CED São Francisco (São Sebastião/DF), em 03 de junho de 2011, e a terceira no CEF 602 no Recanto das Emas/DF, em 16 de setembro de 2011.

5) PROGRAMAS DE TELEVISÃO -

5.1) Programa Alternativo - SBT/Brasília, destaca projetos do CED São Francisco, onde o Projeto Estudar em Paz é o "carro chefe". O programa foi ao ar em 22 de janeiro de 2011.

Fonte: http://www.youtube.com/watch?v=3kUhZC21JYY

5.2) Programa Alternativo - SBT/Brasília. A formatura da $1^{a}$ turma de mediadores de conflito do CEF 602 foi destaque do Programa Alternativo, que foi ao ar no dia 15 de outubro de 2011 (dia dos professores).

Fonte: http://www.youtube.com/watch?v=b_ymNKISp-U\&feature=player_embedded

\section{6) MATÉRIAS JORNALÍSTICAS}

6.1) Titulo: "Escolas. Em busca de segurança". Jornal de Brasília, 18 de abril de 2011. Matéria realizada logo após o massacre na escola municipal Tasso da Silveira, em Realengo, na Zona Oeste do Rio de Janeiro. A cidade de São Sebastião/DF é citada na reportagem por apresentar altos índices de violência escolar. O Projeto Estudar em Paz aparece como uma iniciativa exemplar do CED São Francisco (São Sebastião/DF), por apresentar resultados positivos: "A confiança entre equipe e alunos aumentou, não há mais pichações dentro da escola, as brigas diminuíram, inclusive na área externa da escola" (depoimento de Leísa Sasso, Diretora do CED São Francisco, São Sebastião/DF). http://www.pmdf.df.gov.br/?pag=noticia\&txtCodigo=8235

6.2) Título: "Escola em São Sebastião oferece mais de 40 atividades interdisciplinares". Correio Braziliense, 13 de maio de 2011. Matéria sobre as atividades interdisciplinares oferecidas pelo CED São Francisco, com destaque para o Projeto Estudar em Paz. Fonte: http://www.correiobraziliense.com.br/app/noticia/cidades/2011/05/13/interna_cidadesdf,252003/escola-em$\underline{\text { sao-sebastiao-oferece-mais-de-40-atividades-interdisciplinares.shtml. }}$

7) VÍDEOS DO PROJETO PUBLICADOS NO YOUTUBE. Após a formação em mediação, cada turma produz seu vídeo para publicar no Youtube. Os conflitos abordados nas simulações de mediação são escolhidos, roteirizados e ensaiados pelos mediadores, conforme a realidade de cada escola, sob a orientação da coordenação do projeto.

7.1- VÍDEO 1 - "ESTUDAR EM PAZ" - REALIZADO PELOS ALUNOS DA PRIMEIRA TURMA DE MEDIADORES DO CED SÃO FRANCISCO, SÃO SEBASTIÃO/DF, PUBLICADO EM 2009. 
DIANTE DA INEXISTÊNCIA DE VÍDEOS DE MEDIAÇÃO ESCOLAR EM PORTUGUÊS, OS ALUNOS MEDIADORES DECIDIRAM REALIZAR O PRIMEIRO VÍDEO DE MEDIAÇÃO EM LÍNGUA PORTUGUESA A SER PUBLICADO NO YOUTUBE, PARA FACILITAR A FORMAÇÃO DOS FUTUROS MEDIADORES DO PROJETO. APÓS ESSA INICIATIVA DOS ALUNOS, TODAS AS TURMAS SEGUINTES QUISERAM REALIZAR SEUS VÍDEOS PARA PUBLICAR NO YOUTUBE.

7.2 - VÍDEO $3^{11}$ - "Inclusão - Alunos com necessidades especiais". Vídeo de formatura da $3^{\text {a }}$ turma de mediadores do CED São Francisco, São Sebastião/DF. Os mediadores tratam do tema da inclusão de alunos com necessidades especiais na rede pública de ensino, cujas dificuldades (conflitos) são bem conhecidas por um dos mediadores que produziram o vídeo, que é cadeirante e tem dificuldades de fala. Realizado em novembro e dezembro de 2011 e publicado em fevereiro de 2012. Duração: $7 \min 35 \mathrm{seg}$.

7.3 - VIDEO 4 - “Aceitação das diferenças: as diversas tribos e a convivência no espaço escolar". Vídeo de formatura da primeira turma de mediadores do CEF 602, Recanto das Emas/DF. Os mediadores escolheram o tema da convivência na escola, onde diferentes grupos de alunos convivem diariamente. Diante da intolerância observada, os mediadores decidiram mostrar a mediação na escola como um espaço de fala, escuta, reflexão e acolhimento das diferenças. Realizado em novembro e dezembro de 2011, publicado em fevereiro de 2012. Duração: $9 \mathrm{~min} 03 \mathrm{seg}$.

7.4 - VIDEO 5 - "Conhecendo a mediação". Vídeo de formatura da primeira turma de mediadores do CEF 02, Paranoá/DF. A mediadora Juliana de Sousa Ramos Oliveira aborda importantes aspectos teóricos e práticos da mediação e termina com um depoimento pessoal, mostrando que a mediação é um instrumento de transformação individual e coletiva. Realizado em novembro e dezembro de 2011, publicado em fevereiro de 2012. Duração: $8 \min 47 \mathrm{seg}$.

7.5 - VIDEO 6 - "A arte da mediação". Vídeo de confraternização realizado pelos alunos mediadores do CED São Francisco (São Sebastião/DF), alunos mediadores do CEF 602 ( Recanto das Emas/DF) e funcionários mediadores do CED São Francisco (São Sebastião/DF). Os funcionários mediadores, servidores da limpeza e da portaria, são terceirizados, mas participam dos cursos de mediação. Realizado em novembro e dezembro de 2011, publicado em fevereiro de 2012. Duração: 3minutos.

PROPOSIÇÃO DE CURSOS, MINICURSOS, OFICINAS, WORKSHOPS, DISCIPLINAS ETC. RELACIONADAS AO PROJETO. FAZER CITAÇÃO (TITULO, LOCAL DE REALIZAÇÃO, DATA, PROPONENTES ETC.) numere as citações e indique entre parêntese o tipo de produção.

CURSOS REALIZADOS PELA EQUIPE COORDENADORA E PELOS MEDIADORES FORMADOS PELO PROJETO:

- Curso de formação de mediadores para professores, CEF 02, Paranoá/DF, com 36 horas, de 21.02.2011 a 09.05.2011. (26 participantes).

- Curso de formação de mediadores para alunos, Centro Educacional São Francisco, São Sebastião/DF, com 36 horas, de 12.03.2011 a 21.05.2011. (30 participantes).

- Curso de formação de mediadores para diretores e orientadores, Regional de Ensino do Gama/DF, com 36 horas, de 17.03.2011 a 30.06.2011. (28 participantes).

- Curso de formação de mediadores para servidores (pessoal da limpeza e da portaria), Centro Educacional São Francisco, São Sebastião/DF, com 24 horas, de 24.05.2011 a 12.08.201. (12 participantes).

- Curso de formação de mediadores para alunos, CEF 02, Paranoá/DF, com 36 horas, de 06.06.2011 a 29.09.2011. (12 participantes).

- Curso de formação de mediadores para alunos, CEF 602, Recanto das Emas/DF, com 36 horas, de 09.05.2011 a 22.06.201. (17 participantes).

- Participação na abertura dos cursos de formação de mediadores para orientadores da rede pública de ensino, na Escola de Aperfeiçoamento de Profissionais da Educação - EAPE, Brasília/DF. Dias 18 e 23 de agosto de 2011. Apresentar a mediação de conflitos no contexto escolar e a experiência do Projeto Estudar em Paz. (30 participantes).

- Oficina realizada no encerramento do Curso de Mediação para 30 orientadores educacionais, com a participação de 09 alunos mediadores do CED São Francisco/DF, CEF 02 do Paranoá/DF e CEF 602 do Recanto das Emas/DF, em 22.11.2011. Local: Escola de Aperfeiçoamento de Profissionais da Educação - EAPE, Brasília/DF.

PARTICIPAÇÃO EM CONGRESSOS, SEMINÁRIOS, FÓRUNS, ENCONTROS, MESA REDONDA ETC. FAZER CITAÇÃO (TITULO, CIDAdE, DATA, CARÁTER DA PARTICIPAÇÃO - OUVINTE OU COMUNICADOR, ETC.) numere as citações e indique entre parêntese o tipo de produção.

Z(j) OLINDA CIDADE EDUCADORA, CONSTRUINDO UMA CULTURA DE PAZ. Evento promovido pela Secretaria de Educação de Olinda para a abertura da Formação dos Educadores da Rede Municipal de Ensino de Olinda/PE, nos dias $1^{\circ}, 2$ e 3 de fevereiro de 2011.

CIDADE: OLINDA/PE

11 O VÍDEO 2, da segunda turma de mediadores do CED São Francisco (São Sebastião/DF), está em fase de produção. Os mediadores escolheram um importante tema: conflito entre professores e alunos. Será publicado em breve. 
DATA: 01/02/2011 - Manhã e tarde.

PALESTRA DE ABERTURA - Cultura de Paz/Mediação de Conflitos.

PALESTRANTE: Flávia Beleza.

LOCAL: Faculdade Integrada Barros Melo - AESO / Av. Transamazônica, 405 - Jardim Brasil II - Olinda e Faculdade de Comunicação, Tecnologia e Turismo de Olinda - FACOTTUR / Av. Getúlio Vargas, 1360 - Bairro Novo/ Olinda.

国 (d) PROGRAMA DE MEDIAÇÃO ESCOLAR DO TRIBUNAL DE JUSTIÇA DE GOIÁS. Evento realizado pela Comissão Permanente de Conciliação, juntamente com coordenadores e diretores de escolas municipais de Goiânia.

CIDADE: Goiânia/GO.

DATA: $27 / 04 / 2011$

MESA: Projeto de Extensão da UnB - "Estudar em Paz: mediação de conflitos no contexto escolar".

PALESTRANTES: Ghisa Porto - Vice-diretora do CED São Francisco; Daniela Ovídio - aluna do último período de Serviço Social / UnB - extensionista do projeto; Stephany Cristina da Silva, ex-aluna e mediadora do CED São Francisco - formada na primeira turma/2009; Thais Ketlyn da Silva - aluna mediadora do CED São Francisco/8 ${ }^{a}$ série, formada na última turma e Flávia Beleza.

LOCAL: Auditório do Ministério Público do Estado de Goiás, Goiânia.

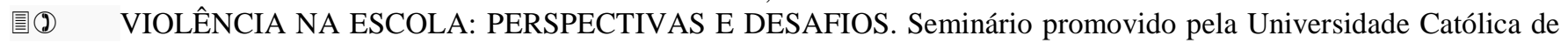
Brasília - UCB Virtual.

CIDADE: Taguatinga/DF.

DATA: 23/07/2011

PALESTRA: Mediação de conflitos no contexto escolar: a experiência do Projeto Estudar em Paz.

PALESTRANTE: Flávia Beleza

LOCAL: Auditório 2, Universidade Católica de Brasília, Taguatinga/DF.

MEDIÇÃO DE CONFLITOS NO CONTEXTO ESCOLAR. Palestra de encerramento do curso "Orientação Educacional e Projeto Interventivo", promovido pela Escola de Aperfeiçoamento dos Profissionais da Educação - EAPE, Brasília/DF.

CIDADE: Brasília/DF.

DATA: 23/08/2011.

PALESTRANTE: Flávia Beleza

LOCAL: Escola de Aperfeiçoamento dos Profissionais da Educação - EAPE, Brasília/DF.

ESTUDAR EM PAZ: MEDIAÇÃO DE CONFLITOS NO CONTEXTO ESCOLAR. Palestra realizada na coordenação coletiva dos Orientadores Educacionais da Regional de Ensino de Samambaia/DF.

CIDADE: Samambaia/DF.

DATA: $23 / 09 / 2011$

PALESTRANTE: Flávia Beleza, com participação do professor Francisco Celso (coordenador do projeto no CEF 602, Recanto das Emas/DF).

LOCAL: CEF 01, Samambaia/DF.

VIOLÊNCIA NAS ESCOLAS. Encontro com supervisores pedagógicos, coordenadores, orientadores educacionais e professores das Instituições Públicas de Ensino da Diretoria Regional de Ensino do Plano Piloto e Cruzeiro - DRE / PPC / Núcleo de Monitoramento Pedagógico - NPM para refletir sobre aspectos das violências que ocorrem dentro dos espaços escolares e construir caminhos para a cultura de paz.

CIDADE: Brasília/DF.

DATA: 27/09/2011 - Horário: 8 h30 às 11 h30

PALESTRA: Mediação de conflitos no contexto escola.

PALESTRANTE: Flávia Beleza.

LOCAL: Auditório do Centro de Ensino Especial 01 de Brasília, SGAS 912 - Asa Sul.

CONVERSANDO SOBRE CIDADANIA. Programa do Tribunal de Justiça do Distrito Federal e Território. TEMA: FAMÍLIA NA ATUALIDADE - COMPARTILHANDO VISÕES E VIVÊNCIAS NA COMUNIDADE. Seminário promovido pelo Programa Justiça Comunitária - TJDFT .

CIDADE: Taguatinga/DF.

DATA: 22/10/2011 - Horário: 10h40

MESA: Interfaces da Família - educação, saúde e comunidade.

PALESTRANTE: Flávia Beleza (Tema: A mediação na interface escola/família)

LOCAL: Centro de Formação e Pesquisa em Justiça Comunitária , localizado na QNC 23 - Área Especial - Fórum de Taguatinga, Taguatinga/DF.

ORIENTAÇÃO EM AÇÃO: CONSTRUINDO IDENTIDADE NO SERVIÇO DE ORIENTAÇÃO EDUCACIONAL. Evento de encerramento do ano letivo de 2011, organizado pela Diretoria Regional de Ensino do Gama/DF.

CIDADE: Gama/DF.

DATA: 23/11/2011. Horário: $15 \mathrm{~h} 30$ às $16 \mathrm{~h} 30$

PALESTRANTE: Flávia Beleza, com participação da professora Michelle Confessor (EAPE/DF) - Tema: “O orientador como mediador".

LOCAL: Centro de Ensino Médio 01, Gama/DF. 


\section{O PROJETO APRESENTOU ATIVIDADE (EXECENTUA-SE A EXPOSIÇÃO DE PÔSTER PIBEX) NA SEMANA UNIVERSITÁRIA 2011? SE SIM, INDIQUE O TITULO DA ATIVIDADE, MODALIDADE E PUBLICO DE}

INTERESSE

SIM. Mesa redonda sobre o projeto "Estudar em Paz", em 06 de outubro de 2011, no Auditório do CEAM/UnB, para estudantes da UnB, professores, pessoas da comunidade e demais interessados.

9. PREMIAÇÕES RECEBIDAS PELO PROJETO / PROGRAMA DESDE A SUA CRIAÇÃO

\begin{tabular}{|l|l|}
\hline $\begin{array}{l}\text { 10. RECURSOS FINANCEIROS } \\
\text { OINANCACIRA }\end{array}$ & ( )SIM (X) NÃO \\
\hline SE SIM, IDENTIFIQUE A ORIGEM DOS RECURSOS & $\begin{array}{l}\text { ( ) RECURSOS PRÓPRIOS } \\
\text { ( ) RECURSOS EXTERNOS }\end{array}$ \\
\hline VALOR & $\begin{array}{l}\text { ( )CONVÊNIO } \\
\text { ( )CONTRATO } \\
\text { ( ) ) EDITAIS INTERNO } \\
\text { ( ) EDITAIS EXTERNO } \\
\text { ( ) ) OUTRO INSTRUMENTO. INDIQUE: }\end{array}$ \\
\hline COMO FORAM APLICADOS OS RECURSOS & $\begin{array}{l}\text { ( )RECURSOS HUMANOS } \\
\text { ( )COMPRA DE EQUIPAMENTO } \\
\text { ( )MATERIAL DE CONSUMO } \\
\text { ( ) ALUGUEL DE IMÓVEIS } \\
\text { ( )BOLSAS } \\
\text { ( ) PRÓ LABORES } \\
\text { ( ) PASSAGENS / DIARIAS / HOSPEDAGEM } \\
\text { ( ) OUTRO. INDIQUE: }\end{array}$ \\
\hline
\end{tabular}

\section{AVALIAÇÃO GERAL}

\section{OBJETIVOS PROPOSTOS}

OBJETIVO GERAL: Capacitar estudantes, professores, corpo técnico-administrativo e pais de alunos em mediação social no contexto escolar, visando a consolidar uma compreensão da mediação como instrumento para uma prática cidadã junto as escolas de rede pública de ensino do Distrito Federal.

O projeto "Estudar em Paz: Mediação de Conflitos no Contexto Escolar" é um Projeto de Extensão de Ação Contínua - PEAC da Universidade de Brasília/UnB, sob a coordenação do Núcleo de Estudos para a Paz e os Direitos Humanos - NEP. O projeto tem como objetivo levar a proposta da mediação social para as escolas da rede pública de ensino do Distrito Federal, por meio da formação de mediadores/as sociais (alunos/as, professores/as, servidores/as, corpo técnico-administrativo e pais/mães e pessoas da comunidade) e da promoção dos valores da Cultura de Paz, dos direitos humanos, de justiça social e cidadania.

\section{OBJETIVOS ESPECÍFICOS:}

1 - Possibilitar a leitura de textos sobre mediação social, de modo a construir uma compreensão embasada em experiências bem sucedidas de transformação de conflitos no contexto escolar;

2 - Fomentar junto aos capacitandos práticas educativas pautadas na Cultura de Paz, direitos humanos, justiça e cidadania;

3 - Incentivar junto aos diferentes segmentos sociais a incorporação da prática da mediação como instrumento de diálogo e participação no contexto escolar;

4 - Supervisionar e acompanhar os alunos formados em mediação escolar na primeira etapa, nas atividades teóricas e práticas a serem desenvolvidas junto aos novos participantes inscritos no projeto.

5 - Difundir a experiência da mediação no contexto escolar do CED São Francisco junto à rede de ensino do Distrito Federal*. *Nos objetivos foram incluídas mais duas escolas e uma regional de ensino: o CEF 02 (Paranoá/DF), o CEF 602 (Recanto das Emas/DF) e a Regional de Ensino do Gama/DF.

\section{OBJETIVOS ALCANÇADOS}

Todos os objetivos do projeto foram alcançados. O momento é de aprimoramento da metodologia e amadurecimento do projeto, para continuar a sua difusão na rede pública de ensino do Distrito Federal. 


PRINCIPAIS DIFICULDADES
rede social local. Uma das ações do projeto é tecer a rede entre a escola, a família e a comunidade e promover os direitos de
cidadania. Nesse sentido, os alunos bolsistas estão fazendo um mapeamento da rede social de proteção das três cidades do
projeto (São Sebastião, Paranoá e Recanto das Emas) para melhorar o apoio às escolas. A maior dificuldade tem sido obter as
informações necessárias das instituições públicas (Conselho Tutelar, Centro de Referência de Assistência Social-CRAS,
Centro de Atenção Psicossocial- CAPS e outras), diante da precariedade dos registros, de recursos e de pessoal.
a A (D) A pequena quantidade de alunos bolsistas dificulta o trabalho, visto que o projeto está em 3 escolas de comunidades
diferentes, além da parceria com a Diretoria da Regional de Ensino do Gama.
la A falta de recursos financeiros também dificulta a expansão do PEAC. As despesas com camisetas, festas,
certificados, material pedagógico, deslocamentos e alimentação são custeadas pelos coordenadores do projeto.

QUAL É A FORMA DE ACOMPANHAMENTO DO PEAC E OS INSTRUMENTOS APLICADOS PARA
AFERIÇÃO DE RESULTADOS JUNTO A COMUNIDADE
O PEAC realiza aferição de resultados por meio de pesquisa qualitativa e com grupos focais. Foram realizadas duas pesquisas:
uma pela coordenação do PEAC e alunos bolsistas com alunos mediadores do CED São Francisco, a outra foi realizada por
um colaborador externo, junto aos professores do CED São Francisco. Os resultados foram bastante positivos: a grande
maioria dos alunos e professores considerou positiva a mediação na escola. As pesquisas estão publicadas nos seguintes
trabalhos:
MONOGRAFIA (TCC) - (OVÍDIO, Daniela. Estudar em Paz: uma experiência de mediação de conflitos no contexto escolar.
Brasília: Universidade de Brasília, 2011).
TRABALHO DE CONCLUSÃO DE PÓS-GRADUAÇÃO - (RIBEIRO, Éverton Ibargoyen. Alternativas para uma economia
da vida. Brasília: Universidade Católica de Brasília, 2011. Aluno vinculado ao Programa de Pós-Graduação em Planejamento
e Gestão Ambiental, da Universidade Católica de Brasília/DF.

\section{O PEAC PRETENDE CONTINUAR DESENVOLVEND O SUAS ATIVIDADES NA COMUNIDADE ATUAL? TEM PESPECTIVAS DE EXPANSÃ DE SUA ATUAÇÃO OU CONTINUIDADE DAS ATIVIDADES EM OUTRAS COMUNIDADES?}

Dentre os objetivos do PEAC consta a intenção de difusão do projeto. O PEAC tem interesse em continuar nas três escolas das comunidades já citadas e no Gama (Regional de Ensino), além de se expandir para outras escolas em outras comunidades interessadas. A demanda pelo projeto é crescente, mas a capacidade de atendimento ainda é limitada, tendo em vista as dificuldades já relatadas (PRINCIPAIS DIFICULDADES). O objetivo é levar o Projeto Estudar em Paz para toda a rede pública de ensino do Distrito Federal.

\section{HOUVE INTERESSE DA COMUNIDADE NA PERMANENCIA DA ATUAÇÃO DO PEAC NA REGIÃO?}

SIM. AS três escolas e a Regional de Ensino do Gama têm interesse na continuidade do PEAC. Para 2012, o Centro de Ensino Fundamental 01 do Paranoá-DF, o Centro de Ensino Médio 01 (Centrão) de Taguatinga/DF e a Regional de Ensino de Samambaia pediram prioridade no cronograma do projeto. Outras escolas ainda terão que aguardar.

\section{O PEAC PRETENDE CONTINUAR DESENVOLVENDO SUAS ATIVIDADES SOBRE A MESMA LINHA TEMATICA OU TEM PESPECTIVA DE MUDANÇA?}

O PEAC pretende continuar na mesma linha temática (DIREITOS HUMANOS E JUSTIÇA), principalmente pelo momento atual de descoberta da mediação de conflitos como instrumento de realização dos direitos humanos e da cidadania, nas escolas públicas do Distrito Federal.

\section{QUAIS SÃO AS PERSPECTIVAS DE POTENCIALIZAÇÃO DO TRABALHO DO PEAC COM OUTRAS} INICIATIVAS ACADEMICAS?CITE AS POSSIVEIS NOVAS PARCERIAS.

1) Recentemente, o PEAC realizou uma parceria com o Núcleo de Enfrentamento das Violências (NEVV), da Universidade Católica de Brasília. O objetivo é congregar conhecimento e força de trabalho para a multiplicação do PEAC. Em 2012, alunos de extensão da UnB e da Católica trabalharão juntos, trocarão experiências e saberes. Como outras áreas de conhecimento se juntam nesse PEAC, a mediação alcança status transdisciplinar.

2) Uma parceria com a Escola de Aperfeiçoamento dos Profissionais de Educação (EAPE) está em processo de concretização, uma vez que os coordenadores e os mediadores do projeto já participaram de palestras e cursos na instituição. Para 2012, o objetivo é criar um curso de mediação permanente para orientadores educacionais e professores da rede pública de ensino, seguindo os parâmetros teóricos e metodológicos do PEAC.

3) Um GT de Mediação no Contexto Escolar está em desenvolvimento, em parceria com a Universidade Católica e com a EAPE, com o objetivo de promover o diálogo entre mediadores formados pelo PEAC e profissionais de diversas áreas para aperfeiçoamento das ações do projeto. O GT acontecerá no Núcleo de Estudos para a Paz e os Direitos Humanos (NEP), quinzenalmente.

4) Cabe lembrar que a expansão do projeto para as regiões administrativas do Paranoá/DF, Recanto das Emas/DF e Gama/DF só foi possível devido a oferta de novas bolsas de graduação por parte do DGP/MEC. 
12. RELAÇÃO UNIVERSIDADE/COMUNIDADE ENVOLVIDA NA CONSTRUÇÃO E

DESENVOLVIMENTO DO PROJETO/PROGRAMA

\begin{tabular}{|l|}
\hline O PROJETO / PROGRAMA DE EXTENSÃO \\
PROPICIOU A PARTICIPAÇÃO DA \\
COMUNIDADE NA: \\
\hline $\begin{array}{l}\text { O PROJETO PROPICIOU AUMENTO DE } \\
\text { RENDA PARA A COMUNIDADE? JUSTIFIQUE }\end{array}$
\end{tabular}

CONCEPÇÃO DO PROJETO/PROGRAMA

( )SIM (X) NÃO

DESENVOLVIMENTO DO PROJETO PROGRAMA

( X)SIM ( ) NÃO

AVALIAÇÃO DO PROJETO/PROGRAMA

(X) SIM ( ) NÃO

RENDA PARA A COMUNIDADE? JUSTIFIQUE

SIM. O Projeto não tem como objetivo direto o aumento de renda.

No entanto, aumenta a possibilidade de que isso aconteça, pois os mediadores formados pelo projeto aprendem a buscar e a se fazer oportunidade. Melhoram a autoestima, a forma de falar, organizam melhor suas demandas, tornam-se mais solidários e participativos na comunidade. Alunos mediadores já relataram ter conseguido melhores vagas em empregos por conta da mediação, por terem melhorado as suas habilidades de fala, desenvoltura e convivência. Alguns venceram mais facilmente a etapa da "entrevista de emprego", ou seja, a etapa da seleção.

HOUVE APROPRIAÇÃO DE RECURSOS TECNOLÓGICOS PELA COMUNIDADE (FERRAMENTAS, MAQUINÁRIO, INSTRUMENTOS ETC.) OU ADOÇÃO DE NOVAS TECNOLOGIAS?

SIM. A mediação de conflitos é uma espécie de tecnologia social capaz de transformar pessoas, situações e realidades sociais. Os mediadores formados pelo projeto (em toda a comunidade escolar) desenvolvem habilidades para lidar com os conflitos de forma pacífica e positiva, melhoram a comunicação, a postura, a capacidade de avaliar situações, interpretar, pensar criticamente, traçar metas e planejar o futuro. Logo que aprendem a prática social da mediação, em aulas e práticas supervisionadas na escola, os mediadores passam a prestar mais atenção nos conflitos do colega, do vizinho, do familiar e se predispõem a colaborar. Tornam-se mais solidários e participativos na escola, na família e na comunidade. Esses recursos apropriados valem para toda a vida.

O PROJETO PROPICIOU INTEGRAÇÃO DE GRUPOS NA COMUNIDADE? SE SIM, DE QUE FORMA?

SIM, principalmente de alunos mediadores, que adquirem uma identidade própria. Os que primeiro buscam a formação em mediação são aqueles que chamamos de "sem voz", os excluídos. Porque são pobres, ou tímidos, ou gordos, ou homossexuais... Eles são atraídos pelo projeto justamente porque sofrem o peso do conflito interno e externo. Querem ser parte, pertencer a um grupo, ser respeitados. Participar do grupo da mediação significa interagir com todos, pois os mediadores são participativos, observadores, pacíficos, preocupados com a coletividade e solidários. Os mediadores são exatamente aqueles que vão promover a criação de laços entre os diversos grupos na escola, em casa e na comunidade. Diante dos conflitos, os mediadores fazem o exercício de observação do contexto, o que os leva a buscar recursos para lidar com eles além dos muros da escola. Daí a importância de conhecer a sua cidade e os serviços públicos disponíveis em sua comunidade, além de saber acessá-los. $O$ projeto colabora realizando um mapeamento da rede social das cidades que acolhem o projeto.

HOUVE APROPRIAÇÃO DE CONCEITOS E PRÁTICAS PELA COMUNIDADE A PARTIR DA ABORDAGEM DO PEAC?
SIM. Os participantes do projeto conheceram a mediação como uma prática social capaz de criar e recriar laços sociais, que tem 3 funções fundamentais: função dialógica, função participativa e função pacificadora. Aprenderam que conflito e violência não são a mesma coisa e que a paz (paz positiva) é uma construção de uma vida inteira. Logo de início, se apropriaram da ideia de que os conflitos são oportunidades de crescimento e transformação e que os conflitos movem as transformações sociais. Aprendem a lidar com os conflitos (realidade conflituosa) de forma dialógica, pacífica, cooperativa, criativa e positiva. Também aprendem muito sobre Cultura de Paz, direitos humanos, cidadania e reconhecem mais facilmente as violências, especialmente a estrutural e a cultural 
(que inclui a simbólica). Por isso são conhecidos como cidadãos entre os cidadãos. Exercer esse ofício requer que o mediador seja alguém que saiba estimular mudanças e gerar reflexões e ações, sempre com humildade. Assim, a mediação passa a ser uma ferramenta cotidiana para melhor lidar com os conflitos pessoais e sociais, seja na escola, na família e na comunidade.

DATA: $09 / 02 / 2012$

ASSINATURA E MATRÍCULA DO COORDENADOR

\title{
OBJETIVO GERAL
}

O projeto tem como objetivo levar a proposta da mediação social para as escolas da rede pública de ensino do Distrito Federal, por meio da formação de mediadores/as sociais (alunos/as, professores/as, servidores/as, corpo técnico-administrativo e pais/mães e pessoas da comunidade) e da promoção dos valores da Cultura de Paz, dos direitos humanos, de justiça social e cidadania.

\author{
PROGRAMA PARA OS ALUNOS \\ Programa
}

carga

Horária

Estudar em Paz: mediação social e Cultura de Paz

03 horas

O conflito: visão positiva; tipos de conflito; análise multifatorial

03 horas

Violências: tipos de violência; análise multifatorial

03 horas

Mediação social no contexto escolar: conceito; características; princípios; objetivos; o papel do

06 horas ediador.

Fases da mediação e comediação

- Práticas Simuladas

03 horas

- Práticas Supervisionadas

10 horas

12 horas

\section{JUSTIFICATIVA}

Em meio a profundas transformações econômicas, políticas, sociais e tecnológicas, as escolas enfrentam uma sequência de episódios violentos envolvendo todos os seus atores. São diversas as pesquisas (ABRAMOVAY e RUAS, 2002; FREIRE, SIMÃO e FERREIRA, 2006) que demostram que o cotidiano escolar é permeado por várias formas de violência, entre elas discriminação e preconceito racial, de gênero, geracional, étnico, de orientação sexual-afetiva, de classe e outras formas de intolerância social. A recente pesquisa de Abramovay (2009) demostrou que 53,4\% dos alunos e alunas afirmaram já ter visto discriminação na escola, sendo $23,4 \%$ afirmaram já ter sofrido e 52,8\% das professoras e professores afirmaram já ter visto discriminação na escola e $16 \%$ já ter sofrido. Os estudos citados destacam, ainda, um cotidiano marcado por gritos, agressões verbais, falta de respeito do professor em relação aos alunos e vice-versa.

A escola, como uma instituição democrática de fundamental importância na incorporação de novos paradigmas, é um instrumento necessário para enfrentar as situações de preconceitos, discriminações e expressões de violência direta, estrutural e cultural - incluindo a simbólica e a institucional -, que violam e negam os Direitos Humanos. Este espaço representa o primeiro passo para garantir oportunidades efetivas de todas as pessoas nos diferentes espaços sociais. A formação ética, política e social, por meio da metodologia da mediação social, mostra-se imprescindível nesse momento de transformação, pois rompe com isolamento das disciplinas que se propõem unicamente a responder às necessidades do conhecimento acadêmico, apartado dos elementos históricos que os fundam.

Na intenção de colaborar para a construção de uma nova educação, uma educação mais holística, o projeto Estudar em Paz: Mediação de Conflitos no Contexto Escolar foi concebido com o objetivo de levar a proposta da mediação social para as escolas da rede pública de ensino do Distrito Federal, com a formação de mediadores sociais nas escolas (alunos, professores, servidores, pais/responsáveis e comunidade) para a promoção dos Direitos Humanos, da Cultura de Paz, da justiça social, da cidadania, da democracia e do respeito à diversidade. Seguindo uma concepção dialética da educação, a mediação social no contexto escolar propõe-se a mostrar as desigualdades e as contradições, ou seja, a realidade conflituosa. Nunca esconder, negar ou camuflar os conflitos cotidianos, mas mostrar como e por que a interação das partes é conflituosa e que o conflito é uma oportunidade de crescimento e transformação individual e coletiva. 


\section{REFERENCIAL TEÓRICO (RESUMO)}

O projeto está teoricamente fundamentado na mediação social de origem francesa ${ }^{12}$, surgida na década de 1980 (FRANÇA, 2002, p. 9), trazida para a realidade brasileira com as adequações necessárias, levando-se em conta as diferenças socioeconômicas, políticas e culturais dos dois países. Optar pela mediação social significa adotar uma concepção de mediação voltada para a criação de laços sociais como forma de prevenir a exclusão ${ }^{13}$ de certas populações:

A mediação social é definida como um processo de criação e de recriação do laço social e de regulação dos conflitos da vida cotidiana, na qual um terceiro imparcial e independente tenta, por meio da organização de mudanças entre as pessoas ou instituições, auxiliá-las a melhorar uma relação ou a regulamentar um conflito que as opõe (FRANÇA, 2000, p. 74).

Esse alargamento conceitual possibilita pensar a mediação para além de um simples método de solução de conflitos $\left(\mathrm{ADR}^{14}\right)$, mas como um processo de múltiplas orientações: criação e recriação do laço social, regulação dos conflitos cotidianos, mudanças (ou trocas) entre pessoas ou instituições e melhoria das relações em geral.

Cabe destacar que a mediação social está especialmente voltada para a melhoria das relações entre os/as cidadãos/ãs, como também entre os/as cidadãos/ãs e as instituições que prestam serviços públicos, entre organizações comunitárias e entre essas e o Estado. Por isso a mediação social é guiada pelo princípio da participação cidadã e do envolvimento da comunidade e está conectada ao conceito de integração social e política do cidadão (FRANÇA, 2000, p. 14).

Partindo-se do pressuposto que a educação para e pela cidadania começa na escola (GADOTTI, 2008, p. 66), no contexto escolar, a mediação social se apresenta como uma ação socioeducativa importante, capaz de colaborar para a formação de cidadãos/ãs conscientes da sua realidade, uma vez que a reflexão produzida no processo de mediação do conflito contribui para pensar (desvelar) a realidade conflituosa, a discriminação, a opressão, a exclusão e as violências em todas as suas manifestações (BELEZA, 2009 ${ }^{15}$ ).

A mediação social no contexto escolar pode ser considerada um processo de educação para a paz na medida em que favorece o reconhecimento e a análise crítica do conflito, concebido como realidade conflituosa, visto que toda educação é um ato de aproximação da realidade para transformá-la, segundo Paulo Freire: "Por isso mesmo a conscientização é o olhar mais crítico possível da realidade, que a des-vela para conhecê-la e para conhecer os mitos que enganam e que ajudam a manter a realidade da estrutura dominante" (FREIRE, 2005, p. 33).

Levando-se em conta que o homem é um ser de relações e essas relações se dão com o outro e com o mundo (FREIRE, 2008, p.30), no contexto escolar o/a mediador/a é aquele/a que faz comunicar (SIX, 2001), que propõe o diálogo e estabelece ligações entre todos na escola, entre a escola e a comunidade e entre esta e a sociedade mais ampla. O objetivo da criação desses laços é a ampliação dos recursos para lidar com os conflitos que permeiam o contexto escolar, principalmente aproximando a escola da rede de proteção social (pública e privada).

Atualmente, mais que lidar com os conflitos na escola, os/as educadores/as querem "resolver" o problema da violência na escola. Para Debarbieux (2006, p. 23), existe um "alarde midiático" em torno de uma crescente "violência escolar" e uma exploração sensacionalista do fenômeno, que têm por detrás objetivos políticos e econômicos, como desvincular a violência escolar da violência social. O mais acertado seria buscar uma unidade conceitual, concebendo a violência unicamente como algo que se opõe à ética, de acordo com Marilena Chauí (1999, p. 3): "violência é um ato de brutalidade, sevícia e abuso físico e/ou psíquico contra alguém e caracteriza relações intersubjetivas e sociais definidas pela opressão e intimidação, pelo medo e o terror".

O/a mediador/a social trabalha para que a violência no contexto escolar seja conhecida em toda a sua complexidade - direta, estrutural, cultural $^{16}$ - (GALTUNG, 1990, p. 294), como fruto da desigualdade social,

\footnotetext{
12 Nos objetivos foram incluídas mais duas escolas e uma regional de ensino: o CEF 02 (Paranoá/DF), o CEF 602 (Recanto das Emas/DF), a Regional de Ensino do Gama/DF e de Samambaia/DF.

${ }^{13}$ Para Robert Castel, a exclusão não significa uma ausência de relação social e por isso não há ninguém fora da sociedade. As relações com o centro da sociedade é que são mais ou menos distendidas, e por vezes deixam os "excluídos por um fio", como ocorre com os desempregados e com as populações "mal escolarizadas, mal alojadas, mal cuidadas, mal consideradas etc." (CASTEL, 1998, p. 569). São esses "excluídos" que Castel prefere qualificar como desfiliados: "foram des-ligados, mas continuam dependendo do centro que, talvez, nunca foi tão onipresente para o conjunto da sociedade" (1998, p. 569).

${ }^{14}$ ADR-Alternative Dispute Resolution, é uma nomenclatura criada nos Estados Unidos, nos anos 1970, para os métodos alternativos de solução de conflitos, como a negociação, arbitragem, conciliação e mediação.

15 Trechos do trabalho Mediação Escolar: Por uma cultura de paz, de autoria de Flávia Beleza. Disponível em http://www.catedra.ucb.br.

${ }^{16}$ Galtung classifica a violência em três supertipos (1990, p. 294): 1) Violência Direta - existe uma relação clara e direta entre o sujeito e o objeto e sua ação pode ser verbal ou física; 2) Violência Estrutural - é indireta,
} 
cultural e econômica; do isolamento; da pobreza política ${ }^{17}$; do esgarçamento das redes de solidariedade; do autoritarismo que rege as relações humanas nas institucionais; da ineficiência e ineficácia das políticas sociais e da reprodução de uma cultura da violência que enaltece o individualismo, a competição, o consumismo e a intolerância na sociedade contemporânea.

Assim, a mediação social no contexto escolar colabora para a formação de sujeitos conscientes, questionadores, dialogantes, participativos, criativos, solidários e amorosos, porque não há diálogo nem confiança sem amor (FREIRE, 2005, p. 92).

transmitida pela estrutura (repressão), resultante da desigualdade de poder; 3) Violência Cultural - aspectos da esfera simbólica que servem para minimizar ou ocultar as anteriores.

${ }^{17}$ Segundo Pedro Demo, pobreza política significa a ignorância do pobre quanto a sua condição de pobreza, ou seja, quando este "sequer sabe e é coibido de saber que é pobre, não atinando para a injustiça de sua condição humana" (2003, p. 41). 


\title{
ANEXO B - RELATÓRIO FINAL de COORDENADOR 2012
}

\author{
PROJETO OU PROGRAMA DE EXTENSÃO \\ (DIGITAR E ENTREGAR ASSINADO, VIA UNBDOC, À DIRETÓRIA TÉCNICA DE EXTENSÃo / \\ DEX)
}

2. IDENTIFICAÇÃO DO PROJETO E COORDENADOR

\begin{tabular}{|l|l|}
\hline $\begin{array}{l}\text { TÍTULO DO PROJETO / PROGRAMA } \\
\text { DE EXTENSÃO - PEAC }\end{array}$ & $\begin{array}{l}\text { ESTUDAR EM PAZ - MEDIAÇÃO DE CONFLITOS NO CONTEXTO } \\
\text { ESCOLAR }\end{array}$ \\
\hline UNIDADE DE ORIGEM DO PEAC & CEAM \\
\hline ÁREA TEMÁTICA PRINCIPAL & DIREITOS HUMANOS E JUSTIÇA \\
\hline COORDENADOR (A) & NAIR HELOISA BICALHO DE SOUSA \\
\hline VÍNCULO & $\begin{array}{l}\text { ( ) TÉCNICO ( X ) DOCENTE ( ) ESTUDANTE DE PÓS (STRICTU } \\
\text { SENSO) }\end{array}$ \\
\hline TELEFONE & (61) 3307-2219 (NEP) /(61) 3349-6826 (CEAM) \\
\hline EMAIL & NAIR.BICALHO@ GMAIL.COM \\
\hline $\begin{array}{l}\text { RA(s) OU RIDE(S) DE ATUAÇÃO DO } \\
\text { PEAC NO DF OU OUTRO ESTADO }\end{array}$ & SÃO SEBASTIÃO, PARANOÁ, RECANTO DAS EMAS E GAMA. \\
\hline $\begin{array}{l}\text { LOCAL DE DESENVOLVIMENTO DO } \\
\text { PEAC NA(s) COMUNIDADE(s) }\end{array}$ & $\begin{array}{l}\text { 3 ESCOLAS DA REDE PÚBLICA DO DF E A REGIONAL DE ENSINO } \\
\text { DO GAMA. }\end{array}$ \\
\hline $\begin{array}{l}\text { O PEAC É VINCULADO A } \\
\text { PROGRAMA DE EXTENSÃO }\end{array}$ & $\begin{array}{l}\text { ( ) NÃO } \\
\text { (X) SIM, INDIQUE QUAL: PIBEX }\end{array}$ \\
\hline $\begin{array}{l}\text { ENDEREÇO DO PEAC NA INTERNET } \\
\text { (TWITTER, BLOG, ORKUT, SITE, } \\
\text { ETC.) }\end{array}$ & $\begin{array}{l}\text { BLOG: estudarempaz.blogspot.com } \\
\text { FACEBOOK: /estudarempaz }\end{array}$ \\
\hline
\end{tabular}

\begin{tabular}{|l|l|}
\hline \multicolumn{2}{|l|}{ 2. MEMÓRIA DO PEAC } \\
\hline ANO DE CRIAÇãO & 2010 \\
\hline No DE REEDIÇÕES DO PEAC & 02 \\
\hline O PROJETO TEVE OUTROS COORDENADORES? NÃO - SE SIM, CITAR NOME E O ANO. \\
\hline NOME: & ANO: \\
\hline MOTIVADORES PARA A CRIAÇÃO DO PEAC & $\begin{array}{l}\text { O PEAC está teoricamente fundamentado na dissertação de } \\
\text { mestrado intitulada "A mediação social como instrumento de } \\
\text { participação para a realização da cidadania", de Flávia Tavares } \\
\text { Beleza/Política Social/UnB, desenvolvida sob a orientação da } \\
\text { professora doutora Nair Heloisa Bicalho de Sousa. Diante da } \\
\text { exacerbação dos conflitos nas escolas e do potencial transformador } \\
\text { e pacificador da mediação social, o projeto foi acolhido pelo } \\
\text { Núcleo de Estudos para a Paz e os Direitos Humanos (NEP) para } \\
\text { ser desenvolvido nas escolas da rede pública do Distrito Federal. } \\
\text { Como a repercussão do projeto tem sido muito positiva, cada vez } \\
\text { mais diretores e orientadores educacionais procuram a coordenação } \\
\text { do projeto para solicitar a implementação do mesmo em novas } \\
\text { escolas. Este tem sido um estímulo para o planejamento de ações } \\
\text { futuras. }\end{array}$ \\
\hline
\end{tabular}

3. EQUIPE DE EXECUÇÃO

\begin{tabular}{|l|l|l|}
\hline \multicolumn{3}{|l|}{ NÚMERO DE PARTICIPANTES DA UNB NA ORGANIZAÇÃO E EXECUÇÃO (ATUAL) } \\
\hline DOCENTES & $\mathrm{N}^{\circ} 01$ & FAC/DEP/INST: SERVIÇO SOCIAL \\
\hline ESTUDANTES - BOLSISTAS & $\mathrm{N}^{\circ} 12$ & CURSOS: SERVIÇO SOCIAL, PSICOLOGIA, ARTES. \\
\hline ESTUDANTES - NÃO BOLSISTAS & $\mathrm{N}^{\circ}$ & CURSOS: SOCIOLOGIA \\
\hline $\begin{array}{l}\text { ESTUDANTES DE PÓS - } \\
\text { GRADUAÇÃO }\end{array}$ & $\mathrm{N}^{\circ} 01$ & $\begin{array}{l}\text { CURSOS: MESTRADO EM DIREITOD HUMANOS E } \\
\text { CIDADANIA }\end{array}$ \\
\hline
\end{tabular}




\begin{tabular}{|c|c|c|}
\hline \multicolumn{2}{|c|}{ TÉCNICOS ADMINISTRATIVOS } & UNIDADES ADMINISTRATIVAS: \\
\hline \multicolumn{3}{|c|}{ NÚMERO DE PARTICIPANTES EXTERNOS A UNB NA ORGANIZAÇÃO E EXECUÇÃO (ATUAL) } \\
\hline DOCENTES & $\mathrm{N}^{\mathrm{o}}$ & \\
\hline ESTUDANTES & $\mathrm{N}^{\mathrm{o}} 1$ & $\begin{array}{l}\text { UNIVERSIDADE(S): UNIVERSIDADE CATÓLICA DE BRASÍLIA - } \\
\text { PSICOLOGIA SOCIAL }\end{array}$ \\
\hline TÉCNICOS & $\mathrm{N}^{\mathrm{o}}$ & INSTITUIÇÃO(S): \\
\hline $\begin{array}{l}\text { COLABORADORES } \\
\text { VOLUNTÁRIOS } \\
\text { DA COMUNIDADE }\end{array}$ & $\mathrm{N}^{\mathrm{o}} 02$ & $\begin{array}{l}\text { REGIÃO: BRASÍLIA } \\
\text { 01 ADVOGADA PESQUISADORA COLABORADORA DO NEP } \\
\text { 01 ASSISTENTE SOCIAL }\end{array}$ \\
\hline
\end{tabular}

\begin{tabular}{|l|l|}
\hline NOME DA INSTITUIÇÃO & \\
\hline RIDE/RA & \\
\hline PERÍODO & \\
\hline OBJETO DA PARCERIA & \\
\hline REALIZADO POR: & $\begin{array}{l}\text { ( ) CONVÊNIO } \\
\text { ( ) ACORDO } \\
\text { ( ) TERMO DE COOPERAÇÃO } \\
\text { ( ) OUTRO. INDIQUE_ }\end{array}$ \\
\hline
\end{tabular}

\begin{tabular}{|c|c|}
\hline NOME DA INSTITUICÃO & INSTITUTO PRÓ-MEDIACÃO \\
\hline RIDE/RA & BRASÍLIA \\
\hline PERÍODO & $2009-2012$ \\
\hline OBJETO DA PARCERIA & $\begin{array}{l}\text { COLABORAÇÃO TÉCNICA/PEDAGÓGICA, SEM EXIGÊNCIA DE } \\
\text { CONTRAPARTIDA }\end{array}$ \\
\hline REALIZADO POR: & $\begin{array}{l}\text { ( ) CONVÊNIO } \\
\text { ( ) ACORDO } \\
\text { (X ) TERMO DE COOPERAÇÃO } \\
\text { ( ) OUTRO. INDIQUE }\end{array}$ \\
\hline
\end{tabular}

9. AÇÕES E PARCERIAS DO PEAC COM OUTROS PROJETOS INSTITUCIONAIS

\begin{tabular}{|l|}
\hline O PEAC TEM PARCERIA COM \\
PROJETOS OU PROGRAMAS \\
INSTITUCIONAIS DA UNB \\
\hline O PEAC TEM PARCERIA COM \\
PROJETOS OU PROGRAMAS \\
INSTITUCIONAIS EXTERNOS A \\
UNB \\
\hline
\end{tabular}
(X) NÃO
( ) SIM, CITE:
( ) NÃ̃
( $X$ ) SIM, CITE: PARCERIA COM O NÚCLEO DE ENFRENTAMENTO
DAS VIOLÊNCIAS - NEVV/UNIVERSIDADE CATÓLICA DE
BRASÍLIA/PROJETO DE EXTENSÃO

7. PERFIL DA COMUNIDADE COM O QUAL O PROJETO / PROGRAMA TRABALHA

\begin{tabular}{|l|l|}
\hline NUMERO ESTIMADO DE PÚBLICO ENVOLVIDO & 5.700 (total de professores, alunos e servidores das três escolas). \\
\hline FAIXA ETÁRIA & $(\mathrm{X}) 0$ A $12(\mathrm{X}) 13$ A 20 (X) 21 A 60 ( ) ACIMA DE 60 \\
\hline COLETIVOS ORGANIZADOS \\
( ) ASSOCIAÇÕES, CITE: \\
( ) COOPERATIVAS, ITE: \\
( ) MOVIMENTOS SOCIAIS, CITE: \\
(X) ONGS. (1) CITE: MOVIMENTO CULTURAL SUPERNOVA/ SÃO SEBASTIÃO \\
(X) ESCOLA, CITE: CENTRO EDUCACIONAL SÃO FRANCISCO (SÃO SEBASTIA), CEF 02 (PARANOÁ), CEF 602 \\
(RECANTO DAS EMAS) E REGIONAL DE ENSINO DO GAMA. \\
\hline
\end{tabular}


FAZER CITAÇÃO BIBLIOGRÁFICA ABNT (AUTOR, TITULO, ANO, CIDADE, EDITORA ETC.) numere as citações e indique entre parêntese o tipo de produção.

ARTIGO: BELEZA, Flávia. Estudar em paz: mediação de conflitos no contexto escolar. Revista Participação, Universidade de Brasília, 2011.

PRODUÇÃO CULTURAL: (TIPO: SITE, DVD, BLOG, TWITTER, APRESENTAÇÕES ARTÍSTICAS, OUTROS). FAZER CITAÇÃO (AUTORES, TITULO, CIDADE, ANO, URL ETC.) numere as citações e indique entre parêntese o tipo de produção.

8) BLOG DO PROJETO ESTUDAR EM PAZ - http://estudarempaz.blogspot.com . Blog criado para divulgação das ações do projeto, em julho de 2009. O blog também é utilizado para compartilhar textos, vídeos, fotos, notícias e divulgar os eventos realizados pelo projeto. Administrado pela coordenação do projeto. Até a presente data, foram registradas 765 visualizações.

9) BLOG DOS MEDIADORES DO RECANTO DAS EMAS/DF: http://estudarempazcef602.blogspot.com. Blog criado pelos mediadores do CEF 602 do Recanto das Emas/DF, em agosto de 2011. O blog também é utilizado para compartilhar textos, vídeos, fotos do projeto. Administrado pelo Prof. Francisco Celso Leitão, coordenador do projeto no CEF 602 do Recanto das Emas e pelos mediadores da escola.

10) FACEBOOK - /estudarempaz. Criado e administrado pela coordenação do projeto para divulgar as ações e blogs do projeto. O facebook permite uma troca de informação mais ágil.

11) APRESENTAÇÕES ARTÍSTICAS (O projeto desenvolve uma ação de sensibilização - Mediação, Paz e Amor - , na qual uma banda com três músicos e os alunos mediadores da escola cantam, dançam e convidam a comunidade escolar para conhecer e participar das demais ações do projeto. Em 2011 o projeto realizou 3 festas: uma no CEF 02 (Paranoá/DF), em 30 de maio de 2011, uma no CED São Francisco (São Sebastião/DF), em 03 de junho de 2011, e a terceira no CEF 602 no Recanto das Emas/DF, em 16 de setembro de 2011.

12) PROGRAMAS DE TELEVISÃO -

5.1) Programa Alternativo - SBT/Brasília, mostra formatura dos mediadores do CEF 601, Recanto das Emas, turma de 2012. O programa foi ao ar em 17 de novembro de 2012.

Fonte: http://www.youtube.com/watch?v=RYo6OYEixHE

5.2) UNB/TV - Reportagem sobre o Projeto Estudar em Paz. A reportagem foi publicada em 13.12.2012.

Fonte: http://www.youtube.com/watch?v=jSN0xStS1E4

13) PROGRAMA DE RÁDIO - 24/05 - 9h - Reportagem para Rádio Brasil - Recanto, CEF 602 - participação de mediadores.

14) VÍDEOS DO PROJETO PUBLICADOS NO YOUTUBE. Após a formação em mediação, cada turma produz seu vídeo para publicar no Youtube. Os conflitos abordados nas simulações de mediação são escolhidos, roteirizados e ensaiados pelos mediadores, conforme a realidade de cada escola, sob a orientação da coordenação do projeto.

7.1- VÍDEO 7 - MEDIAÇÃO COLETIVA - QUALIDADE DO LANCHE NA ESCOLA. SIMULAÇÃO DE MEDIAÇÃO COLETIVA COM ALUNOS DO CEF 602, RECANTO DAS EMAS. (EM PROCESSO DE EDIÇÃO)

PROPOSIÇÃO DE CURSOS, MINICURSOS, OFICINAS, WORKSHOPS, DISCIPLINAS ETC. RELACIONADAS AO PROJETO. FAZER CITAÇÃO (TITULO, LOCAL DE REALIZAÇÃO, DATA, PROPONENTES ETC.) numere as citações e indique entre parêntese o tipo de produção.

CURSOS REALIZADOS PELA EQUIPE COORDENADORA E PELOS MEDIADORES FORMADOS PELO PROJETO:

- Curso de formação de mediadores para Orientadores Educacionais da regional de ensino de Samambaia, com 40 horas, de 09.12.2012 a 05.05.2012. (41 participantes).

- Curso de formação de mediadores para estudantes, no CEF 02, Paranoá/DF, com 40 horas. (14 participantes).

- Curso de formação de mediadores para estudantes, no CEF 411, Samambaia/DF, com 40 horas. (24 participantes).

- Curso de formação de mediadores estudantes, no CEF 02, Recanto das Emas, com 40 horas. (13 participantes).

PARTICIPAÇÃO EM CONGRESSOS, SEMINÁRIOS, FÓRUNS, ENCONTROS, MESA REDONDA ETC. FAZER CITAÇÃO (TITULO, CIDADE, DATA, CARÁTER DA PARTICIPAÇÃO - OUVINTE OU COMUNICADOR, ETC.) numere as citações e indique entre parêntese o tipo de produção.

1) I Seminário de Planejamento Participativo da Unidade de Internação de Planaltina. - UIP.

TEMA: "CONSTRUINDO METODOLOGIAS DE INTERVENÇÃO” .

CIDADE: Planaltina/DF

DATA: 14.02.2012 - Manhã.

OFICINA 3: Conflito e Crise: mediação social e gerenciamento de conflitos

FACILITADORA: Flávia Beleza - Advogada Mestre em Política

Social (UNB) e Especialista em Negociação, Mediação e Arbitragem.

SISTEMATIZAÇÃ̃: Luciana Genú - ARTS da UIP e Luana Alves Chefe do Sociopsicopedagógico da UIP. 
LOCAL: Universidade de Brasília - Campus de Planaltina - FUP

2) Roda de Conversa (Mesa Redonda) com Orientadores Educacionais de Samambaia e Grupo de Rio Preto (Assistentes Sociais e Psicólogos do Fórum de São José do Rio Preto).

TEMA: "MEDIAÇÃO SOCIAL NO CONTEXTO ESCOLAR: CAMINHOS E DESAFIOS".

CIDADE: Samambaia/DF

DATA:15.06.2012

ORGANIZAÇÃO: Projeto Estudar em Paz

PARTICIPANTES: Flávia Beleza, Yasmim Carneiro, Rafael Senda, Janaina Egler, Bárbara Vaz.

LOCAL: Sede da Regional de Ensino de Samambaia.

3) Palestra no Curso de Curso de Mediação para Orientadores na EAPE.

CIDADE: Brasília/DF.

TEMA: "MEDIAÇÃO SOCIAL NO CONTEXTO ESCOLAR".

DATA: 26/07

PALESTRANTE: Flávia Beleza

LOCAL: Escola de Aperfeiçoamento dos Profissionais da Educação - EAPE.

4) Palestra para Orientadores Educacionais do Guará.

TEMA: ““MEDIAÇÃO SOCIAL NO CONTEXTO ESCOLAR”.

CIDADE: Brasília/DF

DATA: $10 / 08$ - 9h

PALESTRANTE: Flávia Beleza

PARTICIPAÇÃO: Daniella Ovídio

LOCAL: Centro Educacional 03 do Guará II (Centrão da QI 19) (prof. Ailton).

5) Palestra para orientadores educacionais e professores na EAPE.

TEMA: "ESTRATÉGIAS DE MEDIAÇÃO DE CONFLITOS".

CIDADE: Brasília/DF

DATA: 04.10.2012 - Tarde.

PALESTRANTE: Flávia Beleza.

LOCAL: Escola de Aperfeiçoamento dos Profissionais da Educação - EAPE.

6) II Fórum Escola Cidadã: Responsabilidade de Todos.

TEMA: "MEDIAÇÃO SOCIAL"

CIDADE: Recanto das Emas/DF

DATA: 22.11.2012

PALESTRANTES: Flávia Beleza e Francisco Celso (Coordenador de Direitos Humanos e Diversidade/Recanto das Emas).

PARTICIPAÇÃO: Daniella Ovídio

LOCAL: Auditório do CREREMA - Recanto das Emas.

O PROJETO APRESENTOU ATIVIDADE (EXECENTUA-SE A EXPOSIÇÃO DE PÔSTER PIBEX) NA SEMANA UNIVERSITÁRIA 2012? SE SIM, INDIQUE O TITULO DA ATIVIDADE, MODALIDADE E PUBLICO DE INTERESSE

SIM. Mesa redonda sobre o projeto "Estudar em Paz", em ...., no Auditório do CEAM/UnB, para estudantes da UnB, professores, pessoas da comunidade e demais interessados.

9. PREMIAÇÕES RECEBIDAS PELO PROJETO / PROGRAMA DESDE A SUA CRIAÇÃO

10. RECURSOS FINANCEIROS

\begin{tabular}{|l|l|}
\hline O PEAC APRESENTA MOVIMENTAÇÃO FINANCEIRA & ( )SIM (X) NÃO \\
\hline SE SIM, IDENTIFIQUE A ORIGEM DOS RECURSOS & ( ) RECURSOS PRÓPRIOS \\
( ) RECURSOS EXTERNOS
\end{tabular}




\section{AVALIAÇÃO GERAL}

\section{OBJETIVOS PROPOSTOS}

OBJETIVO GERAL: Capacitar estudantes, professores, corpo técnico-administrativo e pais de alunos em mediação social no contexto escolar, visando a consolidar uma compreensão da mediação como instrumento para uma prática cidadã junto as escolas de rede pública de ensino do Distrito Federal.

O projeto "Estudar em Paz: Mediação de Conflitos no Contexto Escolar" é um Projeto de Extensão de Ação Contínua - PEAC da Universidade de Brasília/UnB, sob a coordenação do Núcleo de Estudos para a Paz e os Direitos Humanos - NEP.

OBJETIVO GERAL

O projeto tem como objetivo levar a proposta da mediação social para as escolas da rede pública de ensino do Distrito Federal, por meio da formação de mediadores/as sociais (alunos/as, professores/as, servidores/as, corpo técnico-administrativo e pais/mães e pessoas da comunidade) e da promoção dos valores da Cultura de Paz, dos direitos humanos, de justiça social e cidadania.

\section{OBJETIVOS ESPECÍFICOS:}

1 - Possibilitar a leitura de textos sobre mediação social, de modo a construir uma compreensão embasada em experiências bem sucedidas de transformação de conflitos no contexto escolar;

2 - Fomentar junto aos capacitandos práticas educativas pautadas na Cultura de Paz, direitos humanos, justiça e cidadania;

3 - Incentivar junto aos diferentes segmentos sociais a incorporação da prática da mediação como instrumento de diálogo e participação no contexto escolar;

4 - Supervisionar e acompanhar os alunos formados em mediação escolar na primeira etapa, nas atividades teóricas e práticas a serem desenvolvidas junto aos novos participantes inscritos no projeto.

5 - Difundir a experiência da mediação no contexto escolar do CED São Francisco junto à rede de ensino do Distrito Federal*. *Nos objetivos foram incluídas mais duas escolas e uma regional de ensino: o CEF 02 (Paranoá/DF), o CEF 602 (Recanto das Emas/DF) e a Regional de Ensino do Gama/DF.

\section{OBJETIVOS ALCANÇADOS}

Todos os objetivos do projeto foram alcançados. O momento é de aprimoramento da metodologia e amadurecimento do projeto, para continuar a sua difusão na rede pública de ensino do Distrito Federal.

\section{PRINCIPAIS DIFICULDADES}

罡 (D) No decorrer do trabalho, percebeu-se o divórcio que existe entre a escola e a comunidade, principalmente com a sua rede social local. Uma das ações do projeto é tecer a rede entre a escola, a família e a comunidade e promover os direitos de cidadania. Nesse sentido, os alunos bolsistas estão fazendo um mapeamento da rede social de proteção das três cidades do projeto (São Sebastião, Paranoá e Recanto das Emas) para melhorar o apoio às escolas. A maior dificuldade tem sido obter as informações necessárias das instituições públicas (Conselho Tutelar, Centro de Referência de Assistência Social-CRAS, Centro de Atenção Psicossocial- CAPS e outras), diante da precariedade dos registros, de recursos e de pessoal.

(D) A falta de recursos financeiros também dificulta a expansão do PEAC. As despesas com camisetas, festas, certificados, material pedagógico, deslocamentos e alimentação são custeadas pelos coordenadores do projeto.

QUAL É A FORMA DE ACOMPANHAMENTO DO PEAC E OS INSTRUMENTOS APLICADOS PARA AFERIÇÃO DE RESULTADOS JUNTO A COMUNIDADE

O PEAC PRETENDE CONTINUAR DESENVOLVEND O SUAS ATIVIDADES NA COMUNIDADE ATUAL? TEM PESPECTIVAS DE EXPANSÃO DE SUA ATUAÇÃO OU CONTINUIDADE DAS ATIVIDADES EM OUTRAS COMUNIDADES?

HOUVE INTERESSE DA COMUNIDADE NA PERMANENCIA DA ATUAÇÃO DO PEAC NA REGIÃO? 
O PEAC pretende continuar na mesma linha temática (DIREITOS HUMANOS E JUSTIÇA), principalmente pelo momento atual de descoberta da mediação de conflitos como instrumento de realização dos direitos humanos e da cidadania, nas escolas públicas do Distrito Federal.

\section{QUAIS SÃO AS PERSPECTIVAS DE POTENCIALIZAÇÃO DO TRABALHO DO PEAC COM OUTRAS} INICIATIVAS ACADEMICAS?CITE AS POSSIVEIS NOVAS PARCERIAS.

\section{RELAÇÃO UNIVERSIDADE/COMUNIDADE ENVOLVIDA NA CONSTRUÇÃO E DESENVOLVIMENTO DO PROJETO/PROGRAMA}

\begin{tabular}{|l|l|}
\hline & \\
\hline & \\
\hline & \\
\hline & \\
\hline
\end{tabular}

\section{RELATÓRIO 1}

\section{ATIVIDADES DA COORDENAÇÃO}

17/01 - Reunião com coordenadora do CAJE Planaltina e assessores - Apresentação do Projeto Estudar em Paz.

30/01 - Encontro com prof. Nair para fechamento do relatório de coordenador 2011.

31/01 - Entrega do Relatório de Coordenador e dos bolsistas do DEX.

09/02 - Primeira reunião do ano com extensionistas.

13/02 - Reunião no Paranoá - CEF 01 - com Marcelo (diretor) e equipe para apresentação do projeto. Ainda não dá para atender a escola.

14/02 - Palestra CAJE de Planaltina para socioeducadores da instituição.

15/02 - Reunião com Dra. Gilca e Lurdinha no DGP para falar das novas bolsas, acompanhando a Prof. Nair.

17/02 - Encontro com Flávia TImm na Católica para confirmar parceria com o Projeto Sankofa (projeto de extensão coordenado pela Flávia).

01/03 -9h - Reunião na EAPE/SUBEB com a gerente de educação básica (Prof. Érica)

14:30h - Reunião no Centrão/Taguatinga, com Flávia Timm, Maristela Gusmão e gestores da escola para falar do projeto.

07/03 -8 h e 14h - Palestras para professores da regional do plano piloto, professores da distorção (DIS), no auditório da escola 315 Sul.

08/03 - Entrevista ara Vicentina da Universidade Católica, mestrado em educação, que escreveu sobre o projeto.

09/03 -Início da formação dos Orientadores de Samambaia.

12/03 - Reunião na SEDH, com Flávia Timm, sobre editais de 2012.

14/03 - Reunião EAPE - Michelle, Ana Cláudia e Yara - Projetos de mediação no Gama.

16/03 - Formação Samambaia - módulo 2

20/03 - 16:30 h - Reunião na Católica com Flávia Timm - Projeto SEDH

28/03 - GT Mediação no NEP.

29/03 - 17h - Reunião Católica com Flávia Timm - Projeto SEDH

30/03 - Formação Samambaia - Abertura do Mediador

02/04 - Reunião na SUBEB com coordenadores - Projeto SEDH

02/04 - Publicação do Edital SEDH

03/04 - Reunião no Paranoá - CEF 02 - com Michelle e Pedro

06/04 - Formação Samambaia - Abertura do Mediador

13/04 - Formação Samambaia - Fases da Mediação

20/04 - 9h - Reunião na SUBEB - Projeto SEDH - Renata, Marta, Maraísa e Maristela.

24/04 - 17h - Reunião Católica com Flávia Timm - Projeto SEDH

26/04 - 9h- Palestra "Convivência Escolar: O desafio de educar para a democracia", com a Prof ${ }^{a}$ Dra. Joelle Bordet, pesquisadora francesa e especialista em "Violência e Juventude", no Centro de Convenções - Auditório Master, dia 26/04, das $9 \mathrm{~h}$ às $12 \mathrm{~h}$.

27/04 - Formação Samambaia - Fases da Mediação

04/05 - Formação Samambaia - Final - Mediação Social e EDH

07/05 - Fechamento Projeto SEDH para correção - Última versão

09/05 - 16h - Reunião SEDH com Vânia e Flávia Timm - fechar projeto

10/05 - 9:30 h - Reunião no Recanto - CEF 602 - com Francisco, Dani, Lucas e Bruna, Planejamento da ações para início dos trabalhos.

23/05 - Sensibilização professores do CEF 602 - Recanto. 
24/05 - 9h - Reportagem para Rádio Brasil - Recanto, CEF 602 - participação de mediadores.

14/06 - 14h - Chegada do pessoal de Rio Preto - Aula no Recanto das Emas

15/06 - Roda de Conversa com Orientadores Educacionais de Samambaia e Grupo de Rio Preto: educação, conflitos, violências e a proposta da mediação social.

26/07 - Participação no Curso de Mediação para Orientadores na EAPE - a convite de Michelle Confessor. Aula: Mediação Social no Contexto Escolar.

10/08 - 9h - Palestra para Orientadores Educacionais do Guará - "Mediação Social no Contexto Escola" Centro Educacional 03 do Guará II (Centrão da QI 19) (prof. Ailton).

23/08 - 10h - Missão Pedagógica no Parlamento - Auditório CEFOR -Câmara dos Deputados - presença dos extensionistas e participação de mediadores - Chicão apresentou projetos.

26/09 - 17h - Reunião Prof. Nair - Café das Letras - Propostas preliminar EDH na UnB.

04/10 - Palestra para Orientadores Educacionais de Taguatinga - Mediação Social no Contexto Escolar (convite Prof. Cléssia)

24/10 - Palestra na EAPE - "Estratégias de Mediação de Conflitos" - (convite prof. Cléssia).

22/11 - 8h - II Fórum Escola Cidadã: Responsabilidade de Todos. Tema: Mediação Social. Palestrantes: Flávia Beleza e Francisco Celso. Local: Auditório do CREREMA - Recanto das Emas.

\title{
RELATÓRIO 2
}

\section{Memória das Reuniões de Coordenação}

Data: 09/02/2012

Local: NEP (UnB)

Horário: $9 \mathrm{~h}$ às 11:30h

Coordenação: Flávia

Presentes: Thaís, Bárbara, Jéssica, Daniella, Gabriela, Rafael, Janaína, Francisca e Yasmim.

1 - Alunos ficaram de verificar a grade horária do primeiro semestre de 2012 para escolhermos o melhor dia para as coordenações semanais.

2 - Discussão sobre quais escolas ficarão no $1^{\circ}$ semestre. Em votação:

- CEF 602 - Recanto das Emas

- Centrão- Taguatinga

- São José- São Sebastião (esta escola é importante porque, de acordo com o fluxo, seus alunos vão para o Chicão).

- Chicão - São Sebastião

3 - Alunos farão o mapeamento da rede local, de forma mais completa. Foram divididos em grupos. Entrega: 27 de Abril.

- Recanto- Gabriela, Rafael, Jaísa

- Taguatinga- Ana Luiza, Bábara, Daniella

- São Sebastião- Yasmin, Thais

4 - Rafael, Thaís e Yasmim entregarão documentação para o DGP.

5 - Prof. Nair chegou às $11 \mathrm{~h}$.

- Falou do convênio da UnB com a Secretaria de Educação.

- A mediação nas escolas vai constar como um dos objetivos.

- Preparar objetivos para constar no convênio o mais rápido possível.

- Reunião marcada com a Dra. Gilca no dia 15/02 (levar objetivos e lista dos alunos do projeto).

- Marcar reunião com Luciana Amorim (Unesco). Em junho abrirão edital.

\author{
Data: 14/03/2012 \\ Local: NEP (UnB) \\ Horário: 19:00 \\ Coordenação: Flávia \\ Presentes: Thaís e Daniella. \\ 1 - Planejamento do GT (Grupo de Trabalho) para os profissionais da educação formados pelo projeto. \\ 2 - GT na última quarta-feira de cada mês. \\ 3 - Thais falou sobre o "blog escola". Vamos estudar o blog para vermos a possibilidade de participarmos. \\ 4 - Daniella fez relato sobre a reunião com os diretores no CEF 02, Paranoá. Planejamento do início da formação \\ da escola. \\ 5 - Parceria com a Católica. Ampliação do projeto.
}

Data: 03/04/2012 


\section{Local: NEP (UnB)}

Horário: 14:00

Coordenação: Flávia

Presentes: Thaís, Bárbara, Daniella, Gabriela, Rafael, Janaína, Yasmim e Luis.

1 - Histórico das últimas 3 semanas - estão fazendo o mapeamento e estudando os módulos.

2 - Possível parceria do NEP com as coordenações da SUBEB (Subsecretaria de educação básica).

3 - Parceria com a Católica- as oficinas da Flávia estão prontas.

4 - Formação dos orientadores de Samambaia começou em 09/03.

Estamos no módulo 4 (problematização do conflito). Alunos estão convidados a participar.

5 - Esclarecimentos sobre o mapeamento. Estão indo devagar. Flávia pediu dedicação ao mapeamento, indicando instituições e forma de entrar em contato.

6 - Flávia ficou de enviar os planos de aula das escolas por email.

\section{Data: 10/04/2012 Coordenação e Grupo de Estudos \\ Local: NEP (UnB) \\ Horário: 19:00}

Coordenação: Flávia Beleza e Flávia Timm

Presentes: Thaís, Bárbara, Daniella, Gabriela, Rafael, Janaína, Yasmim, Flávia Timm (turma de alunos da Flávia).

1 - Noticias das oficinas de cartazes no Paranoá. Tudo encaminhado.

2- Fotos para o blog: copiadas.

3 - Discussão sobre os materiais necessários para o projeto (edital).

Materiais: papelaria, gráfica, camiseta, projetores, netbooks, telas, microfone, caixa de som, filmadora, maquinas fotográficas...

4 - Alunos vão colaborar na tomada de preços para as tabelas do edital. Divididos em grupos, ficaram responsáveis pelas tabelas).

5 - Leitura de texto:

Gadotti: "Educação e Poder"

Educação como prática revolucionária (comentário de Daniella)

Educação e libertação (comentário de Rafael)

Tomada de posição do educador. Educação e neutralidade. (comentário de Flávia)

\section{Data: 17/04/2012}

Local: NEP (UnB)

Horário: 14:00

Coordenação: Flávia

Presentes:

1 - Tabelas do edital não estavam prontas. Daniella pediu atenção e trabalho bem feito.

2 - Prof. Nair estava presente e falou sobre o compromisso com o projeto. Pediu mais dedicação de todos diante da importância do projeto.

3 - Próxima aula: conflito e violência.

4 - Confirmação dos dias de formações nas escolas:

- $\quad$ Recanto - quinta-feira à tarde.

- Paranoá - quarta-feira à tarde.

Data: $24 / 04 / 2012$

Local: NEP (UnB)

Horário: 14:00

Coordenação: Flávia

Presentes:

1 - Fechamento das tabelas do edital com todos os grupos.

Data: 03/05/2012

Local: NEP (UnB)

Horário: 14:00

Coordenação: Flávia

Presentes:

1 - Proposta de sarau no Chicão, no dia 11, para apresentação da mediação:

- música

- $\quad$ apresentação de atividades 
- $\quad$ procura de artistas para o sarau

- fechamento de programação na próxima terça-feira

2 - A greve das escolas acabou:

- $\quad$ preparar cartazes para início das formações

- $\quad$ ver datas das formações nas escolas: cada grupo vai procurar sua diretoria.

3 - Mapeamento:

1.Levar informações para as escolas.

2.Entrevistar orientadores e direção.

3.Criação de laços entre a rede e a escolas: palestras, oficinas, visitas...

4. Planejar novas ações a partir do mapeamento.

4 - Diálogo sobre conflito positivo e violências invisíveis.

Data: 08/05/2012

Local: NEP (UnB)

Horário: 14:00

Coordenação: Flávia

Presentes:

1 - Formação no Chicão - segundas à tarde (Thais e Yasmim)

2 - Escolha do vídeos para passar sexta no chicão

- $\quad$ Pro dia nascer feliz: (assistiram na coordenação e fizeram comentários)

- Preciosa: foi assistido pelos bolsistas no cinema

- A onda: ninguém assistiu e é difícil conseguir em locadoras. Vão procurar.

3 - Chicão-Oficina:

- Filme - "Pro dia Nascer Feliz"

- $\quad$ intervalo: musica e apresentação da mediação

4- Ínicio das aulas nas escolas a partir do dia 21/05

5-Estudar módulos e fazer slides para o próximo encontro. Planejar aulas.

Data: $22 / 05 / 2012$

Local: NEP (UnB)

Horário: 14:00

Coordenação: Flávia

Presentes:

1 - Revisão das aulas - foram passados vídeos e slides no auditório do CEAM. Módulo I - O conflito

2 - Foi repassada a dinâmica para a primeira aula: guerra de braços.

3 - Distribuição das balas para as turmas - comprar e dividir com os grupos.

Data: 29/05/2012

Local: NEP (UnB)

Horário: 14:00

Coordenação: Flávia

Presentes:

1 - Avaliação do início das formações nas escolas:

Paranoá: os alunos foram participativos; não tiveram uma sala adequada no primeiro encontro (brincaram no chão). Falaram com o Pedro para providenciar sala e equipamento para vídeos.

Recanto: alunos participativos; muitas pessoas na sala (5 alunos da UnB, 6 alunos da Católica e 28 alunos).

Chicão: além dos alunos, registraram a presença de 3 professores na formação. Não gostaram da presença dos professores.

2 - Revisão do módulo I - O conflito.

3 - Os bolsistas pegaram o conteúdo (módulo II e os vídeos) para o próximo encontro.

Data: 05/06/2012

Local: NEP (UnB)

Horário: 14:00

Coordenação: Flávia

Participantes:

1 - Relatos da aplicação do Módulo I (O conflito) nas escolas:

Paranoá: 
- Fizeram a dinâmica da "cultura de paz" - os alunos adoraram.

- Compraram pastas para os alunos, contendo: programa, folhas em branco e caneta.

- $\quad$ Número de alunos se manteve.

- Chegaram ao objetivo pretendido.

Recanto:

- $\quad$ Teve ensaio da quadrilha no mesmo horário da formação, o que atrapalhou.

- $\quad$ Boa participação do pessoal da católica.

- $\quad$ Alcançaram o objetivo.

Chicão:

- $\quad$ O grupo compreendeu o conflito e como a mediação transforma os conflitos.

Alunos gostaram dos vídeos.

- $\quad$ Alunos citaram que há mais conflitos com os professores na escola.

Professores presentes rebateram falando de alunos desinteressados.

- Não gostaram da presença da professora de filosofia na aula, não entendeu a proposta.

2 - Diálogo com os extensionistas: o que seria uma "aula interessante"?

Respostas: "aula rica em debates"; "aula que tenha a ver com a realidade deles"; "falta um pouco de concreto e sair do abstrato"; mudar a forma como passam a matéria, como contam a história"; "as aulas podem ser produtivas e prazerosas"...

3 - Foi repassado o conteúdo do Módulo II - Violência

Data: 19/06/2012

Local: NEP (UnB)

Horário: 14:00

Coordenação : Flávia

Presentes:

1 - Resumo do módulo II, enviado na semana passada.

2 - Relatos da formação nas escolas, módulo II:

Chicão:

- A religião e a homossexualidade geraram polêmica. Acham que eles entenderam a mensagem.

Paranoá:

- $\quad$ Tudo bem, não houve polêmica. Foi feita uma dinâmica da CONFIANÇA e os alunos gostaram. Estão usando a criatividade.

Recanto:

- Não houve polêmica. Quando os mediadores já formados estão presentes os que estão se formando participam mais.

- Dani acha que falou muito e fez poucas perguntas. Vai perguntar mais.

Data:26/06

Local: NEP (UnB)

Horário: 14 Horas

Coordenação: Flávia

Presentes:

1 - Revisão do Módulo III - A mediação social e o mediador.

- Orientações da Flávia para passar bem o conceito de mediação social:

Mediação social cria laços sociais para a transformação dos conflitos.

- O mediador precisa reconhecer o conflito antes de tudo, e eles são capazes de reconhecer todos os conflitos.

- Deixar claro qual é o principal papel do mediador é criar laços.

- Mostrar vídeos da abertura do mediador, para facilitar o entendimento.

- E por fim, deixar claro para os meninos que é importante trabalhar sempre com a pergunta e nunca entregar a resposta pronta.

Data:03/07

Local: NEP (UnB)

Horário: 14 Horas

Coordenação: Flávia

Presentes: 
1 - Foram reforçadas todas as orientações para abertura do mediador, pois é um passo imprescindível da mediação. Repassado o passo 1 das fases da mediação e o passo 2. 2 - Arrumação da sala e posição da mesa.

Datas: 10/07 à 17/07 - Período de Recesso

(ver registros de 24/07, 31/07, 07/08 e 14/08 - estão faltando)

Data: 21/08/12

Local: NEP (UnB)

Horário: 14 Horas

Coordenação: Flávia

Presentes: Rafael, Daniella, Thaís, Flavia, Janaína, Gabriela, Carlione, Bárbara, Ana Luísa, Yasmin, Ana Paula, Larissa

Pauta do dia:

1 - Providenciar material para ser utilizado nas mandalas.

2 - Orientações para a etapa do fechamento da mediação: (ex.) se quiser ter uma próxima mediação, é possível. Propor práticas que discutam a relação aluno/professor.

3 - Logo depois, distribuir a ficha que contem a funçao do mediador social e "para ter o espirito mediador", explicar a função do mediador, ler todos os itens, para que se tenha uma retrospectiva da mediação e que ajude nas ideias para as mandalas.

\section{Data: 09/10/12}

Local: NEP (UnB)

Horário: 14 Horas

Coordenação: Flávia

Presentes: Rafael, Daniella, Thaís, Flavia, Janaína, Gabriela, Carlione, Bárbara, Ana Luísa, Yasmin, Ana Paula, Larissa.

1 - Relato da festa "Paz e Amor" do Paranoá.

O grupo está frustrado com a falta de organização da festa, não se prepararam como deveriam. Faltaram equipamentos. Vão fazer uma lista para a próxima vez. Flávia ponderou que é assim que aprendemos, fazendo. Cada vez vai ficando melhor. Os componentes do grupo têm que melhorar a comunicação e planejar tudo com antecedência. Thais sugeriu falar com os músicos para saber das necessidades deles e fazer uma lista padrão. Mas a festa foi um sucesso, os alunos tomaram conta, tocaram e cantaram.

2 - Fazer um formulário para pais autorizarem fotos dos filhos para o facebook do projeto.

3-Sugestões de quais estudantes/áreas precisamos para o projeto: cinema, educação, música, cênicas.

4-Pensar no acabamento das salinhas de mediação: pintura, mesas, cadeiras...

5-CArlione vai pensar em opções para enfeitar as salinhas de mediação.

6 - Flávia vai enviar por email os formulários de atendimento.

7 -Pensar nos artigos para o final do ano.

Data: 20/11/12

Local: NEP (UnB)

Horário: 14 Horas

Coordenação: Flávia

Presentes: Rafael, Daniella, Thaís, Flavia, Janaína, Gabriela, Carlione, Bárbara, Ana Luísa, Yasmin, Ana Paula, Larissa.

1 - Verificar que dia termina o calendário escolar para encerrarmos as atividades.

2 - Ideias para os vídeos:

Recanto: problema com o lanche (sem refeitório, falta de higiene, questão da qualidade).

Paranoá: questão da sexualidade.

3 - Propor vídeo sobre violência estrutural para todas as escolas.

4 - Procurar editais para a compra de equipamento próprio.

5-Ligar para Samambaia e propor filmagem lá.

6- Encerramento do ano: encontro de mediadores na UnB. Ver transporte para os alunos.

7-Coordenação para avaliação geral marcada para 04/12.

Data: 27/11/12

Local: NEP (UnB)

Horário: 14 Horas 


\section{Coordenação: Flávia}

Presentes: Rafael, Daniella, Thaís, Flavia, Janaína, Gabriela, Carlione, Bárbara, Ana Luísa, Yasmin, Ana Paula, Larissa

1 - Fazer relatório de atividades para a prof. Nair. Todos devem fazer relatório individual. Entregar até o final do mês de dezembro.

2- Procurar parceria com a UnB TV.

3- Reunião no Recanto com a direção - quinta (29) às 13:30.

4- Pesquisar opções de lazer e cultura no Recanto, para o vídeo.

5-Sugestões para os vídeos (conflitos, locais de filmagem, falas...)

6-Buscar informações sobre "Comunicação Comunitária" na UnB.

\section{Data: 04/12/12}

Local: NEP (UnB)

Horário: 14 Horas

Coordenação: Flávia

Presentes: Rafael, Daniella, Thaís, Flavia, Janaína, Gabriela, Carlione, Bárbara, Ana Luísa, Yasmin, Ana Paula, Larissa

1 - Avaliação do projeto.

Flávia fez a abertura relatando as atividades da coordenação, que começaram em fevereiro. A greve atrapalhou bastante o cronograma de atividades nas escolas, que começaram no final de maio. Conseguiram formar uma turma de alunos em cada escola, mas não formaram professores, pois tinham pouco tempo para colocar suas tarefas em dia. Apesar disso, a parceria com a EAPE se consolidou, a regional do Recanto das Emas vai sugerir o projeto em todas as suas escolas e o projeto foi bastante divulgado nas diversas palestras. As festas foram um sucesso, apesar de alguns ficarem inseguros. As atividades artísticas da Carlione vieram abrilhantar o projeto. Mas como ela veio no final do ano, precisamos organizar melhor as atividades para o próximo ano. Como cresceu, o projeto precisa de mais organização para atender melhor as escolas e os extensionistas. Os extensionistas foram divididos em grupos por regional, outros vão ficar no NEP para organizar material, agenda, memória e outros registros. A coordenação precisa melhorar na organização dos registros das reuniões de coordenação e do material didático-pedagógico, pois as equipes precisam desse material com antecedência. Um bom arquivo digital será providenciado. Com a entrada da Bárbara Diniz, a coordenação deve melhorar bastante, pois a parte burocrática e a relação Projeto/NEP/UnB precisa de mais atenção. O projeto necessita de recursos para realizar melhor suas atividades.

Daniella relatou que tivemos problemas com o tamanho da equipe, que aprendemos com a prática e que se sentiu sobrecarregada. Alguns membros do grupo não foram participativos. Sentiu que a direção da escola esteve disponível, mas que não aproveitaram essa disponibilidade. Pretendem fortalecer esse laço com a direção no ano que vem. Achou que os alunos da $6^{\circ}$ série são imaturos, que temos que trabalhar com a $7^{a}$ série. Sugere que as atividades comecem logo no início do ano, mesmo com greve. O grupo grande é um privilégio, mas temos que nos organizar. A coordenadora reconheceu a sua enorme dedicação ao projeto.

Carlione se disse satisfeita com o trabalho realizado nas escolas. A resposta dos alunos é imediata. Gosta muito de trabalhar com crianças e espera colaborar muito com o projeto em 2013. A coordenadora adorou suas sugestões e seu entendimento da proposta do projeto. Isso vai se refletir na arte produzida pelos alunos.

Larissa confirmou a sua vocação depois de entrar para o projeto: quer mesmo ser professora, mas agora, uma professora diferente. Adorou o trabalho realizado no Recanto. Foi elogiada pela coordenadora pelo seu desempenho em sala de aula. Desinibida e boa comunicadora.

Rafael ressaltou a transformação que os alunos mediadores sofrem durante a formação, especialmente o aluno Marcelo, do Paranoá. De aluno cabisbaixo, criou autoestima e descobriu que tem qualidades. Isso, diz, Rafael, é muito gratificante. Disse que precisamos incentivar a formação do grêmio estudantil nas nossas escolas, melhorar os laços com os alunos e os gestores da escola, que faltou foco no projeto, pois as atividades acadêmicas são muitas, que vai organizar a vida pessoal para se dedicar mais, que devemos pensar num calendário de atividades contando com a greve do próximo ano.

Bárbara e Janaína, do grupo de Rafael, concordaram que precisam se comunicar melhor e se organizarem para as atividades na escola.

Thais falou sobre a organização e que vai assumir o registro virtual do projeto. Ela e Yasmim encontraram dificuldades para formar alunos do ensino médio, pois muitos trabalham no turno contrário. A coordenadora sugeriu que a formação aconteça no horário das aulas, talvez nas aulas de PD (parte diversificada).

Nathanael, ex-aluno do Chicão e mediador para sempre, estava presente e colaborou com a avaliação. Perguntado sobre a nossa forma de "dar aula", que apontasse o que era bom ou ruim, respondeu que a linguagem era o mais importante, e que nós estamos bem. Que podemos diminuir a parte teórica, porque a simulação dos conflitos é a parte mais legal. Os vídeos para discussão também são legais.

E nada mais foi dito. 


\section{RELATÓRIO 3}

Avaliação da coordenadora executiva:

Apesar das atividades do projeto terem se iniciado em fevereiro (ainda que em janeiro as atividades de edição dos vídeos não tenham parado), o projeto sofreu com a greve das escolas públicas e da UnB. O objetivo era formar uma turma de alunos, uma de professores e uma de pais em duas escolas (Paranoá e Recanto) e uma turma de alunos no Chicão. As turmas de pais e professores ficaram prejudicadas. Não conseguimos formar nenhuma, pois a greve deixou as escolas com meio ano e os professores atordoados. Em 2012, com exceção do CEF 411 de Samambaia, as escolas deram pouca atenção ao projeto. As greves atrapalharam demais o desenvolvimento das nossas atividades.

Para minimizar a frustração, uma nova escola entrou para o projeto, o CEF 411 de Samambaia, por esforço da orientadora educacional, que fez o curso em Samambaia e resolveu formar seus alunos. Colaboramos como pudemos, assumindo as aulas finais. Em 3 escolas encerramos as formações com a festa "Paz e Amor": CEF 602 do Recanto, CEF 02 do Paranoá e CEF 411 de Samambaia.

Os núcleos de mediação de 3 escolas estão em processo de estruturação (o do Chicão já está pronto): o do Recanto está em obras (será de madeira), o do Paranoá foi trocado e falta somente a porta (que está sendo providenciada) e o de Samambaia ainda não foi decorado pelos mediadores. Vamos conseguir nosso espaço em todas as escolas, com paciência, pois não há salas sobrando.

Temos que registrar a formação de 42 orientadores educacionais da regional de Samambaia. Ótima formação, com excelente participação. Os orientadores educacionais são nosso aliados naturais, pela afinidade entre as atividades. Outro ponto bastante positivo foi a aceitação do projeto pela Regional do Recanto das Emas, que pretende levá-lo para todas as suas escolas.

Em 2012, as formações aconteceram em 4 escolas: Chicão (São Sebastião), CEF 02 do Paranoá, CEF 602 do Recanto e CEF 411 de Samambaia. Os extensionistas receberam a formação em mediação social e foram divididos em grupos para as formações de estudantes nas escolas, assim divididos:

1) Chicão (São Sebastião): Yasmin, Thaís e Flávia - As meninas foram formadas ainda no Chicão e são mediadoras experientes. Realizaram um ótimo trabalho, apesar de lidarem com o ensino médio. A maioria da turma trabalhava no turno contrário, o que dificultou a formação. A sugestão é formar apenas durante o turno das aulas, não no turno contrário. A resistência dos professores e a pouca colaboração deles não permitirá a continuação do projeto nessa escola, em 2013. Após quatro anos, digamos que vamos "dar um tempo", pois o Chicão está em nossos corações para sempre.

2) CEF 02 do Paranoá: Janaína, Bárbara e Rafael - Grupo bastante unido e criativo. Espontaneamente, compraram material para seus alunos (pastas, blocos, canetas) e criaram atividades lúdicas para as aulas. Solidários e amigos. A dificuldade se deu pela inexperiência de lidar com alunos tão jovens (11 a 15 anos) e tão danadinhos. Mas conseguiram ir até o final, criaram laços afetivos com os alunos e se sentiram realizados com a experiência. A direção apoia o projeto, mas não colaborou na disponibilização do material multimídia nem de sala para a formação. A sugestão é dialogar mais com a direção e aumentar o comprometimento com o projeto.

3) CEF 602 do Recanto: Daniella, Ana Luisa, Gabriella e Larissa. Com participação dos alunos da Católica (da Flávia Timm), as aulas no Recanto foram uma festa. Daniella coordenou os trabalhos muito bem, tomando a frente na maioria das atividades. Mediadora social de mão cheia. A dedicação do grupo possibilitou a criação de laços com alunos que não participaram da formação, mas que colaboraram com a proposta cultural do projeto. Larissa, da pedagogia, encontrou a sua vocação e pretende escrever sobre o projeto em sua monografia. Ótima colaboradora. O grupo só precisa dividir melhor suas responsabilidades para não sobrecarregar alguns de seus membros.

4) CEF 411 de Samambaia - Daniella e Flávia. A formação teve início na metade do ano, quando a orientadora solicitou a nossa presença, pois estava com dificuldades para dar as aulas sozinha. Assumimos a formação e o trabalho foi realizado dentro do esperado. Uma turma ótima com 24 estudantes muito participativos. Vamos continuar o trabalho no ano que vem. A escola está de portas abertas para o projeto.

As atividades artísticas da Carlione vieram abrilhantar o projeto. Fizemos atividades com mandalas e de pinturas em 3 escolas (Chicão não participou). Como ela entrou no final do ano, ainda vamos pensar e organizar as atividades para o próximo ano. Os quadros que ela produz, mostrando a realidade da sua comunidade e o papel do cidadão nesse contexto, guiará nossas atividades. O Arthur, das Artes Cênicas, veio para somar na parte teatral no projeto. A ideia é produzir peças que representem a mediação social com os alunos nas escolas e apresentá-las em eventos.

No geral, observamos que o projeto precisa de mais organização para atender melhor as escolas e os extensionistas. Então, alguns extensionistas vão atuar nas escolas, enquanto outros vão ficar no NEP para organizar material, agenda, memória e outros registros. Isso só foi possível graças à entrada de novos bolsistas no projeto, uma necessidade antiga.

A coordenação precisa melhorar, também, a organização dos registros das reuniões de coordenação e a produção do material didático-pedagógico, pois as equipes precisam desse material com mais antecedência. Os grupos 
receberam pastas com os planos de aula e os módulos impressos, mas feitos em cima da hora. Como o material está pronto, tudo será mais bem realizado.

Recentemente, as coordenações semanais passaram a ser mais participativas, com pautas construídas coletivamente. Até o dia anterior de cada encontro, as sugestões para a pauta são postadas no facebook. Assim todos se preparam melhor para as reuniões. A iniciativa está surtindo um efeito positivo. Vamos aperfeiçoando nossa participação.

Um bom arquivo digital está sendo providenciado pela Thaís. Nesse arquivo teremos, em breve, todos os nossos documentos digitalizados, como atas, fotos, vídeos e outros registros. Também arquivaremos textos de interesse do projeto, artigos, capítulos de livros e notícias referentes à mediação.

A Rafaela e a Yasmim cuidarão dos registros junto ao NEP: arquivos, pastas, material pedagógico, atas, documentação dos extensionistas. Rafaela e Carla, sempre disponíveis para as nossas solicitações urgentes, continuarão nos apoiando no NEP. Com a entrada da Bárbara Diniz, a coordenação recebe um apoio importante, pois a parte burocrática e a relação Projeto/NEP/UnB precisa de mais atenção. Muitas das nossas necessidades podem ser atendidas na própria universidade, mas precisamos descobrir os caminhos.

A parceria com as professoras da Católica, iniciada em 2012, não continuará em 2013, por decisão pessoal da coordenadora do projeto SANKOFA, que pretende se dedicar a atividades não acadêmicas. Como a parceria era com os projetos das professoras, que não contam com o apoio necessário da sua instituição para continuar, tiveram que interromper a parceria. Infelizmente. Mas aprendemos muito com a Flávia Timm, a Maristela Gusmão e seus alunos. Um deles ficou, o Carlos, que tem colaborado e ainda vai colaborar muito conosco, especialmente na organização de eventos (seminários, palestras, oficinas). Essa parceria reforça a nossa crença na criação de laços para o desenvolvimento do projeto, mesmo fora da universidade.

Retrospectiva:

- O projeto não realizou alguns objetivos esperados para 2012 em virtude das greves, mas andou bastante. Não formamos turmas de pais e professores, mas ganhamos uma nova escola e uma regional inteira (Recanto das Emas).

- A coordenação precisa melhorar a comunicação e organizar melhor o tempo e as atividades. Foi o primeiro ano com a participação de muitos estudantes no projeto, sem nenhum conhecimento em mediação (exceto 3 estudantes) e nunca tinham dado aula. Em um ano eles foram formados e assumiram a formação nas escolas. Foi difícil, com momentos de angústia, mas conseguimos.

- Precisamos aprender a coordenar um grupo grande, melhorar a organização geral e os nossos registros. A entrada de novos membros para essas funções já mostra uma boa diferença. Tudo está sendo "auditado" e digitalizado para ser bem registrado.

- O projeto cresceu e os extensionistas precisam se comunicar melhor e se organizarem para conciliar as atividades do projeto com as atividades acadêmicas. Mas estão indo muito bem, cada um com seu tempo e seu talento.

- Não realizamos o objetivo de integrar as escolas com as redes sociais locais. Falta gente para trabalhar nesse objetivo, mas não vamos desistir.

- Os/as extensionistas entraram no projeto e demoraram um pouco para entender a proposta, que é totalmente dialógica e participativa. Eles e elas foram percebendo que o projeto está em constante transformação e que são sujeitos dela. Passado o susto, se sentem donoslas do projeto, que é o que queremos. A relação entre todos é absolutamente horizontal e respeitosa. Além disso, o afeto nos uniu.

Perspectivas:

- Começar o ano com um calendário de atividades ininterrupto, mesmo com uma possível greve. Pretendemos formar duas turmas de alunos em cada escola, uma de professor e uma de pais. (Recanto, Paranoá e Samambaia). - Formar mais orientadores nas regionais e na EAPE- a parceria continua.

- Melhorar a organização geral do projeto, designando pessoas voltadas exclusivamente para essa atividade.

- Realizar Seminário sobre Mediação Social no primeiro semestre e curso com apoio da UnB.

- Investir na divulgação do projeto pela internet (blog, facebook...)

- Reforçar a parceria com a EAPE e a SUBEB, com cursos de formação e palestras.

- Colaborar com o Prof. Francisco, do Recanto das Emas, para levar o projeto para toda a Regional. Estreitar os laços com o pessoal da Regional do Recanto.

- Tecer a rede entre as escolas e as instituições sociais do Estado e outras.

- Publicar artigos, um livro e duas cartilhas do projeto.

- Adquirir material permanente para as 04 equipes do projeto e para o NEP.

- Comemorar o quinto ano do projeto, com muitas parcerias e realizações.

Desafios para 2013: 
- Buscar recursos para adquirir material permanente (editais). É uma necessidade urgente conseguir material didático e de multimídia.

- Um grande desafio para 2013 será atualizar o mapeamento das redes para criar ou estreitar os laços entre elas e as nossas escolas. É um objetivo que precisamos perseguir, mesmo reconhecendo que é o mais difícil.

- Publicar artigos sobre o projeto é outra meta desafiadora, mas precisamos persegui-la.

- Comemorar o quinto ano, com ou sem recursos financeiros. Fazer a divulgação do quinto ano com cartazes, banners, folders...

A demanda pelo projeto é crescente, motivo pelo qual precisamos nos organizar melhor para dar mais visibilidade ao projeto, que comemorará seu quinto ano em 2013!

Para concluir, cabe ressaltar a dedicação dos extensionistas ao projeto, jovens conscientes, solidários e comprometidos. Usam seus próprios recursos, muitas vezes, para comprar material de papelaria, abastecer os seus carros para irem às diversas regionais, custear lanches e passeios com os alunos mediadores. Os grupos se prestigiam, visitam uns aos outros, colaboram em aulas coletivas e festejam os progressos de todos. São estudantes muitos especiais e serão profissionais diferentes: profissionais cidadãos.

Brasília, 19 de dezembro de 2012. 


\section{ANEXO C - RELATÓRIO PARCIAL DE COORDENADOR PROJETO E PROGRAMA DE EXTENSÃO \\ 2014}

(DigitaR E ENTREGAR ASSINADO, VIA UnBDoc, À DIRETORIA TÉCNICA DE EXTENSÃO - DTE / DEX)

IDENTIFICAÇÃO DO PROJETO

\begin{tabular}{|c|c|}
\hline $\begin{array}{l}\text { MODALIDADE DE EXTENSÃO } \\
\begin{array}{l}\text { (X) PROJETO }(\quad) \text { PROGRAMA }\end{array}\end{array}$ & 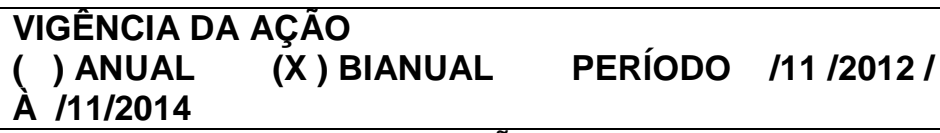 \\
\hline TÍTULO DA ATIVIDADE DE EXTENSÃO & $\begin{array}{l}\text { ESTUDAR EM PAZ - MEDIAÇÃO DE CONFLITOS NO } \\
\text { CONTEXTO ESCOLAR }\end{array}$ \\
\hline UNIDADE DE ORIGEM & $\begin{array}{l}\text { NÚCLEO DE ESTUDOS PARA A PAZ E OS DIREITOS } \\
\text { HUMANOS - NEP }\end{array}$ \\
\hline ÁREA TEMÁTICA PRINCIPAL & DIREITOS HUMANOS E JUSTIÇA \\
\hline COORDENADOR (A) & NAIR HELOISA BICALHO DE SOUSA \\
\hline TELEFONE & $9114-5282$ \\
\hline EMAIL & NAIR.BICALHO@GMAIL.COM \\
\hline
\end{tabular}

AVALIAÇÃO DOS PROCESSOS INSTITUCIONAIS

QUANTO À FORMULAÇÃO DO PROJETO:

INDIQUE A MOTIVAÇÃO PARA A CRIAÇÃO DO PROJETO

O PROJETO FOI CRIADO PARA PROMOVER A EDUCAÇÃO E A CULTURA EM DIREITOS HUMANOS E A CULTURA DE PAZ NAS ESCOLAS DA REDE PÚBLICA DE ENSINO DO DISTRITO FEDERAL, POR MEIO DA MEDIAÇÃO SOCIAL, EM ATENDIMENTO ÀS DIRETRIZES DO PLANO NACIONAL DE DIREITOS HUMANOS 3 E DO PLANO NACIONAL DE EDUCAÇ̃O EM DIREITOS HUMANOS. A EDUCAÇÃO EM DIREITOS HUMANOS É CONSIDERADA UM CANAL ESTRATÉGICO PARA PRODUZIR UMA SOCIEDADE MAIS JUSTA E IGUALITÁRIA. AO MESMO TEMPO, O PROJETO PROMOVE A EDUCAÇÃO PARA A PAZ E OS DIREITOS HUMANOS NA UNIVERSIDADE, TRANSFORMANDO ESTUDANTES UNIVERSITÁRIOS EM AGENTES DE TRANSFORMAÇÃO SOCIAL, MAIS PARTICIPATIVOS E SOLIDÁRIOS, COMPROMETIDOS COM A CIDADANIA E A JUSTIÇA SOCIAL.

JUSTIFIQUE A ESCOLHA DE ATUAÇÃO NA REGIÃO E COMUNIDADE INDICADAS

AS ESCOLAS PARTICIPANTES DO PROJETO SÃO SELECIONADAS A PARTIR DE UM CONJUNTO DE CRITÉRIOS: NECESSIDADE DA ESCOLA (CONFLITOS, VIOLÊNCIAS, DEGRADAÇÃO DAS RELAÇÕES), VULNERABILIDADE DA COMUNIDADE (FRAGILIDADE DA REDE DE PROTEÇÃO E ASSISTÊNCIA SOCIAL, AUSÊNCIA DE SERVIÇOS PÚBLICOS ESSENCIAIS, REGIẪO DE TRÁFICO DE DROGAS...), COMPROMETIMENTO DA DIREÇÃO E DA ORIENTAÇÃO EDUCACIONAL COM AS MUDANÇAS PROPOSTAS, TEMPO DE ESPERA PELO PROJETO E CAPACIDADE DA EQUIPE DO ESTUDAR EM PAZ EM ATENDER (CONFORME O NÚMERO DE EXTENSIONISTAS E VOLUNTÁRIOS).

EM 2013, O PROJETO FOI EXECUTADO NO CEF 602 DO RECANTO DAS EMAS, NO CEF 411 DE SAMAMBAIA/DF E NA ESCOLA CLASSE 22 DO GAMA/DF. JÁ TRABALHAMOS NA REGIONAL DO RECANTO DAS EMAS DESDE 2010, UMA PARCERIA QUE TEM RENDIDO BONS FRUTOS. A ESCOLHA DO CEF 411 SE DEU POR SOLICITAÇÃO DA ORIENTADORA EDUCACIONAL DAQUELA ESCOLA, UMA VEZ QUE A MESMA ESTÁ LOCALIZADA NUMA REGIÃO ONDE PREPONDERA O TRÁFICO DE DROGAS, REALIDADE QUE GERA VIOLÊNCIA DENTRO DA ESCOLA E NO SEU ENTORNO. A ESCOLA CLASSE 22 DO GAMA ESTAVA NA 
ESPERA POR UMA OPORTUNIDADE DE DESENVOLVER O PROJETO DESDE 2010. A ESCOLA RECEBE ALUNOS E ALUNAS DO NOVO GAMA (REGIÃO POBRE DO ENTORNO DO DF) E A ORIENTADORA EDUCACIONAL, FORMADA EM MEDIAÇÃO SOCIAL PELO PROJETO EM 2010, JÁ TRABALHAVA COM A PROPOSTA DO PROJETO COM OS ALUNOS DO ENSINO INFANTIL. SOMENTE EM 2013 O PROJETO CONTOU COM UM NÚMERO SUFICIENTE DE ALUNOS EXTENSIONISTAS PARA ATENDÊ-LA. MAS O PROJETO NÃO ACONTECE APENAS NAS ESCOLAS SELECIONADAS. OUTRAS AÇÕES SÃO DESENVOLVIDAS EM ESCOLAS DE OUTRAS REGIONAIS DE ENSINO E NA ESCOLA DE APERFEICOAMENTO DOS PROFISSIONAIS DA EDUCAÇÃO - EAPE, COMO PALESTRAS, SEMINAُRIOS, OFICINAS, FORMAÇÕES, TUDO EM PARCERIA COM A SECRETARIA DE EDUCAÇÃO DO DISTRITO FEDERAL. ULTIMAMENTE, O PROJETO ULTRAPASSOU AS FRONTEIRAS DO DISTRITO FEDERAL, DESENVOLVENDO AÇÕES EM MUNICÍPIOS DO ESTADO DE SÃO PAULO E EM GOIÁS. A DEMANDA PELO PROJETO É CRESCENTE.

HOUVE ENVOLVIMENTO DO COORDENADOR DE EXTENSÃO DE SUA UNIDADE?

(X)SIM ( )NÃO

JUSTIFIQUE

A COORDENADORA DE EXTENSÃO PROMOVE UMA GESTÃO PARTICIPATIVA E DIALÓGICA, ESTIMULA O ENVOLVIMENTO DE TODOS NO PLANEJAMENTO DE METAS E AÇÕES, ACOMPANHA ATENTAMENTE O DESENVOLVIMENTO DE TODAS AS AÇÕES DO PROJETO, ZELA PELO CUMPRIMENTO DOS OBJETIVOS E O APRIMORAMENTO DOS RESULTADOS PRETENDIDOS.

HOUVE DISCUSSÃO SOBRE O PROJETO NA UNIDADE ACADÊMICA?

( X)SIM ( )NÃO

JUSTIFIQUE

A GESTÃO PARTICIPATIVA E DIALÓGICA PROMOVIDA PELA COORDENAÇÃO PERMITE UMA AMPLA DISCUSSÃO SOBRE TUDO O QUE ENVOLVE O PROJETO, FAZENDO COM QUE TODOS OS PARTICIPANTES SE SINTAM "DONOS" DELE, VERDADEIRAMENTE RESPONSÁVEIS PELO SEU ÊXITO.

HOUVE DIFICULDADE NO USO DO SISTEMA DE EXTENSÃO SIEX?

( ) SIM (X)NÃO

JUSTIFIQUE

HOUVE DIFICULDADE NA INTERLOCUÇÃO COM A EQUIPE DO DECANATO DE EXTENSÃO? ( )SIM (X)NÃO

ESPECIFIQUE

QUANTO A EXECUÇÃO DO PROJETO:

HOUVE APOIO DA UNNIDADE ACADÊMICA NO DESENVOLVIMENTO DO PROJETO?

( X)SIM INDIQUE EM QUE ASPECTO:

(X) INFRAESTRUTURA

( ) RECURSOS FINANCEIROS

( ) TRANSPORTE

(X) SERVIÇOS GRÁFICOS

( ) DIVULGAÇÃO CITE O INSTRUMENTO

( )RECURSOS HUMANOS

( )NÃO

(X) ASSESSORIA TÉCNICA ADMINISTRATIVA

QUANTO AO APOIO FINANCEIRO:

O PROJETO PARTICIPOU DE EDITAIS DE APOIO ÀS ATIVIDADES DE EXTENSÃO? 


\begin{tabular}{|l|l|}
\hline (X)SIM & INDIQUE QUAIS AS FONTES: \\
& ( X) EDITAL PIBEX/DEX \\
& ROTATIVIDADE DE USO DA BOLSA DE EXTENSÃO CONSIDERANDO DOZE MESES: \\
& (X) BAIXA (OITO MESES) \\
& ( ) MÉDIA (SEIS MESES) \\
& ( ) ALTA (TRÊS MESES) \\
& HOUVE DIFICULDADE NA GESTÃO DAS BOLSAS DE EXTENSÃO? \\
& ( )SIM (X)NÃO \\
& ESPECIFIQUE \\
\hline
\end{tabular}

( ) EDITAL DE FOMENTO/DEX

HOUVE DIFICULDADE NA GESTÃO DOS RECURSOS FINANCEIROS CONCEDIDOS? ( )SIM ( )NÃO ESPECIFIQUE

( ) EDITAL PROEXT/MEC

HOUVE DIFICULDADE NA GESTÃO DOS RECURSOS FINANCEIROS CONCEDIDOS?

( )SIM ( )NÃO

ESPECIFIQUE

( ) NÃO

OUTRAS FONTES DE APOIO FINANCEIRO

ESPECIFIQUE

O PROJETO RECEBE APOIO FINANCEIRO DO INSTITUTO PRÓ-MEDIAÇÃO, INSTITUIÇÃO

SEM FINS LUCRATIVOS IDEALIZADORA DO PROJETO, E DE VOLUNTÁRIOS.

QUANTO ÀS PARCERIAS:

A CONTRAPARTIDA ESTABELECIDA PELOS PARCEIROS FOI EFETIVADA?

( X) SIM ( )NÃO

JUSTIFIQUE

O INSTITUTO PRÓ-MEDIAÇÃO ASSUME ALGUMAS DESPESAS DO PROJETO, COMO

TRANSPORTE, CERTIFICADOS, CAMISETAS, MATERIAL DIDÁTICO, DENTRE OUTROS.

VOLUNTÁRIOS TAMBÉM COLABORAM.

A CONTRAPARTIDA PREVISTA PELA UNB FOI EFETIVADA?

( X)SIM ( )NÃO

JUSTIFIQUE

A UNIVERSIDADE OFERECEU INFRAESTRUTURA, APOIO TÉCNICO-ADMINISTRATIVO E AS BOLSAS DOS EXTENSIONISTAS.

PRODUTOS GERADOS

O PROJETO JÁ DISPÕE DE PRODUTOS

(X) SIM ( )NÃO

ESPECIFIQUE

1 - PROJETO DE MEDIAÇÃO SOCIAL MODELO (METODOLOGIA PRÓPRIA) PARA

INSTITUICOÕES DE ENSINO DO DF E OUTROS ESTADOS. 2 - CARTILHA. 3 - CANAL DE COMUNICAÇÃO PRÓPRIO.

RELATE AS PRINCIPAIS DIFICULDADES E METAS ALCANÇADAS PELO PROJETO ATÉ O MOMENTO:

A PRINCIPAL DIFICULDADE DIZ RESPEITO AO ASPECTO FINANCEIRO, QUE IMPEDE O BOM ANDAMENTO E A MULTIPLICAÇÃO DO PROJETO. A DEMANDA É CRESCENTE, AGORA PARTINDO DE OUTROS ESTADOS DA FEDERAÇÃO, E A COORDENAÇÃO NÃO CONSEGUE CUSTEAR PASSAGENS E HOSPEDAGENS. OUTRA DIFICULDADE VEM DA DISPONIBILIDADE DE BOLSAS DE ESTUDOS PARA OS EXTENSIONISTAS, INSUFICIENTE PARA ATENDER A DEMANDA DAS ESCOLAS QUE PRETENDEM DESENVOLVER O 
PROJETO. CONTAR COM ESTUDANTES VOLUNTÁRIOS É DIFICIL, UMA VEZ QUE AS AÇÕES DO PROJETO SÃO REALIZADAS FORA DA UNIVERSIDADE (ESCOLAS PÚBLICAS EM DIVERSAS REGIÕES), O QUE IMPLICA EM DESPESAS PESSOAIS PARA OS PARTICIPANTES.

DATA: 1 ASSINATURA/CARIMBO E MATRÍCULA DO COORDENADOR DO PEAC

11. ANUÊNCIA DO COORDENADOR DE EXTENSÃO DA UNIDADE ACADÊMICA

DATA: 